UNIVERSIDADE DE BRASÍLIA - UnB

INSTITUTO DE GEOCIÊNCIAS - IG

DEPARTAMENTO DE GEOLOGIA

\title{
AMÁLGAMAS DO W-GONDWANA NA PROVÍNCIA TOCANTINS
}

Antonio Augusto Soares Frasca

Tese de Doutorado $\mathrm{N}^{0} 123$

Orientador: Prof. Dr. Elton Luiz Dantas

Co-orientador: Prof. Dr. Reinhardt Adolfo Fuck

Brasília, DF

Junho, 2015

Antonio Augusto Soares Frasca 


\title{
AMÁLGAMAS DO W-GONDWANA NA PROVÍNCIA TOCANTINS
}

\author{
Banca Examinadora:
}

Prof. Dr. Elton Luiz Dantas (orientador) Prof. Dr. Massimo Matteini (UnB)

Prof. Dr. Nilson Francisquini Botelho (UnB) Prof $^{\mathrm{a}}$. Dr ${ }^{\mathrm{a}}$. Mônica da Costa Pereira Lavalle Heilbron (UERJ) Prof. Dr. Ricardo Ivan Ferreira da Trindade (USP) 
"Igitur qui desiderat pacem, praeparet bellum”.

De Re Militari - Livro três, prefácio. Publius Flavius Vegetius Renatus - Sec. IV-V D

"Alea jacta est" Gaius Iulius Caesar 49 a.C. 


\section{NOTA \& AGRADECIMENTOS}

Após anos de uma árdua batalha, travada em todos os âmbitos. Profissional, Acadêmico e Pessoal, poderia chegar neste momento, como é de praxe a todos, e oferecer dezenas de passagens a gratificar...

Mas, a realidade foi outra, apesar de ótimos momentos, há poucas pessoas que fazem jus a este destaque. Aos que lerão estes textos e sem conhecer os acontecimentos, de seu inicio, ao fim, pode passar a ideia de presunção, garanto-lhes que não é o caso, e aos que sabem dos fatos de que abordo certamente me darão a causa...

No final de 2009, retornando da área, onde esta tese foi desenvolvida, fomos a Laboratório de Estudos Geodinâmicos e Ambientais do Instituto de Geociências da UnB e graças a esta visita, tudo começou...Dedico, então meu primeiro reconhecimento:

Ao orientador Prof. Dr. Elton Luiz Dantas, pelo convite, a firme amizade e apoio incondicional oferecido em todos estes anos. Ao Prof. Dr. Reinhardt Adolfo Fuck, por seu acolhimento, boa vontade e voluntariosa e ferrenha disposição. A ambos os amigos, pelo debate técnico, discussão, nem sempre convergentes, mas de importância vital ao despertar de ideias. Agradeço e fico em dívida...

Aos professores deste Instituto que nos cederam seu tempo, ministrando aulas em cursos condensados e por partilhar de seu conhecimento: Em nome de: Dr.Nilson Francischini Botelho, Dr. Valmir da Silva Souza, Dr. Claudinei Gouveia de Oliveira, Dr. Farid Chemale Jr., Dr. Massimo Matteini, Dr. Bernhard Bühn, Dra. Caroline Thais Martinho agradeço a todo o corpo docente do Instituto de Geociências da UnB.

Aos amigos desta jornada: Joffre Valmório de Lacerda Filho, que foi a pessoa que desde inicio ao término deste trabalho, lutou duramente, lado a lado, este desafio e em todos os seus momentos. Diga-se não foram poucos e na maioria exaustivos, e é claro por sua eterna paciência, ao meu gê nio... Ao amigo Jaime Estevão Scandolara, a quem agradeço pela presteza, ao partilhar ideias e ao seu vasto conhecimento geológico e apoio. A ambos fica meu reconhecimento e amizade.

Aos colegas de trabalho da CPRM - Superintendência Regional de Goiânia que francamente colaboraram e pelo apoio dado. Obrigado.

Para minha Familia e Filhos. Por minha falta física neste período e por meu reconhecido e rusguento temperamento, vulcânico e ácido, minhas sinceras desculpas e gratidão.

Finalmente, a minha Mãe. A pessoa de maior importância na minha formação, sob todos os aspectos temporais e físicos de minha vida. A Prof.(a). Zilah Soares Frasca, uma mulher de imensa fé, sustentáculo que lutou quase na abnegação a vida toda, pela educação e principalmente, à união de sua família, batalhadora, até seu último suspiro, ao qual ... marco aqui o amor e a gratidão eterna de seu filho... 


\section{ÍNDICE}

Índice de Figuras -

Pag.

Índice de Tabelas -

Resumo -

Abstract -

Capítulo 1- Introdução -

1.1 - Objetivo -

1.2 - Materiais e Métodos -

Capítulo 2 - O Neoproterozóico - Questões Globais -

2.1 - Introdução - Tectônica de Placas - $\quad 17$

2.2 - Supercontinentes - $\quad 19$

2.3 - Neoproterozóico no Mundo - De Rodínia a Gondwana. - 24

2.4 O Neoproterozóico na América do Sul e as

Conexões com Provincias Estruturais Cronocorrelatas -

Capítulo 3- Contexto Geológico Regional -

3.1 - Orógeno Brasília - $\quad 37$

3.2 - Orógeno Araguaia - $\quad 42$

3.3 - Orógeno Paraguai - $\quad 43$

Capítulo 4 - Geologia Estrutural 446

4.1 - Introdução

4.1.1 Sistema de Falhas Transbrasilianas 46

4.1.2 Sistema Compressional Xambioá-Gurupi $\quad 48$

4.1.3 Sistema Transpressional Rio Maranhão-Paranã 49

4.1.4 Falha do Rio dos Bois $\quad 50$

4.2 Análise de Sensores Remotos 50

4.3 - Análise Estrutural $\quad 51$

4.3.1 - Domínio Dúctil do Embasamento (Infraestrutura) 53

4.3.2 - Domínio Dúctil Compressional Centro-Leste 58

4.3.3 - Domínio Dúctil Compressional -Transpressional Oeste 60

4.3.4 - Domínio Dúctil Transcorrente Central 64

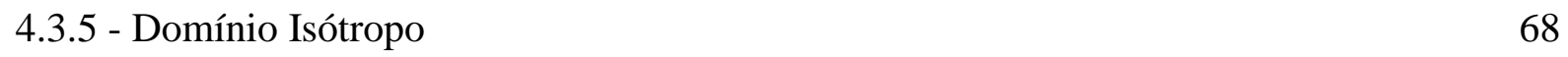

4.3.6 - Domínio Rúptil 69

Capítulo 5 - Arcos Acrescionários e Sistemas de Falhas Direcionais: O Caso do Arco Magmático de Goiás, Neoproterozóico, Brasil-Central.

$\begin{array}{ll}\text { Resumo - } & 71\end{array}$

$\begin{array}{ll}5.1 \text { - Introdução - } & 71\end{array}$

5.2 - Geologia Regional e Tectônica - 
5.3 - Procedimentos Analíticos - $\quad 80$

Resultados - $\quad 81$

5.4 - Geologia e Geocronologia - $\quad 81$

5.4.1 - Embasamento - $\quad 83$

5.4.2 - Arcos Neoproterozóicos -

5.5 - Dados Geoquímicos, Ambiente Geotectônico e Isótopos de Sm-Nd - 94

5.5.1 - Embasamento - $\quad 94$

5.5.2 - Arcos Neoproterozóicos -

5.6 - Discussão -

5.6.1 - Arco Magmatismo - 105

5.6.2 - Tectônica Strike slip e Estágios Magmáticos - 107

5.6.3 - Zonas de Sutura, Transpressão e Granulitos - O Papel do LTB 107

5.6.4 - Implicação Global e Regional - 111

5.7 - Conclusão - $\quad 112$

Capítulo 6 - Evidências de Magmatismo Adakítico no Arco Magmático de Goiás, Orógeno Brasília Setentrional (Brasil), W-Gondwana

Resumo 116

6.1- Introdução -

6.2 - Estruturação Geológica - $\quad 118$

6.2.1 - O Orógeno Brasília - $\quad 119$

6.3 - Ocorrência e Petrografia - 123

6.4 - Métodos Analíticos - $\quad 127$

Resultados - $\quad 129$

6.5 - U-Pb Zircão e Saturação de Zircão - $\quad 129$

6.6-Geoquímica - 131

6.6.1. -Geoquímica de Elementos Maiores e Traço - "Adakitos Tipo I " 131

6.6.2. Classificação Geoquímica - Elementos Maiores e Traço - "Adakitos Tipo II” 133

6.6.3 - Geoquímica Isotópica Sm-Nd -

6.6.4 - Ambiente Tectônico - 137

6.7 - Discussão - $\quad 139$

6.7.1 - Aspectos Petrogenéticos -

6.7.2 - Natureza da Região de Fonte dos Magmas Adakiticos - $\quad 143$

6.7.3 - Significado Tectônico - $\quad 144$

6.8 - Conclusão - 147

7 - Conclusão - $\quad 149$

8 - Referências - $\quad 153$

\section{Anexo I}

Tabelas de dados U-Pb 


\section{ÍNDICE DE FIGURAS}

Pag.

\section{Capítulo 1}

Fig. 1.1 - Localização da área da tese no sul do estado de Tocantins e norte de Goiás.

\section{Capítulo 2}

Fig. 2.1 - Concepção de Maruyama et al., (2007) para a fragmentação continental, formação de oceanos e ocorrência de microplacas.

Fig. 2.2 - Concepção da estrutura térmica da Terra Maruyama et al., (2007).

Fig. 2.3 - A força motriz para a dinâmica do manto, Maruyama et al., (2007).

Fig. 2.4 - Evolução Geológica do Neoproterozóico desde $1.1 \mathrm{Ga}$ a $0.53 \mathrm{Ga}$ Li et al., (2008). 29

Fig. 2.5- Esquema de quebra de Rodínia, amalgamação e formação de Gondwana.

Fig. 2.6 - Mapa geológico da "Plataforma Sul-americana", Cordani et al. (2000).

\section{Capítulo 3}

Fig. 3.1 - Esboço da compartimentação tectônica

Porção centro-leste Província Tocantins.

\section{Capítulo 4}

Figura 4.1 - Imagem Gravimétrica da América do Sul, contexto estrutural e influência

do Lineamento Transbrasiliano.

Figura 4.2 - Imagem aerogeofísica com a amplitude de sinal analítico

Figura 4.3 - A) Aspecto de bandamento relíquiar transposto em alto ângulo; B) Detalhe

de bandamento dobrado e transposto em granodiorito gnaisse; C) inicio

processo gnaissificação; D) Aspecto de bandamento gnáissico dobrado em tonalitos

Figura 4.4- A) Aspecto de bandamento relíquiar transposto em alto ângulo em paragnaisses;

B) inicio processo gnaissificação; C) Detalhe em planta de bandamento dobrado com aspecto migmatitico; D) Aspecto de bandamento gnáissico dobrado em tonalitos $\quad 56$

Figura 4.5 -Estereogramas do Domínio Dúctil do Embasamento 56

Figura 4.6- A Aspecto em planta de foliação milonítica da

fase de transcorrência do embasamento

Figura 4.7 - Bloco diagrama com a composição dos afloramentos Domínio Dúctil

do Embasamento

Figura 4.8 - Estereograma domínio dúctil compressional

Figura 4.9) A- Aspecto regional de limbo de flanco de dobras no Grupo Serra;

$\mathrm{B}$ e C- aspecto de dobras apertadas

Figura 4.10- Domínio Compressional - Transpressional A) Aspecto da foliação de baixo ângulo B)

Detalhe de foliação de baixo ângulo no embasamento da Orógeno Araguaia;

C e D) corpos estratóides intrusivos, marcando a deformação de baixo ângulo

Figura 4.11) A - Estereograma das superfícies foliação milonítica e xistosidades de baixo

ângulo domínio dúctil compressional a transpressional

Figura 4.12)- Arranjo dos afloramentos com fotos e sketchs de campo dúctil

Domínio compressional a transpressional.

Figura 4.13A e B - Feição de dobras de cisalhamento assimétricas do domínio transcorrente; Vista lateral das bandas de cisalhamento $\mathrm{N} 50^{0} \mathrm{E} 40^{\circ} \mathrm{NW}$, transpondo foliação anterior e planos de cisalhamento preenchidos por quartzo. 
Figura 4.14 A e B - Porfiroclastos de feldspato alcalino assimétricos 66

Figura 4.15 - Estereograma domínio domínio transcorrente 67

Figura 4.16 - Esboço do domínio transcorrente transtracional. $\quad 68$

Figura 4.17 - Estereograma com as superfícies das falhas e fraturas 69

\section{Capítulo 5}

Fig. 5.1 - Contexto geológico regional da Província Tocantins, 75 orógenos Brasília e Araguaia.

Fig. 5.2 - Imagem aeromagnetométrica da amplitude do sinal analítico 79 e descontinuidades magnéticas.

Fig. 5.3 - Esboço geológico local e principais segmentos geotectônicos. 82

Fig. 5.4 - Gnaisses tonaliticos e granodioriticos do Embasamento e idades U-Pb em zircão $\quad 85$

Fig. 5.5 - Rochas do estágio de arco intra-oceânico. Aspecto macro e fotomicrografias. $\quad 86$

Fig. 5.6 - Diagramas concórdia das rochas do estágio de acresção intra-oceânica. $\quad 86$

Fig. 5.7 - Padrões de afloramento e fotomicrografias do estágio de colisão arco-continente. $\quad 87$

Fig. 5.8 - Padrões de afloramento e fotomicrografias do estágio colisional a pós-colisional. 89

Fig. 5.9 - Aspecto microscópico dos ortogranulitos. 90

Fig. 5.10 - Diagramas concórdia das rochas do estágio de acresção colisional a pós-colisional. 90

Fig. 5.11 - Diagramas concórdia com as idades de cristalização. 91 do estágio de maturidade do arco.

Fig. 5.12 - Lineamentos estruturais, estereogramas e foliações de domínios estruturais. 93

Fig. 5.13 - Diagramas ETR e spidergramas do arco intra-oceânico. e estágios magmáticos do arco continental. 99

Fig. 5.14 - Diagramas AFM modificado e diagrama ternário $\mathrm{Na}_{2} \mathrm{O}-\mathrm{K}_{2} \mathrm{O}-\mathrm{CaO}$.

Fig. 5.15 - Gráficos de ambientes tectônicos e diagrama $\mathrm{Na}_{2} \mathrm{O}-\mathrm{K}_{2} \mathrm{O}-\mathrm{CaO}$ x SiO 2.

Fig. 5.16 - Distribuição das idades $\mathrm{T}_{\mathrm{DM}}$ ao longo do LTB. 104

Fig. 5.17 - Diagramas de evolução isotópica de Nd. 105

Fig. 5.18-Modelo de evolução geológica. 110

\section{Capítulo 6}

Fig. 6.1 - Contexto geológico regional da Província Tocantins. 120

Segmento setentrional dos Orógenos Brasília e Araguaia.

Fig.6.2 - Esboço geológico da área.

$\begin{array}{ll}\text { Fig. } 6.3 \text { - Esboço geológico da área secundária de estudo em Goiás. } & 125 \\ \text { Fig. 6.4 - Lâminas delgadas de tonalitos e granodioritos “Tipo" adakiticos. } & 127\end{array}$

Fig. 6.5 - Diagramas concórdia dos adakitos. 130

Fig. 6.6 - Diagrama de pressão e temperatura Vs. equilíbrio de fases 131

Fig. 6.7 - Classificação e curvas de elementos traço e ETR, Diagramas AFM,

$\begin{array}{ll}\text { Índice de Shand; spidergramas. } & 135\end{array}$

Fig. 6.8 - Diagramas indicativos de fracionamento mineral. 136

Fig. 6.9 - Diagramas de distinção de rochas adakiticas $(\mathrm{La} / \mathrm{Yb})_{\mathrm{n}}$ vs. $\mathrm{Yb}_{\mathrm{n}}$, e Sr/Y vs Y. 136

Fig. 6.10 - Diagrama de evolução isotópica Nd. 138

Fig. 6.11 - Diagrama R1-R2. 139

Fig. 6.12.- Gráfico \#Mg vs $\mathrm{SiO}_{2}$; gráfico $\mathrm{Nb} / \mathrm{Ta}$ vs $\mathrm{Zr} / \mathrm{Sm}$. 141

Fig. 6.13 - Diagrama índice de $\mathrm{La} / \mathrm{Yb}$ vs. Yb normalizado ao condrito.

Diagrama $\mathrm{Sr} / \mathrm{Y}$ vs. La/Yb: gráfico $\mathrm{Sr} / \mathrm{Y}$.

Fig. 6.14 - Diagramas Th/U vs. U e(b) Th/U versus Th; Diagrama $\mathrm{MgO}$ vs. $\mathrm{SiO}_{2}$;

Diagrama $\mathrm{Al}_{2} \mathrm{O}_{3} / \mathrm{FeO}+\mathrm{MgO}+\mathrm{TiO}_{2}$ vs. $\mathrm{Al}_{2} \mathrm{O}_{3} /+\mathrm{FeO}+\mathrm{MgO}+\mathrm{TiO}_{2}$ 
Fig. 6.15 - Modelo para geração dos adakitos no estágio pós-colisional.

ÍNDICE DE TABELAS

\section{Capítulo 1}

Tabela 1.1 - Dados de produção e dados utilizados no trabalho.

\section{Capítulo 5}

Tabela 5.1 - Resultado da análise química das rochas de embasamento.

Tabela 5.2 - Resultado da análise química das rochas dos arcos neoproterozóicos por estágios tectônicos.

Tabela 5.3 - Composição isotópica de Sm-Nd do embasamento e

Arco Magmático de Goiás e seus estágios tectônicos.

\section{Capítulo 6}

Tabela 6.1 - Composição modal dos adakitos, classificação e da mineralogia principal e acessória.

Tabela 6.2 - Cálculo de saturação de zircão.

Tabela 6.3 - Análises químicas das rochas de tendência adakítica no AMG e intrusivas no embasamento.

Tabela 6.4 - Principais características químicas de rochas adakiticas e referências. 


\section{Resumo}

Os orógenos Brasília e Araguaia são cinturões Neoproterozoicos da Província Tocantins. Desenvolveram-se durante a amálgama do W-Gondwana, como consequência da colisão e colagem de blocos alóctones, arcos acrescionários e sequências metavulcanossedimentares correlatas entre os crátons Amazônico e São Francisco-Congo. Na porção setentrional do Orógeno Brasília rochas plutônicas calcialcalinas de arco magmático se estendem por mais de $250 \mathrm{~km}$ e constituem a extensão do Arco Magmático de Goiás (AMG). Apresentam na área estudada características estruturais diversas dos setores de arco ao sul. A distribuição das rochas de arco e embasamento estão controladas pelo Lineamento Transbrasiliano (LTB) que constitui peça fundamental na macroestruturação regional. O LTB deforma e baliza arcos magmáticos distintos entre os blocos de embasamento, ao passo que lascas da infracrosta se inserem nos arcos, formando uma rede intrincada de blocos com caraterísticas químicas e isotópicas díspares. Todos estes elementos tectônicos em conjunto compõem por definição um complexo orogênico. Para identificação dos diversos segmentos e eventos tectônicos realizou-se mapeamento, litoquimica, datação $\mathrm{U}-\mathrm{Pb}$ e isótopos de $\mathrm{Nd}$ em um grupo especifico de tonalitos e granodioritos principalmente. Os resultados definiram: Um embasamento que representa o segmento de infra- mesocrosta com fontes arqueanas e paleoproterozóicas. Determinações $\mathrm{U}-\mathrm{Pb}$ indicam idades de $2142+11$ a $2083+18$ Ma para rochas ígneas, mas apresentam intervalos de $T_{D M}$ mais longos de 2980 Ma a 1500 Ma com fontes de $\varepsilon_{N d}$ mistas sugestivas de contribuição juvenil e de derivação crustal. Há no mínimo dois arcos neoproterozóicos sobrepostos neste espaço. O primeiro com características litoquímicas de arco insular, sem participação de crosta antiga e é correlacionado à Acrescão de Mara Rosa, de idades U-Pb entre $848 \pm 4$ Ma a $810 \pm 4 \mathrm{Ma}, T_{D M}$ entre 1480 e 910 Ma e $\varepsilon_{N d(T 840)}$ com valores de $+1.56 a+5.14$, sugerindo fontes juvenis. Um segundo evento magmático mais jovem é reconhecido. É formado por magmatismo calci-alcalino associado a uma margem continental ativa e nomeado de Santa Terezinha de Goiás. São identificados em três estágios evolutivos, arco-continente (transicional), colisional a póscolisional e maturo. $O$ estágio arco-continente possui fontes mistas e heterogêneas, parte reciclagem crustal, parte juvenil com $T_{D M}$ desde 2610 a $960 \mathrm{Ma}$, e em torno de $1.2 \mathrm{Ga}$, $\varepsilon_{N d}$ de $-25.44 a+6.13$. O Estágio colisional representa a maturidade química do arco. Possui valores elevados LILE e HFSE com anomalias positivas em $\mathrm{Th}, \mathrm{La}, \mathrm{K}$ e $\mathrm{Zr}$ e depletações em $\mathrm{Ba}, \mathrm{Nb}, \mathrm{P}$ e Ti, padrões assimétricos e enriquecidos em ETRL, depletados em ETRP com anomalias negativas de Eu. Determinações U-Pb em zircão indicam idades de 594+2 Ma, 586+3 Ma e 540+5 Ma e zircões herdados do arco insular com

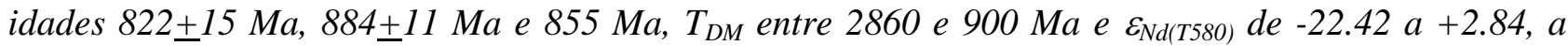
grande maioria negativa indicando retrabalhamento crustal com pouca contribuição juvenil. Rochas de tendência adakitica ocorrem associadas a este estágio. São tipo $\mathrm{HSA}$ (Alta $\mathrm{SiO}_{2}$ ), alto $\mathrm{Na}_{2} \mathrm{O}>4 \%$, baixas razões $\mathrm{K}_{2} \mathrm{O} / \mathrm{Na}_{2} \mathrm{O}<0.5$, curvas de ETR muito fracionadas, sem anomalias de Eu, alto $\mathrm{Sr}$ (>631 ppm), baixo $\mathrm{MgO} \%$ (<1.8, baixo), $Y(<13 \mathrm{ppm}$ ), alta razão $\mathrm{Sr} / \mathrm{Y}>30$ e $>50$ (média), $\mathrm{Yb}(<1.13 \mathrm{ppm}$ ), alta razão $\mathrm{La} / \mathrm{Yb}(>45)$ e (La)n/(Yb)n (>30), baixo HFSE, como Nb<8 ppm (média), Ta<0.5 ppm (média). Possuem idades modelo heterogeneas as mais jovens entre 0.97 e $0.96 \mathrm{Ga}$ com $\varepsilon_{N d}\left(T_{0.58}\right)$ entre -0.60 e -0.95, indicando participação de material de derivação crustal. Determinações $U-P b$ em zircão apontam idades entre 590-540 Ma. A interpretação petrogenética sugere uma fusão primária parcial abaixo de 5\% na base da crosta máfica continental entre o campo rutilo eclogito $e$ anfibolitohornblenda eclogito com anfibólio-Cpx-granada-plagioclásio no resíduo. Os adakitos mais jovens indicam um contexto pós-colisional com produtos de fusão derivados de delaminação da crosta inferior. $O$ estágio maduro apresenta padrões com maior enriquecimento em HFSE e ETRL do que em LILE. As idades de cristalização são próximas a 540 Ma. Rochas básicas pós-orogênicas analisadas apresentam fontes crustais e juvenis e $T_{D M}$ entre 1490 e $820 \mathrm{Ma}$, com $\varepsilon_{N d(T 530)}$.de -1.11 a +4.26 . O LTB insere um complexo orogênico na porção setentrional do Orógeno Brasília constituindo uma intensa zona de cisalhamento transcontinental transcorrente e uma sutura crustal limitando diversos blocos com uma geometria de "pop up", que amálgama os sistemas de arcos e o embasamento no W-Gondwana. 


\section{Abstract}

The Brasilia and Araguaia orogens are Neoproterozoic belts of the Tocantins Province, developed during the amalgamation of the W-Gondwana, as a result of a collision involving allocthonous blocks, accretionary arcs and related metavolcanosedimentary sequences between the Amazon and San Francisco-Congo cratons. In the northern portion of the Brasilia Orogen calc-alkaline plutonic rocks of magmatic arc extend over $250 \mathrm{~km}$ and is the extension of the Goiás Magmatic Arc (AMG). The study area show different structural characteristics from south arc sectors. The distribution of arc rocks and basement are controlled by the Transbrasilian Lineament (LTB) that is a key element in the regional structure. The LTB deform and keep distinctive magmatic arcs between basements, while infracrustal wedges are inserted in the arcs, and form an intricate network of blocks with a broad range of chemical and isotopic characteristics. All these tectonic elements comprise an orogenic complex. The various segments and tectonic events were identified using geological mapping, litochemical analyses, $U-P b$ dating and $N d$ isotopes in a specific group of tonalite and granodiorite rocks mainly. The results defined: An early basement with Archean and Paleoproterozoic sources. U-Pb dating indicates ages $2142 \pm 11$ to $2083 \pm 18$ Ma for igneous rocks, but have large broader TDM intervals: $2980 \mathrm{Ma}$ to $1500 \mathrm{Ma}$, with mixed $\varepsilon_{N d}$ sources suggestive of juvenile contribution and crustal reworking. There are at least two Neoproterozoic arcs overlapping in this space. The first with chemical characteristics of island arc, without participation of ancient crust and correlated with Mara Rosa accretion. The rocks presents $U$-Pb ages between $848 \pm 4 M a$ to $810 \pm 4 M a$, TDM between 1480 and 910 Ma and $\varepsilon_{N d(T 840)}+5.14$ to +1.56 , suggesting juvenile sources. A second group of arc is recognize and is the youngest magmatic event. It consists of a calc-alkaline magmatism of the active continental margin type named Santa Terezinha de Goiás. In continental arc is identified three stages: arc-continent (transitional), collisional to post-collisional and mature. The arc-continent stage has mixed and heterogeneous sources, recycled crust and juvenile portion with $T_{D M}$ from 2610 to $960 \mathrm{Ma}$, and average around $1.2 \mathrm{Ga}$ with $\mathrm{ENd}$ from -25.44 to +6.13. The collisional stage is the chemical maturity of the arc. It has high values of LILE and HFSE with positive anomalies of $\mathrm{Th}, \mathrm{La}, \mathrm{K}$ and $\mathrm{Zr}$, depleted in $\mathrm{Ba}, \mathrm{Nb}, \mathrm{P}$ and Ti, asymmetrical patterns and LREE enriched, depleted in HREE with negative anomalies of Eu. U-Pb dating in zircon indicate $594 \pm 2 \mathrm{Ma}, 586 \pm 3$

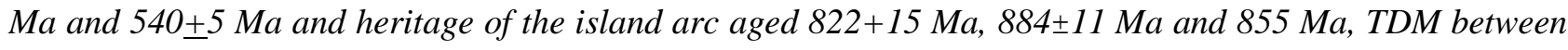
2860 and $900 \mathrm{Ma}$ and $\varepsilon_{\mathrm{Nd}(T 580)}$ of -22.42 to +2.84 , the most negative resultindicating crust reworking with some juvenile contribution. Chemical evidences of Adakites like occur associated with the latest collisional stage. characterized by adakites like $\mathrm{HSA}$ (High SiO2), high $\mathrm{Na} 2 \mathrm{O}>4 \%$, lower ratios $\mathrm{K} 2 \mathrm{O} / \mathrm{Na} 2 \mathrm{O}<0.5$, very fractionated REE curves without Eu anomalies, high $\mathrm{Sr}$ (> $631 \mathrm{ppm})$, low $\mathrm{MgO} \%(<1.8$, below) , Y (<13 ppm), high ratio $\mathrm{Sr} Y>30$ and 50 (average), $\mathrm{Yb}(<1.13 \mathrm{ppm}$ ), high ratio La/Yb (> 45) and $(\mathrm{La}) n /(\mathrm{Yb}) n$ (>30), low HFSE such as $\mathrm{Nb}<8 \mathrm{ppm}$ (average), Ta $<0.5 \mathrm{ppm}$ (average). Moreover present heterogeneous model ages between 0.97 and younger $0.96 \mathrm{Ma}$ with $\varepsilon_{N d}$ (T0.58) between -0.60 and -0.95 signatures, indicating involvement of crustal derivation material. Determinations $U$-Pb in zircon indicate ages of 590-554 Ma. The petrogenetic interpretation suggests a partial primary melting below 5\% at the base of the continental mafic crust between rutile eclogite and amphibolite field-hornblende amphibole eclogite with-Cpx-garnetplagioclase in the residue. Younger like adakites indicate a post-collision context, fusion products derived from the delamination of the lower crust. The mature stage shows patterns with LREE and HFSE enrichment than LILE. The crystallization ages are close to $545 \mathrm{Ma}$. Analyzed post-orogenic crustal basic rocks present and juvenile sources, TDM between 1490 and $820 \mathrm{Ma}$, with $\varepsilon N d$ (T530) $-1.11 /+4.26$. The LTB is responsible for the insertion of orogenic complex in the northern portion of the Brasilia Orogen constituting an intense zone of strike-slip shear transcontinental and a crustal suture limiting several blocks with a pop up geometry, which amalgamates the arc systems and basement in W-Gondwana. 


\section{Capítulo 1- Introdução}

Investigações geológicas no inicio de 2000, incluindo mapeamento sistemático na escala 1:250.000 das folhas Gurupi (SC.22-Z-D), Alvorada (SD.22-X-B), 1:100.000 folha Bonópolis (SD.22-X-C-VI) foram desenvolvidas no extremo sul e sudeste do estado de Tocantins e norte de Goiás.

A pesquisa e o mapeamento realizados na área da Província Tocantins responderam algumas e suscitaram outras questões de cunho geológico que há muito tem sido objeto de estudos do Instituto de Geociências da Universidade de Brasília (UnB) e do Serviço Geológico do Brasil (CPRM). Grande parte do estudo teve o intuito de sanar a lacuna de informações geológicas existentes na porção limítrofe dos Orógenos Brasília e Araguaia.

Nesse contexto, várias questões foram erguidas sobre o prosseguimento do compartimento geotectônico do Arco Magmático de Goiás, para além do estado de Goiás, o entendimento deste elemento, no sentido de expandir sua ocorrência e agregar dados a sua gênese, fonte e idade, geometria e estruturação, bem como a continuidade cartográfica de seus elementos são o alvo da presente tese em geologia regional, para a arquitetura geológica e compreensão da dissolução do paleocontinente Rodínia e colagem de West Gondwana no Neoproterozóico. Acrescenta- se que a áreaalvo selecionada como proposta de estudo possui levantamentos geológicos em escala compatível com a pesquisa.

Outra questão que justifica a presente tese é a plêiade de dados, levantados desde 1996, por vários projetos de mapeamento. Estas informações associadas a imagens aerogeofísicas, além de mais dados litogeoquímicos ICP-MS, isotopos de $\mathrm{Sm}-\mathrm{Nd}$ e U-Pb, centenas de afloramentos e dados estruturais já realizados compreendem o escopo deste estudo.

A área principal situa-se na porção centro-sul do Estado de Tocantins compreendida entre os paralelos $11^{\circ} 00$ e $13^{\circ} 00$ sul e os meridianos $48^{\circ} 00^{\prime}$ e $49^{\circ} 30$ a oeste de Greenwich, abrangendo uma área de aproximadamente duas folhas 1:250.000 com $36.000 \mathrm{~km}^{2}$, (Fig.1.1). Os alvos de estudo compreendem uma região de $10.000 \mathrm{~km}^{2}$ a $12.000 \mathrm{~km}^{2}$ e distribuem-se em uma faixa com cerca de $300 \mathrm{~km}$ de extensão por $80 \mathrm{~km}$ em média de largura. Uma segunda área de $3000 \mathrm{~km}^{2}$ em Goiás foi também adicionada.

\section{1-Objetivo}

A tese é apresentada na forma de dois artigos de cunho geotectônico em escala regional, baseados em dados analiticos geoquímicos e geocronológicos utilizando mapas levantados na escala 1:250.000 e 1:100.000. Nas unidades geológicas mapeadas pretende-se integrá-las, no sentido geo- 
tectônico e melhorar seus limites cartográficos, datá-las de forma mais extensiva pelos métodos Sm$\mathrm{Nd}$ e U-Pb. Em detalhe as finalidades são:

A) Artigo 1 é descrito no capítulo 5: Arcos Acrescionários e Sistemas de Falhas Direcionais: O Caso do Arco Magmático de Goiás, Neoproterozóico, Brasil-Central. Este artigo demonstrará a continuidade do Arco Magmático de Goiás, proposta por Pimentel e Fuck (1992), Pimentel et al., (1997), Fuck et.al., (2001), desde a região de Mara Rosa - Porangatu, até seu limite norte no Estado de Tocantins, em particular, até a área que Costa (1985) havia descrito como um embasamento arqueano. Relacionará este compartimento geotectônico a idades neoproterozóicas e sua formação no West Gondwana. As rochas distribuem-se em uma faixa de direção nordeste por milhares de $\mathrm{km}^{2}$, parcialmente expostas na porção centro-leste da folha Gurupi e prolongam-se para sul na folha Alvorada por dezenas de quilômetros, até o estado de Goiás.



Fig. 1.1 - Localização da área da tese no sul do estado de Tocantins.

Entender quantos arcos estão presentes na área, o magmatismo e evolução tectônica, as idades e distribuição relacionando-os a ocorrência à estruturação geral com o Lineamento Transbrasiliano, se possível, suas relações, arquitetura, e propostas evolutivas às suas principais feições estruturais são os temas a desenvolver. Utilizar-se-á para a tarefa, o conhecimento “in loco” da área e a 
descrição de centenas de afloramentos e imagens geofísicas.

B) Artigo 2- Capítulo 6: - Evidências de Magmatismo Adakítico no Arco Magmático de Goiás, Orógeno Brasília Setentrional (Brasil), W-Gondwana. Visa identificar padrões magmáticos atípicos, como a presença de rochas tipo adakitos na região e entendê-los em detalhe, utilizando-se de dados químicos, classificando origem e formação. Datar tais ocorrências e a partir de dados isotópicos $\mathrm{Sm}-\mathrm{Nd}$ e U-Pb posicioná-los no tempo e no espaço, sugerindo caso possível, novos modelos ou novas etapas à formação do Arco Magmático de Goiás em sua porção setentrional fazendo o link a formação de W-Gondwana.

\section{2 - Materiais e Métodos}

O método utilizado segue a sistemática estabelecida no guia de procedimentos técnicos adotado pela CPRM - Serviço Geológico do Brasil, para elaboração de mapeamentos geológicos e confecção de mapas na escala 1:250.000. Este compreende três fases principais:

A fase inicial consta de uma compilação e integração das informações geológicas disponíveis associando a elaboração de mapas preliminares e de serviço estruturados em SIG, interpretação de sensores remotos, aerogeofísicos, elaboração de mapas de integração, dados geológicos, geoquímicos e geocronológicos.

$\mathrm{Na}$ fase principal realizam-se as etapas de campo, descrição de afloramentos, coleta de material para análises petrográficas, petroquímicas (elementos maiores, traço e terras raras) e geocronológicas, seleção de alvos em afloramentos chave pré-determinados. Grande parte destes dados levantados envolve as operações diretas de campo, onde foram executados perfis e caminhamentos, percorridos $7993 \mathrm{~km}$ lineares mapeados e 868 afloramentos descritos. Destes para foco desta tese foram selecionados em detalhe 104 afloramentos. Dados de produção expostos na tabela 1.1.

A terceira etapa chamada fase final, consiste nas atividades pós-campo e envolve, fundamentalmente, a integração dos dados obtidos, interpretações temáticas em função dos resultados analíticos disponíveis, elaboração, digitação, digitalização, revisão e compatibilização de texto explicativo e figuras. A fase final compreendeu a consolidação de todas as informações para elaboração da tese e preenchimento do banco de dados.

Foram também realizadas 42 análises químicas realizadas no laboratório ACME. Os elementos maiores: $\mathrm{SiO}_{2}, \mathrm{TiO}_{2}, \mathrm{Al}_{2} \mathrm{O}_{3}, \mathrm{Fe}_{2} \mathrm{O}_{3}, \mathrm{MnO}, \mathrm{MgO}, \mathrm{CaO}, \mathrm{Na}_{2} \mathrm{O}, \mathrm{K}_{2} \mathrm{O}, \mathrm{P}_{2} \mathrm{O}_{5}$, LOI foram determinados por plasma de acoplamento indutivo (ICP), onde as amostras foram fundidas com 1.5 gramas de LiBO2e os traço: Ba, Be, Co, Cs, Ga, Hf, Nb, Rb, Sn, Sr, Ta, Th, U, V, W, Zr, Y e 14 ETR a determinação foi feita por um espectrômetro de massa com plasma de acoplamento indutivo (ICP MS), 
onde 1/5 gramas de amostra compostos com 1,4 gramas de LiBO2 num cadinho de grafite são fundidos a $1025^{\circ} \mathrm{C}$ por 25 minutos e em seguida dissolvidos em $\mathrm{HNO}_{3}$ a $5 \%$. A solução é diluída e então, aspirada por um espectrômetro de massa ICP (Perkin Elmer Elan 6000) para determinação da concentração dos elementos.

ATIVIDADE/FASE
Área do Projeto $\left(\mathrm{km}^{2}\right)$
Mapeamento Geológico $\left(\mathrm{km}^{2}\right)$
Caminhamento Geológico $(\mathrm{km})$
Afloramentos Descritos
Petrografia Analisada
Análise Litoquímica
Dados Estruturais
Imagens Aerogeofísicas $(500 \mathrm{mx} 500 \mathrm{~m}$
Espectroradiométricas e Magnetométricas
Geocronologia Sm-Nd*
Geocronologia U-Pb

Dados Totais
36.000
36.000
7993
868
477
233
1200
$36.000 \mathrm{Km}^{2}$
$303^{*}$
15

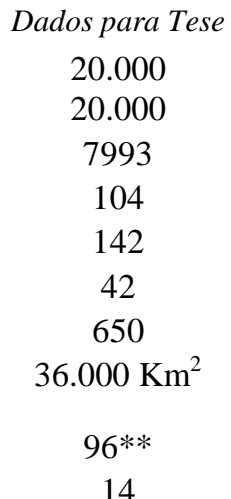

Tabela 1.1 - Dados de produção utilizados no trabalho.*Dados compilados e **dados executados neste trabalho.

Além das análises litoquímicas, um robusto acervo isotópico se fez necessário para comprovação de fontes e residência crustal, bem como a caracterização das idades de cristalização das rochas e terrenos envolvidos. Com este objetivo confeccionou-se um banco de dados com mais de 300 dados Sm-Nd da área e em torno desta e das quais 96 amostras estão inclusas na área de pesquisa.

Para as análises isotópicas foram utilizados os métodos descritos por Bühn et al., (2009) e Gioia \& Pimentel (2000). Neste procedimento cerca de $50 \mathrm{mg}$ de amostra pulverizada é misturada a uma solução traçadora de ${ }^{149} \mathrm{Sm}$ e ${ }^{150} \mathrm{Nd}$. A amostra é dissolvida em cápsulas Savillex ${ }^{\circledR}$ por meio de sucessivos ataques ácidos em $\mathrm{HF}, \mathrm{HNO}_{3}$ e $\mathrm{HCl}$. Os conteúdos de $\mathrm{Sm}$ e $\mathrm{Nd}$ são extraídos por meio de colunas de trocas catiônicas, confeccionadas em Teflon e preenchidas com resina LN-Spec. Os sais de Sm e Nd são depositados em filamentos de rênio com ácido nítrico e evaporados. As leituras das razões foram realizadas no espectrômetro de massas multicoletor, modelo Finnigan MAT 262 em modo estático. As incertezas para as razões de $\mathrm{Sm} / \mathrm{Nd} \mathrm{e} \mathrm{Nd}^{143} / \mathrm{Nd}^{144}$ são inferiores a $\pm 0.5 \%(2 \sigma)$ e $\pm 0.005 \%(2 \sigma)$, respectivamente, com base em repetidas análises nos padrões internacionais BHVO-1 e BCR-1. As razões $\mathrm{Nd}^{143} / \mathrm{Nd}^{144}$ foram normalizadas, em função da razão $\mathrm{Nd}^{146} / \mathrm{Nd}^{144} \mathrm{de}$ 0,7219. Os valores de $\mathrm{T}_{\mathrm{DM}}$ foram calculados usando o modelo de De Paolo (1981). Estas análises foram realizadas no laboratório de geocronologia da UnB.

Para a análise U-Pb os cristais de zircão foram concentrados conforme o procedimento padrão do Laboratório de Estudos Geodinâmicos e Ambientais da UnB, no qual a amostra é reduzida via britador e extraída à fração inferior a 500 micrômetros. 
A partir do material recolhido são concentrados os minerais pesados com uso de bateia. $\mathrm{O}$ concentrado é passado pelo separador isodinâmico Frantz e finalmente o zircão e/ou monazita são separados manualmente em lupa binocular. Os mounts foram confeccionados com resina epóxi (a frio), desgastados e polidos para exposição do interior dos grãos.

Para a limpeza dos mounts foi utilizado banho com ácido nítrico diluído (3\%), água Nanopure® em ultrassom e por último em acetona para extração de qualquer resíduo de umidade.

As análises isotópicas foram realizadas no LA-MC-ICP-MS Neptune (Thermo-Finnigan) acoplado ao Nd-YAG $(\lambda=213 \mathrm{~nm})$ Laser Ablation System (New Wave Research USA). A ablação dos grãos foi realizada em spots 25-40 micrômetros. O material pulverizado foi carreado por um fluxo de $\mathrm{He}(\sim 0.40 \mathrm{~L} / \mathrm{min})$ e $\operatorname{Ar}(\sim 0.90 \mathrm{~L} / \mathrm{min})$. Em todas as análises foi utilizado o padrão internacional GJ-1 e o padrão interno PAD-1.

Os dados foram adquiridos em 40 ciclos de 1 segundo cada na sequência: 1 branco, 1 padrão, 4 amostras, 1 branco e 1 padrão. Em cada leitura foram determinadas as intensidades das massas 202Hg, $204(\mathrm{~Pb}+\mathrm{Hg}), 206 \mathrm{~Pb}, 207 \mathrm{~Pb}, 208 \mathrm{~Pb}$.

A redução dos dados brutos, que inclui as correções para branco, deriva do equipamento e chumbo comum, foram realizadas em planilha EXCEL, confeccionada no próprio laboratório (Bühn et al., 2009). As incertezas associadas às razões apresentadas nas tabelas são de $1 \sigma$, em porcentagem. As idades foram calculadas utilizando o ISOPLOT 3.0 e ${ }^{238} \mathrm{U}$ (Ludwig, 2003). As análises foram realizadas no laboratório de geocronologia da Universidade de Brasília. 


\section{Capítulo 2 - O Neoproterozoico - Questões Globais}

\section{1 - Introdução - Tectônica de Placas}

A história da geologia moderna pode ser retratada sob duas vertentes. Até 1955, as ideias de um planeta rígido e de movimentos puramente verticais prevaleciam nos modelos aceitos. Deslocamentos direcionais e continentes movimentando-se lateralmente e por grandes distâncias eram obras ficcionistas. Tharp et.al., (1959) e Hess (1962) mudaram a concepção científica adotada, até então nesta época. Estes autores fundaram a base para uma proposta sobre a expansão dos assoalhos oceânicos e concluíram que o fundo oceânico se expandia a partir de um eixo central.

A partir desta descoberta, precursora da Teoria da Tectônica de Placas, esta passou a ser fundamentada por demais pesquisas, tais como: o Project Mohole, (1958-1966), Perfuração em Águas Profundas (Deep Sea Drilling Project), que propiciaram a base para um avanço no estudo tectônico. Estas descobertas revolucionaram os até então, modelos fixistas e uma nova perspectiva prosperou com cada vez mais adeptos e cientistas influentes percebendo uma nova visão mobilista.

Wilson (1965) expôs a Teoria da Tectônica de Placas, inicialmente formulando-a como uma proposta para explicar os processos de deriva continental e expansão dos fundos oceânicos. Nesta teoria reconheceu a existência de uma rede contínua de cristas de montanhas oceânicas de natureza global, associadas a falhas transformantes e as zonas de subducção, interpretadas como zonas de consumo e delimitadora destas grandes placas rígidas. Wilson explicitamente discutiu muitas das consequências do movimento relativo destas placas rígidas, como a mudança de geometria e de certos tipos de modificações por estas sofridas nas zonas de subducção.

McKenzie e Parker (1967) utilizando o movimento relativo das placas da América do Norte e do Pacífico, descreveram pela primeira vez, esta teoria e as consequências do movimento relativo de uma placa de superfície esférica, usando de matemática vetorial para prever a ocorrência de junções tríplices para quebra de crosta.

O trabalho clássico de Dewey \& Bird (1970) associou finalmente as estruturas e tectônica aos conjuntos sedimentares e vulcânicos dos chamados geossinclinais, reconhecendo que estes eram produtos que envolviam desde expansão oceânica e a contração por acréscimo e consumo de litosfera, às margens de crostas continentais e oceânicas. Como efeito haveria a formação de orógenos, resultante de consumo de crosta ao longo das zonas Benioff, com o crescimento progressivo da fossa, tanto como uma margem continental ativa ou como um arco de ilhas. A aproximação de uma massa continental, com seus sedimentos da margem, em uma trincheira resultaria em um orógeno colisional formando uma sutura entre dois continentes ou blocos crustais distintos. 
Dentro da Teoria da Tectônica de Placas cada uma destas zonas apresenta sua própria expressão topográfica, atividade sísmica e magmática, assim como a relação de seus limites e posicionamento dentro ou nas bordas destas que podem ser: Divergentes quando associadas a limites de placas que se afasta uma da outra, tal como as áreas de expansão de fundo oceânico, onde nova litosfera é gerada; Convergentes onde placas colidem e descem uma abaixo da outra e a litosfera é consumida e Transformantes onde uma placa move-se lateralmente em relação à outra e a litosfera é preservada.

Estas ideias foram cada vez mais aceitas, mas inicialmente com restrições. Windley (1986) argumentou que a maioria dos pesquisadores nesta época tinha convicção de que o modelo mobilista poderia ser sustentado desde o Mesoproterozóico. Outra parcela de pesquisadores invocava que o processo de acresção e consumo de placas não teria tido seu início antes de $1.0 \mathrm{Ga}$, Baer (1981); Kröner (1981), para explicar a evolução crustal durante o Paleo-Mesoproterozóico e Arqueano, sendo inoperantes neste período planetário.

Mesmo assim, no decorrer dos anos 80, o paradigma começa a ser fragmentado com os trabalhos de Windley (1983), Nance et al., (1986) e outros autores, onde sintetizam baseados nos estudos de suturas crustais, geofísica e evidências estruturais, que haviam cinturões orogênicos descendentes da evolução de ciclos do Wilson em épocas pré-neoproterozóicas, enfatizando o cinturão Grenville-Dalsladian, e outros como o orógeno Wopmay no Canadá, Svecokarelian Belt na Escandinávia, etc.

Estes entraves e debates no meio científico, por algum tempo estenderam-se, mas novas evidências geológicas estruturais, correlações de fácies sedimentares, padrões metamórficos e standards geoquímicos implicavam na existência de processos associados ao modelo de placas, para formação e modelagem de rochas ainda mais antigas. Contudo, ainda nesta época estudos na área de paleomagnetismo, ainda não concordavam com a existência de supercontinentes ao estilo Pangea em épocas Proterozóicas. Constata-se também o fato que o principal foco dos pesquisadores nesta época estava voltado ao arqueano, aos conceitos de greenstone belts e sua metalogenia, e aos primórdios das zonas de cisalhamento, onde os modelos mobilistas e da tectônica de placas não se encaixavam exatamente.

Todavia, Piper (1976; 1983), estudando a dinâmica das crostas continentais sugeriu e apoiou a existência de grandes massas continentais reunidas no Meso-Neoproterozóico. O trabalho baseouse em dados geofísicos globais, links de sistemas de fraturas continentais, ocorrências de províncias alcalinas, cinturões móveis, cunhando o termo supercontinente e break-up desta massa continental por volta de $1.1 \mathrm{Ga}$. 
Aos poucos no decorrer de anos, quase a totalidade de pesquisadores, com o refinamento e inovações tecnológicas e equipamentos, novos incrementos e conceitos nos estudos estruturais (Shear Belts e Shear Zones) e geotectônicos, geofísicos, petroquímicos e isotópicos vieram a agregar este modelo, consubstanciando esta hipótese e validando os processos envolvidos nos ciclos de Wilson e estendê-los como um bem-sucedido mecanismo em todo Proterozóico e no mundo todo.

A partir 1990, passou-se a entender não só o ciclo de Wilson, mas suas consequências nas sucessivas amálgamas continentais e sua desagregação contínua no tempo. Com esta visão McMenamim \& McMenamim (1990); Dalziel (1991); Hoffman (1991); Moores (1991) apresentaram o conceito de montagem e dispersão de blocos continentais e formação de supercontinentes.

A partir desses estudos McMenamim \& McMenamim (1990) propõem o nome do primeiro supercontinente gerado em $1.0 \mathrm{Ga}$, o Rodínia e outros autores começaram a identificar recuando-se no tempo geológico outras conformações continentais globais. O assunto abordado sobre supercontinentes tem crescido de forma exponencial no meio científico conforme citam Nance e Murphy (2013), associado a novos conceitos inseridos, tais como as LIPs (Large Igneous Provinces), as plumas e superplumas mantélicas.

Atualmente, novas pesquisas e propostas têm remontado antigas ideias, modelos de subducção para o Meso-arqueano (Smithies et al., 2007), especulações sobre a evolução do sistema litosfera-astenosfera terrestre - plumas, superplumas, anti-placas e placas, mecanismos e modelos, (Ernst, 2007; Maruyama et al., 2007).

Este breve histórico se fez necessário para o entendimento de visualizarem-se as áreas de estudo desta proposta de tese, não apenas como um contexto macrotectônico de arcos e bacias neoproterozóicas, mas em sua inclusão geotectônica global. Trata-se da evolução e quebra de continentes e as consequências desta fragmentação, rearranjo e remontagem de novos arcos, de acresções juvenis e crustais a um novo bloco continental, o West Gondwana, precursor do Pangea.

\section{2 - Supercontinentes}

Valentine e Moores (1970) foram, provavelmente, os primeiros a propor um supercontinente, abrangendo praticamente todas as massas emersas que existiam no final do Pré-Cambriano na Terra. Worsley et al., $(1982,1984)$ argumentaram a existência de ciclos de formação de supercontinentes e que estes se manifestariam no registro geológico por picos episódicos de orogeneses, colisão e enxames de diques máficos relacionados a rifts. Estes episódios de montagem e quebra de massas crustais, compoem o ciclo de formação dos supercontinentes que foram reconhecidas, discutidas e estudadas por Nance et al., (1986); Hoffman et al., (1999); Hoffman and Schrag, (2002); 
Dewey, (2007); Rogers and Santosh, (2002, 2004); Murphy and Nance, (2003); Torsvik, (2003); Cawood \& Buchan (2007); Santosh and Zhao, (2009); Goldfarb et al., 2010; Hawkesworth et al., (2010); Santosh, (2010a, 2010b); Condie, (2011); Yoshida and Santosh, (2011); Cawood et al., (2013); demosntrando a influencia deste ciclo na evolução geológica planetária.

Segundo a definição de Condie (2012), supercontinentes são grandes massas continentais, que incluem a maior parte ou a totalidade de continentes existentes. Para defini-los são necessárias técnicas e métodos de reconstrução. De inicio as correspondências das bordas continentais são sugestivas, presença de seções estratigráficas comuns e assembleias fossilíferas são utilizadas. Hoje, além destes métodos, são necessários processamentos computacionais para correspondência, além de dados paleomagnéticos, no intuito de entender a trajetória da paleoposição dos continentes, a direção de espalhamento dos assoalhos oceânicos, dos hotspots e a correlação de suítes supracrustais e idade de cinturões orogênicos ativos.

A partir destes estudos e evidências, alguns autores indicam diversas configurações para continentes pretéritos. Rogers (1996); Rogers e Santosh (2004) propõem que todos os blocos aumentam em diversos períodos durante ciclos de sua historia por acresção de material juvenil, relacionada à subducção e a amálgama de fragmentos cratônicos de outros continentes. Rogers e Santosh (2004) ainda afirmam mais dois pressupostos: os crátons dentro de cada um desses continentes têm a mesma idade de estabilização individual que a idade proposta do novo continente gerado e que a consistência de idade interna é improvável, uma vez que são formados pelo acréscimo de fragmentos de outros continentes durante diversos períodos.

Armstrong (1981), Sankaran (2003), confirmam as técnicas e métodos para análise da arquitetura de supercontinentes e inserem modelos para o início do crescimento da crosta terrestre admitindo uma taxa decrescente de reciclagem de novas crostas com o tempo, permitindo o alcance de um equilibro entre a taxa de perda de reciclagem e a manutenção de um estado estacionário. Taylor e McLennan, (1985), Stein \& Hoffmann, (1994) citam outra proposta que consiste em um modelo crustal estável com crescimento ao longo do tempo, com ocasionais explosões em sua produção, com reciclagem de crostas. Nesta versão, também pode ser desconsiderada a reciclagem, entendendo-a como um processo de menor consideração.

McCulloch e Bennet, (1994), acrescentam estudos e contribuições sobre a química do manto, particularmente em elementos como $\mathrm{Sr}, \mathrm{Nd}, \mathrm{Hf}, \mathrm{Nb}$ e isótopos de $\mathrm{Pb}$, o esgotamento progressivo de urânio e alguns elementos incompatíveis, assinalando a extração destes elementos para formação de crosta continental e como consequência o aumento no volume de manto depletado. Associada a dados químicos, a aplicação da tomografia sísmica para estudar o manto, revelou-se a existência de placas litosféricas subductadas e encravadas profundamente até a descontinuidade de $660 \mathrm{~km}$ (uma 
zona de transição térmica) onde atingem o manto inferior, ao contrário das ideias anteriores que julgavam que estas placas não poderiam alcançar tais limites.

Stein e Hoffmann (1994) então, fundamentado admitiram que os episódios de geração de crosta surgissem, quando placas litosféricas subductadas atingessem a barreira limite do manto inferior. Estas placas modificariam as camadas do manto, favorecendo a convecção mantélica temporariamente. Tais episódios promoveriam as “cabeças de plumas” na fronteira manto-núcleo (D” layer) transportando elementos incompativeis como reforços ao manto superior esgotado.

A consequência de todo processo, segundo Condie (2000) é uma maior produção de crosta juvenil. Esta suposição é suportada pela abundância de idades em zircão em determinados intervalos de tempo e também pelos dados isotópicos de $\mathrm{Nd}$, aglutinação de massas e uma série de outros eventos geológicos associados de síncrona incidência como abundância de folhelhos negros, depósitos de ferro, mudanças climáticas, acúmulo de $\mathrm{CO}_{2}$ e elevação de nível do mar.

Condie (2000) modelou dois estilos de formação de supercontinente: (1) Um ciclo sequencial com duração de 600-800 Ma anos começando com; (a) o rompimento de um supercontinente já existente e o início da subducção de placas seguido por; (b) formação de plumas de transferências levando material para formar um novo supercontinente; (c) com a chegada das placas profundamente no manto inferior (na camada D”), promovendo um isolamento térmico do manto. Este isolamento facilita o acúmulo de calor em outro lugar e força (d) upwellings mantélicos a quebrar o novo supercontinente criado e o ciclo se repete. Seu segundo modelo prevê a formação de um supercontinente pela incorporação de outro grande continente em que ele próprio seja submetido à fragmentação.

Finalmente, Maruyama et al., (2007) proporam seguindo o modelo de Condie (2000) que há determinadas configurações para formação de superplumas, supercontinentes e sua dinâmica mantélica e tectônica anti-placa ocorrentes na fronteira manto-núcleo. Estudando uma região do Oceano Pacífico, as quais denominaram de Zona Triangular Oeste do Pacífico (WPTZ). Julgaram-na como uma fronteira de um supercontinente futuro que será formado à $250 \mathrm{Ma}$.

A WPTZ é caracterizada por zonas de subducção de dupla face para o leste e sul e é uma região dominada por extensivo esfriamento e fornecimento de água para a cunha mantélica, pelo menos há 200 Ma. Maruyama et al., (2007) citam que longas placas inertes se estendem a $1200 \mathrm{~km}$ e estão presentes na Camada Limite Meso-Manto (MBL, 410-660 km) sob o WPTZ, enquanto que na fronteira manto-núcleo (CMB, 2700-2900 km de profundidade), há uma espessa anomalia, presumivelmente representando uma placa pretérita.

Para explicar a camada D" anômala e fria, é necessário um colapso de placas inertes na Camada Limite Meso-Manto (MBL), e estas agem como gatilho para abrir uma série ocorrências geo- 
lógicas em superficie como a formação de back-arc basins, hotspots, pequenas bacias oceânicas com a formação de uma série de microplacas em oceanos e continentes. Estes fenômenos interiores geram como resultado a substituição do manto superior por materiais mais quentes e mais fértéis do manto inferior.

O resultado mostra claramente a presença de duas grandes superplumas e um downwelling. Maruyama et al., (2007) concluem que a estrutura térmica da Terra parece ser controlada pela história da subducção e da reentrada destes materiais no manto, exceto na camada D". A estrutura térmica da camada D" parece ser controlada pela presença de placas estacionárias pretéritas, como esperado por reconstruções paleogeográficas para Laurásia, Gondwana e Rodínia por volta de cada 700 Ma. As figuras 2.1, 2.2 e 2.3 apresentam um resumo destas ideias de geração e quebra de supercontinentes.

(1) Frontier of future supercontinent

(2) $\mathrm{H}_{2} \mathrm{O}$ - rich upper mantle

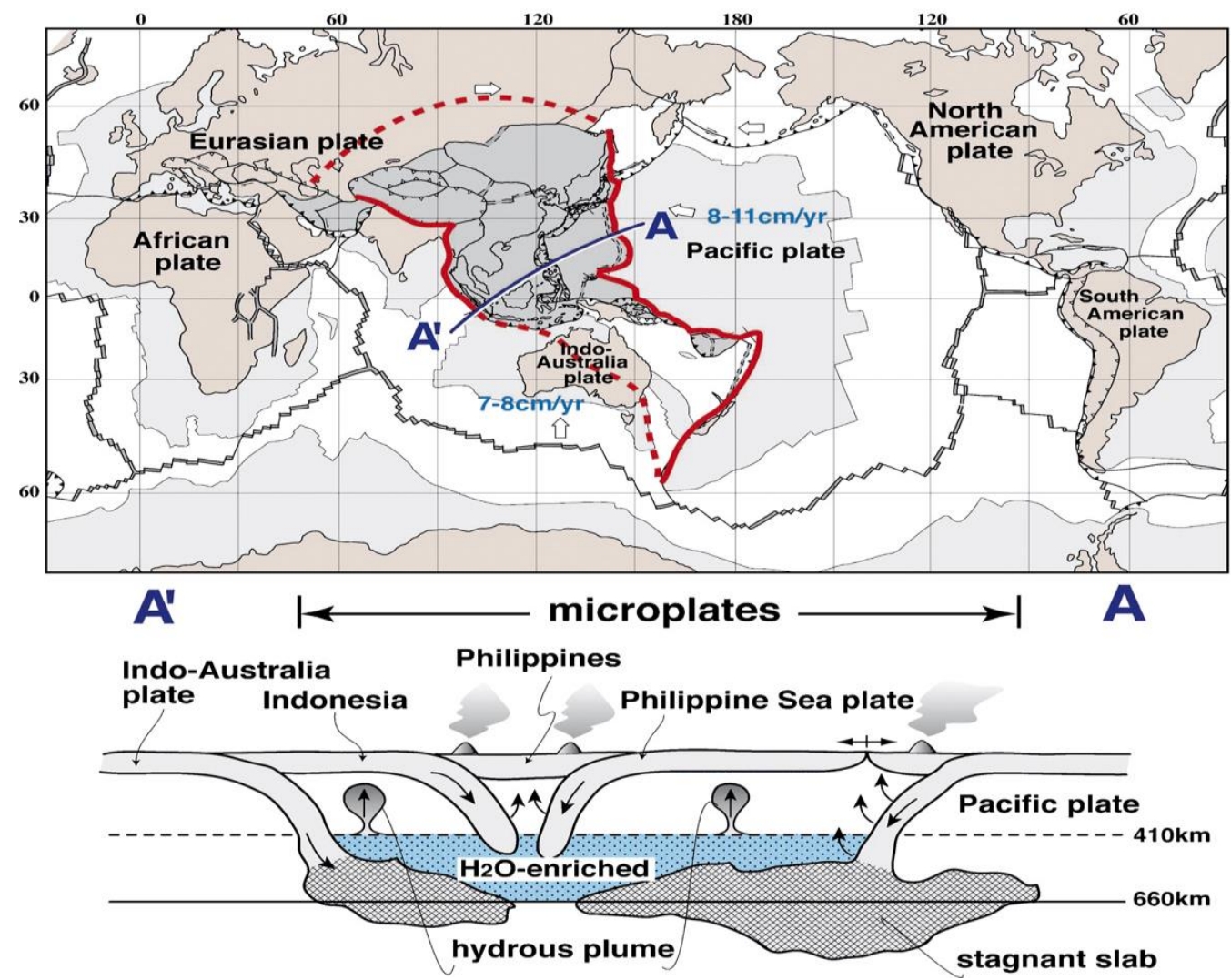

Fig. 2.1 - Concepção de Maruyama et al., (2007) com a localização da região triangular do Pacífico ocidental. O leste da Ásia é o local de uma zona de subducção de dupla face, com interação das placas antigas e frias do Pacífico a partir de leste e a placa da Indo-Austrália do sul. A subducção causa o esfriamento do manto superior e inferior e neste local são as regiões mantélicas mais frias do mundo. Isto ocorre devido à presença de uma ressurgencia ou uma superpluma fria (Maruyama, 1994), das duas faces de subducção. No entanto, a Ásia Oriental e seus arredores são as regiões mais ativas da Terra, indicando que o papel da água é de várias ordens de magnitude maior do que a temperatura em termos de redução da viscosidade e diminuição do limite da curva solidus. Nota-se também a ocorrência predominante de microplacas na região. Não apenas a fragmentação dos continentes, mas também a formação de oceanos, principal razão para a ocorrência dominante de microplacas. O esquema de seção transversal de WPTZ é mostrado para ilustrar as placas inertes. 
Placas pretéritas estacionárias e anomalias frias no CMB (Core-Mantle Boundary) no Oeste do Pacífico e regiões vizinhas

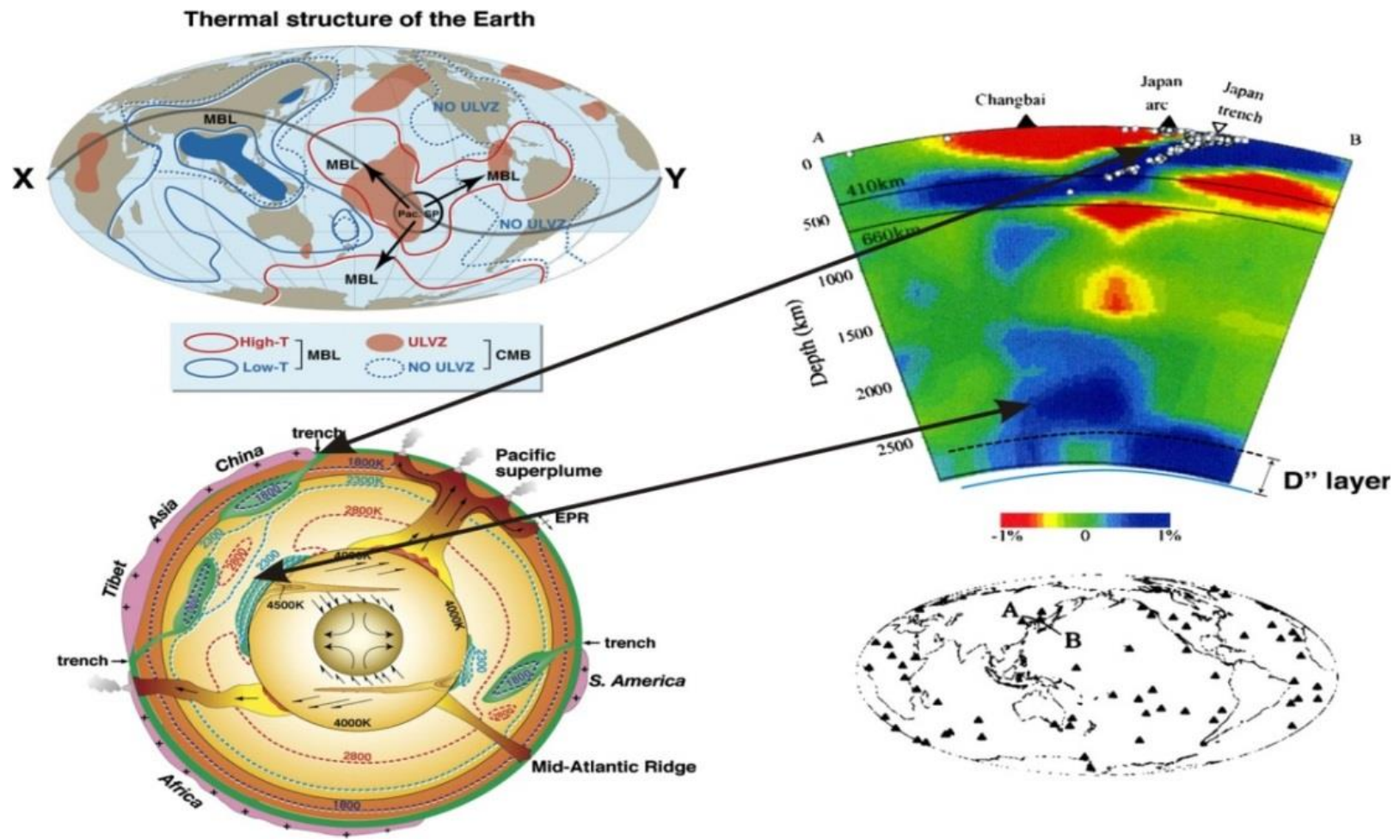

Fig. 2.2 - Concepção da Estrutura térmica da Terra em Maruyama et al., (2007). Mapa (acima) e de seção transversal (inferior). Três conjuntos de dados: (1) espessura da MBL, (2) espessura da camada D" e (3) de distribuição global (presença ou ausência) do ULVZ (Utra Low Velocity Zone) (Helmberger et al., 2000; Garnero, 2004), é usada para desenhar esses conjuntos de dados. A estrutura térmica da Terra pode ser observada ao longo do grande círculo, incluindo Tibet, China, Japão, Polinésia Francesa para a África. Todos os dados indicam a WPTZ (West Pacific Triangular Zone), com o manto mais frio de cima para baixo e as regiões mais quentes da superpluma ocupando todo manto no intervalo de profundidade de 2500 a $660 \mathrm{~km}$. A temperatura do núcleo é superior a $4000 \mathrm{~K}$ em todos os lugares. Pontos frios nos discos de downwelling CMB (Core-Mantle Boundary) no núcleo externo. Um ponto frio sob a WPTZ causa downwelling e rebaixa a temperatura do núcleo interno sólido causando um crescimento preferencial do núcleo equatorial interno por precipitação e acumulação de cristais $\mathrm{Fe}$-Ni, enquanto que os líquidos residuais menos densos, causam enriquecimento de elementos leves que sobem até a raiz da superpluma. Há possivel fuga desses elementos leves nas superplumas. Outro ponto frio Americano causa dinâmica semelhante contra o núcleo interno e a superpluma Africana. Tectonitos no núcleo interno sólido podem ser formados por esse campo de stress, em geral para produzir as orientações preferenciais de fases Fe-metálicas.

Taras Gerya (2011), confirma ou mostra a tendência destas interpretações e cita que deve haver um maior entendimento entre modelos tomográficos globais e as simulações termo-mecânicas de sísmica de alta resolução para compreender como as placas são conduzidas em profundidade no manto superior, e além à fronteira manto-núcleo e as limitações destes modelos. 

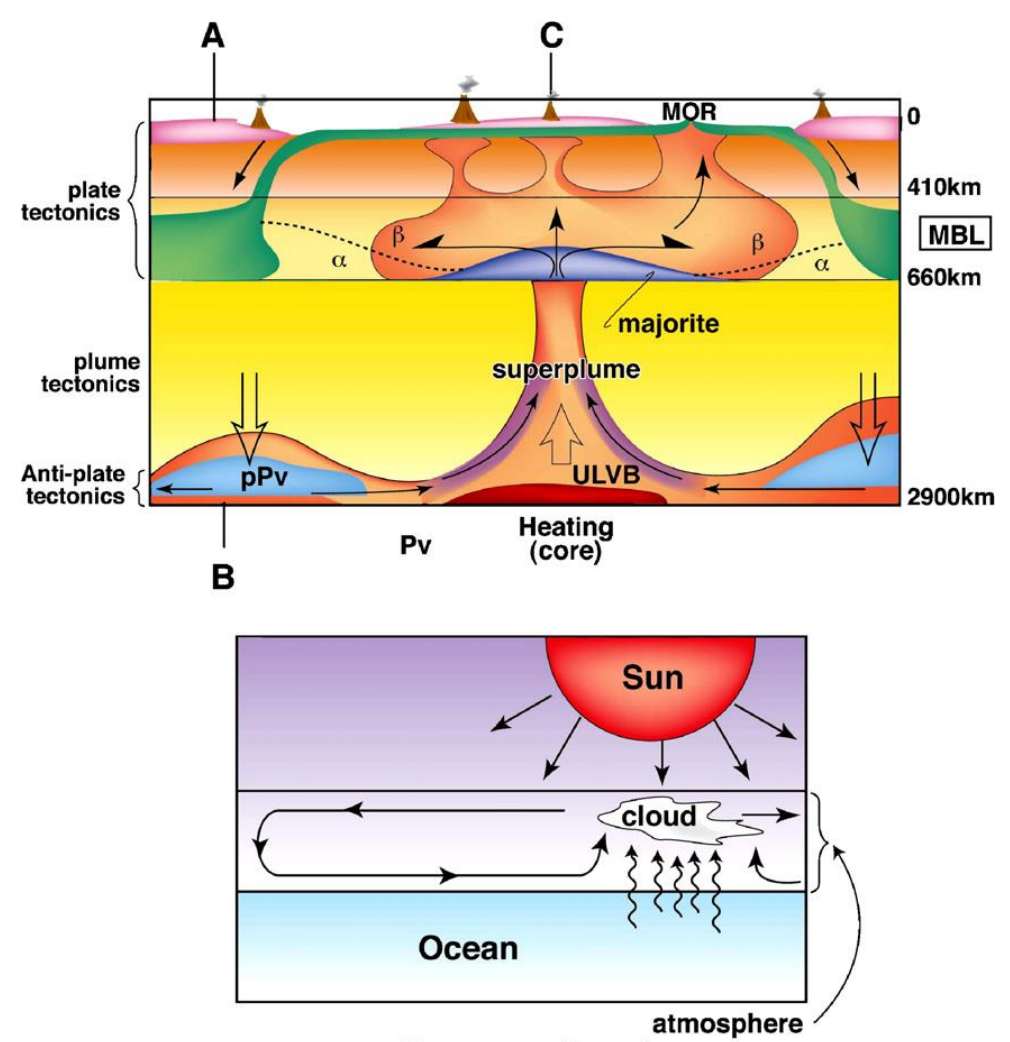

$\mathbf{N}$

Equator

Força motriz do manto dinâmica: resfriamento da superfície ou aquecimento do núcleo?

Fig. 2.3 - A força motriz para a dinâmica do manto, Maruyama et al., (2007). O aquecimento do núcleo gera uma superpluma que transporta o calor interno da Terra para a superfície. A superpluma quebra supercontinentes e continentes forçando as cadeias meso-oceânicas a produzir placas litosféricas. $O$ arrefecimento desempenha um papel subordinado para produzir a força e empuxo das placas para promover a subducção e circulação de materiais, de alto a baixo no manto em uma escala global. A figura inferior mostra o estilo similar de convecção na superfície da Terra. A energia solar impulsiona a circulação atmosférica equatorial para as regiões polares. A força motriz mais eficaz é derivada do aquecimento fornecido pelo Sol, e não pelo resfriamento do espaço planetário. Da mesma forma, o calor do núcleo é a causa mais importante da dinâmica do manto.

\section{3 - Neoproterozóico no Mundo - De Rodínia a Gondwana.}

O inicio do Neoproterozóico correlaciona-se com a história do supercontinente Rodínia (1.0 $\mathrm{Ga}$ ) sua formação, dissolução e culmina com a montagem posterior de Gondwana ( $0,5 \mathrm{Ga})$. O Continente Rodínia foi construído por eventos orogênicos com evidências em todo mundo entre 1300 Ma e $900 \mathrm{Ma}$, envolveu todos ou a maioria dos blocos continentais conhecidos e tem como modelo e processo a acresção ou a colisão de blocos continentais ao redor da margem de Laurentia para sua edificação.

O conceito do supercontinente atraíu muita atenção em 1991, quando três pesquisadores (Moores, 1991; Dalziel, 1991; Hoffman, 1991) publicaram evidências geológicas para a montagem e quebra de um supercontinente denominado de Rodínia, com alguns de seus continentes sucessores formando o Gondwana. Uma síntese é exposta em Li et al., (2008) da seguinte forma: A estabiliza- 
ção do continente Rodínia durou cerca de 150 milhões de anos após a montagem completa. Eventos mantélicos, causados pela subducção de placas acumuladas na zona de transição do manto em torno do supercontinente, além de isolamento térmico, levou à formação de uma superpluma mantélica abaixo e sob seu interior e ocorreu cerca de 40-60 Ma após a conclusão de sua montagem.

Como resultado, difundiram-se sistemas de rifts continentais entre $825 \mathrm{Ma}$ e $740 \mathrm{Ma}$, com eventos episódicos em pluma em $825 \mathrm{Ma}, 780 \mathrm{Ma}$ e $750 \mathrm{Ma}$. Assim como sua montagem, a quebra de Rodínia ocorreu diacronicamente. O primeiro grande evento de fragmentação ocorreu ao longo da margem ocidental do Laurentia, possivelmente já em750 Ma. Rifts entre o Cráton Amazônico e a margem sudeste da Laurentia iniciaram aproximadamente ao mesmo tempo, mas só levou a quebra totalmente após 600 Ma. A esta altura a maior parte dos continentes gondwânicos ocidentais tinham-se juntado, embora a formação de Gondwana não fosse completa até cerca de $530 \mathrm{Ma}$.

Em detalhes podem-se considerar as seguintes etapas de importância neste período. A partir de 1100 Ma a Laurentia, Sibéria, norte da China, Cathaysia (parte do Sul da China) e, talvez, Rio de La Plata já estavam juntos e o Cráton Yangtze tinha começado sua colisão oblíqua com Laurentia. No entanto, todos os outros blocos continentais ainda estavam separados por oceanos.

No período entre 1090-1030 Ma colisões contínuas ocorreram e marcaram intenso metamorfismo (Anderson e Davis, 1995). Margens convergentes foram desenvolvidas entre a maioria dos continentes, como a litosfera oceânica entre eles consumida. Aos 1000 Ma grande parte dos blocos da Índia, Austrália, Antártida Oriental e Tarim tinham se acoplado para se juntar com Laurentia. Movimentos transpressionais preponderavam o que explica entre 1100-1000 Ma idades metamórficas relatadas (Bruguier et al., 1999; Fitzsimons, 2003).

Por volta $900 \mathrm{Ma}$ todos os grandes blocos continentais conhecidos tinham se agregado para formar o supercontinente Rodínia. As evidências estão marcadas pelos eventos orogênicos em 920880 Ma que incluem arcos vulcânicos e obducção de ofiolitos com esta idade, além de suturas que ocorrem entre 950-900 Ma. Arcos vulcânicos ao longo da margem norte do Cráton Yangtze entre 990-900 Ma com eventos metamórficos de alto grau, na Índia e na Província Rayner correspondente na Antártida Oriental.

Os eventos de 900 Ma provavelmente induziram a reativação da orógenos mais velhos dentro de Rodínia. Na região do noroeste da Laurentia nas Montanhas Mackenzie, há evidências de um evento de compressão leste-oeste em algum momento entre 1033 Ma e 750 Ma (Thorkelson, 2000; Thorkelson et al., 2005). No sul dentro do Cráton Australiano uma série de orógenos se desenvolveu e prosseguiu até $900 \mathrm{Ma}$.

O break-up de Rodinia pode ter outra interpretação quando observamos alguns fragmentos cratonicos e arcos sincronos. Pimentel et al., $(2000,1997,1992)$ incluem uma grande área com ar- 
cos magmáticos intraoceânicos, formados por subducção de litosfera oceânica, cujas assinaturas isotópicas indicam derivação juvenil e manto-reciclado. Esta é a principal evidência para a existência de uma grande parte de um domínio oceânico, datado de cerca de 900 -800 Ma, que ocupava o que é hoje o Brasil-central e estendida para o nordeste no Oceano Goianides-Pharusian (Trompette, 1994; Fetter et al., de 2003).

Isto implica que, enquanto o nucleo de Rodínia formava-se em torno de Laurentia, incluindo a Amazônia e a África Ocidental, um grande oceano estava separando este núcleo de algumas outras massas continentais e fragmentos, compreendendo os crátons São Francisco-Congo, Rio de La Plata e Kalahari. Cordani et al., (2003) e Kroener e Cordani (2003) usou essa observação, válida para o tempo de aglutinação de Rodínia, a propor que estes fragmentos cratônicos nunca foram partes da Rodínia.

O período de 860-570 Ma é marcado por outros fenômenos geológicos de natureza distinta, eventos de superplumas, rifteamento continental levaram a um longo processo de dissolução de Rodínia. Dados paleomagnéticos para o intervalo de tempo entre 900 Ma e 830 Ma são escassos. Poucos registros geológicos são disponíveis sobre o Rodínia dentro deste intervalo de tempo e um pequeno número de intrusões em 870-850 Ma são destacadas, bem como magmatismo bimodal em $845 \mathrm{Ma}$ e $870 \mathrm{Ma}$. Também foram relatados magmatismo bimodal nas Caledonides escandinavas (Paulsson e Andreasson, 2002) e da Laurentia (Dalziel e Soper, 2001), ambos interpretados como o início break-up do continente Rodínia. Li et al., (2003) sugeriram que estas intrusões seriam o primeiro sinal de uma superpluma.

Atividade generalizada de plumas não ocorreu até $825 \mathrm{Ma}$, como mostrado por enxames de diques máficos, intracontinentais, intrusões máfico-ultramáficas e intrusões félsicas (resultante da fusão crustal ou diferenciação de magma). Após esta idade, no entanto, tal magmatismo é comumente encontrado. Em alguns lugares rochas intrusivas são discordantemente recobertas por sucessões vulcanoclásticas relacionadas à rifts de mesma idade, sugerindo domeamentos sin-magmáticos, Li et al., (1999) e Li et al., (2003) este evento magmático generalizado em grande parte síncrono é interpretado, como o primeiro grande episódio de eventos superplumas que levaram à dissolução de Rodínia.

O hiato sedimentar comum e global encontrado entre 900-880 Ma e em $820 \mathrm{Ma}$, é apontado a uma pluma mantélica que induziu o soerguimento crustal. Além deste evento de superpluma sugerida, intrusões gabróicas e monzoniticas, de idade similar, são relatadas e interpretadas como indicativos de rifteamento continental, (Reginiussen et al., 1995).

Unrug (1992) acrescenta que neste período eventos de colisão e deformação ocorreram no intervalo 820 até 540 Ma. O primeiro evento de colisão iniciado em 820 Ma entre o Cráton São 
Francisco-Congo e o Leste Gondwana formando o cinturão Zambeze. Unrug (1992) cita que imensas zonas de cisalhamento transpressionais e cinturões móveis com magmatismo orogênico foram eventos marcantes que se consolidaram com a formação do W Gondwana no intervalo 660-500 Ma.

A exceção de Kalahari e, talvez, alguns terrenos menores, West Gondwana foi amalgamado por volta de $600 \mathrm{Ma}$. No entanto, os oceanos ainda existiam entre Austrália-Antártica Oriental, Índia, África Oriental e Kalahari por volta de 550 Ma, a Índia mudou a sua posição ao longo da margem do Gondwana ocidental da Austrália, registrados por imensas descontinuidades com movimento transcorrente sinistral. Por volta deste período, também o Kalahari começou colidir com Congo e Rio de La Plata, fechando assim o Oceano Neoproterozóico Adamastor entre eles, (Prave, 1996).

Li, et al., (2008), novamente ilustra o modelo e a mecânica de plumas com esse evento: Com o isolamento térmico de um supercontinente elevando-se a temperatura do manto superior sugerindo que a força motriz para a geração dominante do manto são as superplumas que formam um "empurrão para cima" (circum-Rodínia) e efeito das placas em subducção abaixo das margens do supercontinente que as isolam ao centro.

Na superfície da superpluma apareceria um "cluster plume" ou um conjunto de plumas (Ernst \& Buchan, 2002; Schubert et al., 2004) consistindo em plumas "secundárias" originárias na porção superior da superpluma (Courtillot et al., 2003).

Esse mecanismo poderia explicar a natureza bipolar da ocorrência de superplumas, como ilustrado pelas atuais superplumas África e Pacífico (vid. Zhao, 2001; Courtillot et al., 2003). O modelo assim preveria a ocorrência de numerosos planaltos oceânicos e montes submarinos nos oceanos, no lado oposto da Terra de Rodínia, os traços de que seria encontrada nos orógenos de idade "Pan-Africana", em partes do escudo Arabian-Nubian; (Stein e Goldstein, 1996). Este modelo concorda com Condie $(1998,2000)$ na medida em que as superplumas são resultados das placas laterais que afundam ao manto.

Em 825 Ma este evento superpluma, é seguido por rifteamento continental, que permaneceu por 25 milhões anos, associado a um pico magmático mais fraco por volta de $800 \mathrm{Ma}$ e $790 \pm 5 \mathrm{Ma}$ (Li et al., 2003). Por esse tempo Rodínia havia se afastado das regiões polares para norte no intervalo de 770-750 Ma, embora nenhum registro de rifteamento continental e break-up têm sido relatados para esse intervalo. A rápida rotação de Rodínia entre 820-800 Ma e 780-750 Ma é interpretada por Li et al., (2004) como um verdadeiro evento relacionado com a ocorrência de uma superpluma em alta latitude (Evans, 1998, 2003; Li et al., 2003).

O mecanismo proposto para a formação da superpluma do supercontinente Rodínia foi possivelmente aumentada pelo efeito de isolamento térmico do supercontinente e as implicações paleomagnéticas apontam que, tanto a superpluma, como o Rodínia acima podem ter se movido, a partir 
de uma posição de alta latitude, para uma posição equatorial entre 820-800 Ma e 780-750 Ma (Li et al., 2004), o que implicaria em convecção de todo o manto. Como efeito, impulsionaria os processos de subducção, em que temos convecção geral do manto, e não somente pelo calor estacionário de fontes na fronteira manto-núcleo.

Por volta de 750 Ma supõe-se que a metade ocidental de Rodínia começou a quebrar acima de uma superpluma equatorial. O magmatismo bimodal de idade 755-750 Ma observado em todo continente como sucessões de rift. No intervalo de 750-700 Ma ocorre também a primeira grande glaciação Sturtiana de natureza global e em baixa a moderada latitude e está marcada em todos continentes. Entre 650-630 Ma, os blocos continentais que se dispersaram alinharam-se ao longo do paleoequador. Uma segunda glaciação de baixa latitude generalizada denominada de Marinoana, instalou-se (Hoffman e Schrag, 2002). Inúmeras causas possíveis para estes eventos climáticos globais e enigmáticos foram propostos e todos são altamente controversos.

Em 600 Ma, os crátons Amazônico, África Ocidental e Congo-São Francisco tinham grande parte se reunido durante a Orogenia Brasiliana e concluído sua colisão até o Cambriano ou mais tarde pela orogênese Pampeana. Li, et al., (2008) ainda admite que o rifteamento ao longo destes blocos continentais entre $630 \mathrm{Ma}$ e $550 \mathrm{Ma}$, possa ter sido o responsável pelo afundamento generalizado registrado nas margens de muitos destes blocos. Entre 600-530 Ma ocorre o nascimento do continente Gondwana. Hoffman (1991) sugeriu pela primeira vez que o break-up da fragmentação do supercontinente Rodínia envolveu peças continentais se afastando de Laurentia e colidindo no outro lado da terra para formar Gondwana. Toda esta dinâmica é ilustrada na fig. 2.4 e fig. 2.5 nas propostas de Hoffman (1991), Li et. al., (2008), Thover et al., (2006), Grey et al., (2007) e Stern e Johnson, (2010), Johansson (2014).

O Gondwana finalmente estava amalgamado em 540-530 Ma o que é suportado por análises paleomagnéticas. O Mesoproterozóico e Neoproterozóico tardio são os intervalos de tempo mais notáveis na história da Terra. Durante este período vemos a montagem e dissolução do supercontinente Rodínia, ancestral do continente Gondwana. Eventos de superplumas, repetidas glaciações de baixa latitude, e finalmente, a explosão da vida multicelular (McMenamin e McMenamin, 1990) com uma dinâmica de placas e sistema climático muito semelhante ao que temos hoje (Moores, 2002; Evans, 2003a). 


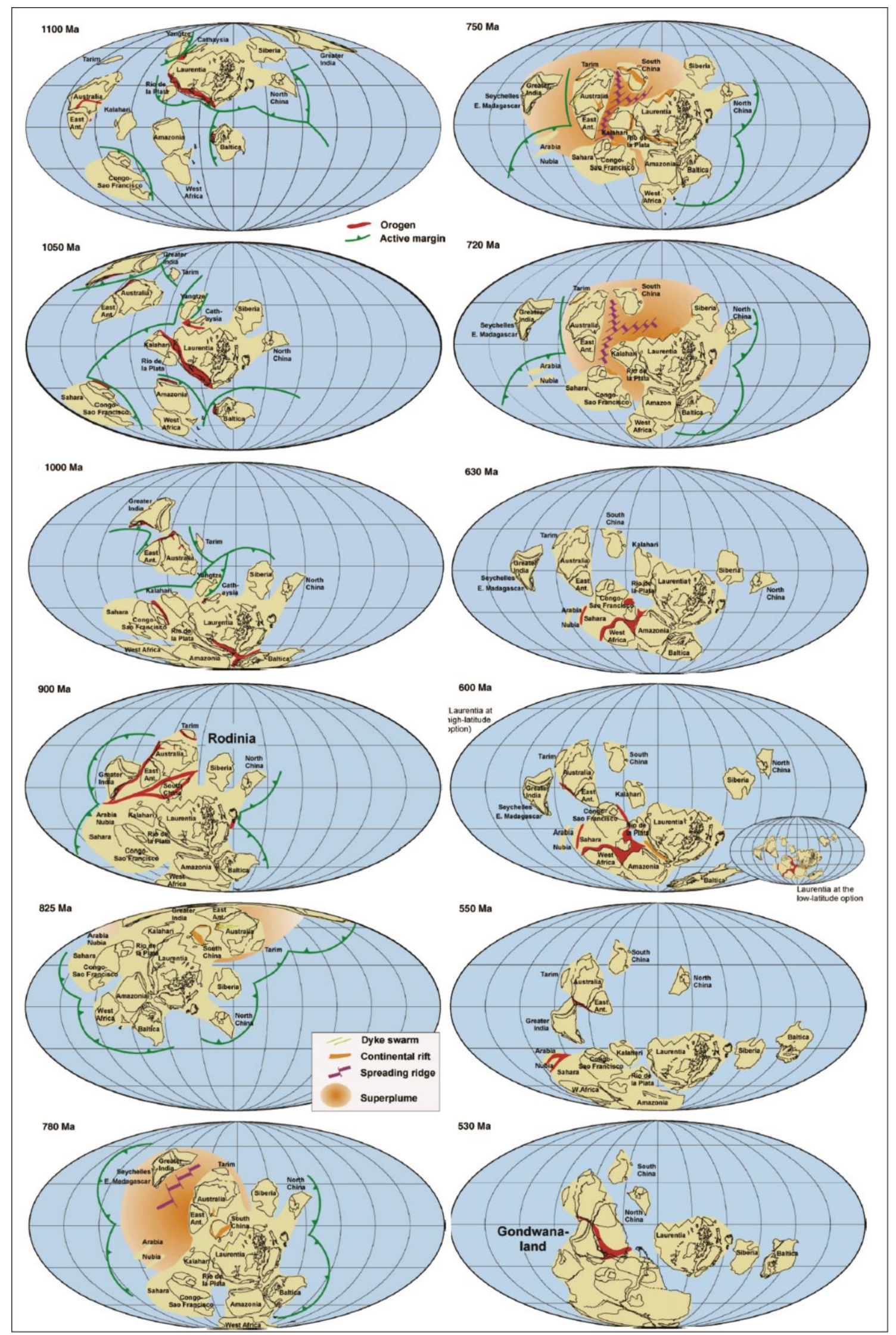

Fig. 2.4 - Evolução Geológica do Neoproterozóico desde 1.1 Ga a 0.53 Ga, montagem e quebra de Rodínia e Gondwana conforme Li et al., (2008). 

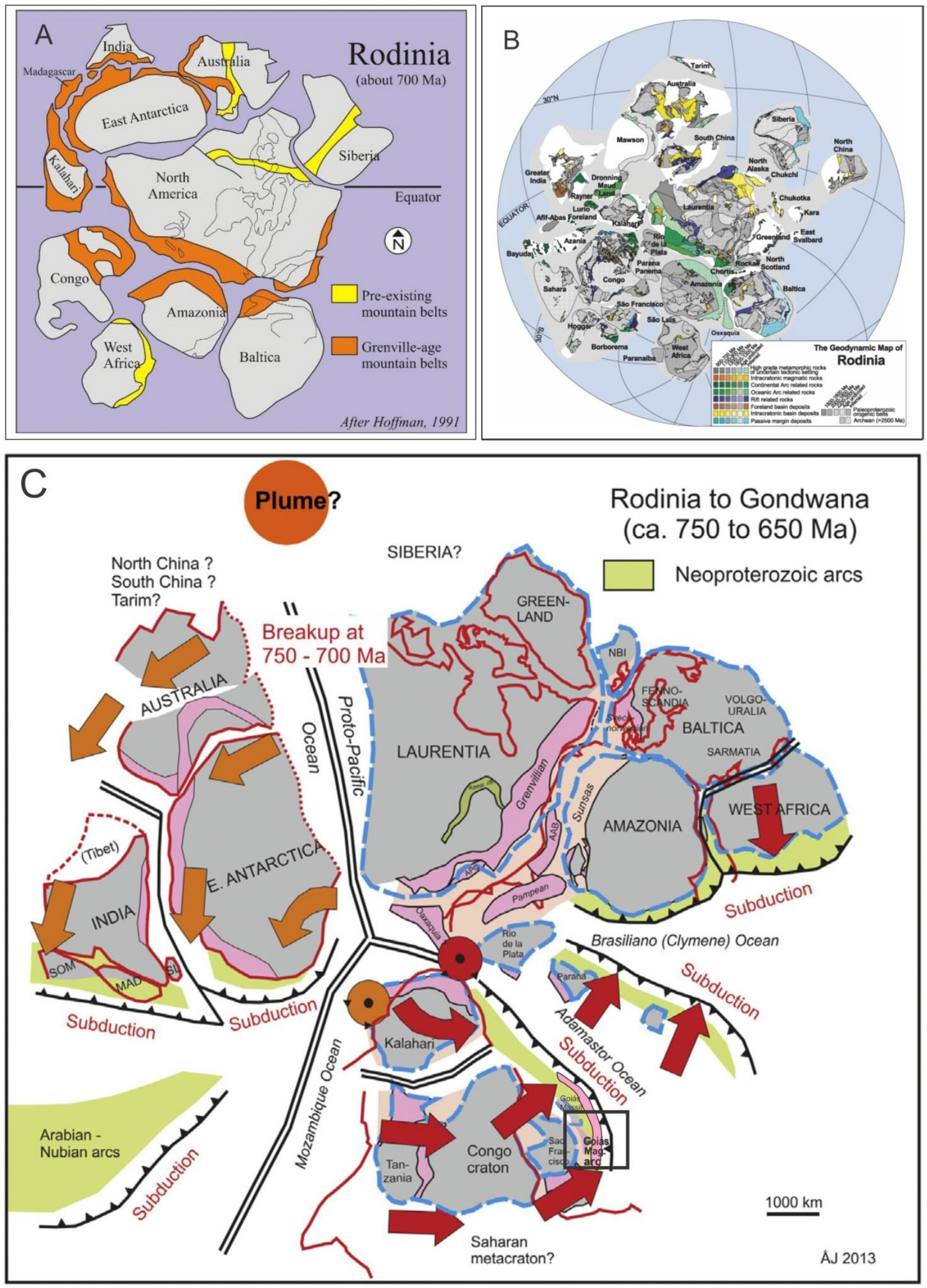

Fig. 2.5- Esquema de quebra de Rodínia e amalgamação e formação do Gondwana, conforme (A) Hoffman (1991), (B) Li et. al., (2008), (C, D, E) Johansson (2014). 

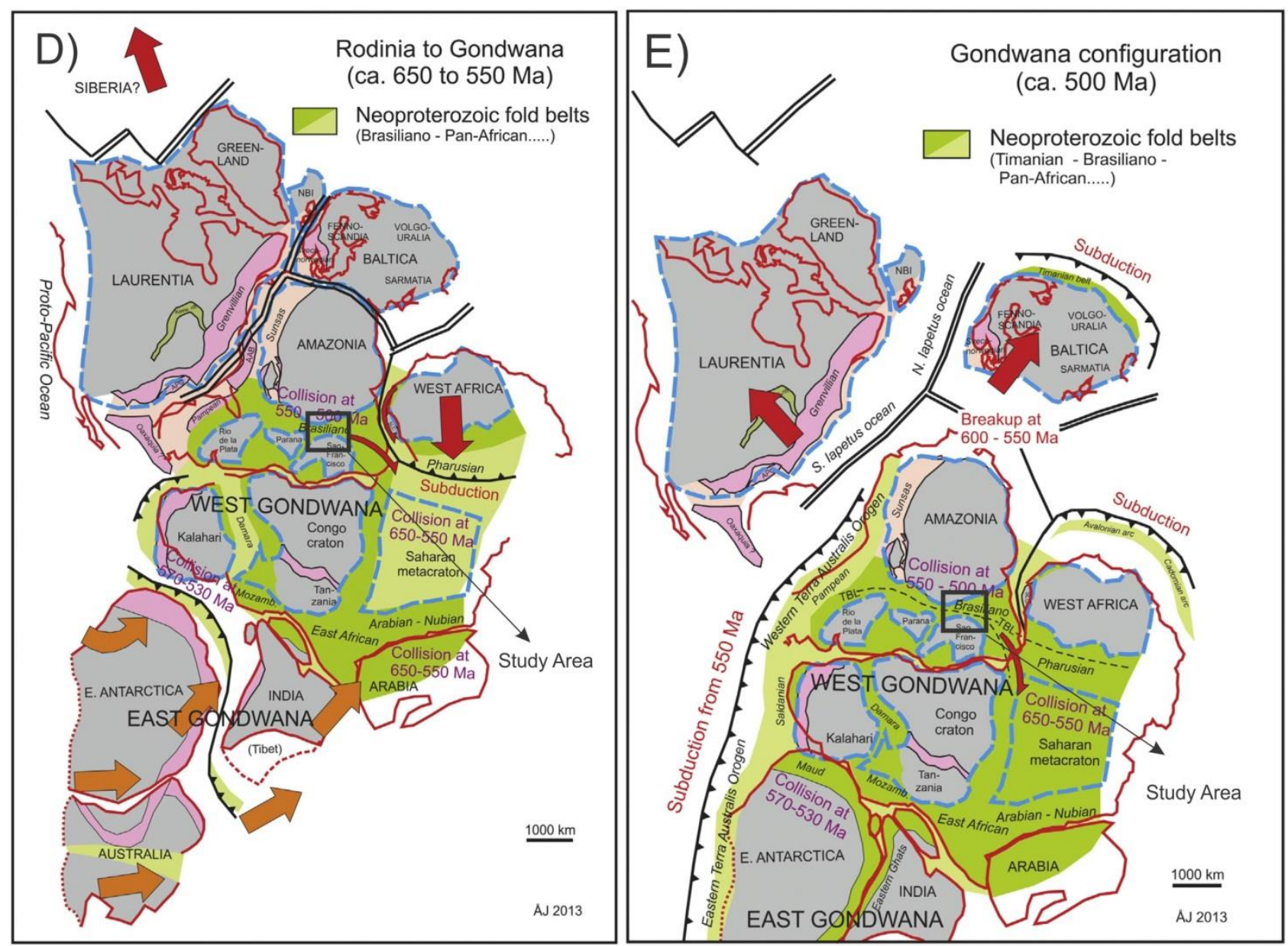

Continuação-) Fig. 2.5 D, E, Johansson (2014), formação do W- Gondwana e localização área de estudo (retângulo em preto) -.

\section{4 - O Neoproterozóico na América do Sul -}

\section{Conexões com Provincias Estruturais Cronocorrelatas}

Brito Neves et al., (1999) expoem uma caracterização geotectônica da Plataforma Sulamericana, com enfoque em relação ao Ciclo Brasiliano e seus constituintes geodinâmicos. O embasamento da plataforma sulamericana é descrito em termo de seus elementos litoestruturais e tectônicos constituídos de três grandes colagens orogênicas: Paleoproterozóicas Médio (ou Transamazônica), fim do Mesoproterozóico / início do Neoproterozóico e Tardi-Neoproterozóico / Cambriano, a colagem Brasiliana-Pan Africano. As duas primeiras colagens têm seus registros no embasamento de seus crátons e a última nos cinturões de dobramento sin-evento Brasiliano, (fig. 2.6).

Há blocos de grandes dimensões (e.g., os núcleos arqueanos e cinturões paleoproterozóicos dos crátons Amazônico, West África-São Luís, São Francisco-Congo, Rio de La Plata), os blocos de ponto intermediário (e.g., Pampia, Central de Goiás) e pequenos blocos (Guanhães, Curitiba, Juiz de Fora, Luís Alves). Brito Neves et al., (1999), concluem que apenas observações baseadas 
em métodos e dados isotópicos e geoquímicos são capazes de apontá-los, mas sempre antecedidos pela metodologia clássica de mapeamento, ferramenta imprescindível ao conhecimento destas áreas.

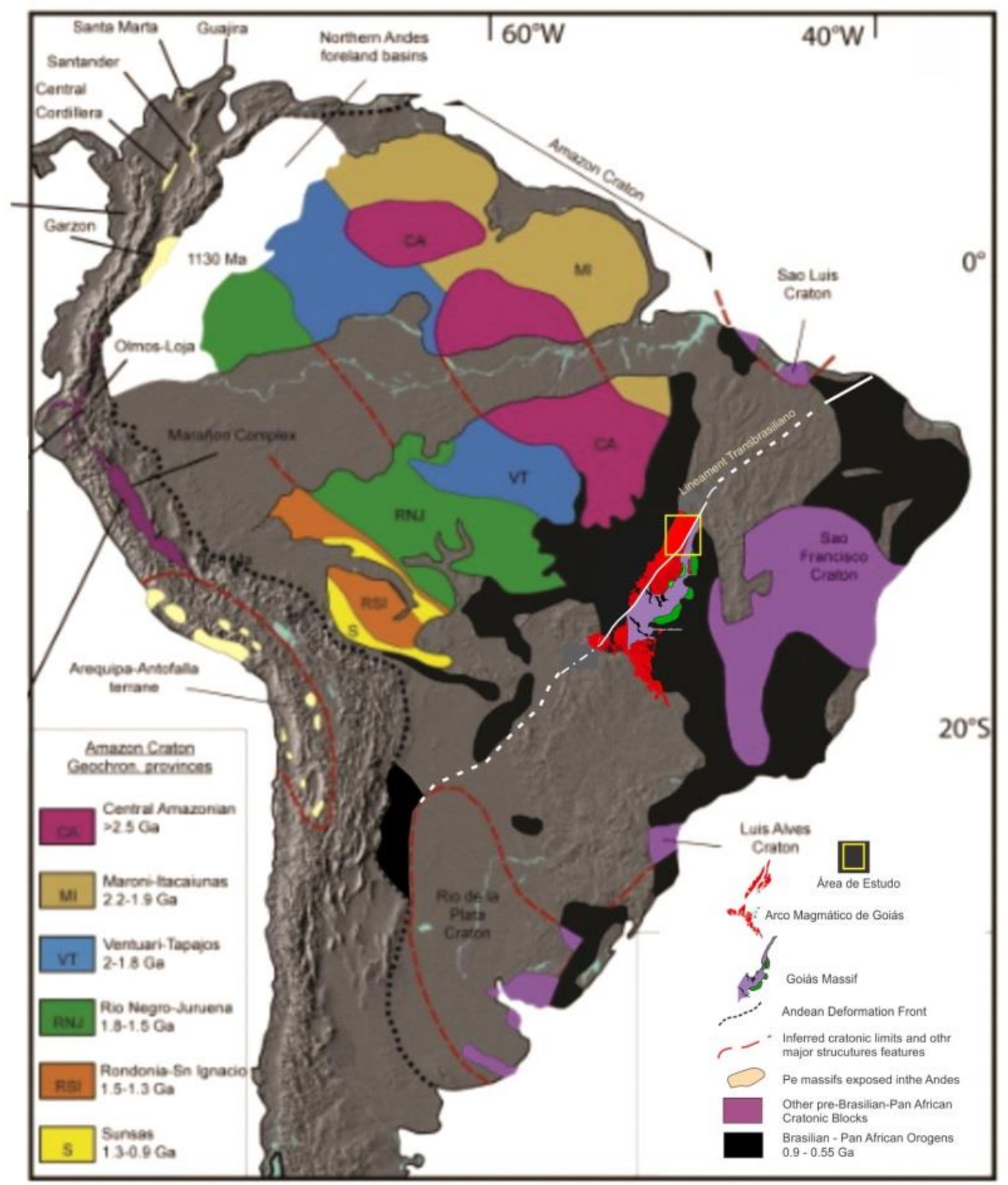

Fig. 2.6 - Mapa geológico regional da América do Sul mostrando as principais características tectónicas da "plataforma sul-americana". Províncias geocronológicas do Cráton Amazônico e inliers pré-Mesozóico andinos Cordani et al.,(2000).

O desenvolvimento da colagem Brasiliana- Pan Africana iniciou-se no Neoproterozóico, com os primeiros eventos de ruptura do supercontinente Rodínia. Foi caracterizado em seus primórdios por sua simultaneidade de eventos e foi concluída no Cambriano. 
Diferentes segmentos litosféricos foram então, gerados e envolvidos. Crátons, terrenos e maciços de diversas dimensões foram se associando ao mesmo tempo, a diferentes tipos de bacias com crostas proto-oceânicas formadas entre eles. As subsequentes interações entre estes blocos, descendentes de Rodínia, ocorreram em todo o Neoproterozóico, desde o Toniano ao período Cambriano, de acordo com as circunstâncias tectônicas locais, de uma província para a outra, até a colisão de todas as bacias, em diferentes fases de convergência tectônica.

Neste sentido enfocam-se neste estudo as províncias estruturais neoproterozoicas e cambrianas correlatas à Provincia Tocantins e com influência na área de tese por continuidade estrutural: as Provincias Pampia e Borborema.

A orogenia Pampeana (Ramos 1988, Rapela et al., 1998) é uma questão em controverso com relação ao seu link com a província Tocantins e continuidades estruturais. Há duas vertentes em relação a este caso:

Para Casquet et al., (2012), a porção norte da margem oriental do Pampia é uma placa pertencente ao ciclo Brasiliano e foi desenvolvida ao longo do cráton do Paranapanema, durante a colisão e fechamento do Oceano Climene no Cambriano, O setor sul da margem leste parcialmente coincide com a extensão do Lineamento Transbrasiliano (LTB), que justapõe o Cráton Rio de La Plata com o Pampia. Nesta provincia uma feição é característica: a Serra de Córdoba (Pampeana Oriental) que apresenta registros litoestruturais indicativos de um orógeno colisional. Esta colisão desenvolveu-se entre as microplacas e o Cráton Rio de La Plata (ou uma massa de terra continental anteriormente aglutinada, a leste de Gondwana). Os dados geocronológicos para estes processos são bem limitados no espaço de 533 a 519 Ma (Rapela et al., 1998). Para esta corrente de pesquisa a área Pampia teria sua continuação natural na Faixa Paraguai, parcialmente escondida pelos sedimentos cenozóicos do Chaco a qual se estende e conecta-se com o Lineamento Transbrasiliano.

Esta feição estrutural, o Lineamento Transbrasiliano, compõe um sistema de zonas de cisalhamento transcorrentes dextrais, de direção NE-SW, que transecta o Brasil desde o Ceará até o Mato Grosso do Sul, ligando-se a Argentina nas Serras pampeanas. Este lineamento é a principal estrutura que compõe a Provincia Tocantins, e conforma todos seus orógenos, Brasília, Araguaia e Paraguai. Ainda em relação ao vetor de movimentação do Lineamento Transbrasiliano, autores como Hasui (2010), Hasui \& Ponçano (1978), Assumpção et al.,(1986), discordam desta cinemática atribuindo sentidos vetoriais opostos e sendo de cinemática principal sinistral.

Todavia, há uma segunda linha de pesquisa que nega estas conexões, onde indicam discordâncias geológicas: Cordani et al., (2013) divergem entre uma correlação da provincial Pampia e Tocantins (Orógeno Paraguai), pois entendem que elas apresentam significados tectônicos diferen- 
tes e não possuem elementos litológicos, metamórficos e trends estruturais similares, incluindo incertezas sobre a existência do oceano Climene na região.

Cawood (2005) sugerem que ao longo da margem de Gondwana por volta de 570 Ma ocorram processos de subducção, nomeando este orógeno como "Terra Australis Orogen" e que compreendia vários orógenos acrescionários. Neste sentido a orogenia Pampeana seria o representante da América do Sul na Terra Australis.

Segundo Ramos (1988), o Pampia Oriental varia em grau de metamorfismo e inclusive rochas de alto grau são reconhecidas e formadas como o resultado de subducção da litosfera oceânica, seguida por colisão entre o Cráton Rio de la Plata e o microcontinente Pampia. Dados geocronológicos indicam uma idade até cambriana em seu desenvolvimento e fazem correlações com outros orógenos não pertencentes à plataforma sulamericana.

Para o norte a Provincia Tocantins tem sua correlação e seu prolongamento para Província Borborema. Nesta província formam megazonas de cisalhamento transcorrentes de direções predominantes leste-oeste e cinemática dextral, com destaque para o Lineamento Pernambuco e o Lineamento Patos, entre as quais ocorrem outras zonas de cisalhamento transcorrentes, com direções em torno de NE-SW, formando sigmóides de cinemática, tanto dextral, como sinistral. O arranjo geométrico do conjunto caracteriza megaestruturas tipo duplex transcorrentes, que se conectam e configuram uma terminação tipo "rabo de cavalo" de escala continental, (Vauchez \& Nicolas, 1991).

Reativações durante o Fanerozóico estão registradas como falhas normais e fraturas em sedimentos paleozóicos da Bacia do Parnaíba ou evidenciadas pelo controle estrutural e preservação de várias bacias sedimentares mesozóicas, transtracionais, em vários pontos da Província Borborema (bacias Araripe, Rio do Peixe, Iguatu, etc.). Cavalgamentos frontais e oblíquos são muito subordinados na Província Borborema, exceto no âmbito das faixas de dobramentos Sergipana e Riacho do Pontal, marginais ao Cráton de São Francisco, com vergências para sul e sudoeste. 


\section{Capítulo 3- Contexto Geológico Regional}

A Província Estrutural do Tocantins (Almeida et al., 1981) situada na região centroocidental do Brasil, abrange os estados de Goiás, Tocantins e o Distrito Federal, e partes meridionais dos estados do Pará, Mato Grosso, e oeste do Mato Grosso do Sul e Minas Gerais. Constitui um sistema de orógenos brasilianos caracterizado por três importantes cinturões: Brasília, Araguaia e Paraguai, resultantes da convergência e colisão dos blocos continentais Cráton Amazônico a oeste, Cráton São Francisco a leste e a sudoeste o Cráton Paranapanema.

Estes sistemas de orógenos brasilianos são as unidades de significância e bem preservadas da província, por sua importância geotectônica e metalogenética na estruturação e evolução do escudo brasileiro, Pimentel et al., (2000), Pimentel et al., (2004), (fig. 3.1). Os dois orógenos de maior importância neste estudo são os orógenos Brasilia e Araguaia, às quais será dada ênfase. Não obstante a faixa Paraguai faz parte desta província na montagem do West Gondwana e considerações sobre evolução desta serão abordadas em segundo plano.

As primeiras propostas de compartimentação geotectônica foram de Almeida $(1967 ; 1968)$, Almeida et al., (1976; 1977; 1981) e Hasui \& Almeida (1970) onde realizaram o primeiro estudo geocronológico Rb-Sr e K-Ar de grande abrangência na Província Tocantins.

Estes autores enfatizaram os seguintes aspectos: (i) a Faixa Brasília é constituída por várias unidades de rochas metassedimentares depositadas e deformadas na borda oeste do Cráton do São Francisco, (ii) o metamorfismo e a deformação são progressivos e mais intensos em direção a oeste, (iii) idades K-Ar confirmavam a importância do evento termal neoproterozóico, mas também indicavam com freqüência rochas mais antigas recicladas no evento Brasiliano, e (iv) grandes terrenos gnáissicos e granulíticos, expostos especialmente nas suas porções centro, oeste e norte constituiriam o embasamento antigo das sequiências supracrustais da faixa, compreendendo o denominado Maciço Mediano de Goiás (Almeida et al., 1976; Marini et al., 1984).

Fuck et al., (1993), Fuck (1994), Pimentel et al., (2004), apresentaram a Província Tocantins dividida nas seguintes unidades tectônicas, (fig. 3.1): Zona Cratônica e Maciço de Goiás, a Faixa Brasília com suas Zonas Interna e Externa, o Arco Magmático de Goiás e a Faixa ParaguaiAraguaia. Nessa proposta, individualizaram o Maciço de Goiás como um microcontinente envolvido nos processos colisionais brasilianos e destacaram deste, uma faixa de acresção crustal neoproterozóica, denominada de Arco Magmático de Goiás (Pimentel et al., 1991; Pimentel e Fuck, 1992). Esses autores identificaram na Faixa Brasília dois segmentos distintos (zonas externa e interna) que 
se diferenciam um do outro pela intensidade deformacional a que foram submetidos e por apresentarem polaridade metamórfica crescente em direção à zona interna da faixa.

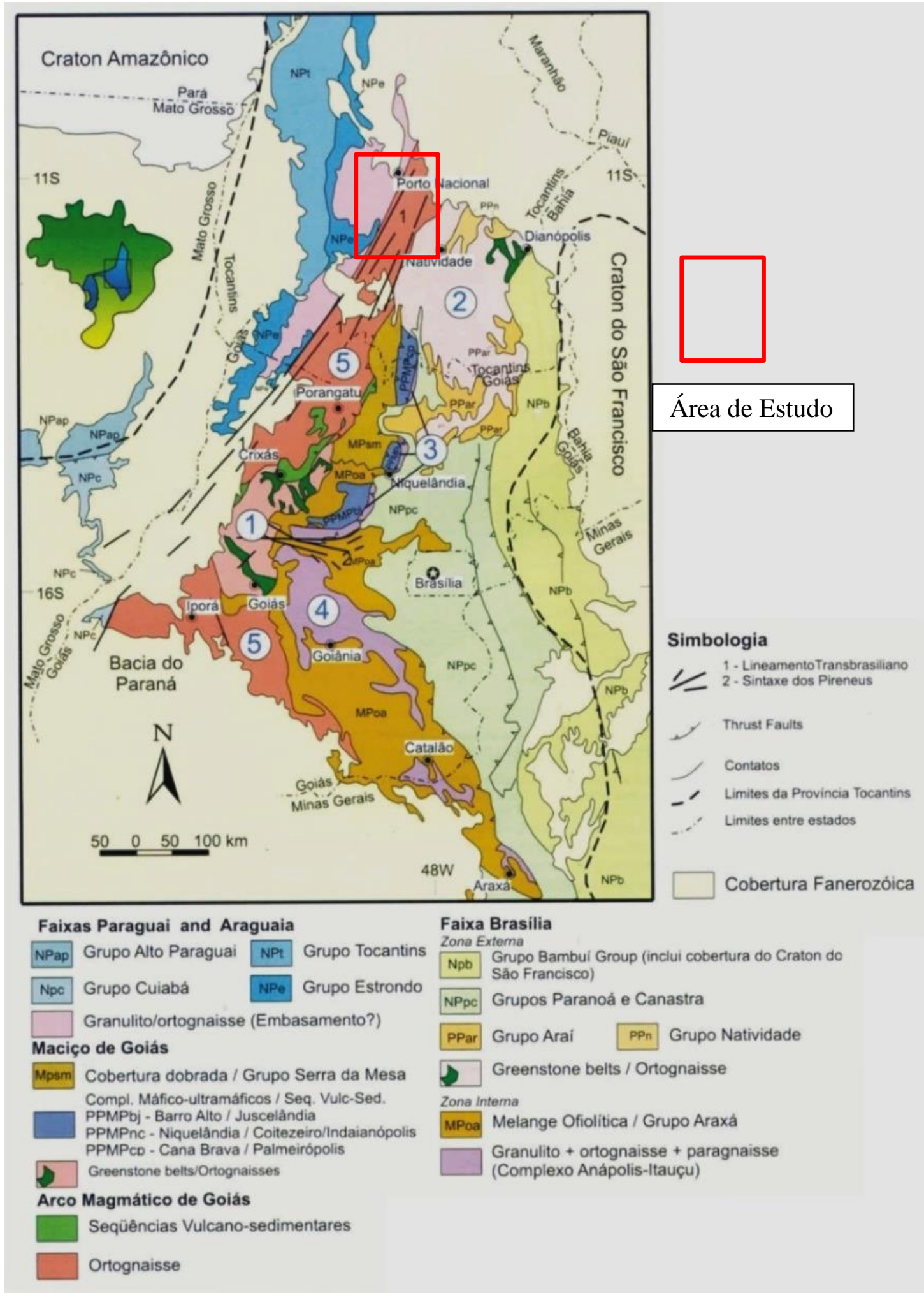

Fig. 3.1 - Esboço da compartimentação tectônica da da porção centro-leste Província Tocantins, conforme Pimentel et al. (2000), Pimentel, et al., (2004), com destaque para O Maciço de Goiás, 1 - Bloco arqueano de Crixás-Goiás, 2 Terrenos Paleoproterozóicos de Almas-Natividade, 3 -Complexos máfico-ultramáficos, Faixa Brasília, 4 - Complexo Anápolis-Itauçu, 5 - Arco Magmático de Goiás e Faixas Paraguai e Araguaia. 
Lacerda Filho et al. (1999) e Delgado et al. in Bizzi et al. (2003), apresentaram compartimentação tectônica da Província Tocantins, onde diferenciaram os vários terrenos baseados em suas idades distintas, significado e ambiência tectônica: a) Terrenos de Significado tectônico duvidoso; b) Terreno Granito-Greenstone; c) Remanescentes do Embasamento Arqueano Paleoproterozóico; d) Faixa Móvel Paleoproterozóica; e) Complexos Máfico-Ultramáficos Acamadados; f) Bacia rift Intracontinental paleoproterozíca; g) Remanescentes de Crosta Oceânica; h) Orógenos Brasilianos faixas Brasília, Araguaia e Paraguai e Arco Magmático de Goiás; i) Bacias de Antepaís e Intracratônicas Neoproterozóicas;

\section{1 - Orógeno Brasilia}

A Orógeno Brasília é um sistema orogênico com mais de 1.100 km de comprimento, mostrando vergência estrutural para o Cráton do São Francisco, e com condições metamórficas P e T aumentando progressivamente em direção ao oeste. É uma das maiores e mais bem preservadas faixas orogênicas Neoproterozóicas (Pimentel et al., 2000), onde são claras a evidência de um ciclo de Wilson, com abertura e fechamento de longa duração, (900-630 Ma).

Fuck et al., (1994) distinguem no orógeno 5 domínios principais: maciço de Goiás, a Zona Externa,a Zona Interna com áreas restritas de exposições do seu embasamento granito-gnáissico e Arco magmático de Goiás. Várias outras propostas de compartimentação desse cinturão foram elaboradas, com destaque para: Costa e Angeiras, (1971); Dardenne, (1978) e (2000); Marini, (1981); Pimentel et al.,(2000), muitas destas interpretações foram realizadas com base na intensidade dos processos deformacionais e metamórficos.

Dardenne, (2000), Cordani et al., (2013) sintetizam a faixa compreendendo:(i) uma espessa pilha metassedimentar neoproterozóica, incluindo os grupos Paranoá, Canastra, Araxá, Ibiá, Vazante e Bambuí, que recobrem o embasamento paleoproterozóico e ocasionalmente o Arqueano na margem ocidental do Cráton do São Francisco, (ii) o Maciço de Goiás, interpretado como um microcontinente (ou terreno siálico alóctone), composto pelos terrenos granito-greenstones arqueanos de Crixás-Goiás e associados a formações proterozoicas e (iii) o Arco Magmático de Goiás um arco intraoceânico juvenil e neoproterozóico.

Valeriano et al., (2004) dividem a Faixa Brasília em dois ramos de orientação distinta e estilos metamórfico-deformacionais contrastantes: a Faixa Brasília Setentrional, de orientação NE, e a Faixa Brasília Meridional, de orientação NW. Esses dois ramos se encontram na altura do paralelo de Brasília formando a Megaflexura dos Pireneus (Araujo Filho 2000; Costa \& Angeiras, 1970), marcada por lineamentos de orientação E-W. 
A geometria resultante da Faixa Brasília apresenta uma pronunciada concavidade voltada para leste, em conformação a uma protuberância no contorno original da margem do paleocontinente São Francisco. Na área da Sintaxe dos Pireneus, estruturas deformacionais presentes da porção setentrional são mais jovens e se sobrepõem às estruturas relacionadas ao empilhamento de nappes observado na porção sul.

A Faixa Brasília Meridional tem um estilo tectônico definido pelo empilhamento de extensas nappes de cavalgamento sub-horizontais formadas predominantemente por rochas da margem passiva sanfranciscana, empurradas em direção ao Cráton do São Francisco por volta de 640 Ma. No seu conjunto, o grau metamórfico e a intensidade da deformação ligada ao cisalhamento de baixo mergulho aumentam consideravelmente, porém não continuamente, da área cratônica, até a zona mais interna da faixa, passando pelas zonas de antepaís e externa. Nos seus estágios mais tardios, a deformação passa para um estilo dominado por dobramentos mais abertos associados a falhas transcorrentes sinistrais de direção NW-SE que acabam por fragmentá-la em segmentos deslocados.

A zona de antepaís da Faixa Brasília é marcada por empurrões rasos e superfícies subhorizontais de décolement que afetam os sedimentos anquimetamórficos plataformais neoproterozóicos do Grupo Bambuí (Dardenne, 2000), com rara ou nenhuma participação de rochas do seu embasamento paleoproterozóico-arqueano (estilo thin skinned). Para leste, esse domínio faz limite gradativo com a área autóctone, virtualmente indeformada, do Grupo Bambuí e de seu embasamento cratônico; a oeste, é recoberto bruscamente pela frente alóctone das nappes de cavalgamento mais externas da porção meridional (Alkmim et al., 1993).

A porção alóctone meridional consiste do empilhamento tectônico de vários terrenos tectono-estratigráficos limitados por importantes superfícies de cavalgamento, a maioria das quais representados majoritariamente por uma unidade litoestratigráfica metassedimentar, tais como os grupos Vazante (inferior), Canastra, Ibiá, Paranoá e Araxá-Andrelândia (superior).

Dados de proveniência de zircão sugerem que algumas dessas unidades (e.g., os grupos Ibiá, Araxá e parte da Serra da Mesa) foram depositadas e deformadas num curto intervalo de tempo entre ca. 650 e 630 Ma (Pimentel et al., 2011; Rodrigues et al., 2008). Além disso, uma mélange ofiolítica neoproterozóico foi identificada no Grupo Araxá como representante de crosta oceânica (Strieder \& Nilson 1992).

Descontinuidades metamórficas podem ocorrer entre terrenos adjacentes, mostrando que o empilhamento tectônico se deu posteriormente ao auge térmico. A intensa deformação torna difícil a tentativa de correlações diretas entre as unidades litoestratigráficas das diferentes escamas. Entretanto, a faciologia sedimentar e as características geoquímicas e geocronológicas apontam para a ambientação de margem passiva. Porções da bacia de fácies mais distais (talude, sopé continental e 
assoalho oceânico) se empilharam tectonicamente sobre as fácies de plataforma mais proximal. As escamas de empurrão (nappes) inferiores apresentam metamorfismo em fácies xisto verde e as superiores tendem a apresentar fácies anfibolito e granulito.

A arquitetura da Faixa Brasília Setentrional por sua vez, é marcada pela existência de vários compartimentos nos quais variam, substancialmente, os materiais envolvidos, os graus de metamorfismo, além dos estilos estruturais e deformação, em escala de faixa de dobramento, que a distingue, da porção sul.

Seus limites são estabelecidos com o Arco Magmático de Goiás e o Maciço de Goiás, pela estrutura de escala regional, denominada Sistema de Falhas Rio Maranhão (Fonseca, 1996). Reconhecida inicialmente por Barbosa et al., (1969). Constitui-se um expressivo cavalgamento que se estende de norte do Distrito Federal, até a altura da confluência dos rios Paranã e Maranhão. Na verdade, tal estrutura possui geometria e cinemática mais complexas, configurando-se como uma superfície de cavalgamento que descreve curvaturas sintaxiais e antitaxiais, com movimentos desde reversos frontais a oblíquos, com cinemática seja dextral ou sinistral.

O Maciço de Goiás é um fragmento continental relativamente pequeno que colidiu contra a margem ocidental sanfranciscana e que apresenta evolução crustal marcadamente longeva e complexa. Está composto por seis complexos de ortognaisses e cinco greenstone belts metamórficos de baixo grau, com idades arqueanas e paleoproterozóicas. Na sua parte norte afloram os complexos de Hidrolina, Moquém, Caimar e Anta e alojam os greenstone-belts de Crixás, Pilar de Goiás e Guarinos e outros menores. Ao sul estão os complexos de Caiçara e Uvá e os greenstone-belts os greenstone-belts de Serra de Santa Rita e Faina. Dados recentes de Jost et al., (2010; 2013), indicam o Maciço de Goiás como uma parte exótica e alóctone que foi amalgamada à província durante os estágios finais da orogenia. Segundo estes autores consistem nas rochas mais antigas, cujos protolitos são tonalitos-e granodioritos e dioritos polideformados que apresentam a idade de cristalização de 3040 Ma a 2930 Ma.

Os mais novos são compostos por tonalitos, monzogranitos e corpos tabulares granodioritos formados entre 2876 e 2846 Ma e que alguns de seus complexos foram formados, pelo menos, durante duas fases magmáticas e como segmentos crustais e independentes. As porções mais jovens indicam idades paleoproterozóicas e a eventos Riacianos no Maciço de Goiás.

Importante retrabalhamento durante paleoproterozóico (ca. 2,2 - 2,0 Ga) produziu magmatismo granítico e sequências supracrustais. Na parte norte do Maciço de Goiás, sucessões vulcanossedimentares (Juscelândia, Palmeirópolis, Indaianópolis) em alto grau metamórfico contêm rochas metavulcânicas bimodais com características geoquímicas anorogênicas, datadas em 1,3-1,25 Ga (Pimentel et al., 2003; Della Giustina et al., 2009). Essas rochas são o registro de um novo evento 
tafrogenético preservado no maciço, que pode estar relacionado à abertura precoce de um oceano. Essas rochas supracrustais recobrem tectonicamente três volumosos complexos máfico-ultramáficos diferenciados metamorfizados em fácies granulito (Cana Brava, Barro Alto, Niquelândia).

Estes complexos resultaram da cristalização de câmaras magmáticas básicas, marcadas por controvérsias quanto à sua idade de cristalização. Recentemente, datações U-Pb SHRIMP em zircão (Pimentel et al., 2003) forneceram idades de cristalização em 797 Ma e do metamorfismo granulítico em $770 \mathrm{Ma}$, as últimas confirmando as datações U-Pb (zircão) obtidas por Ferreira Filho et al., (1994). O metamorfismo granulítico de 770 Ma é indicativo de evento orogênico precoce do neoproterozóico, parcialmente preservado no Maciço de Goiás, porém geralmente obliterado pelos eventos metamórficos principais ocorridos entre 650-600 Ma, relacionados aos episódios colisionais que estruturaram toda a Faixa Brasília.

O Arco Magmático de Goiás (Pimentel \& Fuck, 1992; Pimentel et al., 1996; 1998; 2000) se estende desde a região de Arenópolis e Bom Jardim de Goiás até Porangatu-Mara Rosa em Goiás, ocupando a porção mais ocidental da Faixa Brasília. Representa o testemunho de uma crosta juvenil que registra a abertura e fechamento de um grande domínio oceânico entre paleocontinentes Amazônico e São Francisco-Congo pelo menos entre 900 a 600 Ma. Na sua fase pré-colisional, houve subducção de litosfera oceânica e desenvolveu rochas plutônicas de arcos de ilhas e cordilheiranos, associados a outros gnaisses representantes de seqüências vulcanossedimentares.

O Arco Magmático de Goiás é dividido em arco meridional e setentrional. A porção norte é denominada de Arco de Mara Rosa que compreende um arco de ilha juvenil de idade 900-800 Ma (Pimentel \& Fuck, 1992; Laux et al., 2005) e um arco continental mais jovem chamado se Arco de Santa Terezinha de Goiás com seqüências vulcanossedimentares de idade 670-630 Ma (Junges et al.,2002; Fuck et al., 2002, 2006). O arco juvenil possui em suas unidades toleíticas e cálcioalcalina razões isotópicas $\mathrm{Sr}^{87} / \mathrm{Sr}^{86}$ iniciais baixas e valores $\varepsilon N d$ positivas com idade modelo $\mathrm{T}_{\mathrm{DM}}$ principalmente entre 0,8 e 1,1 Ga (Laux et al. 2005). As associaçoes de arco mais novas tem valores $\varepsilon_{\mathrm{Nd}}(\mathrm{T})$ entre $+2,8$ e $-15,1$, sendo a maioria das rochas com $\varepsilon N d$ negativo, levando os autores a concluir pela provável formação em margem continental ativa no final da orogenia Brasiliana e pelo envolvimento de crosta continental mais antiga para este evento.

A predominancia de composição calci-alcalina dessas rochas magmáticas indica a ação de contínuos processos relacionados à subducção. Acrescentam Dantas et al (2007), que na região setentrional do arco as rochas plutônicas são peraluminosas, mas com assinatura isotópica de material juvenil relacionado a evolução de arcos. Citam idades modelo $\mathrm{T}_{\mathrm{DM}}$ variando entre 1.5 a $1.2 \mathrm{Ga}$, contudo, uma maior participação de material derivado de crosta continental antiga é misturada às rochas juvenis, refletindo idade modelo $\mathrm{T}_{\mathrm{DM}}$ entre 2,6 e 1,7 Ga. Apõem ainda a presença de rochas 
máficas e ultramáficas em faixas alongadas e deformadas interpretadas como restos de crosta oceânica estirada e colocada de forma descontinua ao longo do Lineamento Transbrasiliano.

Chiarini (2007), em interpretações aerogeofísicas de alta resolução e de mapeamento geológico propõe uma arquitetura crustal para região de Porangatu caracterizando-a por um arranjo de blocos litosféricos, com características isotópicas e geocronológicas distintas e adjacentes, limitados por um regime tectônico convergente oblíquo, associado ao Lineamento Transbrasiliano (LTB), considerada a "cicatriz" de uma zona de sutura colisional. Estes blocos litosféricos compõem o Complexo Arqueano Serra Azul, Complexo Porangatu-Novo Planalto e terrenos associados ao Arco Magmático de Mara Rosa.

O Complexo Porangatu - Novo Planalto é representado por gnaisses tonalíticos a graníticos com idades U-Pb em zircão em torno de 570 a $530 \mathrm{Ma}$, sendo proposta uma história tectônica envolvendo maior complexidade para o sistema de arco magmático. Além, destas considerações, Chiarini (2007) discriminou as séries da magnetita e da ilmenita (Ishihara 1977; 2007), como indicativa de evolução de um sistema de arco magmático, identificando uma zonação bipolar de domínios de susceptibilidade magnética, indicando pouca contaminação crustal, gerados em ambiente de arco de ilhas intraoceânico entre 890 e 800 Ma e estágio entre 660 e 600 Ma mais evoluído do sistema de arco magmático com contribuição crustal.

Estudos geofísicos da crosta e litosfera profundas usando tomografia sísmica (Assumpção et al., 2004, Feng et al., 2007), bem como refração sísmica profunda (Soares et al., 2006) foram realizadas ao longo do Arco Magmático de Goiás, onde detecta-se uma grande anomalia positiva Bouguer. A interpretação sugere uma densa litosfera mantélica subjacente ao arco magmático, onde a crosta apresenta 36 - $38 \mathrm{~km}$ de espessura. Para o leste, a espessura da crosta aumenta a $43 \mathrm{~km}$ abaixo da Faixa Brasília e parte do Cráton do São Francisco. Em sua porção ocidental, dados sismológicos mostram abrupta passagem do Arco Magamatico de Goiás e a Faixa Araguaia e Cráton Amazônico. Tal estrutura é considerada o resultado da duplicação de parte inferior da paleoplaca Amazônica durante o final da subducção neoproterozóica abaixo do Arco Magmático de Goiás (Ventura et al., 2011).

Dados indicam que o principal evento de subducção terminou em 630-600 Ma, e que o principal pico metamórfico regional, ocorreu entre 650-630 Ma, conforme registrado pelos granulitos do Complexo Anápolis- Itauçu (Piuzana et al., 2003, Della Giustina et al., 2009), bem como por várias outras unidades de rocha da Faixa Brasília (Baldwin \& Brown, 2008). Neste complexo safirinas dos granulitos indicam o metamorfismo em UHT e zircão marcam as idades U-Pb metamórficas de 650 Ma, que são grosseiramente contemporâneas, a colocação dos complexos máficoultramáficas, representando assim, o núcleo metamórfico do orógeno Brasília. 


\section{2 - Orógeno Araguaia}

O Cinturão Araguaia (Almeida et al., 1984), (fig. 3.1) localiza-se na parte setentrional da Província Tocantins. Apresenta direção geral N-S e mede aproximadamente $1.000 \mathrm{~km}$ de extensão e cerca de $150 \mathrm{~km}$ de largura, ocorre desde a região de São Miguel do Araguaia, no noroeste de Goiás, onde é recoberto pelos sedimentos da Bacia do Bananal até o extremo norte do Estado de Tocantins e justapõem-se à margem oriental do Cráton Amazonas. A leste é recoberto pelas rochas sedimentares da Bacia do Parnaíba, enquanto a oeste as rochas metassedimentares dessa faixa apresentam lâminas de empurrão sobre o Cráton Amazônico.

Suas unidades estratigráficas exibem principalmente uma estruturação norte-sul com mergulhos geralmente suaves para leste e são intensamente deformadas em regime dúctil e compressivo, causando imbricações das unidades basais, a leste, sobre as de topo a oeste. Todas as formações sofreram os efeitos de deformação progressiva. Em cada unidade, diferentes padrões ficaram registrados e correspondem às mudanças no caráter do fluxo e nível crustal onde estas rochas estavam posicionadas quando foram submetidas aos esforços compressivos. A deformação sugere encurtamento crustal e transporte tectônico com colisão obliqua a transversa conforme indica as lineações de estiramento mineral para NW. A sul são associadas por zonas de cisalhamento transcorrentes e de alto ângulo de direção NE/SW que limitam os domínios estruturais das unidades litodêmicas da Faixa Araguaia com a Faixa Brasília na zona do Lineamento Transbrasiliano, (Schobbenhaus, 1975).

Os processos metamórficos variam desde fácies anfibolito a xisto-verde e retratam as diferentes posições crustais de seus conjuntos estratigráficos, diminuindo o grau metamórfico de leste para oeste. Geralmente fazem contato por zonas de falhas contracionais, quando o contato não é tectônico é de difícil reconhecimento à estratigrafia e ordenação original e pouco se observa das discordâncias, sejam erosivas, angulares e/ou inconformidades.

Rochas máficas e ultramáficas estão associadas tanto com o embasamento, quanto com rochas supracrustais, principalmente no domínio ocidental. Peridotitos e dunitos serpentinizados, com cromita (Koutschoubey e Hieronimus, 2005; Teixeira, 1996), estão associados com chert e jaspilito. Ocorrências adicionais de pillows-lavas de basaltos são notadas (Souza \& Moreton 1995), acrescentando a noção de que esses corpos são remanescentes de complexos ofiolíticos. Idades das pilhas supracrustais aproximam-se em torno de 730 a 700 Ma. Idade de metamorfismo é preliminarmente 
definido pela $\mathrm{Pb}-\mathrm{Pb}$ dados zircão de $655 \pm 24 \mathrm{Ma}$ (Moura \& Gaudette, 1993) para o colocação de granitos sintectônica, além de plútons alcalinos das suítes Monte Santo e Serra da Estrela.

Soma-se ao entendimento desta faixa o trabalho de Paixão (2008), identificando lascas e corpos de origem oceânica na Faixa Araguaia e registrando-os como corpos ofiolíticos, o Complexo Quatipuru e o Complexo Morro do Agostinho, oriundos de processos de obducção desta litosfera oceânica e marcadores de zonas de sutura na amalgamação do paleocontinente Gondwana Oeste.

Paixão (2008) fornece dados isotópicos de Sm-Nd que corroboram o caráter MORB desta seqüência ofiolítica, dado por valores positivos de $\varepsilon N d$ de basaltos $\left(\varepsilon_{\mathrm{Nd}}+5\right)$ e diques gabróicos $\left(\varepsilon_{\mathrm{Nd}}\right.$ $\pm 6,7)$ que cortam os peridotitos. Tais diques foram utilizados na obtenção de uma idade isocrônica Sm-Nd de 757 49 Ma, que marca o estágio de oceanização da Faixa Araguaia.

Lima (2008) identificaram outros tipos de intrusões acamadadas máfica-ultramáficas na Faixa Araguaia, um grupo toleítico com tendência ao fraccionamento que produziram corpoas acamadados com concórdia U-Pb com idade de $526 \pm 5$ Ma e idades $\mathrm{T}_{\mathrm{DM}}$ altamente variável e $\varepsilon N d$ negativas. Um segundo grupo de rochas ultramáficas com fraccionamento muito limitado, apresenta dados Sm-Nd altamente dispersos e negativos.

Além destes é comum dentro da Faixa encontrar-se remanescentes de embasamento Arqueano/Paleoproterozóico e associações graníticas neoproterozoicas sin- pós-colisionais e anorogênicas. Na porção norte da Faixa Araguaia, individualiza-se pequenas porções do embasamento, representadas pelos domos gnáissicos Colméia, Lontra e Xambioá, o primeiro (Complexo Colméia), com idades Pb-Pb de 2.85 e 2.84 Ga (Moura e Gaudette, 1999; Moura e Souza, 1996), a sul o embasamento da faixa aflora representada como uma unidade alóctone, o Complexo Rio dos Mangues.

Gorayeb et al., (2013) identifica balizados ao longo do Lineamento Transbrasiliano a Suíte Intrusiva Lajeado que apresenta afinidades metaluminosas a levemente peraluminosas com características geoquímicas semelhantes aos granitos tipo A, abrangendo idades entre 552 e 545 Ma e idade modelo variando entre 2.1 e $1.7 \mathrm{Ga}$ e $\varepsilon_{\mathrm{Nd}}(\mathrm{T} 0,55 \mathrm{Ga})$ negativo com valores entre -10 e -13 e relacionados a um evento tectônico extensional / transtensional crustal no final do Neoproterozóico.

\section{3 - Orógeno Paraguai}

O Orógeno Paraguai, Almeida (1965) é uma unidade geotectônica Brasiliana-Pan-Africana de destaque da Provincia Tocantins e estende-se por aproximadamente $1.200 \mathrm{~km}$. Compõe um cinturão de dobramentos polifásicos, afetado pelo ciclo tectônico Brasiliano, com forma convexa, constituído de rochas metassedimentares dobradas e metamorfizadas que, em direção ao Cráton 
Amazônico, gradam progressivamente a coberturas sedimentares, em parte, contemporâneas e estruturalmente onduladas, falhadas (Alvarenga \&Trompette, 1993).

Alvarenga e Trompette (1993) citam que: “a Faixa Paraguai pode ser interpretada como resultado de uma orogênese de colisão com o desenvolvimento completo do ciclo de Wilson ou como o fechamento de um aulacógeno ou rift intracontinental, possivelmente com reduzida oceanização". Citam ainda: "que a faixa evoluiu e culminou com um choque das duas massas continentais representadas pelos Cráton Amazonas e o Maciço Central de Goiás. O final do processo resultante do fechamento do Oceano do Brasiliano foi acompanhado de intrusões graníticas pós-tectônicas com idades em torno de $500 \mathrm{Ma}$ ".

As conclusões de Alvarenga e Trompette (1993) estão corretas, no entanto diferem da porção ocidental desta faixa onde se encontram os relictos dos sistemas rifts iniciais e seu vulcanismo. A este episódio precursor, sobrepõem-se eventos orogenéticos com intenso encurtamento crustal, soerguimento e exumação da bacia, seguidas de sua inversão tectônica e fechamento, formando um extenso cinturão desenvolvido às margens colisionais do Cráton Amazônico e Paranapanema durante a consolidação do W-Gondwana. Neste ponto ocorre uma diferença fundamental, a vergência de todas as unidades é inversa à sua porção ocidental (Silva et al., 2014), não se tratando apenas de uma questão de back-thrust conforme apregoado por Silva (1990), mas de uma inversão causada pelo choque de uma área cratônica.

Orógeno Paraguai segundo Brito Neves, Campos Neto e Fuck (1999) são marcados pelas estruturas planares, e uma distribuição geralmente em leque das foliações de plano axial, com o aumento de oeste para o leste, do metamorfismo e deformações. Dados geocronológicos e paleontológicos disponíveis indicam que no final do Neoproterozóico-Cambriano as fases de sedimentação, foram seguidas por fechamento e inversão (colisão) da bacia entre 550-500 Ma (Trompette, 1994), mas esta ainda precisa ser redefinida. As unidades estratigráficas apresentam características litológicas distintas, mas metamorfismo, deformação e idades geocronológicas comuns, ocorrendo predominantemente, a intercalação original de seus litodemas e/ou a repetição tectônica em dobras assimétricas fechadas, zonas de cisalhamento estreitas e/ou imbricação tectônica de rampas obliquas são típicas da Faixa Paraguai.

Magmatismo granítico pós-orogênico e intrusões alcalinas são encontradas. Hasui e Almeida (1970), com base em datações K-Ar em muscovita recristalizada em filito do Grupo Cuiabá, atribuíram idade mínima de 549 Ma. Em datação pelo mesmo método no granito São Vicente e nos Pegmatitos Miranda, intrusivos no Grupo Cuiabá, os referidos autores obtiveram idades de 503 e 550 Ma, respectivamente. 
Geraldes et al. (2003) apresentam idades ${ }^{40} \mathrm{Ar} /{ }^{39} \mathrm{Ar}$ em torno de $540 \mathrm{Ma}$ em micas desenvolvidas na zona de cisalhamento do Araés, na região de Nova Xavantina, que interpretam como representativas do pico de metamorfismo de um evento colisional relacionada à colagem do oeste do Gondwana no continente Sul Americano.

A presença de gabros e metabasaltos nas rochas da região de Nova Xavantina, apresentando valores de $\varepsilon \mathrm{Nd}$ positivos e assinatura geoquímica semelhante do tipo MORB, sugere envolvimento de crosta oceânica no desenvolvimento da Faixa Paraguai (Dantas e Martinelli, 2003). 


\section{Capítulo 4 - Geologia Estrutural}

\section{1 - Introdução}

A área de tese exibe uma grande variedade de terrenos geológicos, esta diversidade é correspondente à heterogeneidade estrutural que apresenta características distintas, com variação em estilo e padrões de interferência que se superpõem. Apesar desta complexidade os padrões podem ser isolados de forma mais homogênea, proporcionando a análise de domínios e regimes deformacionais, de rochas em um mesmo nível crustal, ou por estarem submetidos a um campo tensional similar ou em comum.

As estruturas e as assembleias geológicas regionais indicam processos acrescionários e colisionais com predominância de regimes tectônicos compressionais, transpressionais e transcorrentes, além de cavalgamentos e imbricações de unidades com dupla vergência.

As principais feições estruturais regionais reconhecidas nestes padrões são: o Lineamento Transbrasiliano, a geossutura Tocantins-Araguaia (Sistema Compressional Xambioá-Gurupi), o Lineamento Maranhão-Paranã, a Falha do Rio dos Bois que se inter-relacionam nesta área.

\subsubsection{Sistema de Falhas Transbrasilianas}

Schobbenhaus Filho et al., (1975), em sua citação original não questionaram a origem, ou significado dos lineamentos, caracterizando-os apenas como um sistema de falhas de direção principal NE-SW e direção secundária N-S e que estes lineamentos já haviam sido referidos localmente por Northfleet et al., (1969), como Sistema de falhas do Centro-Leste de Mato Grosso. Esta feição só veio a ser mais bem definida por Cunha et al., (1981) no projeto RADAMBRASIL onde a descreveram como uma faixa intensamente falhada do território brasileiro, representante de uma feição estrutural com mais de $2700 \mathrm{~km}$ de extensão, figura 4.1 .

Os estudos acompanharam o desenvolvimento de técnicas geológicas, principalmente referente à geologia estrutural, a novos conceitos sobre zonas de cisalhamento (shear zones) e a geometria do fluxo dúctil em rochas, assim como dados aerogeofísicos de maior detalhe.

Durante a década de 80 e inicio dos anos 90, Costa, Hasui e Haralyi (1988); Costa, Hasui e Gorayeb (1988); Costa e Hasui (1988); Machado et al., (1981), reconheceram o significado tectônico do sistema de falhas, caracterizando-as como zonas de cisalhamento transcorrentes, confirmadas também, em levantamentos aerogeofísicos. À exceção de Hasui (2010), Hasui \& Ponçano (1978), Assumpção et al.,(1986) a maioria dos autores concordam com a cinemática preferencial dextral. 


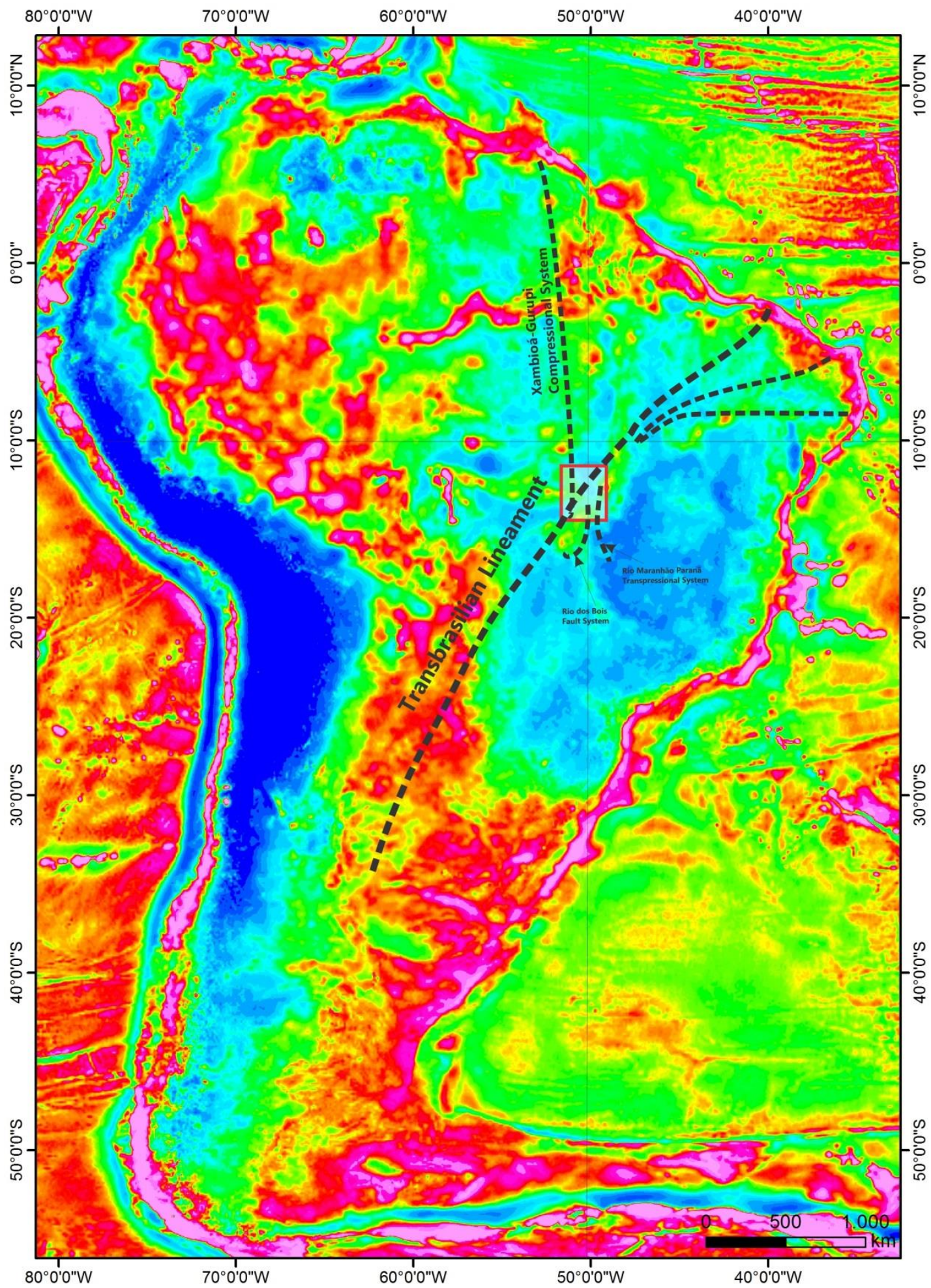

Figura 4.1 - Imagem Gravimétrica da América do Sul, contexto estrutural e influência do Lineamento Transbrasiliano, área retangular representa área de interesse de tese. 
A área de tese insere-se no domínio do Lineamento Transbrasiliano (Schobbenhaus Filho et al., 1975). Esta feição estrutural separa as faixas Brasília e Araguaia, no âmbito da Província Tocantins e em particular na porção central da área de estudo.

O sistema Transbrasiliano é entendido como uma megafeição continental resultado dos deslocamentos laterais, durante e após, a colisão envolvendo massas continentais. Forma um imbricado sistema de falhas transcorrentes dúcteis e subverticais dextrais em sua maioria de direção N30 ${ }^{0} \mathrm{E}$ e limitam domínios estruturais distintos na Província Tocantins.

Este sistema é também, indicado como responsável pelo controle de inúmeros depósitos minerais, Lacerda Filho et al., (1999). A sua evolução são assinaladas sucessivas reativações que refletem processos de fragmentação crustal e são responsáveis pela implantação de bacias ensiálicas fanerozóicas, na região de sua influência.

Monitoramento do Observatório de Sismologia do Instituto de Geociências da UnB indica que ao longo destas falhas, ocorre uma zona ainda ativa, denominada de faixa Sísmica GoiásTocantins. Trata-se de uma notável feição sismotectônica geradora de eventos com magnitudes 4.0, distribuídos ao longo de um "trend" NE-SW, com dimensões aproximadas de 700 km de extensão e $200 \mathrm{~km}$ de largura.

$\mathrm{Na}$ área de interesse o Sistema Transbrasiliano é representado através de uma série de zonas de cisalhamento e falhas transcorrentes e inversas regionais que recebem as seguintes denominações locais: Falha de Talismã; Falha do Rio dos Bois, Falha de Serra Azul e Falha da Água Bonita, todas de direção NE e possuem quilômetros de largura em área de influência.

\subsubsection{Sistema Compressional Xambioá-Gurupi}

Na porção setentrional da Orógeno Araguaia este sistema de falhas foi estudado por Trouw et al. (1976), Hasui e Matta (1992) a qual denominaram de zona de cisalhamento Tucuruí. Esta faixa compreende uma zona de cavalgamentos do Orógeno Araguaia em direção à borda leste do Cráton Amazônico e está caracterizada também, pelo alinhamento de rochas ultrabásicas e básicas (ofiolitos). Almeida (1974), já havia delimitado esta zona como uma sutura ou falha convexa na borda oriental do Cráton Amazônico e a designou de Sutura Marginal Tocantins-Araguaia.

Souza e Moreton (1995) descrevem esforços progressivos e tangenciais com vergência para o Cráton Amazônico desenvolvendo superfícies de deslizamentos e descolamentos de baixo ângulo. Estas rampas frontais marcam o limite de unidades petrotectônicas e se estendem ao longo de todo Orógeno Araguaia, de seu extremo norte a sul, Delgado et al., (2003), denominou esta zona de Sistema Compressional Xambioá-Gurupi. 
Sadowski e Campanha (2004) classificam este sistema de falhas como uma feição de direção aproximadamente NS com vergência para oeste, de mais de $400 \mathrm{~km}$ de extensão e que posicionou rochas máfico-ultramáficas e filitos da Orógeno Araguaia sobre arenitos e ardósias da cobertura cratônica. A falha é considerada, pós-metamórfica e neoproterozóica com base em uma datação $\mathrm{K} / \mathrm{Ar}$ de $510 \mathrm{Ma}$ em um basalto inserido na zona de cisalhamento. A espessura da zona de cisalhamento é de cerca de $200 \mathrm{~m}$.

$\mathrm{Na}$ área de estudo este sistema de falhas está representado na porção noroeste, caracterizando um domínio tectônico próprio, transpressional sob regime dúctil e dúctil rúptil que formam dobras assimétricas recumbentes e de falhas inversas com vergência em direção a oeste. Está registrado nas rochas de embasamento (Complexo Rio dos Mangues) e nas formações metassedimentares do Grupo Baixo Araguaia, granitos da Suíte Aliança apresentando ainda importância econômica, por conter importantes mineralizações de quartzo e gemas na região.

\subsubsection{Sistema Transpressional Rio Maranhão-Paranã}

Barbosa et al. (1969) descreveram esse Sistema de falhas no Projeto Brasília como Falhas Rio Maranhão e caracterizaram como uma descontinuidade geológica cujo traçado pode ser observado ao longo de mais de $300 \mathrm{Km}$ desde a região de Padre Bernardo em Goiás, até a confluência dos rios Tocantins e Paraná no extremo leste da área de estudo.

Fonseca et al (1995) propõe para oeste deste sistema, onde predominam rochas do Grupo Serra da Mesa, uma deformação polifásica com padrão de dobras flexural típica de zonas internas de faixas móveis. A leste, segundo esses autores, uma segunda fase é apenas local e decorre da interferência de sistemas transcorrentes com sistemas frontais. Argumentam ainda que a leste do sistema Rio Maranhão, as rochas estão na fácies xisto verde (Marini \& Fuck 1981) e, a oeste, na fácies anfibolito e a passagem é balizada pelo rio Tocantins (Fuck \& Marini 1981).

Fonseca et al (1995) citam ainda uma conjugação do Sistema Rio Maranhão com o Sistema Paranã e o Sistema Santa Teresa e outros, oblíquos e/ou transcorrentes de menor expressão, mas de grande importância, na medida em que acomodam grande parte da deformação que compreendem os outros grandes sistemas regionais.

A arquitetura do sistema Rio Maranhão-Paranã e Santa Teresa possuem geometria e cinemática complexas por falhas de empurrão imbricadas e conectadas a descolamentos subhorizontais interestratais. Os dobramentos sempre envolvem em geral, dobras flexurais de deslizamento, com dobras normais ou assimétricas, nas mais variadas escalas. O sistema Transbrasiliano nos limites entre as unidades de arco Neoproterozóicas e o embasamento da Orógeno Brasília podem representar uma fase ou padrões de interferência locais, fruto da nucleação de estruturas variadas ou, ainda, 
resultar de reativação regional de estruturas antigas e herdadas paralelas ao lineamento Transbrasiliano, no qual se insere.

\subsubsection{Falha do Rio dos Bois}

A Falha do Rio dos Bois Outra é uma feição estrutural de relevância e se estende do norte de Goiás ao sul do estado de Tocantins. Esta descontinuidade margeia ou faz contato direto com blocos crustais de evolução e idades distintas, o Maciço de Goiás e o Arco Magmático de Goiás. É marcada por uma falha inversa na região de Mata Azul progredindo para uma zona transpressionada obliqua, integrando e se amoldando em seu limite norte às zonas de transcorrência dextrais ao Sistema Transbrasiliano.

Originalmente foi descrita por Drago et al., (1981), como Falha do Trombas caracterizandoa como uma falha de caráter inverso e que sobrepunha rochas do Complexo Goiano sobre rochas do Grupo Araxá, baseando sua denominação homônima a cidade do norte de Goiás. Ribeiro Filho et al., (1978) durante o Projeto Geologia da Região Pilar -Mara Rosa cita a presença de cianita nas regiões próximas aos falhamentos inversos intensos na região do Rio dos Bois.

Kuyumjian (1994) nomeia esta feição tectônica, caracterizando-a como uma falha de empurrão. a qual rochas supracrustais neoproterozóicas cavalgam sobre terrenos mais antigos. Posteriormente Ventura et al., (2011) em trabalho de caracterização sísmica e gravimétrica reavaliam esta falha e a hierarquizam como Zona de Cisalhamento Rio dos Bois constituindo uma das principais estruturas estruturais regionais que secciona a porção centro leste da Província Tocantins.

\subsection{Análise de Sensores Remotos}

Uma análise das macrofeições estruturais foi realizada em aerofotos, imagens GEOCOVER, LANDSAT, SRTM e RADAR. (figura 4.2). Os lineamentos estruturais traçados pelo método de fotoleitura destacaram cristas, limites de áreas elevadas, setores retilíneos de drenagem, formando áreas com padrões distintos, passíveis de análise de forma quantificada, foram identificados os principais eventos tectônicos, bem como a intensidade da deformação. A análise de distribuição mostra áreas, onde há uma intensa frequência de estruturas localizadas na porção centro-leste em uma faixa $\mathrm{NE}$, formando zonas estruturais homólogas.

Grande parte dos lineamentos concentra-se em estruturas positivas, cristas alongadas e dobradas que constituem o embasamento do Orógeno Brasília, notadamente os litotipos do Grupo Araí e Serra da Mesa. Observam-se também, áreas de baixa concentração na porção centro-setentrional e 
extremidade NW e porções isótropas que ocorrem principalmente associadas a granitos tardi a anorogênicos na posição central da área.

São comuns os registros de grandes lineamentos estruturais, orientados na direção N20 ${ }^{0}$ $30^{0} \mathrm{E}$ e subordinadamente N/S e NW/SE. O traçado NE estende-se por quilômetros de distância, ora contínuo, ora descontínuo, sinuoso, curvilíneo, localmente, interconectando-se para formar um padrão geométrico assimétrico, sigmoidal, figura 4.2.

Marcam as extensas zonas de descontinuidades estruturais, os limites entre o blocos do embasamento do Orógeno Brasília e o arco magmático, bem como as intensas zonas de cisalhamento dúcteis e falhas transcorrentes do Sistema Transbrasiliano.

\section{3 - Análise Estrutural}

$\mathrm{Na}$ análise estrutural e guardando-se as devidas proporções cita-se Drago et al., (1981), onde descreveram com muita propriedade: "esboçar uma evolução geológica e tectônica para esta porção sul do Tocantins e admiti-la como correta e conclusiva seria muita pretensão dos que nela trabalharam...".

Apesar de inúmeras complexidades estruturais tem-se a nítida concepção de que a proposta colocada para análise e evolução geotectônica da área, obrigatoriamente tem que ser concebida de

uma forma mobilista e dinâmica. É ciente a complexidade e a importância no contexto geotectônico de justaposição dos orógenos Brasília e Araguaia, a justaposição de blocos de embasamento e arcos magmáticos e deve-se ter a noção de que sua interpretação e a proposta apresentada ainda estão longe de uma conclusão.

O contexto de ciclos e eventos deformacionais é analisado sob a óptica de um processo de interferências de padrões, evolutivo e progressivo para alguns domínios finais identificados. Todos os elementos estruturais f azem parte de pequenos incrementos deformacionais, registrados ao longo de todo neoproterozoico. 




Figura 4.2 - Imagem aerogeofísica com a amplitude de sinal analítico e traçado dos principais lineamentos estruturais e magnéticos.

Ressalta-se a este ponto que as deformações registradas nas rochas das unidades de embasamento Paleoproterozóico são no mínimo coaxiais em relação às neoproterozóicas ou foram totalmente transpostas por estas deformações Brasilianas mais jovens.

As estruturas foram hierarquizadas em função de estilos e geometria, caráter e regime deformacional, das características tectônicas, nível crustal, do campo tensional e fácies metamórficas, 
bem como os indicadores cinemáticos dos terrenos envolvidos. Divididos em seis domínios estruturais, o primeiro mais antigo, relíquiar, mas coaxial aos mais modernos. Os três seguintes fazem parte do contexto neoproterozoico, desde um estágio dúctil de cisalhamento puro de encurtamento crustal, até interferências estruturais de deformação mais tardia de caráter transpressional e transcorrente e de nível crustal profundo. É observado áreas com ausência deformacional, e por fim um estágio tardio e de idade provável Fanerozóico/Paleozóico de caráter eminentemente rúptil.

Destaca-se também, que esta compartimentação em domínios estruturais não é rígida, e o fato de superposição de um domínio sobre outro, não possui relação de exclusividade, o que significa dizer que é freqüente a ocorrência feições localizadas de um domínio mais novo sobre o mais pretérito e que sua separação foi feita em função de seu predomínio.

Estes domínios foram denominados de: A) Domínio Dúctil de Embasamento, caracterizado por estruturas de eventos deformacionais mais antigos, parcial ou totalmente transpostos por sistemas deformacionais mais jovens; B) Domínio Dúctil Compressional Centro-Leste, o qual corresponde a uma área com registro de encurtamento crustal; C) Domínio Dúctil CompressionalTranspressional Oeste, como uma área com eventos de deslocamentos de massa oblíquos e de descolamentos e imbricações de baixo ângulo; D) Domínio Dúctil Transcorrente Central, área marcada por zonas de encurtamento crustal e submetidas a zonas de cisalhamento do tipo strike-slip e de alto angulo. E) Domínio Isótropo marcado por intrusões a pós-orogênicas correspondente a zonas de intrusões tardias e de e sob influencia extensional; F) Domínio Rúptil é o sistema mais jovem e correspondente a zonas de falhas e fraturas de direção NW, sobreposta a todas as unidades estratigráficas.

Os dados são apresentados de forma gráfica em estereogramas, com o percentual de incidência e número de medidas, fotografias, sketchs e bloco diagramas de afloramentos-chave visitados na área, as atitudes foram medidas em DIP e os estereogramas representam as linhas de maior de mergulho e não polos, a concentração máxima marca a área modal dos mergulhos, os planos traçados são os planos destas concentrações mais frequentes em campo, sempre em hemisfério inferior.

\subsection{1 - Domínio Dúctil do Embasamento (Infraestrutura)}

O primeiro domínio ocorre na porção leste e em faixas centrais da área, limitando-se ao Bloco Cavalcante-Natividade Cavalcante e em raras porções do embasamento do Orógeno Araguaia. Caracterizam-se por apresentar duas ou no mínimo três fases deformacionais, das quais as relações de progressão são sugeridas.

A primeira fase é observada pelo desenvolvimento de um bandamento gnáissico localizado, principalmente nas rochas do Complexo Almas Cavalcante (2.2 Ga) e Suíte Aurumina (2.1 Ga). 
Suas feições, em grande parte estão transpostas por processos deformacionais mais jovens, que mascaram ou obliteram as estruturas originais, inclusive na Formação Ticunzal (>2.2 Ga). Ocorre de forma limitada às faixas próximas a descontinuidade Transbrasiliana que separa o bloco do embasamento, das unidades orto e paraderivadas de idade Neoproterozóica.

Geralmente possuem atitudes bem variadas, desde $\mathrm{N} 70^{\circ} \mathrm{W}$ a $N 05^{\circ} \mathrm{W}$ e $\mathrm{N} 15^{\circ} \mathrm{E}$ a $\mathrm{N} 50^{\circ} \mathrm{E}$, com mergulhos baixos a altos para ambos os lados. Este bandamento encontra-se dobrado e transposto por deformações mais jovens. Padrões estruturais dessas rochas são observados na figura 4.3.

A segunda fase impõem sobre as rochas de embasamento outros estilos deformacionais. Observam-se feições de cisalhamento puro evidenciando um forte encurtamento crustal, em regime dúctil e contracional, com a geração de dobras cilíndricas, simétricas a assimétricas, apertadas, de charneira espessada e plano axial subvertical de direção NE/SW, eixos com caimento geralmente oscilando em baixo ângulo para NE e SW, quase sempre em bainhas e rompidas por deformações transcorrentes sobrepostas, (figura 4.4). A idade da deformação é ainda dúbia, e implica numa deformação progressiva e de posicionamento relativo ao ciclo Brasiliano, uma vez que este registro de estende a rochas de idade meso a neoproterozóicas.

Formam planos que dobram as superfícies bandadas e também formam uma foliação muito penetrativa de direção geral $\mathrm{N} 09^{0} \mathrm{E} / 68^{0} \mathrm{NW}$ e $\mathrm{N} 07^{0} \mathrm{~W} / 60^{0} \mathrm{NE}$, apresentando certa similaridade e paralelismo ao evento Transbrasiliano, figuras 4.4 e 4.5. Esta foliação é tanto mais forte quanto mais próxima do contato entre os blocos Paleoproterozóico e Neoproterozóico.

A fase de transcorrência transpõe essas superfícies e é tardia a fase de compressão. Alguns setores indicam transcorrências com certa obliquidade, de forma a manter a foliação na mesma direção, rompendo as estruturas dobradas e gerando uma lineação de estiramento subhorizontal a levemente inclinada para NE de direção $\mathrm{N} 010^{0} \mathrm{~W}-\mathrm{N} 015^{0} \mathrm{E}$ e paralelas aos $\mathrm{L}_{\mathrm{b}}$ da fase de encurtamento. Em geral apresentam cinemática bem marcada e preferencialmente dextral, figura 4.6B. A figura 4.7 é um bloco diagrama compondo diversos afloramentos integrando a deformação observada no Bloco Cavalcante-Natividade Cavalcante, principalmente. 

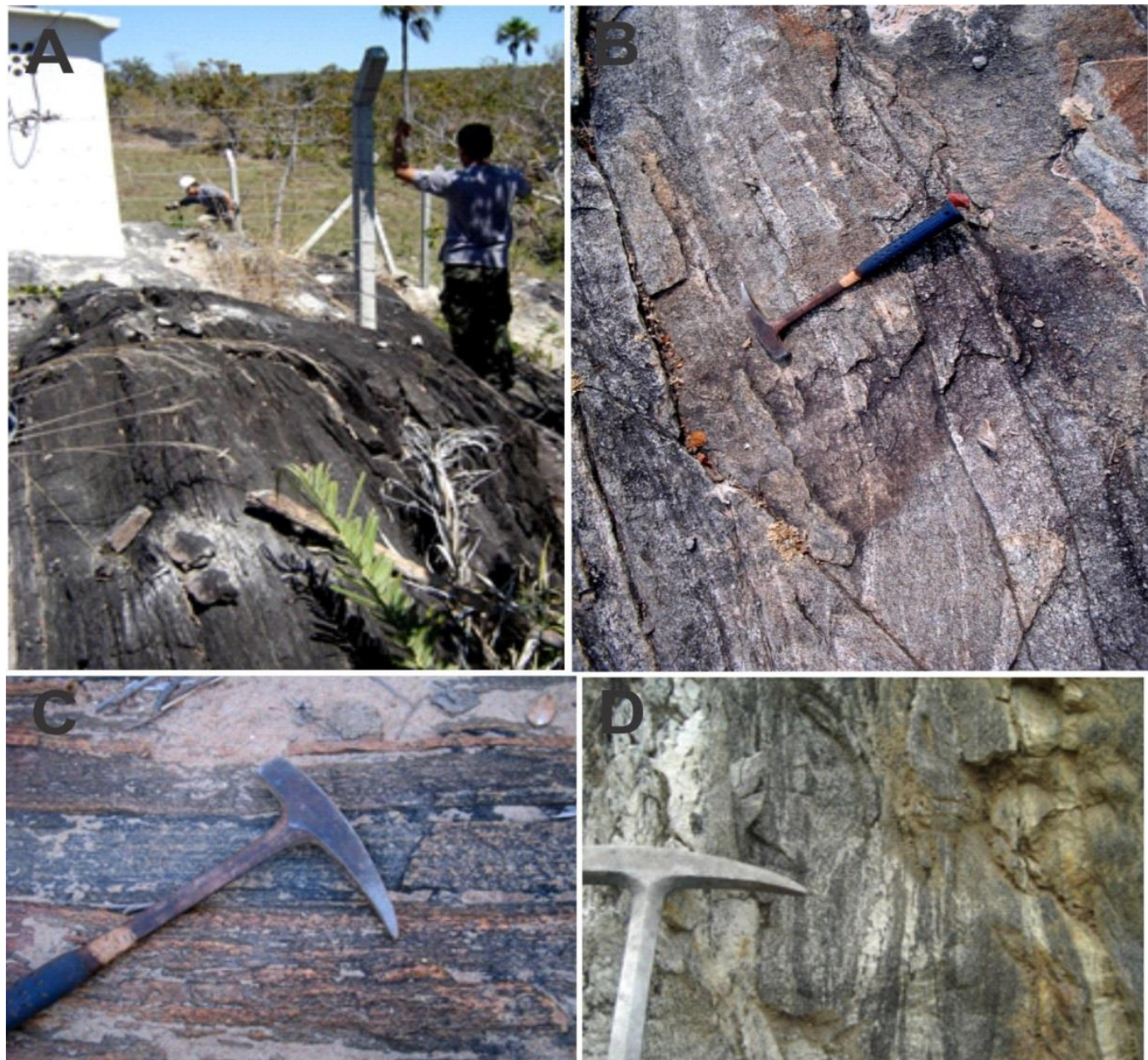

Figura 4,3) A) Aspecto de bandamento relíquiar transposto em alto ângulo em biotita granodiorito gnaisse LL260; B) Detalhe de bandamento dobrado e transposto em granodiorito gnaisse LL226; C) inicio processo gnaissificação em biotita granodiorito (bandas máficas) e injeções graníticas (bandas félsicas-Leucossomas), com deformação paralela sobreposta em LL247; D) Aspecto de bandamento gnáissico dobrado em tonalitos/dioriotos em LL262.
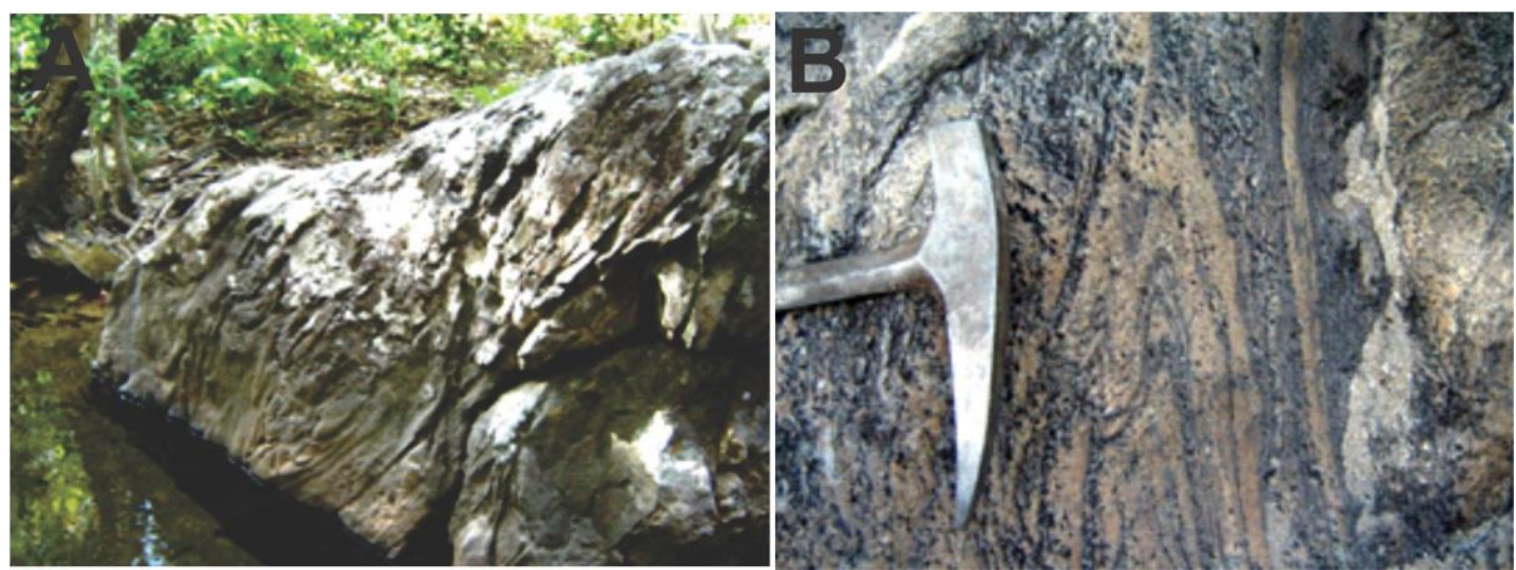

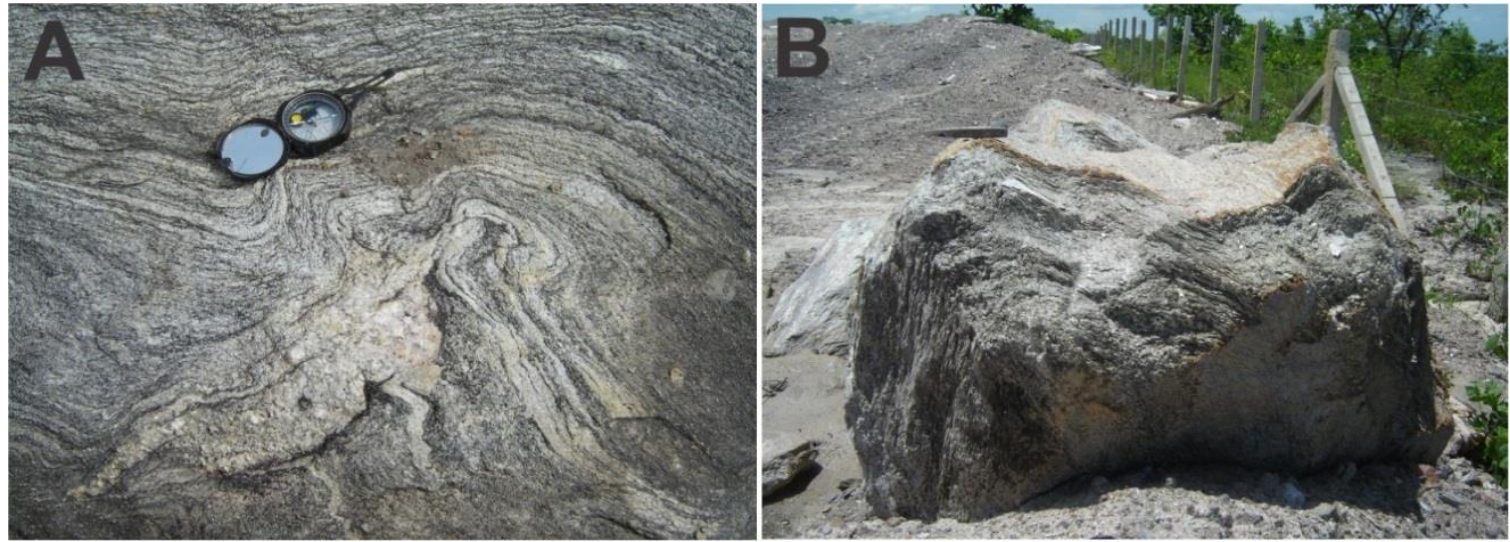

Figura 4.4- A) Aspecto de bandamento relíquiar transposto em alto ângulo em paragnaisses PV143; B) inicio processo gnaissificação em (bandas máficas ricas em biotita) (bandas félsicas dobradasLeucossomas), com deformação paralela sobreposta em PV143; C) Detalhe em planta de bandamento dobrado com aspecto migmatitico em granodiorito gnaisse PV152; D) Aspecto de bandamento gnáissico dobrado em tonalitos/dioriotos estrada Peixe - Paraná, proximidades de LL290a.



Figura 4.5 - A) ) Estereograma das superfícies $\mathrm{Sn}_{2}-\mathrm{Sn}_{3}$, de bandamentos e foliação dobrada em alto ângulo (f2) e transposta (f3), subparalelos a plano axial de dobras geradas em domínio dúctil, Formação Ticunzal, Complexo Almas Cavalcante e Suíte Aurumina (131 medidas). Intersecções de 
planos projetam os eixos $\mathrm{Lb}_{2}$ teóricos relacionados a este domínio B) Lineação de estiramento da fase 3 - Transcorrências a transcorrências obliquas. (31 medidas); C) Veios extensionais provavelmente relacionados à fase de transcorrência, marcando eixo $\tau 1$ máximo aproximado. (17 medidas). Medidas em DIP.
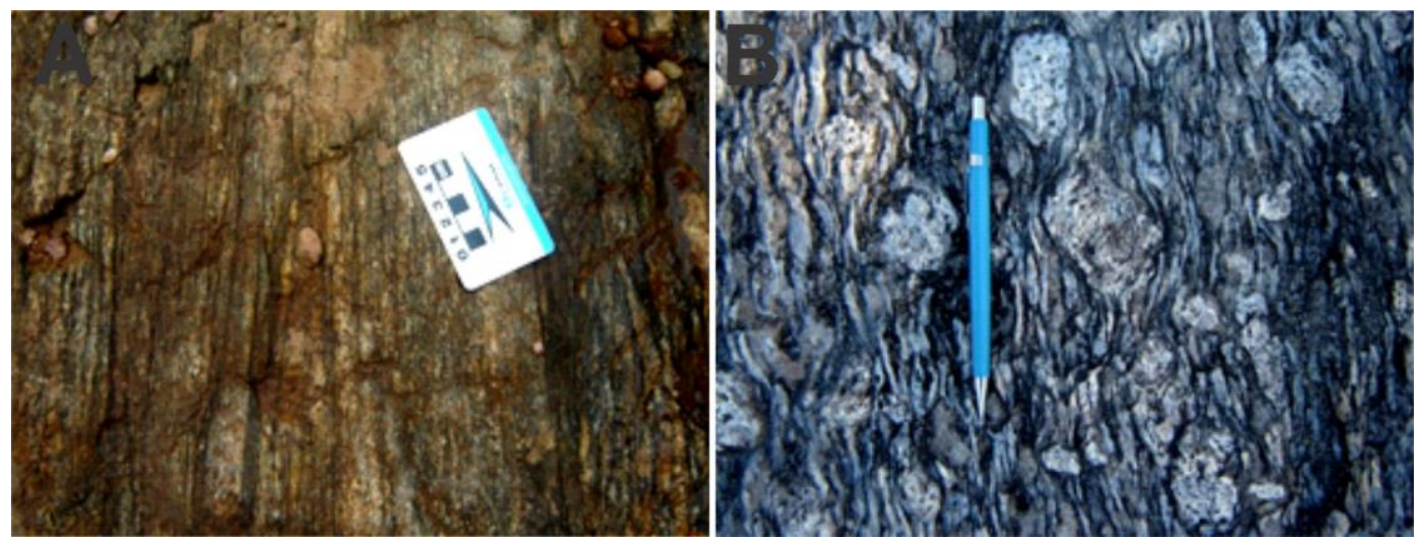

Figura 4.6- A) Aspecto em planta de foliação milonítica da fase de transcorrência do embasamento com direção aproximada $\mathrm{N} 10^{0} \mathrm{E}$, biotita muscovita metatonalitos LL247, e B) em metagranodioritos porfiroclásticos, LL296.

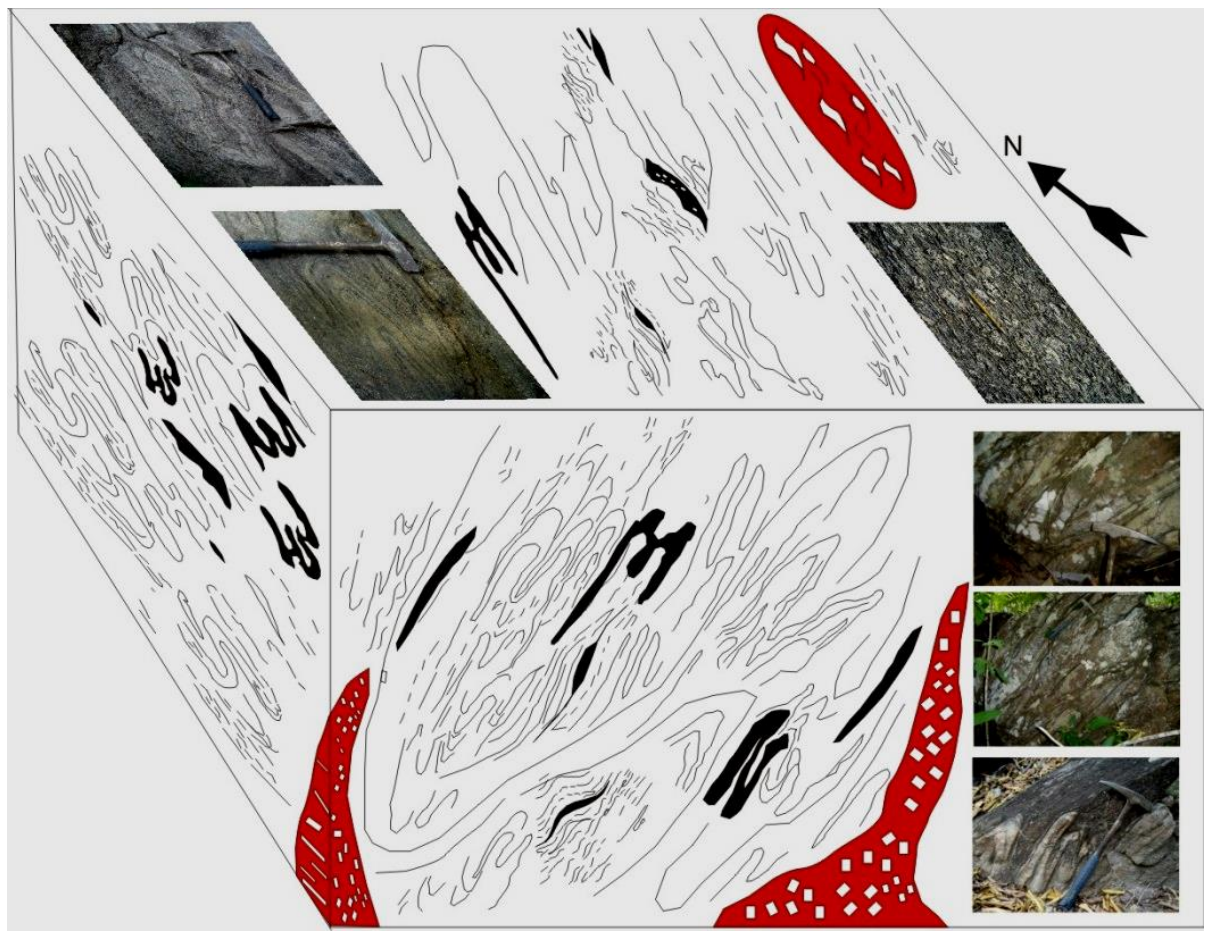

Figura 4.7 - Bloco diagrama com a composição dos afloramentos PV143, LL296 com fotos e sketchs de campo, mostrando as dobras " $\mathrm{M}$ " isoclinais e assimétricas $\mathrm{S}_{2}$, dobras em bainha em planos distintos relacionados à fase de encurtamento crustal e os deslocamentos transcorrentes dextrais na superfície topo relacionadas à fase mais tardia sob cisalhamento simples rompendo as dobras de fase anterior. 


\subsection{2 - Domínio Dúctil Compressional Centro-Leste}

Este domínio está registrado, em maior ou menor escala, em toda área e aflora em maior destaque na porção sudeste. Está assinalado principalmente nas rochas supracrustais do Bloco Cavalcante-Natividade e no Maciço de Goiás no Orógeno Brasília, os grupos Arai, Serra da Mesa, Paranoá e na Sequiência Metavulacanossedimetar de Palmeirópolis. No extremo norte e central também se registra esta deformação, principalmente em rochas supracrustais neoproterozoicas da Formação Monte do Carmo.

Em parte, corresponde também ao Sistema Transpressional Rio Maranhão-Paranã e constitui-se de um amplo sistema de dobras e falhas inversas, desde escala macroscópica a amplas dobras com quilômetros de extensão. Desenvolvem diversos pares de sinclinais e anticlinais, apertadas e de charneira espessadas, muito bem observadas em aerofotos e imagens orbitais. Em geral formam dobras cilíndricas, assimétricas, plano axial inclinado, caimento a baixo ângulo, ou duplo caimento tanto para NE como SW.

Em termos da deformação este setor foi submetido a um regime contracional de forte encurtamento crustal, cuja característica da geometria de fluxo indica cisalhamento puro e cinemática convergente, com vetor predominante em torno de $\mathrm{N}^{\circ} 5^{\circ} \mathrm{W}$, semelhante ao vetor tensional encontrado na infraestrutura do embasamento do Bloco Cavalcante Natividade.

As dobras apresentam tanto características de geração sob fluxo flexural (intraestratos microcristalino), com a formação de uma xistosidade própria, como de deslizamento flexural interestratos, com a formação de corrugações e estruturas tipo mullions. Parte da estratigrafia original ainda fica preservada, no entanto são raros os afloramentos onde se observam estruturas primárias preservadas.

As dobras apresentam geometria inclinada com caimento e orientação média de seu plano axial $\mathrm{N} 08^{0} \mathrm{E} 81^{0} \mathrm{NW}$, subverticais e eixos com duplo caimento, ora para $12^{0} 009^{0} \mathrm{NE}$, ora para $18^{0}$ $182^{0} \mathrm{SW}$. Estes padrões de dobras e eixos podem ser observados nos estereogramas da figura 4.8, medidas em DIP. Em escala de afloramento esses padrões repetem a mesma estrutura fractal, conforme observada na figura 4.9 . 

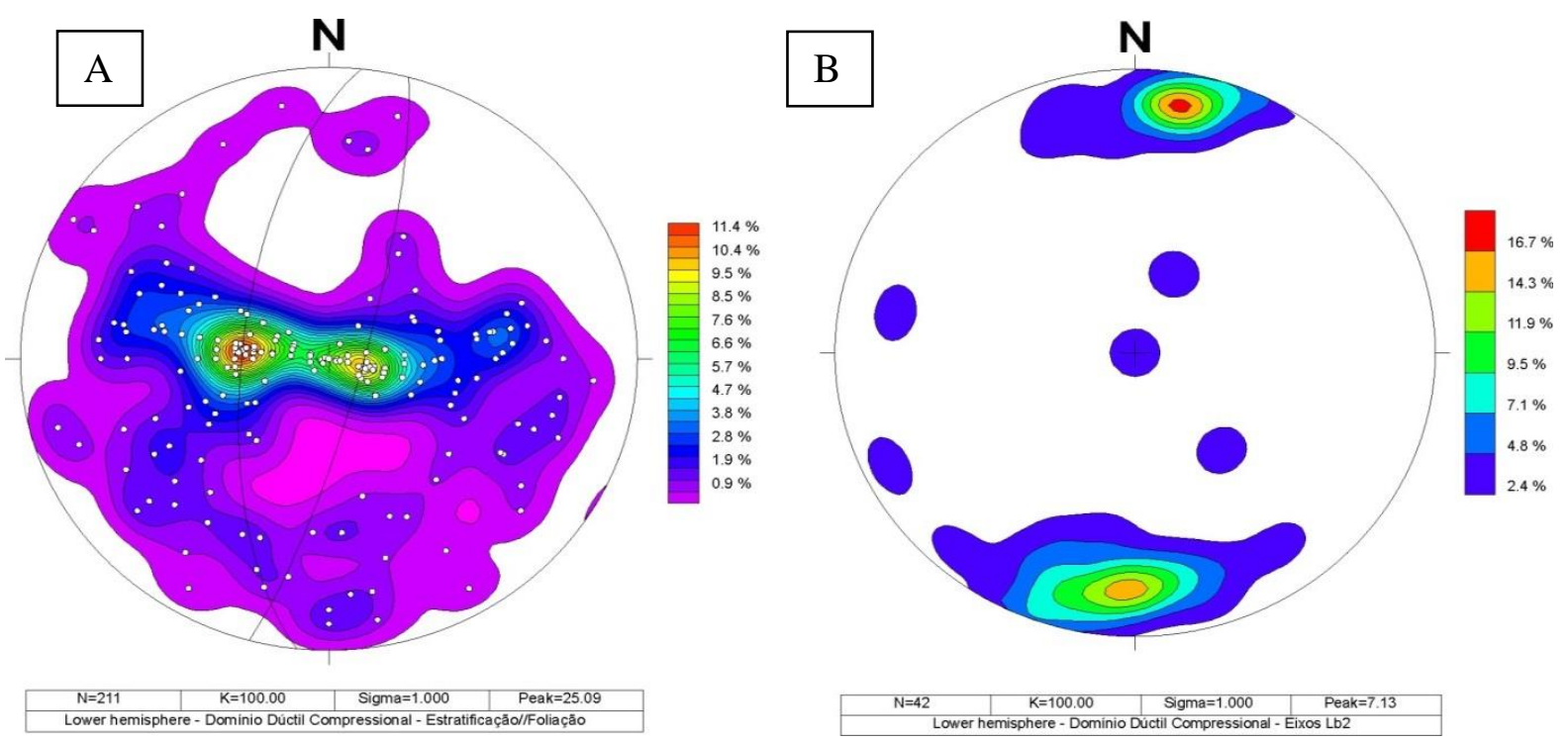

Figura 4.8) A- Estereograma das superfícies de xistosidade/estratificação (Sn0//Sn1- dobrada (Sn2) , subparalelos a plano axial de dobras geradas em domínio dúctil compressional, Grupos Araí, Serra da Mesa, Paranoá, Seqüência Metavulcanossedimentar de Palmeirópolis, Fm Monte do Carmo, (211 medidas). Intersecções de planos projetam os eixos $\mathrm{Lb}_{2}$ teóricos relacionados a este domínio B- Lineação Lb - Eixo de dobras -. (42 medidas); Medidas em DIP.


Figura 4.9) A- Aspecto regional de limbo de flanco de dobras no Grupo Serra da Mesa (serra homônima) com mergulhos acentuados para W/NW; B e C- aspecto de dobras apertadas (em planta) e dobras parasíticas (em perfil) em afloramentos de biotita xistos do Grupo Serra da Mesa. 
A idade do domínio compressional é provavelmente neoproterozoica e pode relacionar-se, (à exceção do Fm. Monte do Carmo) ao acoplamento do Arco Insular (Arco Magmático de Goiás), com o Maciço de Goiás e o Bloco Cavalcante-Natividade Cavalcante, em torno de 800 a 780 Ma. Zonas de falhas inversas, em níveis crustais rasos formam faixas cataclásticas, principalmente no contato emtre o Maciço de Goiás e o Bloco Cavalcante- Natividade, estas zonas são sobrepostas por metamorfismo de grau moderado a alto com recristalização parcial ao longo do contato dos blocos.

\subsection{3 - Domínio Dúctil Compressional -Transpressional Oeste}

Este domínio está registrado no extremo noroeste e impresso em todas as rochas do Orógeno Araguaia, no embasamento, o Complexo Rio dos Mangues, no Grupo Baixo Araguaia e na Suíte Aliança, atingindo a fácies metamórfica de anfibolito alto até xisto verde, corresponde a estrutura regional do Sistema Compressional Xambioá-Gurupi.

Caracteriza-se por uma deformação tangencial, de baixo ângulo que são formadoras de superfícies de cavalgamento, dobras assimétricas recumbentes e thrusts, Estas superfícies são zonas de cisalhamento dúcteis, resultado de uma tectônica compressiva, (figura 4.10). Pode-se observar neste domínio uma evolução no sentido da deformação de um sistema compressional para um sistema transpressional. Esta mudança é marcada na continua rotação dos eixos de estiramento Lx e na assimetria das dobras. Formam planos de cisalhamento de baixo ângulo analisadas como superfícies $\mathrm{S}_{2}$, materializados por foliações miloníticas e xistosidade de direção média N/S (N02 $\left.{ }^{0} \mathrm{~W} 29^{0} \mathrm{NE}\right)$.

Em relação ao domínio anterior este é considerado uma etapa deformacional tardia e registrada principalmente nas rochas da Orógeno Araguaia. O estereograma (Medidas em DIP) mostra uma distribuição com máximo unimodal ou guirlanda, conforme a figura 4.11A, com 195 medidas efetuadas. No estereograma, além de observar-se este máximo, pode-se notar a progressiva rotação destas superfícies, bem com a presença de flancos opostos e formadores de dobras assimétricas.

O estiramento mineral observado, principalmente nos metatonalitos e metagranodioritos da Suíte Aliança, reforça a análise de uma continua rotação do eixo de estiramento máximo de posição originalmente $\mathrm{N} 71^{0} \mathrm{~W} 32^{0} \mathrm{SE}$ para $\mathrm{N} 50^{\circ} \mathrm{E} 24^{0} \mathrm{NE}$, (figura 4.10). Isto caracteriza uma movimentação de massa inicial de SE para NW, progressivamente rotada e com deslocamento de massas de E/NE para W/SW. 


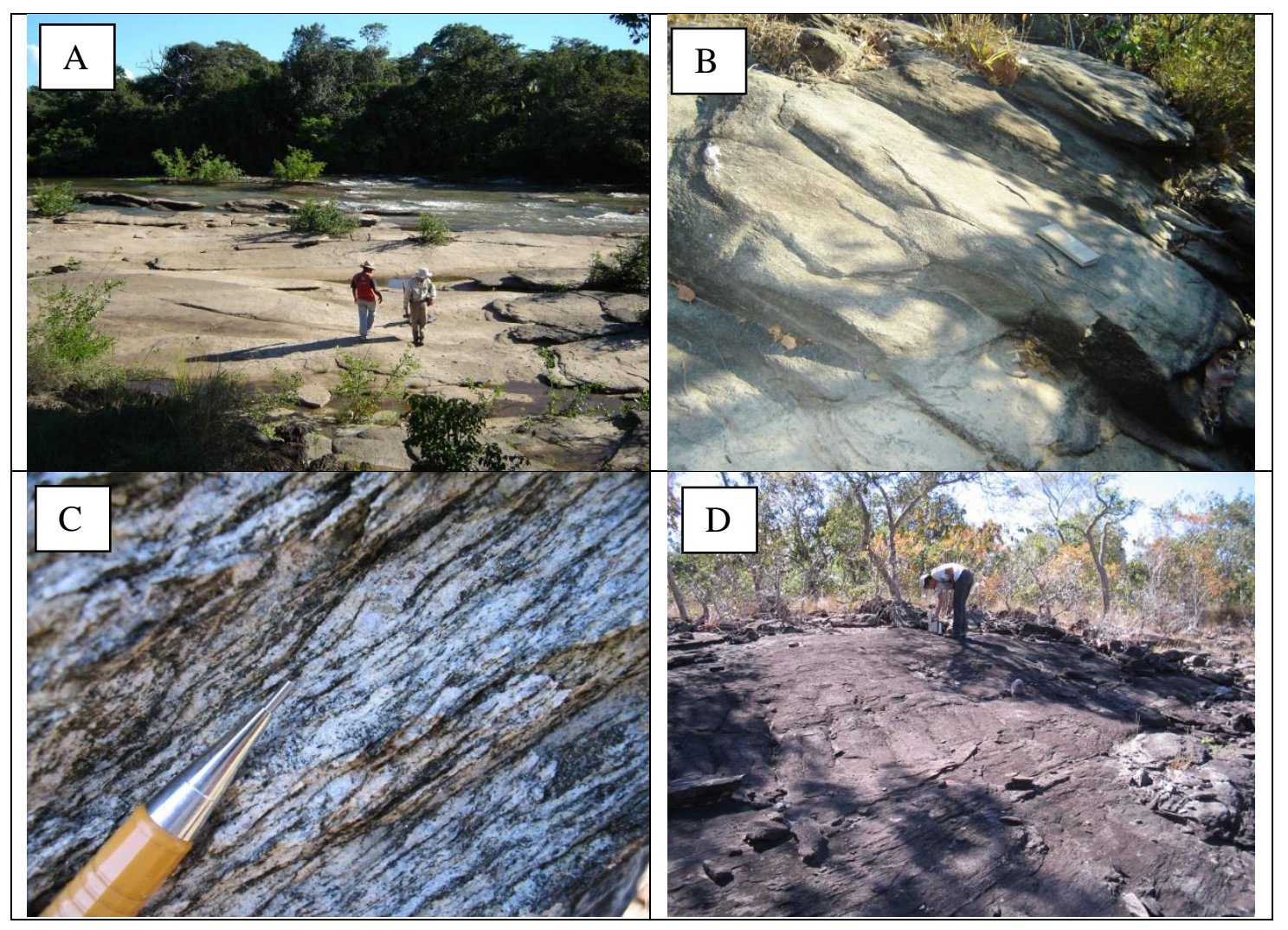

Figura 4.10- Domínio Compressional - Transpressional A) Aspecto geral da foliação de baixo ângulo observada no afloramento LL105 em córrego afluente do o rio Pau Seco no extremo oeste da folha, Suíte Aliança, B) Detalhe de foliação de baixo ângulo no embasamento da Orógeno Araguaia - Complexo Rio dos mangues envolvido em deformação Neoproterozóica; C e D) LL086 -Suíte Aliança , Granito Córrego das lages , corpos estratóides intrusivos, marcando a deformação de baixo ângulo, e detalhe da foliação com lx up dip marcando movimentação de massas para W/SW; LL098 zona de contacto em zona de falha de baixo ângulo.

A assimetria de quartzo e rotação de cristais porfiroclásticos indicam cinemática preponderante dextral e up dip e deformação sob cisalhamento simples demonstrando mais uma vez a passagem gradual de um sistema compressional para uma transpressão oblíqua.

As dobras neste domínio são de geometria assimétrica e tendência isoclinal, onde as dobras geradas na fase contracional anterior, são transpostas e ficam com padrão em bainha com paralelismo de seu plano axial com a foliação milonítica $S_{1} / / S_{2}$. O eixo de dobras encontradas apresenta-se na direção N/S, (figura 4.11c).

Padrões de fraturas, preenchidas por veios de quartzo e/ou intrusões aplíticas graníticas ocorrem associadas às direções de cisalhamento, ou concentrados em zonas de charneiras e/ou eixos de dobras assimétricas, conforme figura 4.11D. Estas concentrações de quartzo ao longo de eixos e charneiras formam importantes controles estruturais de mineralizações de quartzo hialino no Grupo Baixo Araguaia, Formação Pequizeiro dentro deste domínio estrutural. 
Os dois afloramentos-chave na Suíte Aliança merecem destaque são o HL033 e AF034, mesclados para análise na figura 4.12. Nas exposições com predomínio de rochas metatonalíticas e granodioríticas da Suíte Aliança observa-se todas as feições deformacionais descritas nos estereogramas, figura 4.11.

Estas exposições estão deformadas sob um regime de cisalhamento dúctil, em uma zona de direção $\mathrm{N} 20^{0}-40^{0} \mathrm{E}$, de alto strain, relacionada a faixas contracionais de baixo ângulo em rampas frontais de um fold-thrust belt. Este subsistema é parte da megazona de transcorrência dextral do Lineaento Transbrasiliano e as suas componentes no sistema Riedel. Os biotita-tonalitos e biotitagranodioritos e seus correspondentes metamórficos apresentam impressos estes os padrões e estilos deformacionais, as feições petrográficas, mineralógicas e dados de campo (fusões graníticas localizadas) indicam que a unidade foi submetida à fácies anfibolito alto.

Apesar do predomínio compressional-transpressional são também registradas nestes afloramentos feições transtracionais dúcteis-rúpteis, com a presença de efeitos de boudinagem e de estruturas do tipo pinch \& swell mais tardios. Cálculo do vetor tensional transpressivo $\sigma_{1}$ médio indica um posicionamento em torno de $\mathrm{N} 75^{0-} 80^{0} \mathrm{E}$. 

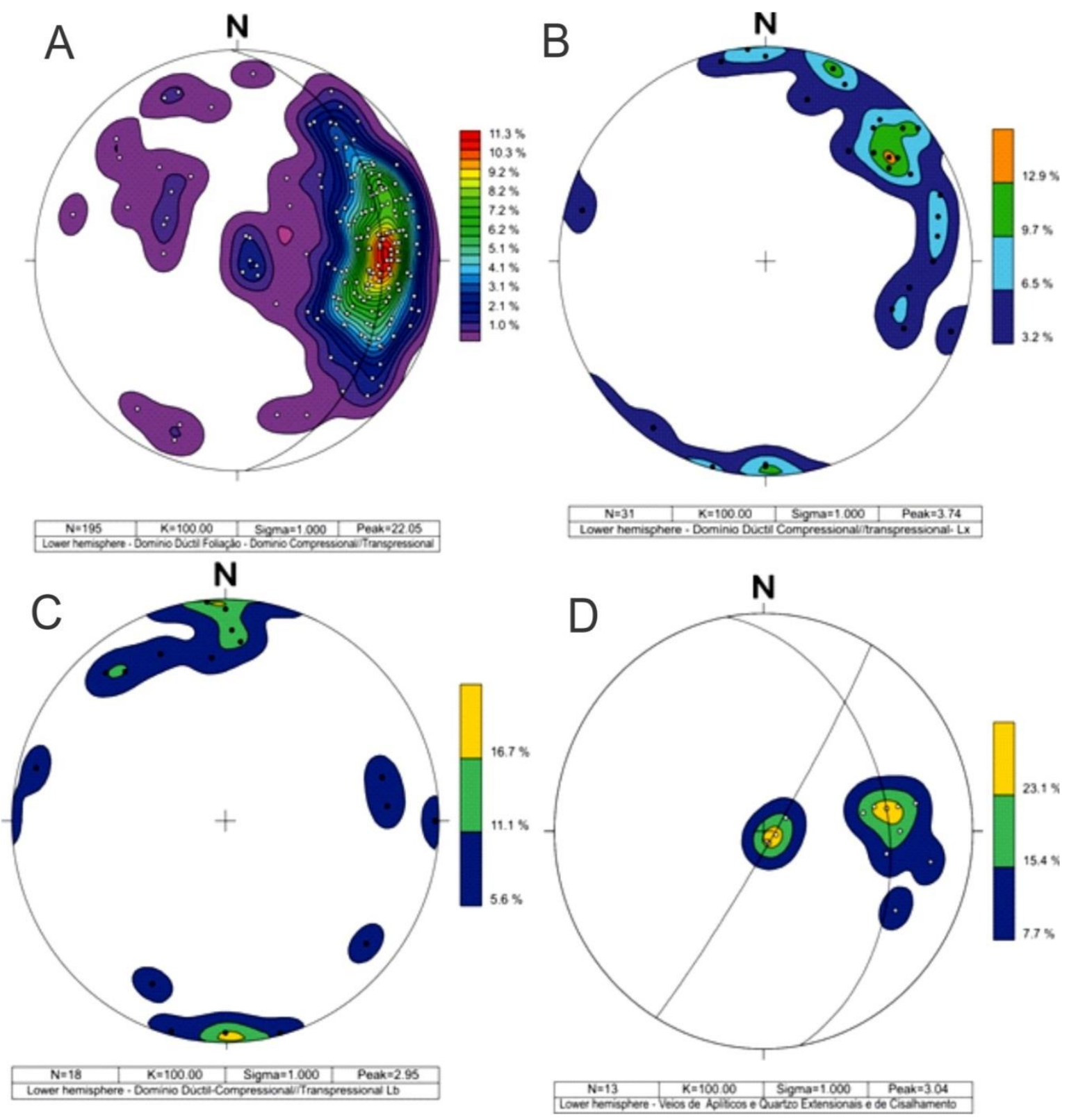

Figura 4.11) A - Estereograma das superfícies $S_{1} / / S_{2}$, foliação milonítica e xistosidades de baixo ângulo formadas em domínio dúctil compressional a transpressional, na Suíte Aliança e Grupo Baixo Araguaia (195 medidas) B - Lineação de estiramento mineral $\mathrm{L}_{\mathrm{x} 2}$ relacionado a fase 2 demonstrando o caráter preferencial oblíquo do deslocamento de massa (31 medidas); C - Estereograma dos superfícies dos eixos $\mathrm{Lb}_{2}$, de dobras assimétricas relacionadas a fase compressional, transpressional, com eixos subhorizontalizados e superfícies axiais compatíveis e foliação milonítica, (18 medidas). D Estereograma com as superfícies das fraturas de cisalhamento em alto ângulo e veios de quartzo extensionais subparalelos às superfícies plano-axial das dobras Lb2 (13 medidas). 


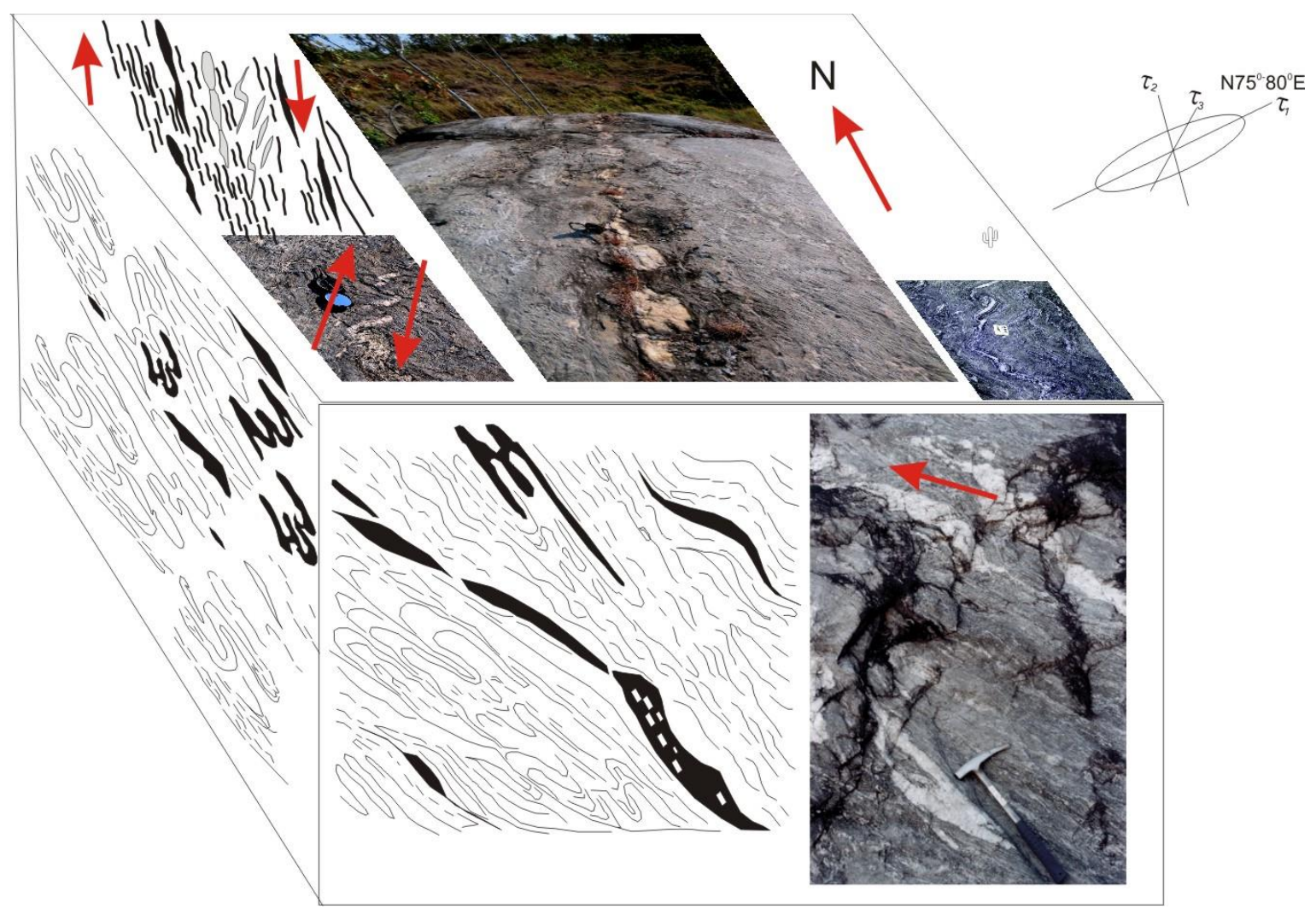

Figura 4.12)- Arranjo dos afloramentos HL033 e AF034, com fotos e sketchs de campo, mostrando em planos distintos os deslocamentos compostos relativos, transcorrentes dextrais na superfície topo; observam-se as dobras " $M$ " isoclinais assimétricas $S_{2}$, dobras em bainha $S_{1} / / s_{2}$, veios de quartzo sigmoidais e rompidos ao longo dos planos de zonas de cisalhamneto dúcteis de alto strain e Lx oblíquo de direção NE. Feições transtracionais como observado em boudins (foto topo) é superposição de fase posterior, (Frasca e Lima, 2010).

\subsection{4 - Domínio Dúctil Transcorrente Central}

É o domínio mais amplo em área de influência e marca de forma ímpar o Lineamento Transbrasiliano, também marca uma passagem progressiva e evolutiva dos dois últimos sistemas deformacionais descritos. Este domínio assinala um caráter transcorrente em seu inicio e transtracional em seu término e que afeta a grande parte das unidades geológicas, como também é responsável pelo posicionamento de inúmeros corpos graníticos.

Caracteriza-se por uma componente vetorial horizontal, sob sistema de fluxo de cisalhamento simples, não-coaxial, responsável por amplo sistema de zonas de cisalhamento dúcteis dextrais preponderantes e sinistrais N/S subordinadas, de geometria vertical a inclinada de direção NE e mergulhos altos e oscilantes para NW preferencialmente. 
Geram dobras de cisalhamento de $S_{1} / S_{3}$, foliação gerada na fase compressional $D_{1}$, redobrada na fase transcorrente $\mathrm{D}_{3}$, com plano axiais subverticais e subconcordantes as planos de cisalhamento e eixos verticais a subhorizontalizados, (figura 4.13 A e B).

A deformação é heterogênea dentro deste domínio com áreas de baixo e alto strain em zonas, com extrema variação textural/estrutural desde termos protomiloníticos a ultramiloníticos. O estereograma (figura 4.15A), com 170 medidas efetuadas mostra uma distribuição com máximo unimodal preferencial e na direção N26 $6^{0} \mathrm{E} 69^{0} \mathrm{NW}$, (medidas em DIP).

O estiramento mineral é observado principalmente na assimetria mineral, e feições de foliação do tipo S/C, (figura $4.14 \mathrm{~A}$ e B), com atitude entre $08^{0} 26^{0} \mathrm{NE}$ e $07^{0} 011^{0} \mathrm{NE}$, ora apresenta caimento para $08^{0} 212^{0} \mathrm{SW}$, caracterizando uma movimentação de massa principal de NE para SW, e progressivamente rotada para norte.



Figura 4.13A e B - Feição de dobras de cisalhamento assimétricas do domínio transcorrente, em planta, com eixos subverticalizados; Vista lateral das bandas de cisalhamento $\mathrm{N} 50^{\circ} \mathrm{E} 40^{\circ} \mathrm{NW}$, transpondo foliação anterior e planos de cisalhamento preenchidos por quartzo, (HL 131773306/8686998).

Neste domínio é nítida em diversos afloramentos e em várias unidades a rotação do vetor $\sigma_{1}$. Nas unidades de embasamento afetadas pela deformação neoproterozóica, observa-se porfiroblastos rotados para direita com fraturas " $\mathrm{T}$ " internas dispostas para $\mathrm{N} 72^{0} \mathrm{E}$, no afloramento HL065, 800571 18673305.

Nos afloramentos HL036 e HL037, na Suíte Matança (552 Ma), encontra-se uma série de indicadores cinemáticos que associados montam a posição de $\mathrm{T}$ e, por conseguinte o vetor $\sigma_{1 \text { : }}$ porfiroclastos em foliação $\mathrm{N} 20^{0}-35^{\circ} \mathrm{E}$ dextrais, veios aplítcos $\mathrm{N} 60^{\circ} \mathrm{W}$ e estruturas tipo horsetail colocando o vetor a este tempo em torno de $\mathrm{N} 70^{\circ}-80^{\circ} \mathrm{E}$. 


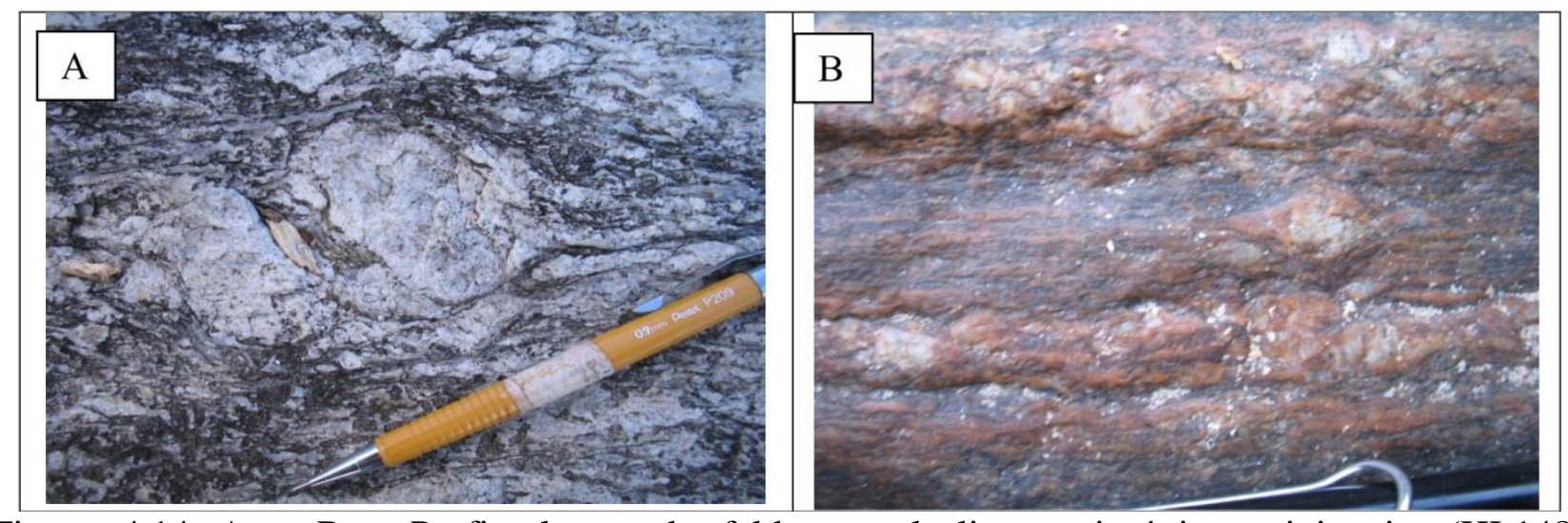

Figura 4.14 A e B - Porfiroclastos de feldspato alcalino assimétricos sinistrais, (HL148806926/8697618); Bandas de cisalhamento com porfiroclastos de feldspato assimétricas dextrais (HL141- 809841/8709302).

Intrusões pegmatíticas (556 Ma) apresentam fraturas internas em fenocristais tardios com indicação de um vetor $\sigma_{1}$ posicionado em $\mathrm{N} 60^{0} \mathrm{E}$. Este domínio, do ponto de vista metalogenético, marca uma importante etapa na deformação, pois é responsável pela geração de espaços estruturais para o posicionamento de inúmeros corpos graníticos crustais pós-colisionais a pós-orogênicos, sindeformação em ambiente transtracional, associados com intenso hidrotermalismo.

Padrões de fraturas extensionais tardias e preenchidas por veios de quartzo indicam atitude $\mathrm{N} 38^{0} \mathrm{E} 86^{\circ} \mathrm{SE}$, com o posicionamento de vetor $\sigma_{1}$ paralelo a esta direção no final do neoproterozóico/cambriano, (figura 4.15C).

A figura 4.16 é um esboço de campo, resultante da composição de afloramentos e exemplifica este domínio estrutural. Integram rochas do embasamento e intrusões neoproterozóicas em zona de transcorrência em zonas de baixo e alto strain.

Observa-se na sequência da figura 4.16 uma área de deformação progressiva na encaixante e na intrusão, desde discretas bandas miloníticas em granodioritos (A1), para uma foliação protomilonítica em granodioritos e granitos (A2), até intrusões graníticas grosseiras com pouca deformação (A3). Estruturas em mullions e outras feições são continuamente transpostas e paralelizadas lateralmente para áreas de maior strain. 


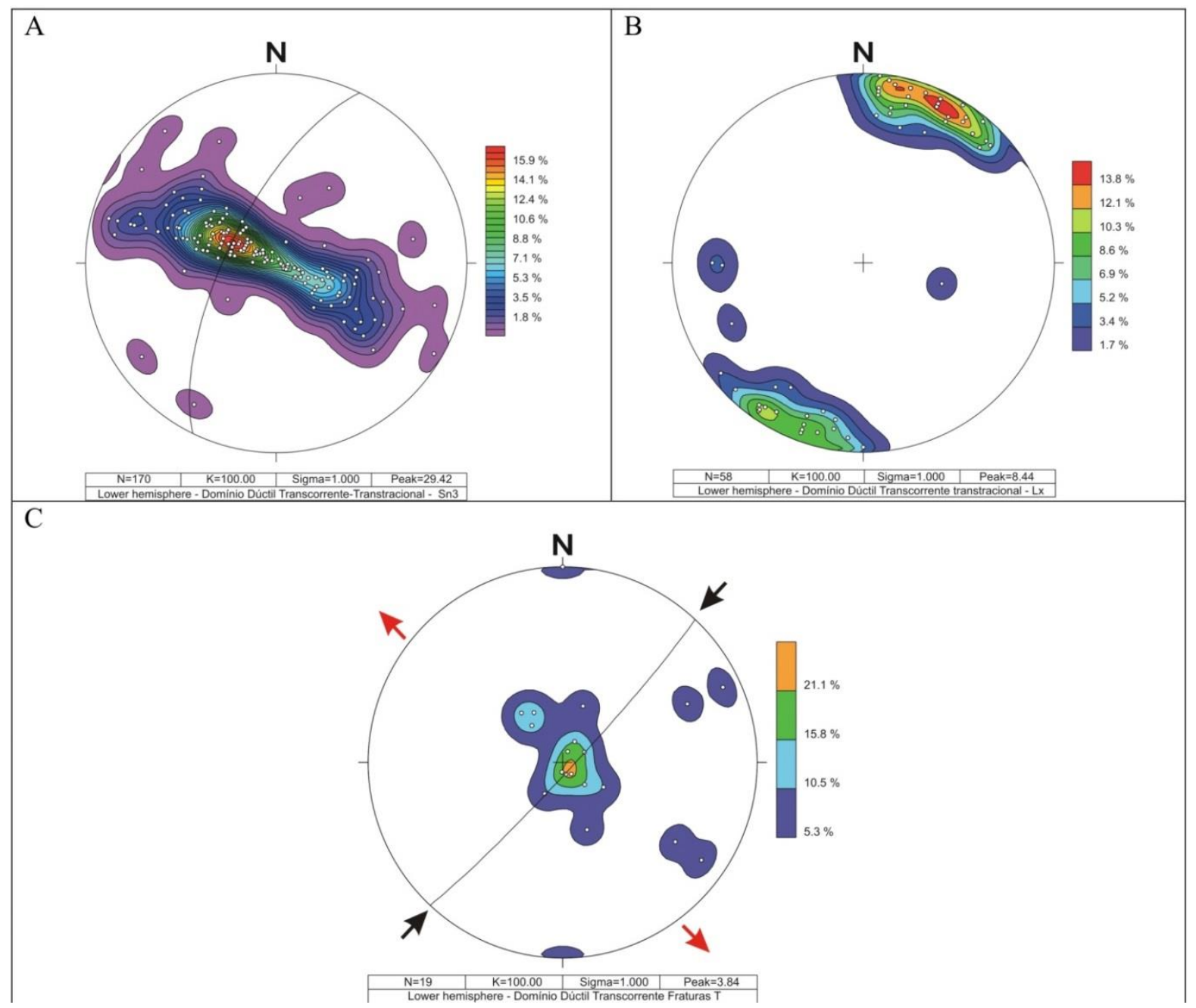

Figura 4.15 - A- Estereograma das superfícies $\mathrm{S}_{1} / / \mathrm{S}_{3}$, foliação milonítica de alto ângulo formada em domínio dúctil transcorrente a transtracional, (170 medidas); B - Lineação de estiramento mineral $\mathrm{L}_{\mathrm{x} 3}$ relacionada à fase 3 demonstrando o caráter subhorizontal (58 medidas); $\mathrm{C}$ - Posição dos planos das fraturas extensionais neste domínio (19 medidas), (Frasca e Lima, 2010).

Na sequencia de B1 a B4, observa-se a relação de composição tectônica em zona de alta deformação entre a encaixante e intrusão de hornblenda sienogranitos com injeções paralelas a foliação e bandamento pré-existente, deformados a posteriori em zonas transtracionadas. Em perfil observam-se os contatos retos da intrusão e de assimilação da encaixante de composição heterogênea formada por metadioritos, metatonalitos e metagranodioritos. Em planta apresentam feições sigmoidais de cinemática dextral.

A sequencia $\mathrm{C} 1$ e C2 indicam a encaixante fora da zona de alteração da intrusão, com bandas anfibolíticas e tonalíticas deformadas. D1 e D2 mostram as bordas da intrusão e encaixante com zona hidrotermal métrica e ocorrência de granadas centimétricas no contato da encaixante. 
A intrusão é forçada, caracterizada por material externo nas bordas e dentro da intrusão granítica, mas ajusta-se paralela a descontinuidades pré-existentes, preferencialmente ao longo de falhas transtracionais onde o espaço é gerado para seu posicionamento raso e formação de halos de alteração, mineralizando a encaixante com seus fluidos e calor.

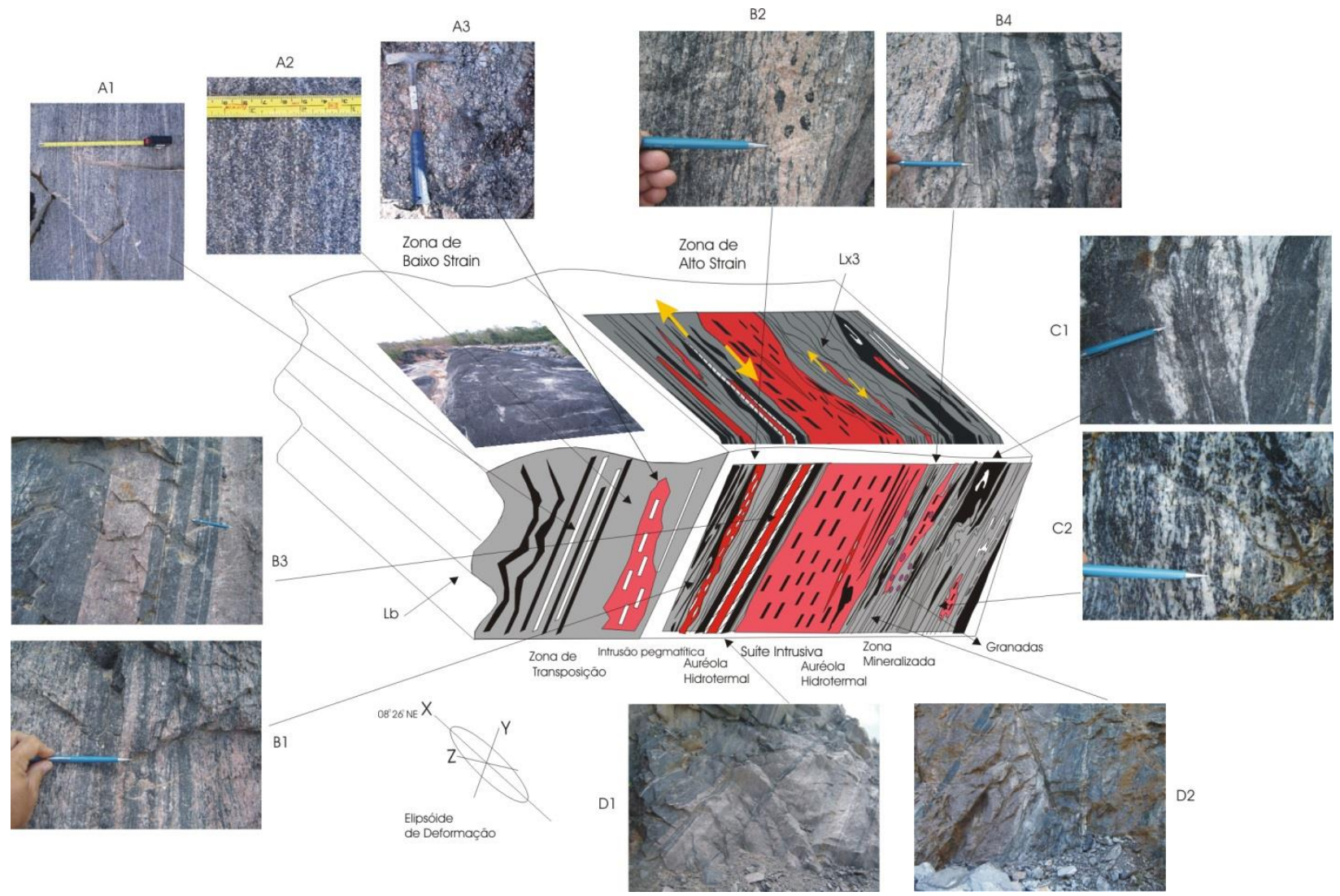

Figura 4.16 - Esboço composto dos afloramentos AF52 e LL262, integração com cerca de $150 \mathrm{~m}$ de extensão, dentro do domínio transcorrente transtracional, onde se observa lineação de estiramento com caimento subhorizontal para NE e demais feições descritas e comentadas no texto, (Frasca e Lima, 2010)..

\subsection{5 - Domínio Isótropo}

Neste domínio se encaixam os corpos anorogênicos da Suíte Ipueiras (2000 - 1873 Ma), relacionados ao Evento Transamazônico, e os granitos pós-orogênicos da Suíte Lajeado de idade neoproterozóica (530 Ma).

As feições deformacionais são do Brasiliano, de caráter rúptil, a rúptil dúctil, geradas por nucleação de fraturas com entrada externa de fluidos e formação de zonas miloníticas estreitas, mé- 
tricas e confinadas. As bordas de ambas as unidades apresentam padrões de fraturas e zonas cataclásticas de direção média NE.

\subsection{6 - Domínio Rúptil}

Trata-se da última fase de deformação que afetou indiscriminadamente todas as unidades litoestratigráficas. Constitui-se de um padrão de falhas e fraturas $\mathrm{N} 56^{0} \mathrm{~W} 86^{0} \mathrm{SW}$, (figura 4.17), abertas e de importância hidrogeológica. Sua cinemática não é bem conhecida, em certas áreas apresentam deslocamentos aparentes horizontais e em outras verticais. Presume-se que devam estar relacionados a esforços pós-cambrianos, pois afetam rochas desta idade, (formações Serra Grande e Pimenteiras).

Este sistema de fraturas parece controlar algumas seções retilíneas do rio Tocantins e demais córregos, transferindo a estas falhas e fraturas um conjunto ainda ativo e de reativação neogênica.

São também responsáveis pelos depósitos terciários e bacias balizadas por dois grandes lineamentos NW. Estes sedimentos se distribuem em uma grande área, com cerca de $2200 \mathrm{~km}^{2}$ no centro sul e que estão atualmente sendo retrabalhados por drenagens quaternárias.

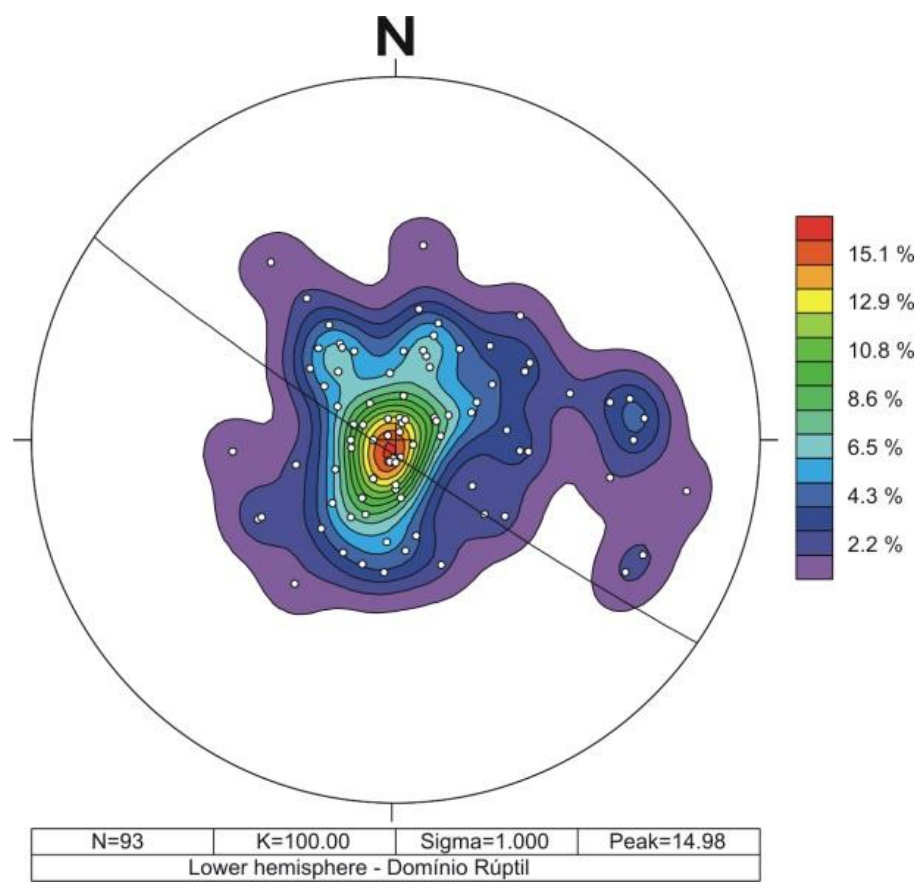

Figura 4.17 - Estereograma com as superfícies das falhas e fraturas abertas em alto ângulo e direção NW, (93 medidas). 
Os resultados indicam áreas com predominância de domínios estruturais com a justaposição de blocos distintos ao longo de descontunuidades estruturais e a superposição e interferência de um domínio sobre o outro. A configuração final é dada pelo Sistema do Lineamento Transbrasiliano que conecta todas as demais descontinuidades e blocos.

A geometria final do arcabouço transbrasiliano e a integração de seus domínios monta uma megaestrutura do tipo "рор up”, verticalizada em sua posição central e com mergulhos declinando de forma oposta para ambos os lados. Esta observação será tratada em maior detalhe no capitulo seguinte. 


\title{
Capítulo 5
}

\section{Arcos Acrescionários e Sistemas de Falhas Direcionais: O Caso do Arco Magmá- tico de Goiás, Neoproterozóico, Brasil-Central.}

\author{
Antonio A.S. Frasca ${ }^{\text {a, b, },}$,Elton L. Dantas ${ }^{a}$, Reinhardt A. Fuck ${ }^{a}$, Jaime E. Scandolara ${ }^{c}$ \\ ${ }^{a}$ Instituto de Geociências, Universidade de Brasília, CEP 70910-900 Brasília, DF, Brazil \\ ${ }^{\mathrm{b}}$ Geological Survey of Brazil (CPRM), Setor Marista, 148, CEP 74170-110 Goiânia, GO, Brazil \\ ${ }^{c}$ Geological Survey of Brazil (CPRM), SGAN 603, 1º Andar, CEP 70830-100 Brasília, DF, Brazil
}

\section{Resumo}

Os Orógenos Brasília e Araguaia desenvolveram-se na amálgama do W-Gondwana no neoproterozóico, consequência de consumo de placa oceânico, geração de arcos acrescionários insulares, margens continentais ativas e colisão dos crátons Amazônico e São Francisco-Congo. O Arco Magmático de Goiás (AMG) parte do Orógeno Brasília, encontrase na porção setentrional em contato com o Orógeno Araguaia, através do Lineamento Transbrasiliano (LTB). Dados litoquímicos e isotópicos distinguem períodos de acresção magmática diferentes, individualizados em um embasamento e quatro estágios magmáticos neoproterozóicos, todos combinados tectonicamente no LTB. O embasamento exibe um núcleo e lascas entremeadas no complexo orogênico neoproterozóico. Determinações $U$-Pb indicam idades de $2142+11$ a 2083+18 Ma com intervalos de $T_{D M} 2980 \mathrm{Ma}, 1950 \mathrm{Ma}$ a $1500 \mathrm{Ma}$, com evolução de $\varepsilon_{N d}$ mistos, sugerindo derivação parte crustal e parte juvenil. O fragmento de arco de ilha, chamado de Mara Rosa corresponde a tonalitos $e$ granodioritos gnaisses calci-alcalinos, depletados em LILE e HFSE, com idades de cristalização U-Pb entre $848 \pm 4$ Ma a $810 \pm 4 \mathrm{Ma}, T_{D M}$ entre 1480 e $910 \mathrm{Ma}$ e $\varepsilon_{N d(T 840)}$ com valores de +1.56 a +5.14 , sugerindo fontes juvenis. Um arco continental mais jovem de idade 670-630 Ma, nomeado de Santa Terezinha de Goiás e um compartimento mais recente com idades $U$-Pb em zircão em torno de 590 a 540 Ma, intrudem e reciclam as unidades mais antigas. O estágio colisional arco-continente apresenta LILE moderados a elevados, HFSE baixos a moderados, enriquecimento em ETRL $e$ depleção em ETRP sem anomalia de Eu, possuem fontes mistas e heterogêneas, parte reciclagem crustal, parte juvenis com $T_{D M}$ desde 2610 a $960 \mathrm{Ma}$, em média em torno de $1.2 \mathrm{Ga}$ e $\varepsilon_{N d}$ de -25.44 a +6.13 . O Estágio colisional representa a maturidade química do arco. Possui valores elevados LILE e HFSE com anomalias positivas em Th, La, K e Zr e padrões depletados em $\mathrm{Ba}, \mathrm{Nb}, \mathrm{P}$ e Ti, padrões assimétricos e enriquecidos em ETRL, depletados em ETRP com anomalias negativas de Eu. Determinações $U$-Pb em zircão indicam idades de 594+2 Ma, 586+3 Ma e 540+5 Ma e zircão herdados do arco insular com idades $822 \pm 15 \mathrm{Ma}, 884 \pm 11 \mathrm{Ma}$ e $855 \mathrm{Ma}, \mathrm{T}_{D M}$ entre 2860 e $900 \mathrm{Ma}$ e $\varepsilon_{N d(T 580)}$ de -22.42 $a+2.84$, a grande maioria negativa indicando retrabalhamento de crosta. $O$ estágio de arco maduro apresenta padrões comuns no arco continental pós-colisional. Há um maior enriquecimento em HFSE e ETRL do que em LILE. As idades de cristalização são próximas a 545 Ma. Rochas básicas pós-orogênicas analisadas apresentam fontes crustais e juvenis e $T_{D M}$ entre 1490 e $820 \mathrm{Ma}$, com $\varepsilon_{N d(T 530)}$.de -1.11 a +4.26 . O LTB Encerram em seu interior o embasamento e os dois arcos magmáticos que foram submetidos à intensa deformação. Faixas granulíticas em zonas de transpressão $e$ zonas de cisalhamento transcorrentes obliteram as suturas entre os blocos crustais, embaralhando e interrompendo unidades. O LTB apresenta uma arquitetura assimétrica e de vergência dupla, semelhante a uma mega "pop up". Os orógenos Brasília e Araguaia, posicionados dentro do LTB formam um complexo orogênico que compreende blocos do embasamento, acresções juvenis e margens continentais com duração 350 Ma, incluindo 100 Ma para geração do arco intraoceânico e 120 Ma para o período de acresção continental, com momentos de quiescência magmática entre eventos, desde a quebra de Rodínia à montagem de W-Gondwana.

Keywords: Brasília Orogen - Goiás Magmatic Arc - Strike Slip System - Transbrasilian Lineament - Orogenic Complex

\section{1 - Introdução}

O amálgama de massas continentais e a geração de supercontinentes marca a atuação de importante fenômeno na história evolutiva da Terra, indicando a eficiência dos processos de tectônica de placas, com a produção de crosta juvenil por fusão parcial e extração rápida no manto e o 
retrabalhamento de crosta continental por fusão parcial e/ou intenso metamorfismo de litosfera mais antiga (Condie, 2011). A sucessão de eventos culmina quando a quase totalidade das massas continentais são reunidas, sendo que a geração de arcos magmáticos desempenha importante papel no ciclo de formação de supercontinentes (McMenamim \& McMenamim, 1990; Moores, 1995; Dalziel, 2000; Hoffman, 1991; Nance et al., 2014).

Os continentes se formam pela aglutinação de terrenos alóctones, incluindo grandes e pequenos blocos continentais, arcos de ilhas e pequenas quantidades de crosta oceânica, e tornam-se maiores pelo crescimento de suas margens continentais. $\mathrm{O}$ crescimento marginal assume papel de suma importância, onde subducção de litosfera oceânica forma cinturões orogênicos caracterizados por deformação e magmatismo (Rogers e Santosh, 2002), envolvendo ciclos de Wilson completos de aberturas e fechamento, até a colisão continental. Em geral, uma vez amalgamados, os sistemas deixam suturas marcadas por grandes lineamentos crustais entre seus diversos e diferentes compartimentos tectônicos.

Na América do Sul, o Neoproterozóico tem seu registro marcado pela fragmentação do Supercontinente Rodínia (1.0 Ga) e a subsequente e sucessiva aglutinação de seus muitos fragmentos continentais para formação do Continente Gondwana há cerca de 0.5 Ga (Li et al., 2008; Fuck et al., 2008; Cordani et al., 2013). A colagem, que culmina na Orogenia Brasiliana, é caracterizada em seus primórdios pela simultaneidade ou diacronia de processos de montagem e quebras (fusão e fissão) da Plataforma Sul Americana ocorrentes em diferentes intervalos de tempo (1000-950 Ma, $750 \mathrm{Ma}, 550 \mathrm{Ma})$, (Brito Neves et al., 2014).

Na porção ocidental de Gondwana estava localizada a Província Orogênica Tocantins (Almeida et al., 1981), entre os crátons Amazônico e São Francisco-Congo. Nessa região formaram-se três grandes orógenos, as faixas Brasília, Paraguai e Araguaia. Um dos principais componentes deste quebra-cabeça tectônico é o Arco Magmático de Goiás (AMG) (Pimentel \& Fuck, 1992; Pimentel et al., 1997, 1998, 2000). Esta feição geotectônica se estende desde a região de Arenópolis e Bom Jardim de Goiás até Mara Rosa-Porangatu no estado de Goiás e o sul de Tocantins, ocupando a porção mais ocidental do Orógeno Brasília. O Arco Magmático de Goiás na área de estudo, compreende um segmento de $15.000 \mathrm{~km}^{2}$, dispondo-se em faixa de direção NE e adiciona cerca de 250 km de extensão por 60 a $80 \mathrm{~km}$ de largura ao compartimento do sistema de arcos magmáticos na porção setentrional.

O AMG desenvolveu-se por um longo período, como consequência do fechamento do Oceano Goianides-Pharusian cerca de 630 Ma atrás (Kröner \& Cordani, 2003; Caby, 1994; Piuzana et al., 2003; Valeriano et al., 2004, 2008), a princípio como arcos acrescionários insulares (Pimentel \& Fuck, 1992) e após, como margens continentais e orógenos colisionais com reciclagem crustal 
(Junges et al., 2002; Laux et al., 2005). A essência das unidades estratigráficas do AMG e de suas rochas sempre foi descrita como um conjunto vulcanossedimentar associado a ortognaisses de composição tonalítica e granodiorítica e anfibolitos subordinados (Pimentel e Fuck, 1992).

O AMG é limitado a oeste pelo Lineamento Transbrasiliano (LTB) (Schobbenhaus Filho et al., 1975). Quando do amálgama do West-Gondwana, esta feição estrutural, de direção principal NE-SW e direção secundária N-S, justapôs os orógenos Brasília e Araguaia ao longo de no mínimo $350 \mathrm{~km}$.

O comprimento do LTB é superior a $3000 \mathrm{~km}$ de extensão, sendo interpretado por alguns autores como uma sutura colisional (Cordani et al., 2003). Para outro autores é somente um sistema transcorrente relacionado com a tectônica de escape lateral dos antigos nucleos cratônicos circunvizinhos, os crátons Amazônico e São Francisco (Hasui et al., 2012).

Em sua porção setentrional, o AMG compreende diferentes períodos de acresção magmática, individualizados em um fragmento de arco de ilha juvenil de idade 900-800 Ma, chamado de Mara Rosa, um arco continental mais jovem com sequências vulcanossedimentares de idade 670630 Ma, nomeado de Santa Terezinha de Goiás (Fuck et al., 2002; Junges et al., 2002), e um compartimento mais recente, relacionado ao Complexo Porangatu-Novo Planalto, representado por gnaisses tonalíticos a graníticos com idades U-Pb em zircão em torno de 570 a 530 Ma (Dantas et al., 2007).

Esta complexidade abre espaço para uma série de questionamentos sobre a evolução do AMG e sua importância para a evolução da Província Tocantins (PT). Apesar dos de sistemas de amálgama de arcos na borda ocidental do W-Gondwana serem uma questão bem discutida, a continuidade destes arcos especificamente e seu prolongamento na região estudada, norte do estado de Goiás/sul de Tocantins, ainda está em aberto. A abordagem deste trabalho admite que haja várias interrelações geológicas estruturais entre o sistema de arcos e o Sistema de Transcorrência Transbrasiliano, ressaltando sua importância para os modelos de terrenos peri- e pré-Gondwânicos no Brasil central.

Outras questões que serão investigadas são: Como é o zoneamento magmático deste sistema acrescionário? Como o arco se comporta ao longo do LTB? É desmembrado ou contínuo? É um arco único com vários episódios de acresção ou trata-se de dois arcos em um mesmo sistema?

Na região do Tocantins foram realizados levantamentos de campo sistemáticos, estudos geoquímicos, estruturais e geocronológicos ao longo do LTB, onde diferentes períodos de acresção de fases magmáticas podem ser reconhecidas sob intensa deformação e encurtamento crustal. Este trabalho individualiza cada estágio tectonico dos arcos e embasamento que se interdigitam no segmento do LTB. 


\subsection{Geologia Regional e Tectônica}

Os orógenos Brasília e Araguaia são cinturões neoproterozóicos, integrantes da Província Tocantins, no Brasil Central, desenvolvidas durante o amálgama do W-Gondwana, como consequência da colisão entre os crátons Amazônico e São Francisco-Congo (fig. 5.1). As primeiras propostas de compartimentação geotectônica da Província Tocantins (Almeida, 1967, 1968; Hasui \& Almeida, 1970; Almeida et al., 1976, 1977, 1981), enfatizaram as faixas moveis formadas na borda oeste do Cráton do São Francisco e na borda leste/sudeste do Cráton Amazônico, bem como a ocorrência de terrenos gnáissicos e granulíticos, que constituiriam o embasamento antigo das sequências supracrustais da faixa (Almeida et al., 1976; Marini et al., 1984).

O embasamento do Orógeno Araguaia apresenta núcleos isolados arqueanos e remanescentes crustais paleoproterozóicos, intensamente envolvidos e retrabalhados pelos eventos deformacionais brasilianos (Moura e Gaudette, 1999; Moura e Souza, 1996). O metamorfismo dominante nos núcleos de embasamento é de fácies anfibolito a granulito.

No extremo nordeste da área as rochas do embasamento foram informalmente denominadas como Complexo Manuel Alves (Costa, 1985), o nome foi proposto para rochas na região homônima, entre Natividade e Santa Rosa do Tocantins, incluindo gnaisses miloníticos de composição tonalítica a granodiorítica, supracrustais e corpos de granitos pegmatóides de idade supostamente.

A oeste do LTB ocorre uma unidade de embasamento alóctone, o Complexo Rio dos Mangues (Costa, 1984), formado por conjunto de gnaisses e migmatitos tonalíticos e granodioríticos, gnaisses calcissilicáticos e intercalações anfibolíticas de idade Paleoproterozóica. Nesta mesma região, Gorayeb (1996) apresenta uma classificação litoestrutural e tectono metamórfica para as rochas do Complexo Porangatu, denominando-a de Faixa Granulitica de Porangatu que considera de idade paleoproterozóica.

As rochas metassedimentares neoproterozóicas da Faixa Araguaia exibem estruturação norte-sul, com mergulhos suaves para leste. São deformadas em regime dúctil e compressivo, causando imbricações das unidades basais, a leste, sobre as de topo a oeste. Rochas máficas e ultramáficas, incluindo peridotitos e dunitos serpentinizados, com cromita (Teixeira, 1996), associados à chert, jaspilito e pillow basaltos (Souza e Moreton, 1995; Kotschoubey et al., 2005; Paixão, 2008; Paixão et al., 2009), são identificadas como lascas de origem oceânica e interpretados como corpos ofiolíticos, tais como os complexos Quatipuru e Morro do Agostinho. 


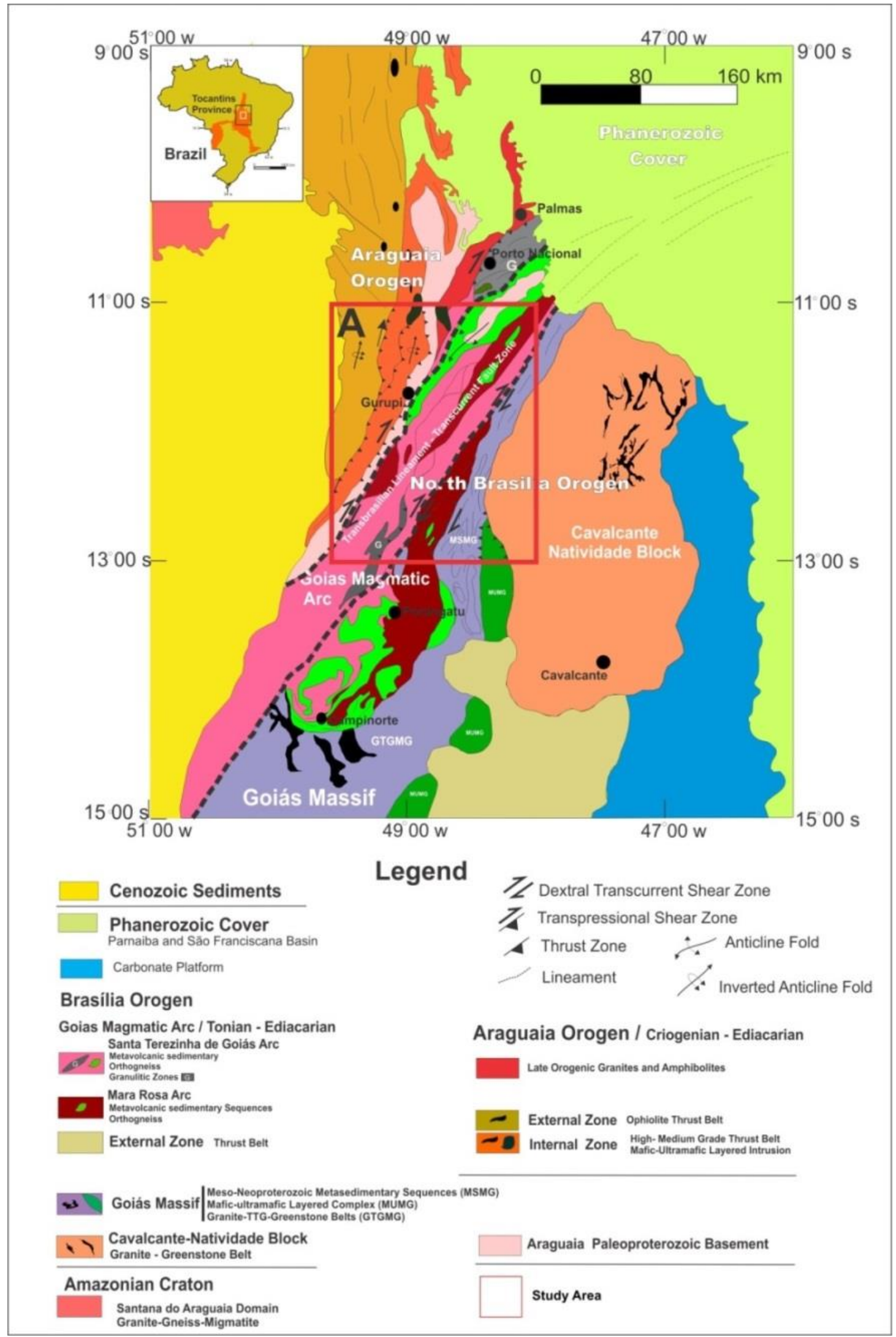

Fig. 5.1 - Contexto geológico regional da Província Tocantins. Orógenos Brasília e Araguaia. Retângulo central área de estudo. Composição regional adaptada de (Hasui et al., 1977; Fuck et al., 2014). Detalhes na área de estudo neste trabalho. 
Estes corpos sugerem processos de obducção de litosfera oceânica e são marcadores de zonas de sutura no amálgama do paleocontinente Gondwana Oeste. Dados químicos e isotópicos Sm$\mathrm{Nd}$ corroboram o caráter MORB da sequência ofiolítica, dado por valores positivos de $\varepsilon_{\mathrm{Nd}}+5 \mathrm{em}$ basaltos e diques gabróicos com $\varepsilon_{\mathrm{Nd}}+6,7$ que cortam os peridotitos, cuja idade obtida pelo método Sm-Nd é de 757士 49 Ma, que sugere um momento do estágio de oceanização do Orógeno Araguaia (Paixão et al., 2008).

Modelo considerando a anatomia de um orógeno colisional foi proposto por Fuck et al. (1992) para a Faixa Brasília. Esses autores identificaram na Faixa Brasília dois segmentos distintos (zonas externa e interna) que se diferenciam pela intensidade deformacional a que foram submetidos e por apresentarem polaridade metamórfica crescente em direção à zona interna da faixa. Várias outras propostas de compartimentação do cinturão foram elaboradas, com destaque para Costa e Angeiras (1970), Dardenne (1978, 2000), Marini (1981), Pimentel et al. (2000), Lacerda Filho et al. (1999), Delgado et al. in Bizzi et al. (2003), muitas das quais foram realizadas com base na intensidade dos processos deformacionais e metamórficos.

O embasamento do Orógeno Brasília na região estudada é um fragmento continental de idade paleoproterozóica dominante, composto por complexos granito-gnáissicos (Fuck et al., 2014). Na porção setentrional da Faixa Brasília, no estado de Tocantins, suítes plutônicas de arcos magmáticos calci-alcalinos se estendem por mais de 200 km e constituem uma extensão do Arco Magmático de Goiás (Pimentel et al. 1991; Pimentel e Fuck, 1992). O arco é balizado pelo Lineamento Transbrasiliano e amalgamado entre porções de embasamento das faixas Brasília e Araguaia.

O Arco Magmático de Goiás ocupa a porção ocidental da Orógeno Brasília. Representa o registro do consumo e fechamento do domínio oceânico Goianides-Pharusian (Kröner \& Cordani, 2003; Cordani et al., 2013) entre os crátons Amazônico e São Francisco-Congo. O Arco Magmático de Goiás é dividido em arco Arenópolis ao sul e arco Mara Rosa a norte (Pimentel \& Fuck, 1992; Pimentel et al., 1996, 1998, 2000) se estende desde a região de Arenópolis e Bom Jardim de Goiás, até Mara Rosa-Porangatu, ocupando a porção mais ocidental da Faixa Brasília. Diferentes episódios de acresção magmática foram reconhecidos no AMG.

Em sua porção setentrional, a fase pré-colisional compreende um arco de ilha juvenil de idade 900-800 Ma, chamado de Mara Rosa, caracterizado por mostrar rochas com afinidades tholeíitica e calci-alcalina com razões isotópicas ${ }^{87} \mathrm{Sr} /{ }^{86} \mathrm{Sr}$ iniciais baixas, valores $\varepsilon_{\mathrm{Nd}}$ positivos, com idade modelo $\mathrm{T}_{\mathrm{DM}}$ principalmente entre 1,1 e $0,8 \mathrm{Ga}$ e $\varepsilon_{\mathrm{Hf}}$ values $(+8$ to +12 ) (Pimentel \& Fuck, 1992; Laux et al., 2005, Matteini et al., 2010).

Um arco continental mais jovem, com sequências vulcanossedimentares de idade 670-630 Ma, nomeado de Santa Terezinha de Goiás (Fuck et al., 2002, 2006; Junges et al., 2002), estende-se 
tanto ao sul como a norte lateralmente ao Arco Insular de Mara Rosa. Constitui-se de rochas supracrustais e plutônicas de arco, incluindo tonalitos, granodioritos, gabros, dioritos e granitos muito deformados e gnaissificados. Idades U-Pb em zircão obtidas nessas rochas variam entre 640 e 620 Ma. Apresentam valores $\varepsilon_{\mathrm{Nd}}(\mathrm{T})$ entre $+2,8$ e $-15,1$, sendo a maioria das rochas com $\varepsilon_{\mathrm{Nd}}$ negativo, levando os autores a concluir pela provável formação em margem continental ativa no final da orogenia Brasiliana e pelo envolvimento de crosta continental mais antiga. $\mathrm{O}$ arco foi envolvido na colisão e tem seu principal evento magmático contemporâneo a ela. Dados indicam que o principal evento de subducção terminou entre o intervalo de 630-600 Ma, e que o principal pico metamórfico regional, ocorreu por volta de $630 \mathrm{Ma}$, conforme registrado em rochas granulíticas (Piuzana et al., 2003; Della Giustina et al., 2009).

Dantas et al., (2007) reconheceram novo evento magmático acrescionário na região de Porangatu Novo Planalto, representado por gnaisses tonalíticos a graníticos com idades $\mathrm{U}-\mathrm{Pb}$ em zircão em torno de 570 a $530 \mathrm{Ma}$. A assinatura isotópica caracterizada por idades modelo $\mathrm{T}_{\mathrm{DM}}$ entre 2.5 e 1.2 Ga sugere forte participação de crosta continental antiga na geração destes magmas. Este novo evento seria relacionado a uma historia pós-colisional do orógeno.

A complexidade do sistema AMG foi explorada por Chiarini (2007), em interpretações aerogeofísicas de alta resolução, que permitiram sugerir arquitetura crustal caracterizada por um arranjo de blocos litosféricos, com características isotópicas e geocronológicas distintas, limitados por expressivas zonas de cisalhamento. Foi identificada uma zonação dos diferentes episódios de acresção magmática no AMG, com diferentes domínios de susceptibilidade magnética para os eventos de 900 Ma (intra-oceânico) e 660 Ma (continental), respectivamente.

O Lineamento Transbrasiliano foi idealizado e denominado com Estrutura em Quilha Brasil Central (Hasui et al., 1994) de geometria encurvada e responsável pela colisão e justaposição de blocos crustais, associados a subducção, convergência obliqua sinistral e frontal. Chiarini, (2007) considera uma "cicatriz" de uma zona de sutura colisional entre o AMG e terrenos adjacentes. A feição é detectada em estudos de refração sísmica (Soares et al., 2006) e como grande anomalia positiva Bouguer e anomalia magnética profunda (Assumpção et al., 2004; Feng et al., 2007). Dantas et. al., (2013) interpreta o LTB como uma falha de transferência, formada após um processo de colisão obliqua, com a acresção de um sistema de arcos magmáticos neoproterozóicos à antigos fragmentos crustais paleoproterozóicos e a colagem de terrenos tectono-estratigráficos ao longo de movimentos direcionais, causando intenso retrabalhamento de margens de crátons e processos tardios de escape lateral.

A interpretação atual está baseada em dados geofísicos que sugerem uma densa litosfera mantélica subjacente ao arco magmático, onde a crosta tem apenas 36-38 km de espessura. Para 
leste, a espessura da crosta aumenta até $43 \mathrm{~km}$ abaixo da zona externa do Orógeno Brasília e parte do Cráton do São Francisco. A oeste, sob o gradiente da anomalia gravimétrica, dados de função do receptor mostram que a crosta pode atingir $53 \mathrm{~km}$ de espessura (Trindade et al., 2014). A estrutura é considerada o resultado da duplicação da parte inferior da paleoplaca Amazônica durante o final da subducção neoproterozóica abaixo do Arco Magmático de Goiás (Ventura et al., 2011).

Dados aeromagnetométricos realçam a arquitetura tectônica regional da Província Tocantins e a relação entre o AMG e a interconexão entre os orógenos Brasília e Araguaia. A feição estrutural mais evidente é a direção principal NE-SW e direção secundária N-S geradas durante o amálgama do West-Gondwana que justapôs os orógenos Brasília e Araguaia (Schobbenhaus Filho et al., 1975; Fuck et al., 2002, 2013). O LTB marca a individualização de distintos blocos litosféricos com história evolutiva distinta, limitados por grandes zonas de cisalhamento e falhas, cuja configuração atual é relacionada ao final da Orogenia Brasiliana e início do Cambriano.

O limite do Orógeno Araguaia é dado pelo Sistema Compressional Xambioá-Alvorada (Trouw et al., 1976); Herz et al., 1989). O sistema compreende uma zona de cavalgamentos e alinhamento de rochas ultrabásicas e básicas com mais de $900 \mathrm{~km}$ de extensão e vergência ao Cráton Amazônico. Almeida (1974) já havia delimitado esta zona como uma sutura ou falha convexa e a designou de Sutura Marginal Tocantins-Araguaia. A passagem do sistema tangencial para o regime transcorrente é progressiva e cada vez mais efetiva no limite entre as orógenos Brasília e Araguaia, próximo ao Lineamento Transbrasiliano.

O Sistema do Lineamento Maranhão-Paranã (Barbosa et al., 1969; Fonseca et al., 1995) é uma descontinuidade geológica, cujo traçado pode ser observado por mais de $300 \mathrm{Km}$, separando as rochas do AMG do embasamento paleoproterozóico de Cavalvante-Natividade. A Falha do Rio dos Bois é uma descontinuidade que separa o AMG do Maciço de Goiás, um terreno exótico da Faixa Brasília (Pimentel et al., 2003). A descontinuidade é marcada por uma falha inversa progredindo para norte para uma zona transpressionada oblíqua, onde se integra e se amolda ao Sistema Transbrasiliano.

Esses sistemas se interrelacionam e compõem características de deformação progressiva ocorrendo a sobreposição com padrões de interferência bem marcados e observados nas imagens aeromagnetométricas (fig. 5.2). A estes sistemas se associam outros, oblíquos/transcorrentes de menor expressão, mas de grande importância, na medida em que acomodam grande parte da deformação regional.

As relações registradas expressam uma íntima relação entre o AMG e o LTB. Dados geofísicos e geológico-estruturais apontam para cinemática oblíqua a paralela à direção das estruturas do arco e de suas zonas de suturas. Esta tipologia de grandes deslocamentos direcionais associados a 
zonas de subducção oblíqua parecem ser características de alguns orógenos, onde são capazes de ajustar compartimentos crustais distintos, (Vauchez e Nicolas, 1991). Assim, todos os sistemas de falhas mencionados desempenharam papel relevante durante o processo acrescionário do AMG. Movimentos verticais ocorreram expondo importantes áreas granulíticas. Movimentos frontais e transpressivos relacionam-se ao Sistema do Lineamento Maranhão-Paranã e da Falha do Rio dos Bois, mas a maior peculiaridade do LTB é o deslocamento ao longo de sua direção que foi capaz separar e reposicionar unidades geológicas por grandes distâncias.
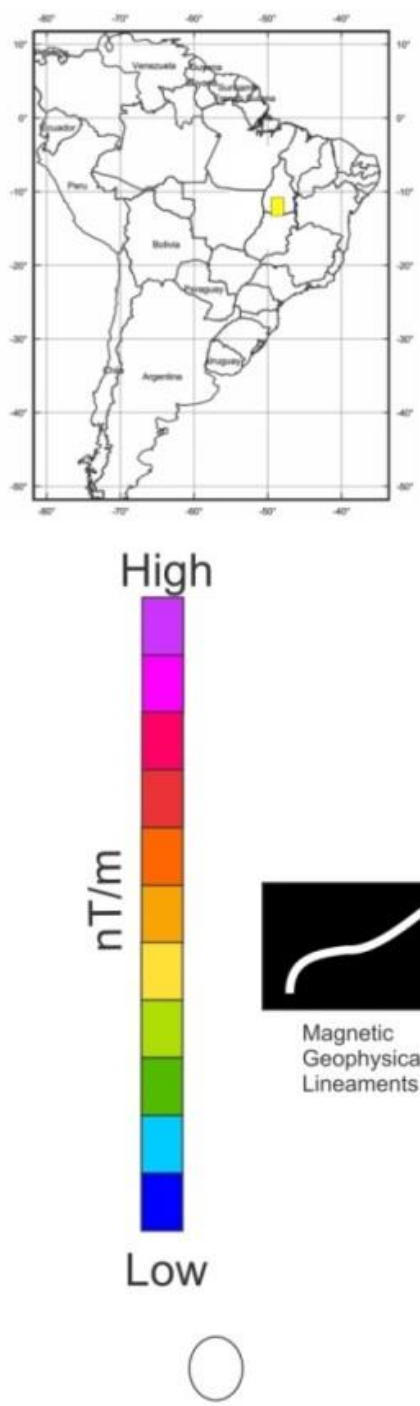

Towns and Villages

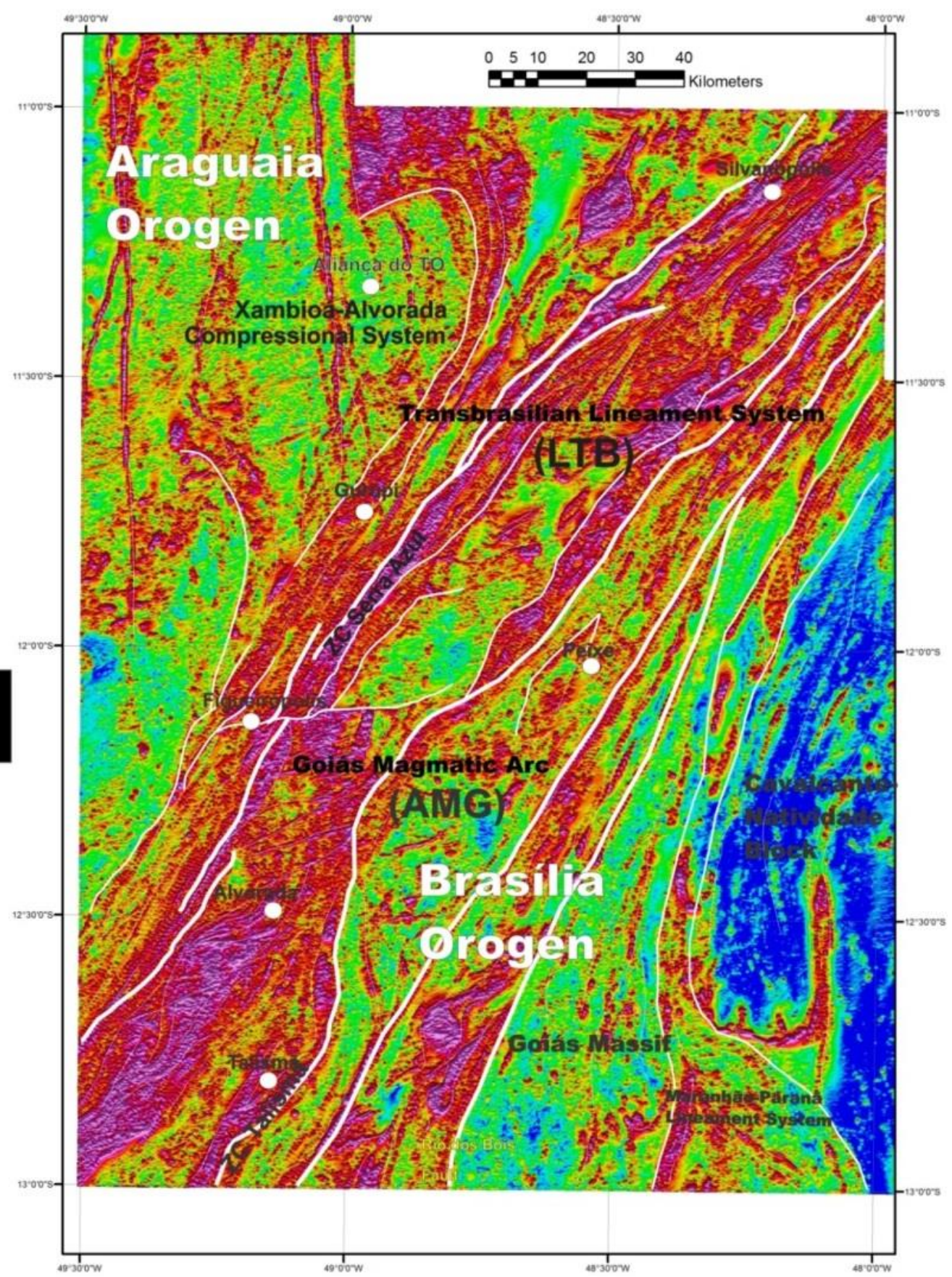

Fig. 5.2 - Imagem aeromagnetométrica da amplitude do sinal analítico da área em estudo mostrando profundas descontinuidades magnéticas que marcam zonas de falhas e possíveis suturas crustais. 


\subsection{Procedimentos Analíticos}

As análises químicas foram realizadas para elementos maiores $\mathrm{SiO}_{2}, \mathrm{TiO}_{2}, \mathrm{Al}_{2} \mathrm{O}_{3}, \mathrm{Fe}_{2} \mathrm{O}_{3}$, $\mathrm{MnO}, \mathrm{MgO}, \mathrm{CaO}, \mathrm{Na}_{2} \mathrm{O}, \mathrm{K}_{2} \mathrm{O}, \mathrm{P}_{2} \mathrm{O}_{5}, \mathrm{Cr}_{2} \mathrm{O}_{3}$, LOI, determinados por ICP-ES; os elementos traço Mo, $\mathrm{Cu}, \mathrm{Pb}, \mathrm{Zn}, \mathrm{As}, \mathrm{Cd}, \mathrm{Sb}, \mathrm{Bi}, \mathrm{Ag}, \mathrm{Au}, \mathrm{Hg}, \mathrm{Tl}, \mathrm{Se}, \mathrm{Sc}, \mathrm{Ba}, \mathrm{Be}, \mathrm{Co}, \mathrm{Cs}, \mathrm{Ga}, \mathrm{Hf}, \mathrm{Nb}, \mathrm{Rb}, \mathrm{Sn}, \mathrm{Sr}, \mathrm{Ta}, \mathrm{Th}$, $\mathrm{U}, \mathrm{V}, \mathrm{W}, \mathrm{Zr}, \mathrm{Y}$, e 14 ETR foram determinados por ICP-MS a partir de fusão de $\mathrm{LiBO}_{2}$ e realizados na ACME Labs, (tabelas 5.1 e 5.2). Foram analisadas 11 amostras de rochas do embasamento e 31 amostras de rochas do arco magmático, para distinção litogeoquímica das principais unidades ígneas, com ênfase nas rochas tonalíticas, granodioríticas e graníticas, com o objetivo de individualizar os conjuntos com afinidades e natureza geológica evolutiva em comum e compreender suas relações.

Do conjunto de 96 amostras tratado pelo método Sm-Nd, foram separadas 17 amostras para datação U-Pb em zircão. As análises foram realizadas no Laboratório de Geocronologia da Universidade de Brasília - UnB. Os concentrados de zircão foram extraídos a partir de 5 a $10 \mathrm{~kg}$ de amostras de rochas, inicialmente analisados em separador magnético Frantz. As frações minerais foram separadas sob lupa binocular para obter frações de tamanho semelhante, forma e cor. Após, os grãos foram dissolvidos em HF concentrado. As frações de zircão para análises convencionais U-Pb foram dissolvidas em concentrados de $\mathrm{HNO}_{3}$ e $\mathrm{HF}$ e foi utilizada uma mistura de ${ }^{205} \mathrm{~Pb}^{2}{ }^{25} \mathrm{U}$.

Seguiu-se extração química pela técnica padrão de troca iônica, utilizando microcolunas de Teflon, baseado em processos modificados de Krogh (1973). U e Pb foram impregnados em filamentos individuais de $\mathrm{Re}$ com $\mathrm{H}_{3} \mathrm{PO}_{4}$ e sílica gel e as análises isotópicas foram realizadas em espectrômetro multicoletor de massa Finnigan MAT-262 equipado com um contador de íons. Os resultados do procedimento para branco de $\mathrm{Pb}$, no momento da análise, foram melhores que $20 \mathrm{pg}$. Os programas PBDAT (Ludwig, 1993) e ISOPLOT-Ex (Ludwig, 2001) foram utilizados para a redução dos dados e o cálculo de idade, com erros para as razões isotópicas de $2 \sigma$.

Para as análises LA-ICPMS, os grãos de zircão foram montados em blocos de epóxi e polidos para obter superfície nivelada. As imagens de catodoluminescência foram obtidas por escaneamento em microscópio eletrônico e utilizadas para investigar as estruturas internas dos cristais. Antes das análises LA-ICPMS, os moldes foram limpos em $\mathrm{HNO}_{3}$ diluído (c. 2\%). Depois de completamente secas, as amostras foram montadas em uma célula de laser especialmente adaptada para seções polidas, e carregada em UP213 laser Nd: YAG $(\lambda=213 \mathrm{~nm})$ ligado a ICPMS Neptune. Utilizou-se hélio como gás transportador e misturou-se com Ar antes de entrar no ICP. Cada análise foi estudada e apenas os intervalos coerentes, com ausência de sinais de idade mista ou interceptos de 
fase secundária ou quebras foram escolhidos para o cálculo da idade final. Normalização para GJ zircão padrão (608.5 — 1,5 Ma; Jackson et al., 2004) e cálculos de idade foram realizados utilizando uma planilha em Excel desenvolvido internamente no laboratório, baseado em fórmulas ISOPLOT v.3 (Ludwig, 2003). ${ }^{204} \mathrm{Hg}$ e ${ }^{202} \mathrm{Hg}$ foram medidos para avaliar a interferência isobárica no ${ }^{204} \mathrm{~Pb}$. Correções para $\mathrm{Pb}$ comum foram realizadas nas análises apresentando razões ${ }^{206} \mathrm{~Pb} /{ }^{204} \mathrm{~Pb}$ inferiores a 1000, utilizando o modelo de idade de cristalização de Stacey e Kramers (1975). Os dados U-Pb foram obtidos no programa ISOPLOT v.3 (Ludwig, 2003). O anexo 1 apresenta os resultados.

Para as análises isotópicas de Sm-Nd, realizadas no Laboratório de Geocronologia da Universidade de Brasília, foi seguido o método descrito por Gioia e Pimentel (2000), no qual 50 mg de pó de rocha total foram misturados solução padrão com ${ }^{149} \mathrm{Sm}^{-150} \mathrm{Nd}$ e dissolvidos em cápsulas Savillex. A extração de Sm e Nd seguiu técnicas de permuta iônica convencionais, usando colunas de teflon contendo resina LN-Spec (ácido fosfórico HDEHP-diethylhexil suportado em pó PTFE). Amostras foram carregadas em filamentos de evaporação de Re e as medidas isotópicas foram realizadas em espectrômetro de massa multicoletor Finnigan MAT262 em modo estático. Incertezas

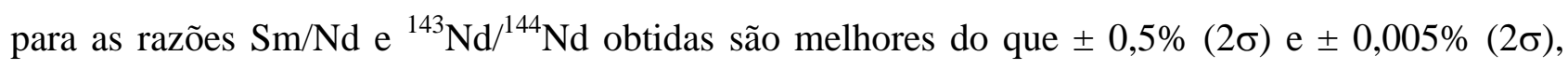
respectivamente, baseadas em repetidas análises dos padrões de rocha internacional BHVO-1 e BCR-1. As razões ${ }^{143} \mathrm{Nd} /{ }^{144} \mathrm{Nd}$ e foram normalizadas para ${ }^{146} \mathrm{Nd} /{ }^{144} \mathrm{Nd}$ de 0,7219 e a constante de decaimento utilizada foi $6,54 \times 10^{-12} \mathrm{a}^{-1}$. Os valores TDM foram calculados com base no modelo de DePaolo (1981).

\section{RESULTADOS}

\subsection{Geologia e Geocronologia}

Os orógenos Brasília e Araguaia estão balizados pelo Lineamento Transbrasiliano e suas ramificações estruturais, que posicionam lado a lado rochas de diferentes idades e afinidades geotectônicas. Os limites do LTB são dados por zonas de cisalhamento transcorrentes, que formam um corredor de 60 a $80 \mathrm{~km}$ de largura e se estende por mais de $240 \mathrm{~km}$ de comprimento na área foco deste trabalho, compreendendo área superior a $15000 \mathrm{~km}^{2}$ no estado do Tocantins. Neste corredor ocorre o embaralhamento tectônico que mescla lascas paleoproterozóicas do embasamento com diferentes terrenos neoproterozóicos. Neste segmento do LTB as rochas do AMG foram intensamente encurtadas e se encontram paralelizadas em faixas alongadas preferencialmente na direção $\mathrm{N} 30^{\circ} \mathrm{E}$. As rochas do arco magmático estão delimitadas por dois blocos independentes e distintos de embasamento, conforme fig.5.3 que apresenta um esboço geológico simplificado. 


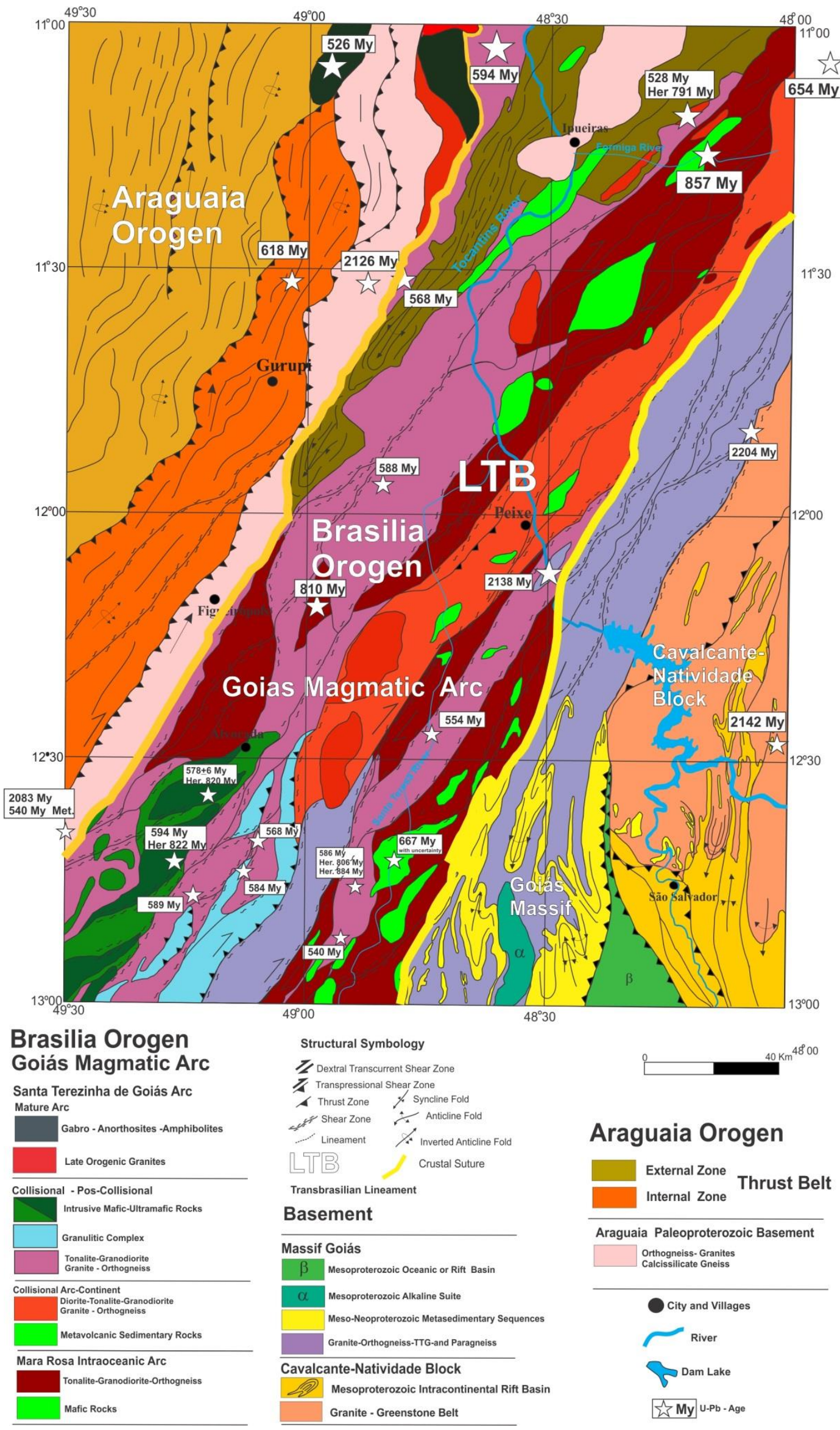


Fig. 5.3 - Esboço geológico local com ênfase aos principais segmentos geotectônicos.

As idades U-Pb registradas marcam eventos da amálgama do continente Gondwana. Apresentam simultaneidade aos ciclos de construção de supercontinentes e são coincidentes e diacrônicos com os períodos de fragmentação de Rodinia e as colisões de montagem de Gondwana Ocidental (Condie, 2012). O anexo I apresenta a tabela com as datações U-Pb utilizadas.

\subsection{1 - Embasamento}

O núcleo paleoproterozóico, denominado Bloco Cavalcante-Natividade, está exposto a leste (Fuck et al., 2014). Em termos litológicos, o bloco é constituído por associações de terrenos tipo TTG e greenstone belts, gnaisses orto e paraderivados, granitos peraluminosos sin- a pós-colisionais e rochas supracrustais gnaissificadas, incluindo metavulcânicas e metassedimentares meso- a neoproterozóicas. A idade do magmatismo na região de Cavalcante varia entre 2.3, 2.2 e 2.15 Ga e sugere geração de diferentes fragmentos de crosta continental juvenil e retrabalhada no Paleoproterozóico (Fuck et al., 2014). Determinação U-Pb em zircão de tonalitos e granodioritos gnaisses do Bloco Cavalcante-Natividade a leste do LTB indicam a idade de cristalização de 2142+11, (fig. 5.4A).

Entre o Bloco Cavalcante-Natividade e o AMG se posiciona um segmento crustal estreito e intensamente deformado, considerado como extensão do Maciço de Goiás. Constitui-se de diversas unidades diferentes em origem, natureza e idades. Ocorrem paragnaisses ricos em grafite intercalados a gnaisses tonalíticos e granodioríticos polideformados e não possuem uma definição estratigráfica formal. Datação U-Pb em zircão de um tonalito gnaisse (fig. 5.4B) indicou idade de cristalização de 2138+10 Ma em uma lasca do embasamento

Em discordância ocorrem formações metassedimentares do Grupo Serra da Mesa, de idade presumida meso-neoproterozoica e uma sequència metavulcanossedimentar supostamente do tipo oceânico, denominado Palmeirópolis. Estas unidades são intrudidas pelo Complexo Alcalino de Peixe e por corpos graníticos e pegmatitos ricos em Th e U. Este conjunto de unidades dispõem-se como um cinturão de dobras assimétricas sinclinais e anticlinais fechados.

O Complexo Rio dos Mangues representa o embasamento do Orógeno Araguaia expõem-se a oeste do LTB e o AMG. Datação U-Pb em zircão obteve idades de 2126 +77 Ma em gnaisses tonalíticos a nordeste de Gurupi (Frasca \& Lima, 2005). No extremo sudoeste da área o afloramento TA25, um granito do embasamento indicou idade U-Pb em zircão de 2083+18 Ma. 


\subsection{2 - Arcos Neoproterozóicos}

Modelos de acresção de arcos são difíceis de estabelecer, porque o registro é incompleto e os terrenos dos arcos são fragmentados durante o evento orogênico, a deformação e o metamorfismo subsequentes. No caso do Arco Magmático de Goiás em sua porção setentrional está complexidade e desmembramento refere-se diretamente ao sistema do LTB. Ponderando-se este fato a área em estudo preserva características das diferentes fases de acresção em um modelo geodinâmico de colisão de arco-arco e arco-continente. Visando distinguir os vários compartimentos utilizou-se química de rocha, geologia isotópica e geocronologia.

Os afloramentos com rocha sã na área são escassos e ocorrem principalmente no leito dos rios. Não obstante, foram identificados diferentes conjuntos de rochas, possibilitando organizar os eventos de magmatismo de acordo com características petrológicas que refletem a origem dos magmas e estágios geodinâmicos dos processos de acresção ocorridos durante a evolução do arco.

Estágio de arco intra-oceânico - Aqui denominado de Evento de Acresção Mara Rosa, área tipo onde foi inicialmente reconhecido (Pimentel \& Fuck, 1992). As rochas relacionadas a este evento organizam-se em faixas alongadas de direção NE-SW, caracterizadas por sua alta suscetibilidade magnética e a presença de rochas derivadas de magmas bastante primitivos. São reconhecidas duas faixas: uma no extremo nordeste, em Silvanópolis, onde é recoberta pelas rochas sedimentares da Bacia do Parnaíba, e ao longo do rio Formiga, estendendo-se para sul, e outra na porção meridional, a leste de Talismã e ao longo do rio Santa Teresa.

As rochas relacionadas a esta fase magmática é representada por gnaisses miloníticos de composição predominante tonalítica a gabro-diorítica e granodiorítica subordinada (fig. 5.5 -A a F). Grande quantidade de anfibolitos, hornblenda metagabro e metaquartzo-dioritos também são associados a este magmatismo. Intensa deformação sobreposta desenvolveu foliação milonítica nas zonas de cisalhamento transcorrentes e ao longo dos contatos com unidades adjacentes. Sua relação com as unidades félsicas intrusivas ainda é objeto de investigação.

São rochas bandadas e/ou foliadas, com textura média a grossa, textura inequigranular xenomórfica a hipidiomórfica, porfirítica a porfiroclástica. Rochas mais deformadas exibem agregados granoblásticos de feldspato e quartzo devido à recristalização parcial desses minerais e arranjo lepidoblástico de muscovita e biotita, formando a foliação e o bandamento. Há recristalização parcial dos grãos originais, formando agregados de sub-grãos granoblásticos, principalmente de feldspatos e quartzo. Menos frequentemente há formação de matriz grano-nematoblástica marcada pela orientação de hornblenda. 

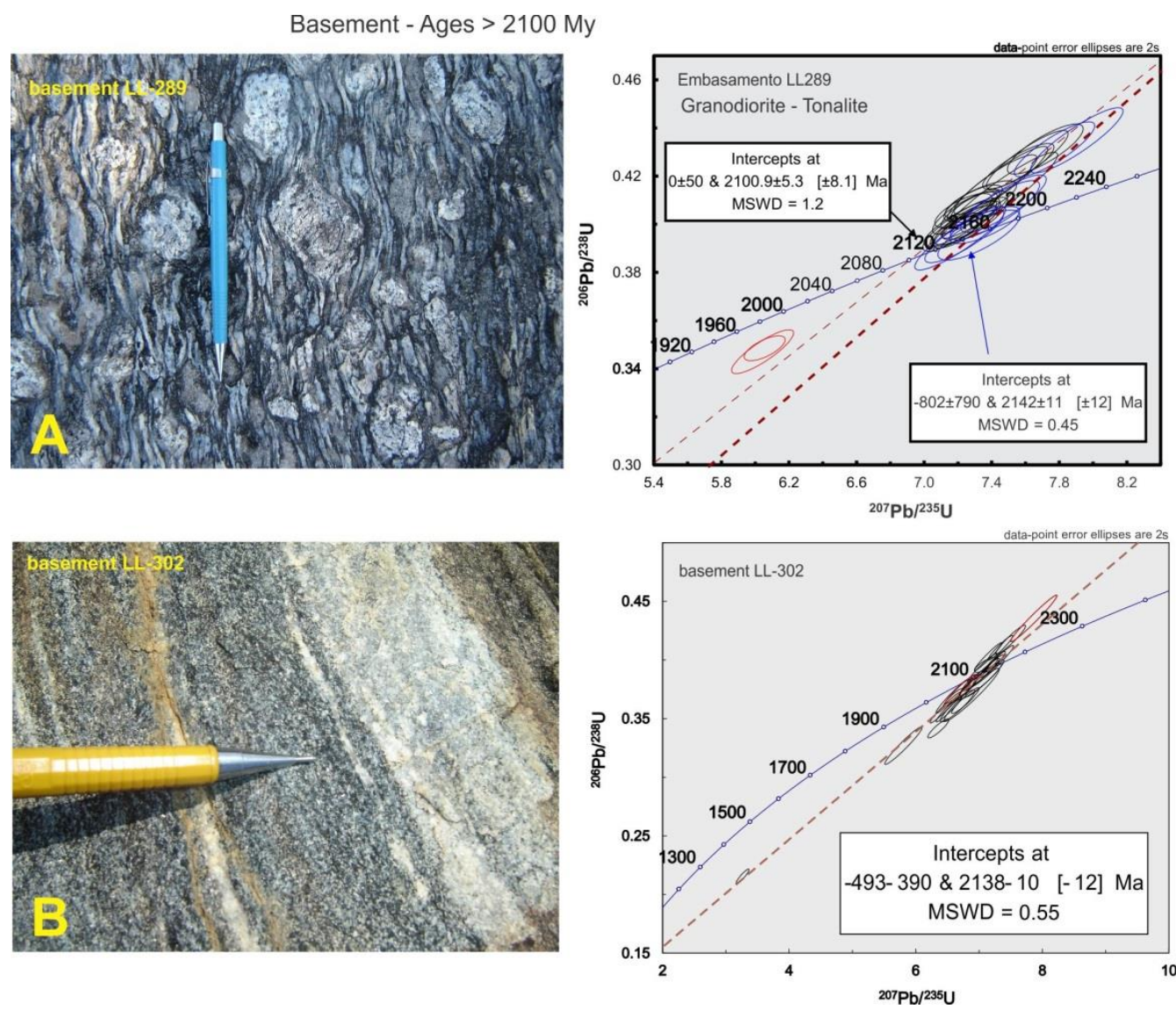

Fig. 5.4 - A) Augen gnaisses tonaliticos e B) tonalitos e granodioritos gnaisses do embasamento, intensamente deformados com as respectivas idades U-Pb em zircão admitidas como de cristalização.

Inclusos nos gnaisses tonalíticos e granodioríticos ocorrem corpos lentiformes e sigmoidais de rochas máficas e máfico-ultramáficas. São rochas de coloração preta a verde escuro, de granulação média a grossa, textura inequigranular, hipidiomórfica e de composição heterogênea. Apresentam-se também como autólitos, ora encaixados nos gnaisses tonalíticos ou como restitos e enclaves, que são ora maciços e homogêneos, ora anisótropos e foliados. Petrograficamente são gabronoritos, olivina gabronoritos, piroxenitos, gabros e dunitos serpentinizados, formados principalmente por plagioclásio, ortopiroxênio, clinopiroxênio, olivina, serpentina. Magnetita ocorre em percentagens de $2 \%$ a $5 \%$.

Datação U-Pb em zircão de granodiorito-tonalito augen-gnaisse, rico em magnetita da amostra (TA36B) indicam concórdia com idade de 848+4, (fig. 5.6 A). Idades mais jovens em torno de 810 4 Ma são também encontradas nas amostras. Os cristais são ígneos com morfologia elongada a euédrica, tipo peduncular a prismáticos, levemente rosados, (fig. 5.6B). 


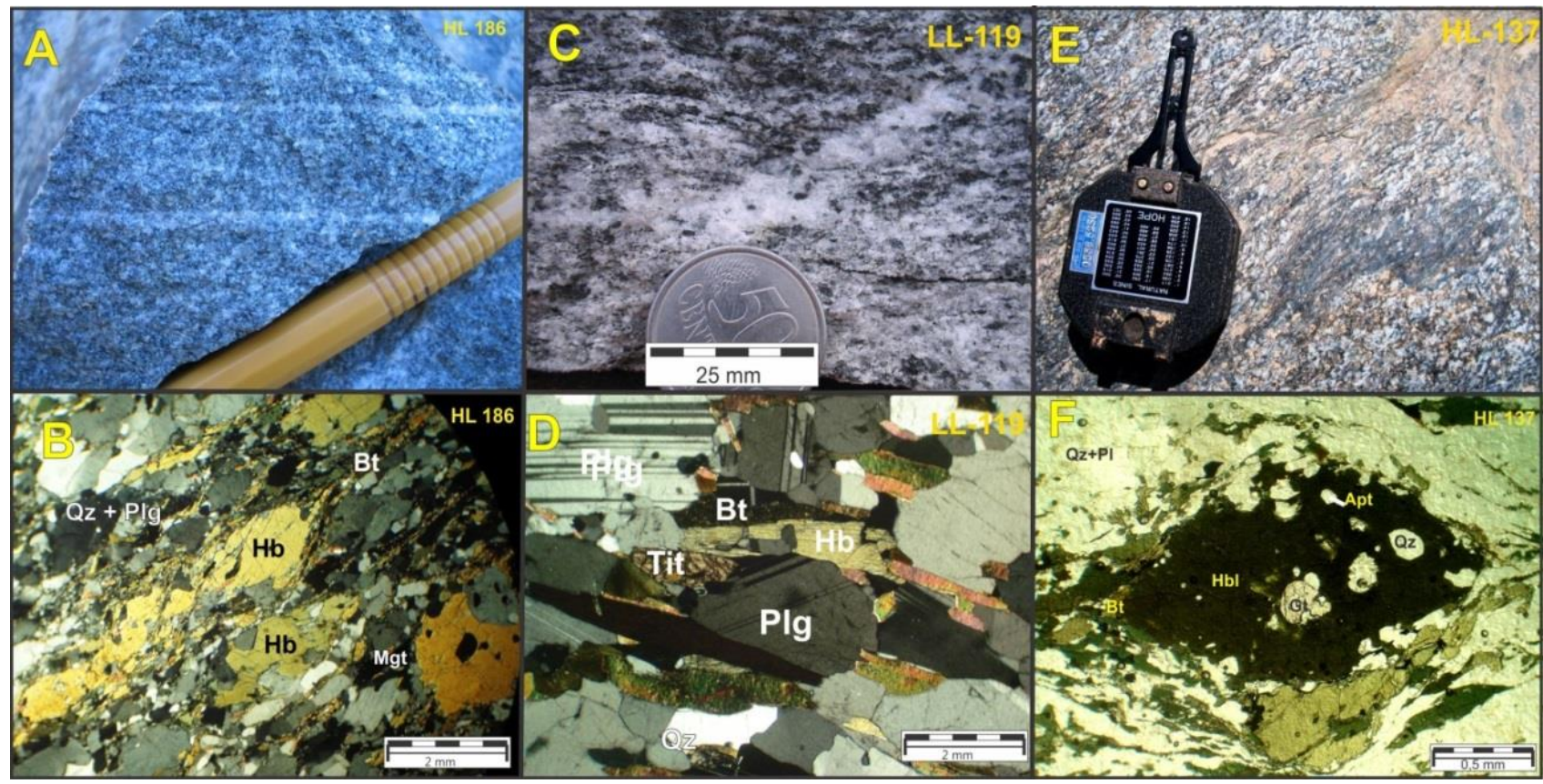

Fig. 5.5 - Rochas intermediárias a ácidas do estágio de arco intra-oceânico. A) Aspecto macro dos hornblenda tonalitos foliados; B) fotomicrografia exibindo deformação dúctil, estiramento mineral e cinemática dextral; C) e D) aspecto dos hornblenda biotita quartzo diorito/tonalito com marcando inicio de bandamento e recristalização de minerais; E) $e$ D) Granodiorito milonitico com aglomerados máficos deformados e fenocristais de hornblenda estirados com cinemática dextral.
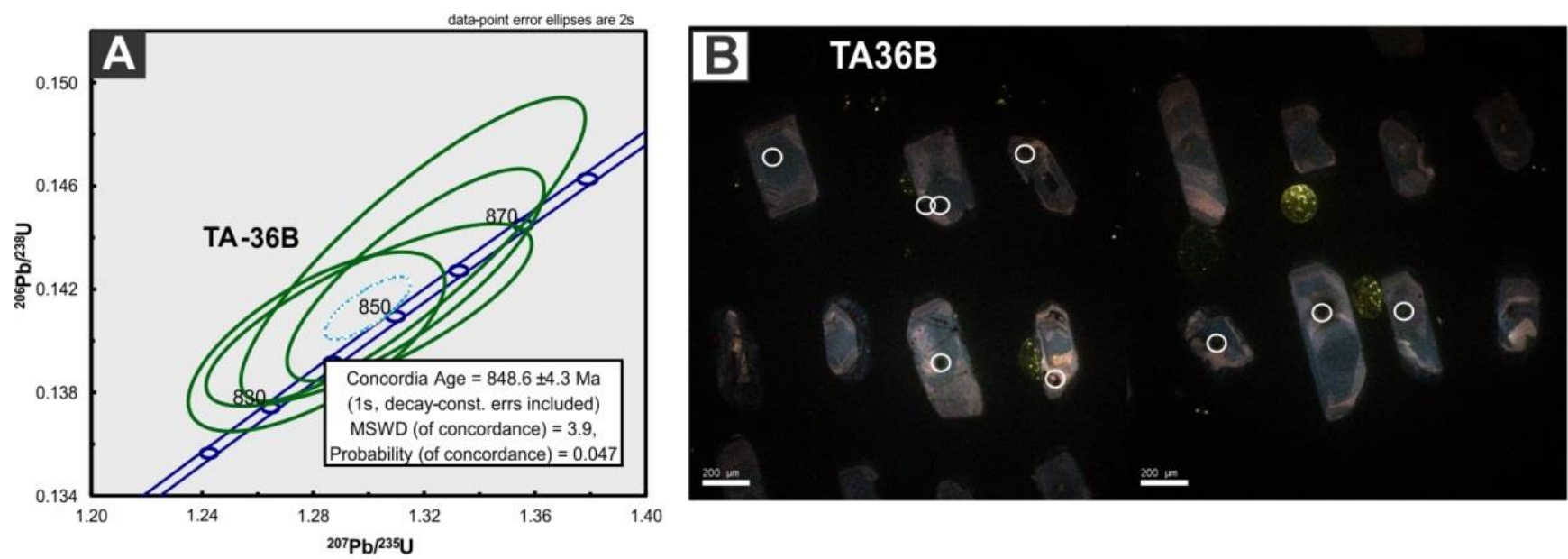

Fig. 5.6 - Diagramas concórdia com as idades de cristalização das rochas do estágio de acresção intra-oceânico. A) concórdia de zircão do afloramento TA36B - Augen gnaisse. Em B) imagens MEV d de zircão. Demais descriçães dos diagramas e imagens no texto.

Estágio da colisão arco-continente - Um segundo conjunto de rochas, cerca de $200 \mathrm{Ma}$ mais jovem, forma uma margem continental ativa desenvolvida no denominado Evento de Acresção Santa Terezinha de Goiás (660-630 Ma). O Arco Continental de Santa Terezinha de Goiás compreende extensos batólitos de forma ovalada, alongados pelos processos deformacionais, distri- 
buindo-se ao longo do orógeno e cortando unidades prévias do arco insular, com múltiplos corpos coalescidos. Está parcialmente exposto na porção centro-leste da área e prolonga-se para sul, por mais de $100 \mathrm{~km}$, até o estado de Goiás. Faz contato a oeste por falhas transpressionais que expõem faixas e núcleos granulíticos, colocando lado a lado dois segmentos de nível crustal distinto; a leste faz contato com dois segmentos do arco insular por falha transcorrente.

Os afloramentos são raros; formam lajedos, principalmente no leito de rios; em geral apresentam-se intemperizados, ou estão cobertos por solos detrito-lateríticos ou coberturas neógenas. As principais rochas são hornblenda-biotita metatonalitos, biotita metatonalitos, hornblenda-biotita metagranodioritos, biotita metagranodioritos, quartzo metadioritos, foliados e gnáissicos, metasienogranitos, granada-biotita gnaisses com autólitos biotíticos e anfibolíticos e enclaves de rochas máficas e metassedimentares. Apresentam estruturas foliadas, bandadas, com granulação muito variável, de grossa a fina, texturas inequigranulares, granoblásticas, grano-nematoblásticas, granolepidoblásticas, porfiroclásticas tipo augen e proto a ultramiloníticas, em lâminas delgadas os gnaisses tonalíticos-granodioríticos exibem texturas variáveis entre granonematoblástica, diablástica, porfiroclástica/milonítica (com porfiroclastos de plagioclásio e quartzo) e porfiroblástica (porfiroblastos de granada e hornblenda), (fig. 5.7).

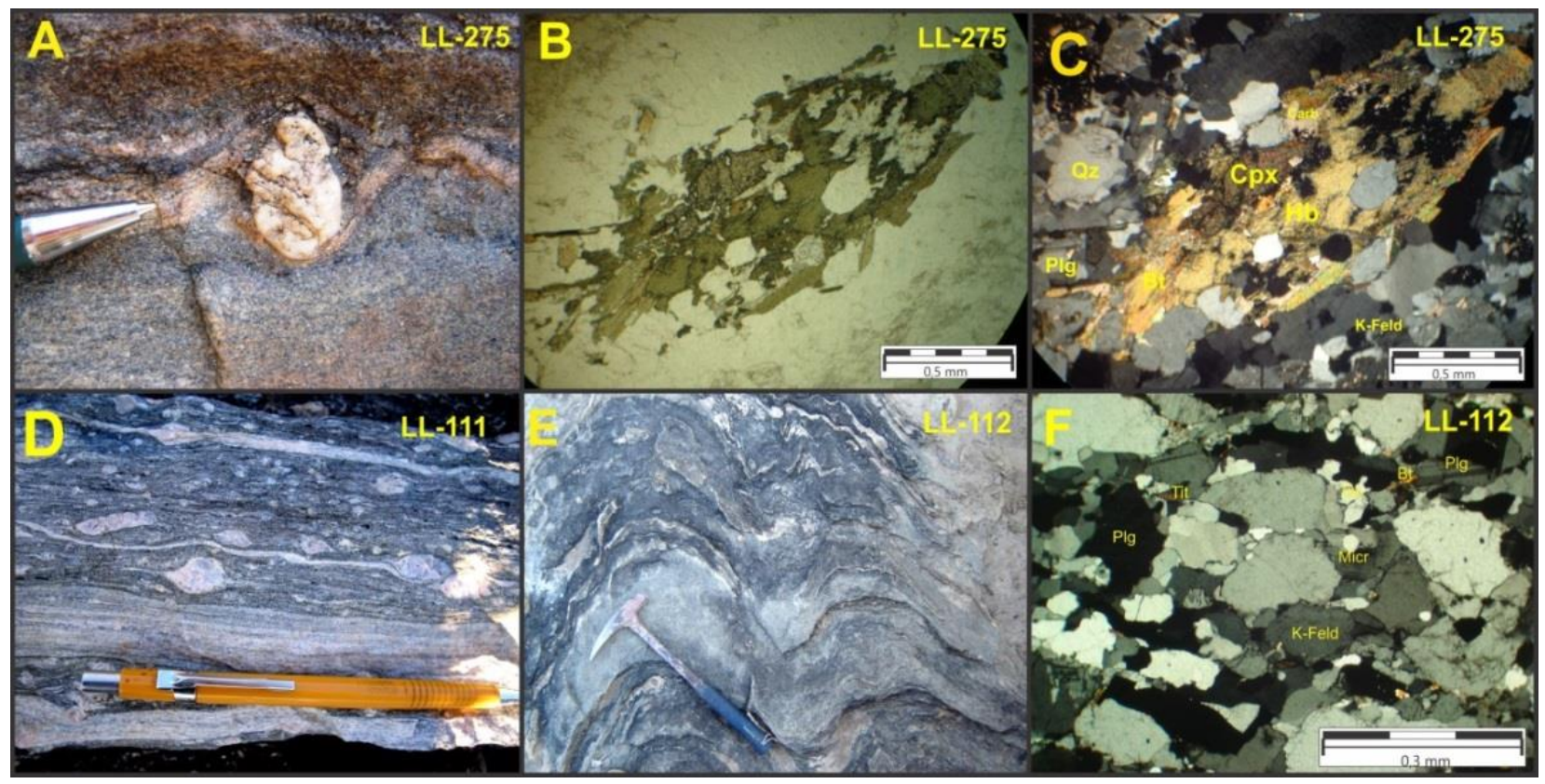

Fig. 5.7 - Padrões de afloramento e fotomicrografias das rochas do estágio de colisão arco-continente. A) Aspecto macro de estiramento mineral em quartzo tipo delta, com cinemática dextral; B) e C) estiramento em hornblenda, a luz. polarizada observa-se processo metamórfico $\mathrm{Cpx}$-Hb superimposto; D) Augen granodiorito-tonalito gnaisses miloniticos, deformação dúctil dextral; E) Gnaisses granodioriticos a monzograniticos dobrados e F) em seção delgada observa-se padrão arqueado, dobras e recristalização com textura decussada. 
Os minerais varietais são biotita ou biotita+ hornblenda. Plagioclásio e K-feldspato são geralmente subédricos com recristalização parcial. A biotita localmente recristaliza-se para clorita.

As estruturas deformacionais impressas são muito penetrativas e materializadas por forte foliação milonítica e/ou no bandamento composicional desenvolvido. Em geral, apresentam atitudes de $\mathrm{N} 20^{0}-30^{\circ} \mathrm{E}$ com mergulhos acentuados ora para NW, ora SE. A deformação é de caráter dúctil, porém grandes sistemas de falhas transcorrentes estão impressas. Nas bandas porfiroclásticas observa-se o estiramento mineral de feldspatos centimétricos com assimetria preferencialmente dextral. A lineação de baixo ângulo tem caimentos de $7^{0}$ para $\mathrm{N} 11^{0} \mathrm{E}$ e $8^{0}$ para $\mathrm{N} 26^{0} \mathrm{E}$.

Uma datação U-Pb em zircão realizada por Praxedes (2014), na continuidade de nosso traçado geológico para Acresção de Santa Terezinha de Goiás, a nordeste da área estudada indicou para um hornblenda metatonalito a idade de 654 4 Ma.

Estágio colisional a pós-colisional - Em sua fase final e de fechamento orogênico o magmatismo é marcado por um grupo de rochas com idades próximas a $594 \mathrm{Ma}$, obtidas em grãos magmáticos e metamórficos zircão formados em evento ediacarano associado à formação de margem continental representada no Arco de Santa Terezinha de Goiás.

As rochas distribuem em vários corpos batolíticos e stocks coalescentes, com grande variedade composicional, alongados e por vezes estirados e controlados por zonas de cisalhamento do LTB. Os contatos são ao longo de falhas transpressionais e transcorrentes em zonas de alta strain, muito próximas umas das outras, gerando no terreno um tipo de mosaico de falhas sigmoidais e interconectadas na direção $\mathrm{N} 20^{\circ} \mathrm{E}$ a N $30^{\circ} \mathrm{E}$. As falhas em geral caracterizam zonas de transpressão é comum a presença de faixas granulíticas.

Predominam hornblenda metatonalito, biotita metagranodioritos e biotita metatonalito ricos em granada (8 até 18\%), miloniticos, com porfiroblastos pré- a sintectônicos, (fig. 5.8). Ocorrem também intrusões e restitos de corpos máficos, metagabros, metadioritos e anfibolitos, intrusões graníticas estiradas, corpos vulcânicos e subvulcânicos com textura pórfira e deformados, expostos e colocados lado a lado. Às vezes apresentam quantidades altas de epidoto, sugerindo a atuação de processos de percolação de fluídos durante os processos deformacionais tardios. A mineralogia principal dos metagranodioritos e metatonalitos é composta de plagioclásio porfiroclástico a porfiroblástico (30\% a $44 \%)$, quartzo ( $25 \%$ a $51 \%$ ), porfiroclástico de K-feldspato ( $25 \%$ a $62 \%$ ), biotita, cristais sincinemáticos de granada e hornblenda (5\% a 20\%). Os minerais acessórios são titanita (até $2 \%$ ), zircão, apatita, magnetita (até 1\%). Clorita é subproduto da substituição da biotita e fengita é produto da alteração dos feldspatos; outros minerais de alteração registrados são epidoto e carbonato. 
Os granulitos se distribuem de forma alongada no corredor do LTB, com aproximadamente 2 a $5 \mathrm{~km}$ de largura, e com mais de $50 \mathrm{~km}$ de comprimento, prosseguindo para NE os principais tipos são: opx granulito, opx-cpx granulito, granada-opx granulito, biotita granulito, granada gnaisses, granulitos máficos, anfibolitos, granada anfibolitos, metagabros, com rochas supracrustais subordinadas. Formam corpos lenticulares, descontínuos e são encontrados com frequência ao longo da foliação milonítica dos gnaisses encaixantes. Os ortogranulitos apresentam textura diablástica, granoblástica, granonematoblástica, constituídos por plagioclásio, ortopiroxênio, hornblenda, quartzo, granada, biotita, zircão e opacos, (Fig. 5.9). O ortopiroxênio é em geral prismático, a hornblenda e biotita são produtos retrometamórficos. Os protólitos são rochas tonaliticas e monzodioríticas.

A tipologia de zircão na maioria é euédrica, prismático, curtos e zonados internamente com uma ampla variação granulométrica entre 200 a 500 m, são todos ígneos, tênues bordas metamórficas são visíveis em alguns zircão. Determinação U-Pb admitidas como idade de cristalização em biotita granito milonítico e metagabro fornecem idades entre $588 \pm 5$ Ma a $578 \pm 6$ Ma, (Fig. 5.10A e B). Amostras de granulitos apresentam idade de $594 \pm 2$ Ma e podem marcar evento metamórfico de alto grau. Apresentam também uma segunda população de zircão herdado com idades em 814+12 Ma.



Fig. 5.8 - Padrões de afloramento e fotomicrografias das rochas do estágio colisional a pós-colisional; A) e B) Detalhe de afloramento de gnaisses tonaliticos em fácies anfibolito; $C$ ) Porfiroclastos de K-feldspatos marcando o estiramento mineral com recristalização de borda e sombra de pressão, rotação dextral; D) fenocristal de K-feldspato com rotação dextral, E) fenoblasto de microclinio e hornblenda em granodioritos; E) pórfiroblastos de granada e G) pórfirclastoss de hornblenda todos apresentando bandas miloníticas com rotação dextral e recristalização. 




Fig. 5.9 - A) a D): Aspecto microscópico dos ortogranulitos com textura diablástica, granoblástica. Possível identificar retrometamorfismo pela desestabilização do Opx para biotita e quartzo.
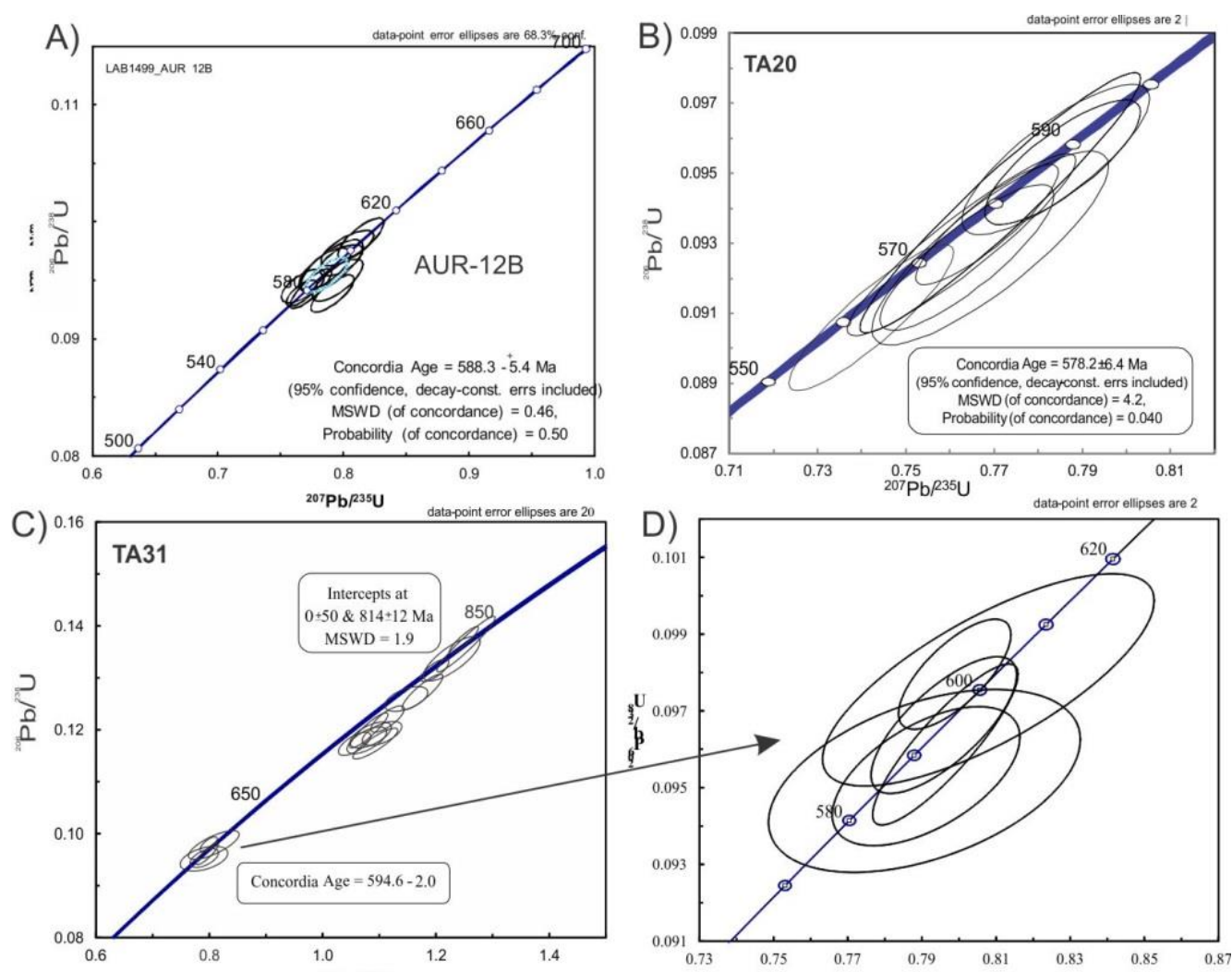

E)

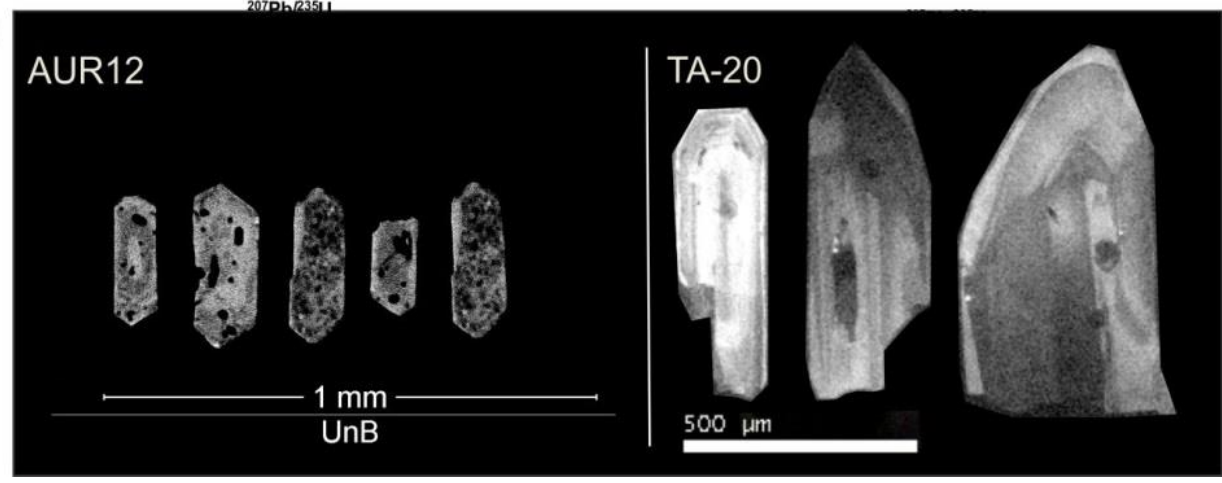

Fig. 5.10 - Diagramas concórdia com as idades de cristalização das rochas do estágio de acresção colisional a póscolisional. Descrições dos diagramas e imagens zircões vide texto.

Estágio de Arco Maduro - Corpos graníticos, deformados a indeformados, também são comuns no arco continental. Apresentam características similares a granitos tardi-orogênicos, com 
idades de cristalização entre 552 e 545 Ma (Gorayeb et al., 2013). São principalmente biotita metamonzogranitos, metagranodioritos e metasienogranitos, com pegmatitos e apófises graníticas finas associadas a diques de composição diorítica e com raros enclaves de rochas vulcânicas máficas e granulitos. Constituem rochas de coloração vermelha a rosa e de tonalidade clara, inequigranulares médias a muito grossas. Os litotipos de granulação mais fina estão restritos a fases tardias.

No interior do LTB há porções isótropas e anisótropas, com texturas porfiríticas e porfiroblásticas compostas por megacristais de feldspato K, estirados em bandamento gnáissico e/ou foliação milonítica a protomilonítica, definindo-os como augen gnaisses. Nos afloramentos observa-se estiramento mineral obliquo de $\mathrm{K}$-feldspatos assimétricos, preferencialmente dextrais, e sinistrais subordinados, com atitude media de $06^{0} / 030^{0}$. Ao microscópio mostram textura porfirítica, geralmente com K-feldspato e plagioclásio como fases porfiríticas e quartzo e biotita como fases intersticiais. A mineralogia é composta de K-feldspato (35-50\%), quartzo (20-38\%), plagioclásio (8-30\%), biotita (5-10\%), hornblenda (0-9\%). Acessórios são granada, muscovita, clorita, turmalina, apatita, epidoto, zircão, carbonato, opacos. Datação U-Pb em zircão apresenta idades de $540 \pm 5$ Ma (Fig. 5.11) e herança em 791 $\pm 8 \mathrm{Ma}$, (Appendix I).

Ocorrem também Intrusões máfico-ultramáficas acamadadas relacionadas aos granitos tardios e adjacentes ao LTB, e marcam o final da Orogenia Brasiliana. São constituídas por rochas anortosíticas interacamadadas com cumulados máficos, incluindo troctolitos, leucotroctolitos, gabronoritos e olivina gabronoritos, com e apresentam idades $\mathrm{U}-\mathrm{Pb}$ em torno de 526 $\underline{5} \mathrm{Ma}$ (Lima, 2007; Lima et al., 2008).



Fig. 5.11 - Diagramas concórdia com as idades de cristalização das rochas do estágio de maturidade do arco. 
Deformação, Metamorfismo e Zonas de Cisalhamento. As modificações em todo conjunto rochoso no LTB e adjacências foram intensas; praticamente todas as unidades foram afetadas por interferências de fases deformacionais que se sobrepõem. Observa-se forte encurtamento crustal, sob cisalhamento puro marcado pela geração de dobras apertadas e formação de xistosidades e bandamento gnáissico. Esta fase é seguida por fase progressiva de transpressão e transcorrência obliqua e de escape lateral, a qual posiciona e acopla o arco intraoceânico e deforma o Maciço de Goiás. Descontinuidades internas do embasamento no Bloco Cavalcante-Natividade são reativadas.

O registro subsequente é mais jovem, coaxial à fase anterior e aproveita as descontinuidades prévias. Possui direção NE é de caráter transcorrente dúctil, de cinemática principal dextral, as transcorrência N/S formam binários antitéticos com a zona principal NE. Esta fase causa o embaralhamento tectônico final e a geometria irregular e sinuosa das zonas de cisalhamento, falhas transpressionais alçam blocos granulíticos profundos a níveis crustais intermediários e expondo lado a lado secções diferentes de crosta.

Estas zonas formam extensas e largas faixas miloníticas marcadas por foliação penetrativa sobreposta a gnaisses e granulitos. São os fatores deformacionais relacionados às principais zonas de cisalhamento do LTB que expõem condições de metamorfismo tão diversas em faixas adjacentes, mostrando fácies metamórficas diferentes, desde granulito a anfibolito e até xisto verde em áreas contiguas.

A deformação no LTB não só coloca níveis crustais diferentes em proximidade, como também acopla blocos e terrenos geotectônicos díspares. Lascas de embasamento, porções do arco de ilhas e continental são entremeadas ao longo de zonas de transcorrências e suturas crustais. A dinâmica iniciada nos processos de convergência crustal levou ao consumo da placa oceânica, formadora do arco insular, utilizando como anteparo o embasamento paleoproterozóico. Seguiu-se a formação de arco continental, reciclando parcialmente o arco de ilhas precedente. A conformação de vários episódios colisionais e de justaposição de blocos retrabalhou unidades pré-existentes, presentemente atrelados no LTB.

Os lineamentos estruturais traçados na (fig. 5.12) representam as foliações miloniticas, bandamentos gnáissicos e xistosidade regional, com seus respectivos domínios quantificados nos estereogramas: A) Domínio Dúctil de Embasamento que marca as estruturas reliquiares de eventos deformacionais mais antigos de direção N/S e duplo caimento, parcialmente transpostos e reativados por sistemas deformacionais mais jovens; B) Domínio Dúctil Compressional Leste que corresponde a duas áreas com registro de encurtamento crustal; C) Domínio Dúctil Compressional- Transpressional Oeste área com eventos de deslocamentos de massa oblíquos e de descolamentos e imbricações de baixo angulo; D) Domínios Dúctil Transcorrente-Central correspondente a área central do LTB, 
com zonas de cisalhamento com mergulhos altos, cinemática dextral, caracterizadas ainda por feições de boudinagem de estruturas previamente dobradas; F) Domínio Rúptil é o sistema mais jovem tardio e de caráter extensional, correspondente a zonas de falhas e fraturas de direção NW, sobreposta a todas unidades. Parte dos domínios caracteriza-se por representar padrões de interferência deformacional, formados em tempos distintos. Alguns são coaxiais e as fases finais e as deformações finais, principalmente associadas às transcorrências do LTB são de grande intensidade e geralmente transpõem estruturas antecedentes.

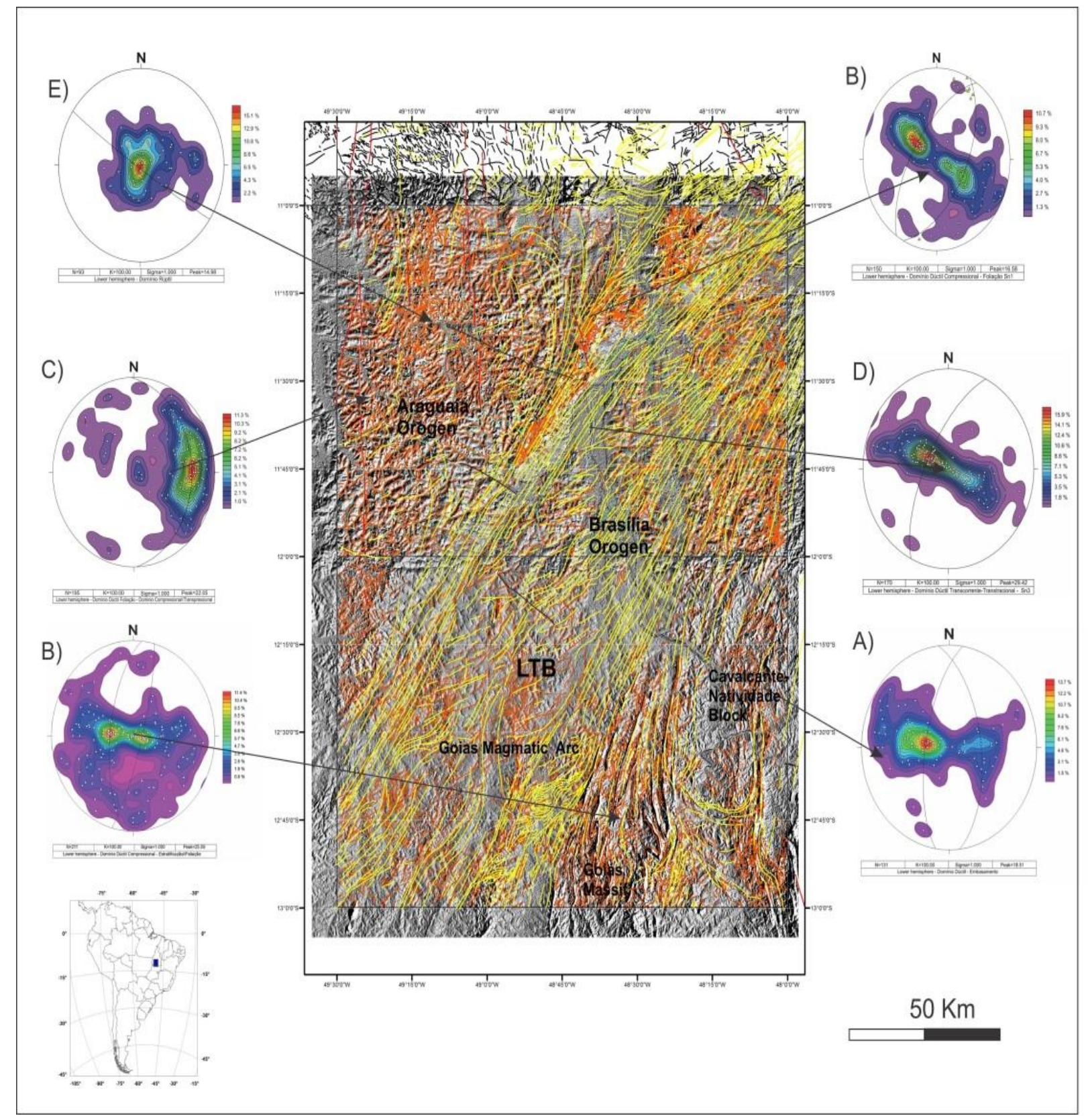

Fig. 5.12 - Estereogramas de domínios sobrepostos à imagem de relevo sombreado indicando geometria e atitude de foliações em áreas de deformação distintas. As letras correspondem aos domínios citados no texto. Estereogramas representam as concentrações das linhas de megulho medidas de campo, os planos traçados configuram os planos modais - Medidas em DIP, hemisfério inferior. 


\subsection{Dados Geoquímicos, Ambiente Geotectônico e Isótopos de Sm-Nd}

Para distinção dos vários conjuntos de rochas, foram utilizados parâmetros químicos de $\mathrm{Nb}$, $\mathrm{Rb} / \mathrm{Zr}, \mathrm{K}_{2} \mathrm{O}, \mathrm{Sr}, \mathrm{Ba}, \mathrm{Zr}, \mathrm{Y}$, Th, U, comparados com áreas orogênicas, incluindo arcos de ilha, arcos maduros e arcos continentais ativos de Candlemas (South Sandwich Islands), Egmont (Nova Zelândia), Azufre (Andes), Cascades e Indonésia. Aplica-se ênfase e tratamento químico serão dados às rochas dos arcos neoproterozóicos.

\subsection{1 - Embasamento}

As rochas do embasamento são dioritos, tonalitos, granodioritos, monzodioritos e monzogranitos. O conteúdo em $\mathrm{SiO}_{2}$ varia de $57.15 \%$ até $75.91 \%$ em peso. Os valores de elementos maiores apresentam valores de $\mathrm{MgO}(0.17 \%-4.76 \%), \mathrm{CaO}(0.94 \%-5.86 \%), \mathrm{K}_{2} \mathrm{O}(1.1 \%-6.34 \%), \mathrm{Na}_{2} \mathrm{O}$ $(2.33 \%-5.51 \%)$ com algumas amostras apresentando valores superiores a $4 \%$.

A razão $\mathrm{K}_{2} \mathrm{O} / \mathrm{Na}_{2} \mathrm{O}$ está em torno de 1.05. Em média, as rochas analisadas são enriquecidas em LILE (Ba 996 ppm, Sr 458 ppm), contêm teores baixos de Rb (91 ppm), valores altos de HFSE (Zr 202 ppm, Y 22 ppm) e ETRL, moderados em Th (12 ppm), e são depletados em Nb, P e ETRP. Diagramas classificatórios de ambiente tectônicos sugerem magmatismo com tendência cálcioalcalina dominante, metaluminosa a fracamente peraluminosa, gerados em ambiente de arco colisional.

\subsection{2 - Arcos Neoproterozóicos}

A tabela 5.2 apresenta a análise química das rochas dos arcos neoproterozóicos. As análises estão arranjadas conforme o padrão cronológico dos eventos magmáticos, onde se identifica as propriedades químicas dos processos de acresção e sua evolução.

Para fins de comparação, foram utilizadas algumas rochas básicas associadas às rochas de arco. A maioria das amostras analisadas é de natureza intermediária a ácida, com teor médio em $\mathrm{SiO}_{2}$ em $67.68 \%$, com mínimo de 55,40\% de e máximo de 77,42\% $\mathrm{SiO}_{2}$.

Estágio de Arco Intra-oceânico - Predominam rochas de composição tonalítica a diorítica com valores de $\mathrm{SiO}_{2}$ em torno de 59.67\%, máximo de 62,94\% e mínimo de 56,76\%, valores médios a altos em $\mathrm{Al}_{2} \mathrm{O}_{3}$ (17.21\% Med., 18,65\% Max., 15.39\% Min.), $\mathrm{Fe}_{2} \mathrm{O}_{3}$ (6.33\% Med., 8.31\% Max., 4,87\% Min.), $\mathrm{MgO}$ (3.41\% Med, 3.96\% Max., 2.93\% Min.) e $\mathrm{Na}_{2} \mathrm{O}$ (4.26\%), com destaque para valores de $\mathrm{CaO}$ acima de $6.00 \%$ e de baixos teores em $\mathrm{K}_{2} \mathrm{O}$ de $1.17 \%$. As análises registram valores 
moderados para rochas intermediárias a ácidas em elementos de transição $\mathrm{Ni}$, Co e V, teores baixos em LILE, Ba (538 ppm), Rb (29 ppm) e Cs (0.7 ppm), moderado a alto em Sr (700 ppm) e valores baixos em todos HFSE, à exceção de $\mathrm{Y}$. As razões $\mathrm{K}_{2} \mathrm{O} / \mathrm{Na}_{2} \mathrm{O}$ são inferiores à unidade, com valores próximos de 0.28 .

Normalizadas para o condrito de (Boynton, 1984) (fig. 5.13A), as rochas apresentam padrões de ETR com baixos a moderados valores em ETRL e depletadas em ETRP. Os ETRL apresentam uma maior amplitude de valores e os de ETRP centrados com razão $[(\mathrm{Dy} / \mathrm{Yb})] \mathrm{n}=1.00 \mathrm{a}$ 1.66 e sem anomalias positivas ou negativas de $\mathrm{Eu}$. A razão $\mathrm{La}(\mathrm{n}) / \mathrm{Yb}_{(\mathrm{n})}$ apresenta razão baixa de 9.49 e com baixo fracionamento. Nos spidergramas normalizados para o manto primitivo (Sun e McDonough, 1989) (fig. 5.13B) as rochas apresentam depleção em Rb, Th, Nb, Pb, P e Ti, com valores próximos à unidade. São levemente enriquecidas em $\mathrm{Ba}, \mathrm{Cs}$ e $\mathrm{Sr}$.

\begin{tabular}{|c|c|c|c|c|c|c|c|c|c|c|c|c|c|c|}
\hline \multicolumn{15}{|c|}{ Basement Rocks } \\
\hline Sample & HL52 & LL-273C & LL-275C & LL-278A & LL-278B & LL-278D & HL 006 & LL 95 & LL 257 & HL 141 & LL 114 & LL 81 & LL-273A & HL 113 \\
\hline Rock & $\begin{array}{l}\text { Bt tonalite } \\
\text { gneiss }\end{array}$ & $\begin{array}{l}\text { Sienogranite } \\
\text { Milonitic }\end{array}$ & $\begin{array}{c}\text { Bt Hb } \\
\text { Granodiorite } \\
\text { gneiss }\end{array}$ & $\begin{array}{l}\text { Augen } \\
\text { Granodiorite } \\
\text { gneiss }\end{array}$ & $\begin{array}{l}\text { Grt Hb } \\
\text { Tonalite } \\
\text { gneiss }\end{array}$ & $\begin{array}{l}\text { Granodiorite } \\
\text { Milonitic }\end{array}$ & $\begin{array}{l}\text { Tonalite } \\
\text { Gneiss }\end{array}$ & Bt tonalite & $\begin{array}{c}G r \\
\text { sienogranite } \\
\text { milonitic }\end{array}$ & $\begin{array}{l}\text { Tonalite } \\
\text { Granodiorite } \\
\text { Milonitic }\end{array}$ & Trondjhemite & $\begin{array}{c}\text { Bt Musc } \\
\text { Ultramilonite }\end{array}$ & $\begin{array}{c}\text { Hb-bt } \\
\text { tonalite } \\
\text { gneiss }\end{array}$ & $\begin{array}{c}\text { Hb BT } \\
\text { Tonalite }\end{array}$ \\
\hline $\mathrm{SiO}_{2}$ & 68.58 & 73.80 & 72.50 & 65.20 & 57.80 & 63.50 & 66.48 & 57.15 & 73.26 & 70.06 & 75.91 & 73.42 & 63.60 & 64.62 \\
\hline $\mathrm{Al}_{2} \mathrm{O}_{3}$ & 16.22 & 13.40 & 14.50 & 15.20 & 15.60 & 14.40 & 14.44 & 16.62 & 12.79 & 15.35 & 12.63 & 14.53 & 15.70 & 16.74 \\
\hline $\mathrm{FeO}$ & 2.79 & 3.81 & 3.59 & 7.54 & 8.41 & 7.48 & 6.50 & 7.37 & 3.58 & 3.18 & 3.31 & 1.59 & 7.65 & 5.10 \\
\hline MgO & 0.78 & 0.37 & 0.17 & 2.88 & 3.84 & 4.76 & 2.00 & 2.70 & 0.74 & 0.94 & 0.40 & 0.42 & 2.76 & 1.11 \\
\hline $\mathrm{CaO}$ & 2.57 & 0.94 & 1.45 & 3.84 & 5.86 & 1.94 & 1.91 & 5.44 & 1.87 & 2.63 & 1.63 & 1.44 & 4.61 & 3.64 \\
\hline $\mathrm{Na}_{2} \mathrm{O}$ & 5.51 & 2.46 & 4.17 & 4.22 & 3.54 & 2.84 & 3.12 & 4.54 & 2.33 & 4.38 & 3.94 & 3.54 & 4.31 & 4.66 \\
\hline $\mathrm{K}_{2} \mathrm{O}$ & 1.49 & 6.34 & 4.31 & 1.94 & 3.59 & 4.47 & 3.14 & 2.12 & 3.39 & 1.55 & 1.10 & 4.79 & 1.46 & 1.93 \\
\hline $\mathrm{TiO}_{2}$ & 0.34 & 0.23 & 0.16 & 0.47 & 0.33 & 0.42 & 0.61 & 1.70 & 0.41 & 0.43 & 0.32 & 0.20 & 0.52 & 0.65 \\
\hline $\mathrm{P}_{2} \mathrm{O}_{5}$ & 0.09 & 0.05 & 0.04 & 0.18 & 0.29 & 0.16 & 0.07 & 0.82 & 0.07 & 0.13 & 0.04 & 0.06 & 0.19 & 0.21 \\
\hline MnO & 0.05 & 0.03 & 0.04 & 0.08 & 0.15 & 0.06 & 0.12 & 0.09 & 0.10 & 0.04 & 0.04 & 0.03 & 0.07 & 0.08 \\
\hline $\mathrm{Cr}_{2} \mathrm{O}_{3}$ & 0.00 & 0,01 & $<0,01$ & 0.01 & 0.02 & 0,01 & 0.01 & 0.01 & 0.00 & 0.00 & 0.00 & 0.00 & 0,01 & 0.00 \\
\hline LOI & 1.00 & 0.34 & 0.73 & 0.80 & 0.98 & 0.98 & 0.60 & 0.80 & 0.90 & 1.00 & 1.00 & 0.30 & 0.63 & 0.50 \\
\hline SUM & 99.74 & 101.49 & 100.56 & 101.51 & 99.22 & 99.83 & 99.75 & 100.18 & 99.85 & 100.05 & 100.69 & 100.50 & 101.03 & 99.82 \\
\hline $\mathrm{Ba}$ & 272.90 & 2307.00 & 1655.00 & 232.00 & 1193.00 & 1095.00 & 1048.30 & 1538.60 & 991.70 & 356.80 & 385.80 & 1346.50 & 459.00 & 1065.10 \\
\hline Co & 4.60 & 2.70 & 1.50 & 14.10 & 17.50 & 29.80 & 17.80 & 17.20 & 6.50 & 6.90 & 3.90 & 2.60 & 15.80 & 7.20 \\
\hline Cs & 6.10 & 0.61 & 0.33 & 1.80 & 0.37 & 1.88 & 2.70 & 0.40 & 1.40 & 1.20 & 0.70 & 1.90 & 1.23 & 1.10 \\
\hline Ga & 24.10 & 12.90 & 16.40 & 20.20 & 24.70 & 19.50 & 23.40 & 23.50 & 16.30 & 24.40 & 15.40 & 16.80 & 20.70 & 23.40 \\
\hline $\mathrm{Hf}$ & 4.30 & 6.32 & 2.66 & 3.13 & 2.75 & 3.50 & 5.20 & 6.10 & 10.00 & 7.60 & 6.80 & 4.00 & 4.74 & 8.20 \\
\hline Nb & 6.50 & 0.31 & 0.33 & 2.52 & 0.15 & 0.05 & 21.30 & 38.10 & 7.50 & 8.40 & 9.40 & 6.80 & 0.79 & 7.60 \\
\hline $\mathbf{R b}$ & 74.40 & 125.10 & 85.00 & 96.80 & 56.90 & 140.60 & 174.40 & 45.20 & 87.50 & 87.30 & 31.60 & 164.10 & 63.20 & 48.60 \\
\hline Sn & 3.00 & 1.40 & 1.10 & 2.00 & 4.90 & 2.40 & 3.00 & 2.00 & $<1$ & $<1$ & 2.00 & 1.00 & 1.80 & $<1$ \\
\hline $\mathrm{Sr}$ & 509.10 & 544.30 & 320.20 & 550.10 & 610.70 & 322.30 & 184.20 & 989.70 & 118.30 & 293.70 & 90.30 & 440.80 & 963.30 & 481.20 \\
\hline Ta & 0.50 & 0.21 & 0.74 & 0.48 & 0.75 & 0.51 & 1.30 & 2.10 & 0.50 & 0.40 & 0.60 & 0.70 & 0.53 & 0.20 \\
\hline Th & 4.70 & 27.20 & 6.80 & 9.30 & 16.50 & 6.30 & 22.60 & 4.80 & 23.60 & 15.20 & 3.40 & 14.80 & 12.40 & 4.80 \\
\hline$u$ & 0.90 & 1.46 & 0.56 & 0.61 & 0.96 & 0.90 & 4.00 & 0.90 & 1.20 & 1.00 & 0.80 & 3.50 & 0.96 & 0.50 \\
\hline v & 30.00 & 14.00 & 4.00 & 60.00 & 59.00 & 68.00 & 91.00 & 88.00 & 23.00 & 27.00 & 16.00 & 22.00 & 61.00 & 33.00 \\
\hline w & 4.20 & 0.30 & 0.40 & 0.50 & 0.90 & 0.30 & 0.10 & 0.20 & 0.40 & 0.40 & 0.20 & 0.30 & 0.40 & 0.20 \\
\hline $\mathrm{Zr}$ & 133.10 & 261.40 & 109.50 & 126.90 & 103.30 & 134.60 & 210.40 & 287.40 & 308.50 & 251.10 & 243.80 & 157.00 & 174.00 & 337.60 \\
\hline $\mathrm{Y}$ & 4.30 & 3.01 & 21.06 & 12.08 & 56.96 & 8.71 & 32.40 & 26.60 & 41.60 & 9.30 & 42.20 & 24.00 & 9.34 & 18.80 \\
\hline Mo & 2.60 & 0.30 & 0.29 & 0.46 & 0.17 & 0.72 & 7.70 & 0.50 & 0.10 & 1.20 & 0.20 & 0.20 & 0.36 & 1.30 \\
\hline $\mathrm{Cu}$ & 3.20 & 11.00 & 5.00 & 7.00 & 26.00 & 7.00 & 33.60 & 31.70 & 6.20 & 5.60 & 31.50 & 22.30 & 31.00 & 3.00 \\
\hline $\mathbf{P b}$ & 2.30 & 2.90 & 2.70 & 9.30 & 4.20 & 3.60 & 2.50 & 2.00 & 4.60 & 1.00 & 0.50 & 4.40 & 2.80 & 1.00 \\
\hline $\mathrm{Zn}$ & 62.00 & 15.00 & 18.00 & 56.00 & 42.00 & 58.00 & 73.00 & 117.00 & 43.00 & 55.00 & 38.00 & 22.00 & 47.00 & 84.00 \\
\hline $\mathrm{Ni}$ & 5.10 & 2.80 & 2.40 & 34.50 & 34.40 & 50.20 & 54.40 & 16.10 & 7.50 & 10.10 & 3.60 & 2.50 & 37.90 & 7.90 \\
\hline La & 26.10 & 18.60 & 23.30 & 33.50 & 39.20 & 40.50 & 70.00 & 106.80 & 63.80 & 56.30 & 17.90 & 39.50 & 44.80 & 38.60 \\
\hline $\mathrm{Ce}$ & 50.50 & 47.80 & 41.60 & 66.10 & 76.80 & 81.70 & 130.60 & 216.00 & 126.50 & 117.60 & 23.50 & 63.90 & 83.70 & 75.70 \\
\hline $\mathrm{Pr}$ & 5.16 & 4.50 & 4.64 & 7.37 & 9.41 & 8.85 & 13.53 & 24.71 & 14.54 & 11.54 & 5.33 & 7.38 & 8.76 & 7.55 \\
\hline Nd & 19.20 & 13.40 & 17.00 & 27.50 & 38.80 & 33.20 & 49.40 & 88.70 & 51.50 & 45.60 & 20.90 & 24.90 & 31.80 & 28.60 \\
\hline $\mathrm{Sm}$ & 2.60 & 2.40 & 3.30 & 5.00 & 9.20 & 5.60 & 7.70 & 12.10 & 9.70 & 7.00 & 4.10 & 4.00 & 4.30 & 5.20 \\
\hline Eu & 0.67 & 0.47 & 0.88 & 1.03 & 1.78 & 1.25 & 1.65 & 3.17 & 0.90 & 1.00 & 0.91 & 0.83 & 1.16 & 1.64 \\
\hline Gd & 1.60 & 1.12 & 3.05 & 3.22 & 10.06 & 3.32 & 5.82 & 8.02 & 8.83 & 3.92 & 4.61 & 3.05 & 2.76 & 3.74 \\
\hline Tb & 0.24 & 0.12 & 0.44 & 0.37 & 1.66 & 0.37 & 0.96 & 1.15 & 1.38 & 0.44 & 0.88 & 0.42 & 0.36 & 0.56 \\
\hline Dy & 0.81 & 0.77 & 3.16 & 2.43 & 10.34 & 1.62 & 5.16 & 4.95 & 7.57 & 1.86 & 5.90 & 2.13 & 1.80 & 3.19 \\
\hline Ho & 0.15 & 0.13 & 0.70 & 0.41 & 2.00 & 0.28 & 1.05 & 0.75 & 1.65 & 0.28 & 1.31 & 0.48 & 0.33 & 0.66 \\
\hline $\mathrm{Er}$ & 0.32 & 0.29 & 2.04 & 1.00 & 5.13 & 0.75 & 3.32 & 2.39 & 4.95 & 0.63 & 4.75 & 1.67 & 0.96 & 1.80 \\
\hline $\mathrm{Tm}$ & $<.05$ & 0.06 & 0.33 & 0.16 & 0.71 & 0.11 & 0.57 & 0.34 & 0.86 & 0.12 & 0.85 & 0.26 & 0.14 & 0.23 \\
\hline Yb & 0.27 & 0.30 & 2.20 & 0.90 & 3.90 & 0.60 & 3.94 & 1.97 & 4.96 & 0.58 & 5.20 & 1.37 & 0.70 & 1.52 \\
\hline Lu & 0.90 & $<0,05$ & 0.26 & 0.11 & 0.51 & 0.06 & 0.40 & 0.40 & & 7.90 & 0.80 & 0.40 & 0.10 & 1.80 \\
\hline
\end{tabular}

Tabela 5.1 - Resultado da análise química das rochas de embasamento do Orógeno Araguaia e Orógeno Brasília - Maciço de Goiás e Bloco Cavalcante-Natividade. 


\begin{tabular}{|c|c|c|c|c|c|c|c|c|c|c|c|c|c|c|c|c|c|c|c|c|c|c|c|c|c|c|c|c|c|c|c|}
\hline \multirow[b]{2}{*}{ Sample } & \multicolumn{7}{|c|}{ Intraoceanic Ar Stage } & \multicolumn{9}{|c|}{ Collisional -Arc Continent Stage } & \multicolumn{7}{|c|}{ Collisional - Pos-Collisional Stage } & \multicolumn{8}{|c|}{ Mature Arc stage } \\
\hline & LL119 & LL 134B & PV 081 & HL 137 & HL 125 & AF 48A & PV 061 & PV 063B & HL 116 & HL 138 & HL 77 & PV15 & LL111 & LL112 & LL.310B & AF-47 & PV 077A & PV 0778 & LL 81 & PV 070 & LL 122 & PV 067 & PV 064 & LL 143 & LL262C & LL273B & LL108 & PV 096B & PV 086 & PV 094 & LL-310A \\
\hline Rocks & az-Diorite & $\begin{array}{l}\text { B.t-bl- } \\
\text { Tonalite }\end{array}$ & Hb Norit & Hb-Tonalite & $\begin{array}{l}\text { Tonalite } \\
\text { Gneiss }\end{array}$ & Hb Tonal & STonalitite & Basalt & 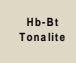 & anodiorite & $\begin{array}{l}\text { Epp.B. } \\
\text { tonalite }\end{array}$ & $\begin{array}{c}\text { Gr. } \\
\text { Grante } \\
\text { Grate }\end{array}$ & 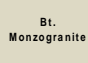 & $\begin{array}{c}\text { Bt. } \\
\text { ranodior } \\
\text { nat }\end{array}$ & nodi & $\begin{array}{c}\text { Hb-Bt } \\
\text { Tranite. } \\
\text { Granodiorite }\end{array}$ & onzogr & onzog. & $\begin{array}{c}\text { Granitit } \\
\text { milonitic }\end{array}$ & $\begin{array}{l}\text { Granodiorit } \\
\text { Gneiss }\end{array}$ & 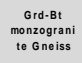 & $\begin{array}{c}\text { Bt. } \\
\text { siengranit } \\
0 \text { G neiss }\end{array}$ & $\begin{array}{c}\text { Bt } \\
\text { Granodiorit } \\
\text { o gne iss }\end{array}$ & $\begin{array}{c}\text { Bt. } \\
\text { anodior }\end{array}$ & 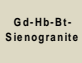 & $\begin{array}{c}\text { sienogranin } \\
\text { milonitic }\end{array}$ & $\begin{array}{c}\text { Bt } \\
\text { nogogra }\end{array}$ & and & $\begin{array}{c}\text { Bt } \\
\text { nograt }\end{array}$ & $\begin{array}{c}\text { Hb-Bl. } \\
\text { sien ngtranito }\end{array}$ & nozogranit \\
\hline SiO2 & 60.86 & 59.07 & 57.05 & 56.76 & 62.94 & 58.40 & 62.62 & 55.40 & 61.97 & 64.63 & 69.51 & 69.36 & 69.65 & 68.01 & 68.80 & 65.18 & 69.99 & 67.89 & 73.42 & 70.01 & 72.86 & 71.36 & 64.22 & 77.42 & 72.53 & 73.00 & 74.67 & 75.87 & 74.73 & 72.92 & 70.80 \\
\hline Al203 & 17.77 & 16.48 & 18.65 & 18.65 & 16.26 & 17.30 & 15.39 & 15.82 & 17.40 & 16.58 & 13.56 & 15.62 & 14.10 & 15.30 & 16.60 & 16.74 & 15.32 & 15.73 & 14.53 & 14.54 & 14.75 & 15.04 & 16.47 & 11.84 & 12.59 & 12.50 & 13.28 & 13.15 & 12.88 & 14.04 & 14.30 \\
\hline $\mathrm{Fe} 203$ & 5.51 & 7.49 & 8.31 & 5.61 & 4.87 & 6.46 & 6.08 & 8.16 & 4.60 & 3.80 & 4.90 & 2.84 & 3.53 & 4.68 & 5.28 & 3.99 & 2.22 & 3.36 & 1.77 & 2.80 & 2.14 & 2.13 & 5.32 & 2.39 & 3.46 & 5.66 & 2.44 & 1.41 & 2.60 & 2.34 & 5.62 \\
\hline $\mathrm{MgO}$ & 2.95 & 3.57 & 3.54 & 3.96 & 2.93 & 3.79 & 3.16 & 3.07 & 2.36 & 1.26 & 1.67 & 1.36 & 1.23 & 1.18 & 0.69 & 1.38 & 0.64 & 0.59 & 0.42 & 0.71 & 0.56 & 0.27 & 0.92 & 0.06 & 0.04 & 0.24 & 0.62 & 0.06 & 0.29 & 0.12 & 0.64 \\
\hline CaO & 6.23 & 6.41 & 7.63 & 6.47 & 5.60 & 6.35 & 6.38 & 5.07 & 4.18 & 3.72 & 3.27 & 2.42 & 2.81 & 3.11 & 3.59 & 3.51 & 1.97 & 1.81 & 1.44 & 1.78 & 1.85 & 1.12 & 2.33 & 0.52 & 1.57 & 1.02 & 1.65 & 0.76 & 1.06 & 0.83 & 1.94 \\
\hline $\mathrm{Na} 20$ & 4.41 & 3.69 & 3.72 & 4.84 & 4.42 & 4.47 & 4.26 & 4.39 & 4.56 & 4.14 & 3.55 & 3.15 & 3.81 & 4.01 & 4.45 & 4.33 & 3.26 & 3.14 & 3.54 & 3.76 & 3.90 & 3.88 & 3.97 & 2.84 & 2.61 & 2.95 & 3.62 & 3.70 & 2.93 & 3.58 & 2.90 \\
\hline K20 & 1.09 & 1.78 & 0.70 & 1.50 & 1.27 & 1.19 & 0.65 & 2.70 & 2.85 & 2.62 & 1.85 & 3.81 & 3.84 & 2.84 & 1.93 & 2.97 & 5.63 & 6.10 & 4.79 & 4.86 & 3.69 & 5.14 & 5.14 & 4.98 & 5.75 & 4.86 & 3.78 & 5.01 & 5.27 & 5.87 & 5.31 \\
\hline Ti02 & 0.79 & 0.82 & 0.64 & 0.68 & 0.60 & 0.77 & 0.50 & 1.71 & 0.76 & 0.43 & 0.62 & 0.46 & 0.58 & 0.51 & 0.30 & 0.61 & 0.37 & 0.58 & 0.20 & 0.56 & 0.23 & 0.25 & 0.75 & 0.20 & 0.22 & 0.31 & 0.32 & 0.09 & 0.33 & 0.17 & 0.44 \\
\hline P205 & 0.21 & 0.23 & 0.13 & 0.28 & 0.24 & 0.36 & 0.13 & 1.10 & 0.33 & 0.20 & 0.16 & 0.14 & 0.17 & 0.14 & 0.10 & 0.24 & 0.14 & 0.23 & 0.06 & 0.16 & 0.07 & 0.09 & 0.28 & 0.02 & 0.03 & 0.07 & 0.09 & 0.03 & 0.07 & 0.03 & 0.10 \\
\hline MnO & 0.08 & 0.13 & 0.12 & 0.17 & 0.08 & 0.13 & 0.09 & 0.11 & 0.06 & 0.08 & 0.06 & 0.03 & 0.06 & 0.09 & 0.05 & 0.05 & 0.03 & 0.02 & 0.03 & 0.03 & 0.02 & 0.04 & 0.06 & 0.03 & 0.03 & 0.04 & 0.04 & 0.02 & 0.04 & 0.03 & 0.05 \\
\hline LOI & 0.60 & 0.80 & 0.10 & 1.10 & 0.90 & 0.40 & 0.70 & 1.80 & 0.50 & 2.50 & 0.70 & 0.20 & 0.60 & 0.60 & 0.38 & 0.60 & 0.50 & 0.30 & 0.30 & 0.50 & 0.50 & 0.60 & 0.30 & 0.40 & 0.70 & 0.40 & 0.20 & 0.30 & 0.10 & 0.40 & 0.57 \\
\hline SiM & 100.51 & 100.48 & 100.10 & 100.04 & 100.13 & 99.63 & 99.98 & 99.34 & 99.58 & 99.96 & 99.87 & 99.40 & 100.38 & 100.47 & 101.36 & 99.60 & 100.07 & 99.76 & 100.50 & 99.71 & 100.57 & 99.92 & 99.76 & 100.70 & 99.53 & 100.21 & 100.71 & 100.40 & 100.30 & 100.33 & 101.48 \\
\hline $\begin{array}{ll}\mathrm{Ni} \\
\end{array}$ & $\begin{array}{l}29.10 \\
\end{array}$ & 24.10 & 5.40 & 31.80 & 38.10 & 15.60 & 28.20 & 14.70 & 26.60 & 9.50 & 31.50 & 17.60 & 11.50 & 6.90 & 4.60 & $\begin{array}{l}11.80 \\
\end{array}$ & 5.00 & 3.10 & 2.50 & 2.90 & 4.90 & 2.00 & 7.60 & $\begin{array}{l}1.70 \\
\end{array}$ & 0.90 & 3.50 & 7.20 & 0.90 & 1.40 & 1.50 & $\begin{array}{l}4.70 \\
\end{array}$ \\
\hline $\mathrm{C}_{0}$ & 17.40 & 20.10 & 25.60 & 19.50 & 16.80 & 18.60 & 20.70 & 20.10 & 15.10 & 6.00 & 11.40 & 6.50 & 6.90 & 7.80 & 3.80 & 9.40 & 3.60 & 5.70 & 2.60 & 4.20 & 3.00 & 1.70 & 6.80 & $<.5$ & 0.80 & 2.70 & 3.70 & $<.5$ & 1.90 & 0.90 & 4.60 \\
\hline $\mathrm{v}$ & 111.00 & 145.00 & 176.00 & 140.00 & 103.00 & 88.00 & 97.00 & 101.00 & 62.00 & 62.00 & 93.00 & 55.00 & 47.00 & 33.00 & 21.00 & 35.00 & 23.00 & 22.00 & 22.00 & 35.00 & 13.00 & 9.00 & 30.00 & $<5$ & $<5$ & 17.00 & 24.00 & $<5$ & 11.00 & 5.00 & 30.00 \\
\hline Ba & 404.60 & 538.40 & 224.80 & 843.70 & 363.00 & 1243.10 & 155.20 & 3046.30 & 1814.70 & 1190.70 & 524.40 & 1064.60 & 1055.60 & 1136.40 & 769.00 & 2614.50 & 1435.60 & 2510.40 & 1346.50 & 1557.10 & 1174.60 & 45.80 & 1392.80 & 259.60 & 2438.10 & 787.00 & 365.70 & 92.50 & 347.30 & 139.80 & 1319.00 \\
\hline Cs & 0.70 & 1.40 & 0.70 & 0.40 & 1.30 & 0.50 & 0.20 & 1.10 & 0.60 & 1.50 & 1.90 & 0.50 & 1.60 & 1.80 & 0.76 & 1.10 & 3.10 & 2.90 & 1.90 & 0.70 & 1.80 & 11.60 & 6.10 & 7.30 & 0.60 & 1.12 & 3.10 & 0.40 & 3.50 & 0.70 & 2.07 \\
\hline Ga & 17.80 & 19.40 & 18.50 & 23.70 & 18.00 & 22.60 & 17.20 & 22.60 & 22.40 & 21.50 & 15.20 & 19.30 & 17.60 & 20.60 & 19.30 & 20.50 & 22.90 & 24.70 & 16.80 & 20.40 & 17.80 & 23.60 & 24.40 & 26.90 & 26.60 & 19.40 & 16.80 & 25.30 & 19.90 & 25.70 & 16.60 \\
\hline Hf & 3.10 & 3.80 & 1.90 & 1.80 & 2.70 & 7.40 & 2.40 & 7.10 & 5.40 & 3.00 & 5.00 & 7.20 & 5.80 & 6.70 & 4.91 & 6.10 & 8.30 & 14.60 & 4.00 & 9.80 & 4.40 & 7.50 & 9.60 & 12.40 & 17.80 & 8.31 & 4.50 & 5.50 & 9.40 & 7.10 & 8.71 \\
\hline $\mathrm{Nb}$ & 5.90 & 8.10 & 5.00 & 8.60 & 6.50 & 8.80 & 2.80 & 42.40 & 12.10 & 10.10 & 10.00 & 6.40 & 26.90 & 9.90 & 1.03 & 9.80 & 7.30 & 29 & 6.80 & 8.9 & 7.20 & 32.80 & 20.00 & 39.20 & 4.50 & 2.20 & 24. & 10.40 & 15000 & 16.20 & 1.95 \\
\hline $\mathrm{Rb}$ & 27.30 & 53.10 & 14.50 & 32.70 & 43.30 & 21.50 & 11.10 & 50.30 & 53.80 & 77.50 & 58.50 & 101.40 & 133.70 & 85.30 & 67.00 & 46.40 & 187.60 & 232.10 & 164.10 & 165.20 & 104.40 & 256.80 & 174.70 & 229.60 & 189.80 & 163.60 & 203.70 & 160.90 & 167.00 & 172.60 & 174.90 \\
\hline $\mathrm{Sr}$ & 541.70 & 421.50 & 422.50 & 1335.20 & 621.70 & 1283.30 & 274.50 & 1566.30 & 1164.00 & 786.10 & 284.00 & 426.30 & 367.30 & 556.00 & 841.40 & 923.80 & 606.60 & 1263.70 & 400.80 & 369.30 & 224.70 & 121.60 & 288.60 & 32.50 & 317.00 & 167.90 & 166.00 & 21.10 & 79.60 & 25.90 & 306.00 \\
\hline Та & 0.40 & 0.60 & 0.40 & 0.20 & 0.40 & 0.40 & 0.20 & 2.10 & 0.70 & 0.60 & 0.70 & 0.20 & 2.80 & 0.70 & 0.82 & 0.50 & 0.40 & 1.80 & 0.70 & 0.60 & 0.50 & 4.80 & 1.10 & 2.60 & 3.50 & 1.98 & 3.70 & 0.60 & 1.30 & 0.60 & 7.06 \\
\hline Th & 1.10 & 3.50 & 2.20 & 0.30 & 4.20 & 4.30 & 0.60 & 8.30 & 6.20 & 4.00 & 5.50 & 27.10 & 16.00 & 5.50 & 5.70 & 6.00 & 54.00 & 119.10 & 14.80 & 36.90 & 15.00 & 28.40 & 7.50 & 25.60 & 44.90 & 31.90 & 23.70 & 8.80 & 23.80 & 12.60 & 33.60 \\
\hline $\mathrm{U}$ & 0.40 & 2.10 & 0.50 & 0.10 & 1.40 & 0.90 & 0.10 & 1.50 & 0.70 & 1.90 & 1.40 & 1.00 & 2.40 & 0.70 & 0.60 & 0.90 & 3.20 & 5.20 & 3.50 & 1.30 & 1.70 & 10.30 & 1.90 & 6.70 & 5.30 & 2.88 & 6.70 & 3.10 & 3.90 & 2.20 & 3.72 \\
\hline w & 0.20 & 0.50 & 0.20 & 0.20 & 0.10 & 0.10 & 0.20 & 0.80 & 0.20 & 0.30 & 0.20 & 0.10 & $<1$ & 0.10 & 1.30 & 0.10 & 0.20 & 0.20 & 0.30 & 0.80 & 0.20 & 0.30 & 0.80 & 0.70 & 0.90 & 0.50 & 0.20 & 0.10 & 0.30 & $<.1$ & 5.40 \\
\hline $\mathrm{Zr}$ & 123.10 & 152.60 & 64.80 & 68.20 & 97.90 & 279.90 & 10580 & 301.90 & 190.70 & 114.30 & 162.50 & 258.20 & 208.80 & 243.10 & 200.90 & 258.00 & 272.20 & 491.00 & 157.00 & 372.20 & 155.40 & 196.70 & 354.50 & 352.60 & 601.10 & 318.90 & 144.60 & 114.80 & 274.60 & 203.90 & 352.30 \\
\hline $\mathrm{Y}$ & 13.40 & 26.20 & 14.00 & 24.60 & 16.70 & 17.10 & 12.40 & 20.50 & 10.10 & 15.40 & 22.20 & 11.70 & 22.00 & 25.00 & 8.56 & 13.30 & 11.50 & 10.30 & 24.00 & 9.30 & 15.20 & 73.00 & 26.80 & 93.00 & 65.50 & 18.16 & 14.00 & 38.50 & 50.90 & 39.00 & 37.07 \\
\hline Mo & 0.20 & 0.30 & 0.40 & 1.20 & 1.80 & 1.10 & 0.10 & 0.80 & 1.20 & 1.40 & 1.40 & 1.80 & 0.30 & 0.20 & 0.35 & 1.00 & 0.30 & 0.40 & 0.20 & 0.20 & 0.20 & 0.20 & 2.20 & 2.10 & 2.10 & 0.90 & 0.60 & 0.30 & 0.80 & 1.60 & 1.05 \\
\hline $\mathrm{Cu}$ & 89.50 & 38.40 & 18.90 & 5.50 & 45.80 & 13.20 & 23.70 & 13.60 & 13.50 & 9.20 & 178.70 & 12.10 & 13.50 & 3.40 & 7.00 & 3.30 & 2.90 & 5.10 & 22.30 & 22.10 & 3.60 & 2.50 & 14.10 & 5.80 & 44.80 & 6.00 & 11.20 & 1.40 & 3.90 & 4.50 & 7.00 \\
\hline Pb & 0.60 & 1.10 & 0.70 & 0.70 & 0.90 & 0.80 & 0.30 & 3.80 & 0.80 & 2.20 & 0.80 & 1.40 & 2.20 & 2.10 & 2.00 & 0.90 & 9.70 & 12.70 & 4.40 & 3.50 & 3.00 & 5.30 & 2.40 & 7.00 & 13.90 & 7.00 & 3.30 & 3.30 & 2.30 & 2.30 & 4.10 \\
\hline $\mathrm{Zn}$ & 40.00 & 51.00 & 17.00 & 61.00 & 36.00 & 40.00 & 32.00 & 137.00 & 46.00 & 57.00 & 39.00 & 29.00 & 40.00 & 56.00 & 50.00 & 49.00 & 34.00 & 51.00 & 22.00 & 64.00 & 36.00 & 49.00 & 91.00 & 76.00 & 80.00 & 59.00 & 30.00 & 51.00 & 42.00 & 73.00 & 37.00 \\
\hline La & $\begin{array}{ll}10.20 \\
\end{array}$ & 20.00 & $\begin{array}{l}10.30 \\
\end{array}$ & 22.60 & 29.20 & 41.30 & 8.30 & 139.30 & 53.40 & $\begin{array}{l}19.60 \\
\end{array}$ & 29.20 & 67.10 & 55.30 & 40.00 & 34.60 & 36.40 & 117.40 & 330.10 & $\begin{array}{l}39.50 \\
\end{array}$ & 97.80 & 29.10 & 31.80 & 54.40 & $\begin{array}{l}94.10 \\
\end{array}$ & $\begin{array}{l}349.00 \\
\end{array}$ & 41.7 & $\begin{array}{l}30.80 \\
\end{array}$ & 19.00 & 126.10 & $\begin{array}{l}56.40 \\
\end{array}$ & 83.10 \\
\hline $\mathrm{Ce}$ & 21.20 & 40.50 & 21.40 & 54,40 & 59.00 & 90.40 & 15.20 & 250.00 & 97.00 & 41.10 & 62.30 & 134.90 & 105.70 & 87.40 & 60.10 & 80.60 & 213.20 & 526.70 & 63.90 & 167.50 & 49.90 & 76.40 & 84.90 & 180.80 & 613.60 & 88.10 & 57.70 & 47.00 & 230.60 & 134.70 & 151.50 \\
\hline Pr & 2.64 & 4.90 & 2.46 & 6.56 & 6.28 & 9.87 & 2.11 & 26.92 & 9.55 & 4.22 & 7.02 & 14.39 & 10.92 & 9.21 & 6.12 & 8.34 & 21.52 & 54.57 & 7.38 & 17.51 & 5.43 & 7.00 & 12.60 & 25.79 & 64.95 & 9.62 & 6.06 & 6.51 & 26.94 & 16.94 & 15.17 \\
\hline Nd & 11.20 & 19.40 & 11.60 & 30.50 & 26.70 & 40.60 & 8.60 & 95.20 & 34.00 & 18.10 & 28.00 & 56.30 & 36.50 & 34.40 & 20.50 & 30.70 & 70.60 & 165.70 & 24.90 & 57.80 & 18.50 & 27.00 & 48.60 & 98.30 & 213.60 & 32.20 & 18.40 & 29.10 & 90.80 & 70.70 & 50.50 \\
\hline Sm & 2.40 & 3.90 & 2.20 & 6.60 & 5.10 & 7.00 & 2.30 & 12.70 & 5.20 & 3.70 & 5.20 & 8.60 & 5.60 & 5.30 & 3.30 & 5.30 & 8.20 & 18.30 & 4.00 & 7.20 & 3.10 & 6.70 & 10.00 & 19.40 & 33.30 & 5.4 & 3.00 & 8.80 & 14.00 & 14.40 & 8.40 \\
\hline Eu & 0.94 & 1.11 & 0.78 & 1.49 & 1.38 & 1.89 & 0.79 & 3.45 & 1.50 & 1. & 1.16 & 1.40 & 1.23 & 1.40 & 0. & 1. & 1.66 & 3 & 0.83 & 1. & 0.93 & 0.73 & 1.82 & 0.53 & 3.00 & 0.67 & 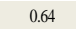 & 0.11 & 66 & 0.25 & 1.13 \\
\hline Gd & 2.55 & 3.60 & 2.47 & 5.06 & 3.65 & 4.29 & 2.26 & 7.21 & 2.84 & 2.95 & 3.93 & 4.93 & 4.81 & 4.11 & 2.13 & 3. & 4.24 & 6.52 & 3.05 & 4.18 & 2. & 6.84 & 8.06 & 16.28 & 17.93 & 4.12 & 2.34 & 8.47 & 9.44 & 11.46 & 6.41 \\
\hline Tb & 0.46 & 0.55 & 0.38 & 0.77 & 0.52 & 0.59 & 0.38 & 0.5 & 0.38 & 0 & 0. & 0.6 & 0. & 0. & 0. & 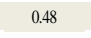 & . & 0. & 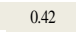 & 0 & 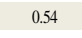 & 1. & & 2.80 & 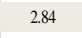 & & 0.36 & 1.50 & 1.44 & 1.71 & 1.02 \\
\hline Dy & 2.32 & 3.89 & 2.35 & 4.21 & 2.74 & 2.90 & 2.02 & 3.98 & 1.79 & 2.54 & 3.92 & 2.59 & 3.82 & 4.23 & 1.28 & 2.44 & 2.42 & 2.95 & 2.13 & 2.11 & 2.98 & 8.97 & 5.32 & 16.98 & 13.78 & 3.08 & 1.76 & 8.77 & 8.43 & 9.25 & 5.74 \\
\hline Но & 0.45 & 0.84 & 0.55 & 0.83 & 0.51 & 0.55 & 0.48 & 0.72 & 0.33 & 0.47 & 0.78 & 0.43 & 0.63 & 0.80 & 0.26 & 0.47 & 0.37 & 0.27 & 0.48 & 0.37 & 0.47 & 2.06 & 0.85 & 3.35 & 2.33 & 0.56 & 0.37 & 1.59 & 1.56 & 1.46 & 1.13 \\
\hline Er & 1.34 & 2.80 & 1.38 & 2.32 & 1.32 & 1.48 & 1.33 & 1.87 & 0.97 & 1.39 & 2.14 & 1.00 & 2.11 & 2.49 & 0.81 & 1.32 & 1.03 & 0.53 & 1.67 & 0.77 & 1.50 & 6.56 & 2.63 & 10.23 & 5.88 & 1.59 & 1.34 & 4.12 & 4.59 & 3.68 & 3.55 \\
\hline $\mathrm{Tm}$ & 0.20 & 0.4 & 0.2 & 0. & 0.2 & 0. & 0.19 & 0.2 & 0.12 & 0 . & 0.35 & 0.14 & 0.28 & 0.37 & 0.15 & 0.1. & 0. &  & 0.26 & 0.12 & 0. & 0. & 0 & 1.58 & 0.87 & 0.21 & 0.24 & 0.55 & 0.71 & 0.54 & 0.57 \\
\hline Yb & 1.11 & 2.50 & 1.42 & 2.23 & 1.07 & 1.37 & 1.26 & 1.53 & 0.78 & 1.58 & 1.95 & 0.88 & 1.77 & 2.37 & 0.70 & 1.14 & 1.03 & 0.60 & 1.37 & 0.73 & 1.12 & 5.81 & 2.00 & 11.44 & 5.06 & 1.60 & 1.26 & 3.35 & 4.31 & 3.45 & 3.50 \\
\hline Lu & 0.30 & 0.30 & 0.00 & 0.60 & 0.60 & 0.80 & 0.00 & 0.00 & 2.20 & 2.80 & 1.10 & 0.40 & 0.60 & 1.00 & 0.10 & 3.50 & 0.00 & 0.00 & 0.40 & 0.00 & 0.50 & 0.00 & 0.00 & 0.00 & 0.00 & 0.18 & 1.00 & 0.00 & 0.00 & 0.00 & 0.46 \\
\hline
\end{tabular}

Tabela 5.2 - Resultado da análise química das rochas dos arcos neoproterozóicos do Orógeno Brasília diferenciados por estágios tectônicos. 
Estágio Colisão Arco-Continente - As rochas classificadas no estagio transicional são principalmente tonalitos, granodioritos e um andesito, que apresentam teores de $\mathrm{SiO}_{2}$ em torno de 65.83\% em peso (Max.69.65\%; Min.55.40\%), valores moderados em $\mathrm{Al}_{2} \mathrm{O}_{3}$ (Med.15.75\%, Max.17.40\%; Min.13.56\%), $\mathrm{Fe}_{2} \mathrm{O}_{3}$ (Med. 4.64\%, Max. 8.16\%, Min. 2.84\%), $\mathrm{MgO}$ (Med.1.58\% Max. 3.07\%, Min. 0.69\%) e $\mathrm{CaO}$ (Med.3.52\%, Max. 5.07\%, Min. 2.42\%). $\mathrm{Na}_{2} \mathrm{O}$ mantem-se moderado a alto (Med. 4.04\%) e $\mathrm{K}_{2} \mathrm{O}$ (Med. 2.82\%) intermediário, com razão $\mathrm{K}_{2} \mathrm{O} / \mathrm{Na}_{2} \mathrm{O}$ próxima à unidade $(0.72)$.

Os valores são moderados em elementos de transição Co, Ni e V. Os LILE apresentam índices médios elevados em Ba (Med.1468 ppm), Sr (Med.768 ppm), moderado a baixo em $\mathrm{Pb}$ (Med.1.8 ppm), baixos em Rb (Med. 74 ppm) e Cs (Med. 121 ppm), baixos a moderados nos elementos HFSE Nb (Med. 14 ppm), Hf (Med. 5.6 ppm), Th (Med. 9,37 ppm), elevados em Zr (Med. 215 ppm) e Y (Med. 16.5 ppm).

Normalizados para o condrito de (Boynton, 1984) as curvas de ETR (fig. 5.13C) são muito enriquecidas em ETRL e com valores baixos de ETRP, ambos com grande amplitude entre máximos e mínimos. Algumas amostras apresentam discretas anomalias negativas de Eu. A razão $\mathrm{La}_{(\mathrm{n})} / \mathrm{Yb}_{(\mathrm{n})}$ é moderada a alta e da ordem de 30.39 , evidenciando princípio de fracionamento, gerando curvas francamente assimétricas. Normalizados para o manto primitivo (Sun e McDonough, 1989) (fig. 5.13D), mostram valores elevados de LILE e assinaladas depleções em HFSE. Em geral, enriquecem-se em $\mathrm{Ba}, \mathrm{K}, \mathrm{Sr}, \mathrm{Nd}$, com anomalias negativas marcantes em $\mathrm{Nb}, \mathrm{Pb}, \mathrm{P}, \mathrm{Ti}$, indicando processos associados a subducção.

Estágio colisional a Pós-Colisional - A assinatura química das rochas desta etapa é distinta, representando processo geodinâmico bem mais jovem e aumento da maturidade química. Representam granodioritos, granitos e adaquitos que possuem teores médios de $\mathrm{SiO}_{2}$ em torno de $69.96 \%$ (intervalo de $73.42 \%$ - 64.22\%) em peso. Os demais óxidos em média apresentam teores moderados de $\mathrm{Al}_{2} \mathrm{O}_{3}$ em 15,2\%, diminuição acentuada nos valores de $\mathrm{Fe}_{2} \mathrm{O}_{3}(2.82 \%), \mathrm{MgO}(0.59 \%)$ e $\mathrm{CaO}$ (1.76\%), aumento significativo em $\mathrm{K}_{2} \mathrm{O}$ (em torno de 5.05\%), tornando a razão $\mathrm{K}_{2} \mathrm{O} / \mathrm{Na}_{2} \mathrm{O}$ com valores médios de 1.41, embora ainda ocorram rochas com valores próximas à unidade .

Normalizados para condrito (Boynton, 1984), (fig. 5.13E) granodioritos e granitos têm padrões de ETR que apresentam enriquecimento em ETRL e relativa depleção de ETRP, com anomalias negativas de $\mathrm{Eu}$ em algumas amostras. A razão $\mathrm{La}_{(\mathrm{n})} / \mathrm{Yb}_{(\mathrm{n})}$ apresentando valores médios com grande dispersão, desde 3.69 até 370. As curvas de ETR apresentam padrões assimétricos, enriquecidos em ETRL, depletados em ETRP, ambos com grande dispersão.

Apresentam LILE com teores variáveis, elevados em Ba (1408 ppm), Cs (4 ppm), K, crescentes em Pb (5.86 ppm), moderados em Rb (183 ppm) e reduzidos em $\mathrm{Sr}$ (473 ppm). HFSE apre- 
sentam indicadores elevados para $\mathrm{Nb}(6.14 \mathrm{ppm})$, Th (39.39 ppm), U (3.87 ppm), Zr (285 ppm), Y (24.3 ppm) e ETRL. No spidergrama de Sun e McDonough (1989), (fig. 5.13F), normalizado ao manto primitivo, apresentam em geral valores elevados de alguns LILE e HFSE como Cs, Rb, Ba, Th, La, com anomalias positivas em Th, La, $\mathrm{K}$ e Zr e padrões negativos em $\mathrm{Ba}, \mathrm{Nb}, \mathrm{P}$ e Ti bem pronunciados. Os padrões de ETRL, LILE e HFSE observados para as amostras são semelhantes às rochas formadas em arco continental.

Estágio de Arco Maduro - São principalmente rochas graníticas, com alguns tipos muito fracionados e evoluídos com teores médios de $\mathrm{SiO}_{2}$ mais elevados, cerca de $73.99 \%$ (intervalo de $77.42 \%$ - 70.80\%) em peso. Os óxidos apresentam teores de $\mathrm{Al}_{2} \mathrm{O}_{3}$ em $13.07 \%$, de $\mathrm{Fe}_{2} \mathrm{O}_{3}$ em $3.24 \%$, queda considerável nos valores de $\mathrm{MgO}(0.26 \%)$ e $\mathrm{CaO}(1.17 \%), \mathrm{Na}_{2} \mathrm{O}(3.14 \%)$ e aumento em $\mathrm{K}_{2} \mathrm{O}$ (em torno de $5.10 \%$ ) tornando a razão $\mathrm{K}_{2} \mathrm{O} / \mathrm{Na}_{2} \mathrm{O}$ com quociente alto (1.66), podendo atingir esta relação, índices acima de 1.8. Este efeito reproduz na petrografia o aumento em ortoclásio, microclínio e biotita sobre albita e anortita.

O comportamento dos REE segue os demais elementos traços, com valores altos e amplos em ETRL e ETRP, curvas menos assimétricas enriquecidas em ETRL e marcadas anomalias negativas de Eu, conforme normalizadas para o condrito de Boynton (1984), (fig. 5.13G). Valores de LILE decaem para Ba (718 ppm), Cs (2.35 ppm), Rb (182 ppm) e Sr (139 ppm). Normalizados contra o manto primitivo de Sun e McDonough (1989), (fig. 5.13H), apresentam LILE com valores elevados e dispersos em $\mathrm{Cs}$, elevados em $\mathrm{Rb}$ e $\mathrm{K}$, amplos em $\mathrm{Pb}$, registrando fortes anomalias negativas em $\mathrm{Ba}, \mathrm{Nb}, \mathrm{Sr}, \mathrm{P}$, Ti.

No diagrama AFM de Irvine e Baragar (1971) modificado por Brown (1982), (fig. 5.14A) mostra que a maior parte das amostras tende ao campo calci-alcalino e com diferentes assinaturas de maturidade para cada estágio. O diagrama ternário $\mathrm{Na}_{2} \mathrm{O}-\mathrm{K}_{2} \mathrm{O}-\mathrm{CaO}$ (Barker \& Arth, 1976; Titley \& Beane, 1981) (fig. 5.14B) confirma a tendência e separa as rochas geradas em arco de ilhas das originadas em margens continentais desde fases transicionais precoces a maturidade química com enriquecimento de $\mathrm{K}_{2} \mathrm{O}$.

Nos diagramas de ambientação tectônica (Pearce et al., 1984; Batchelor e Bowden, 1985; (fig. 5.15 A e B) as rochas indicam a gênese em arcos vulcânicos desde pré a sin-colisionais. O diagrama $\mathrm{Na}_{2} \mathrm{O}-\mathrm{K}_{2} \mathrm{O}-\mathrm{CaO} \times \mathrm{SiO}_{2}$, (Frost et al., 2001), (fig. 5.15C) delineia as amostras no trend evolutivo das mais primitivas para as de maior maturidade. Esta maturidade das diferentes fases de acresção é bem evidente no gráfico com os Índices de Shand. 

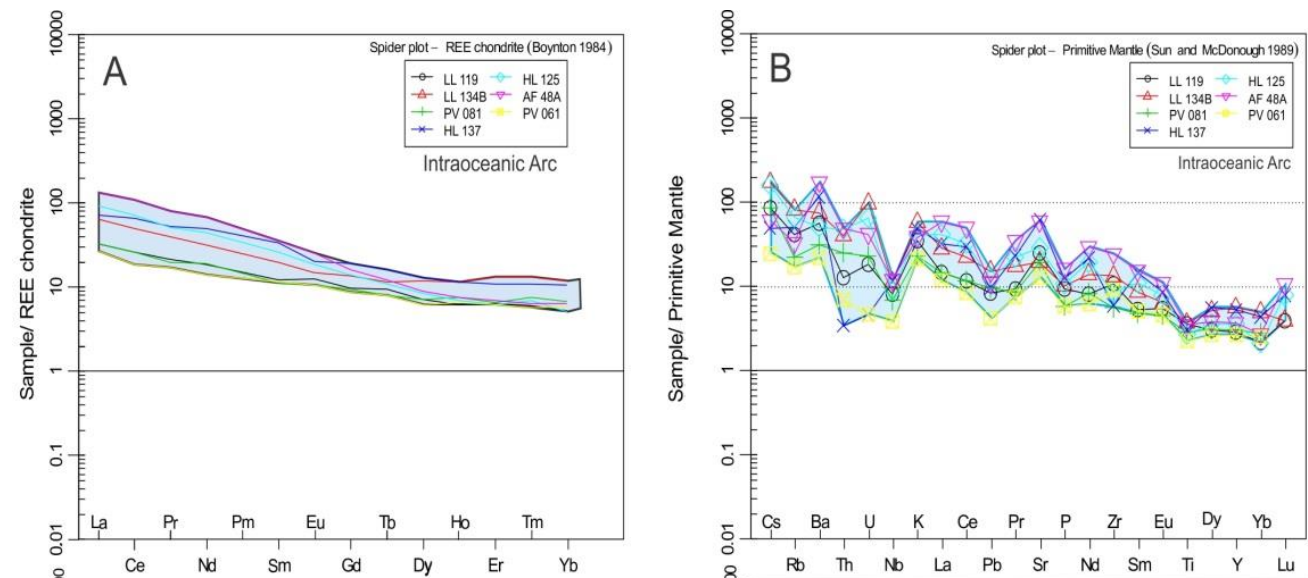

\section{Stages}

$848+4-810+4 \mathrm{Ma}$
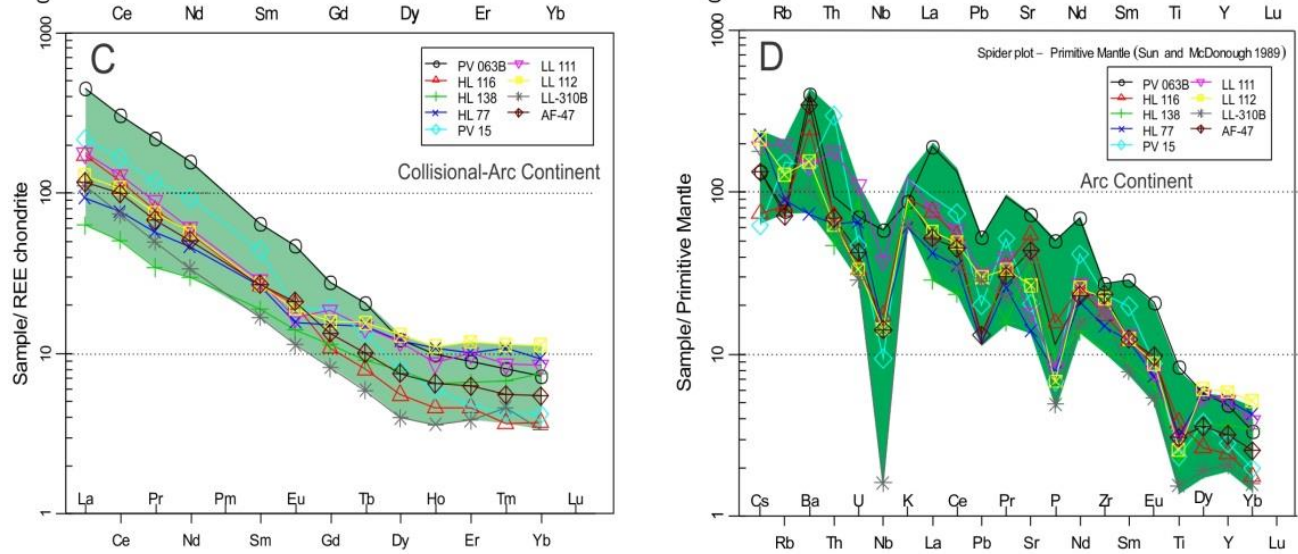

Arc - Continent

$654 \pm 4 \mathrm{Ma}$ (Praxedes, 2014)

$637 \pm 5-615 \pm 7 \mathrm{Ma}$
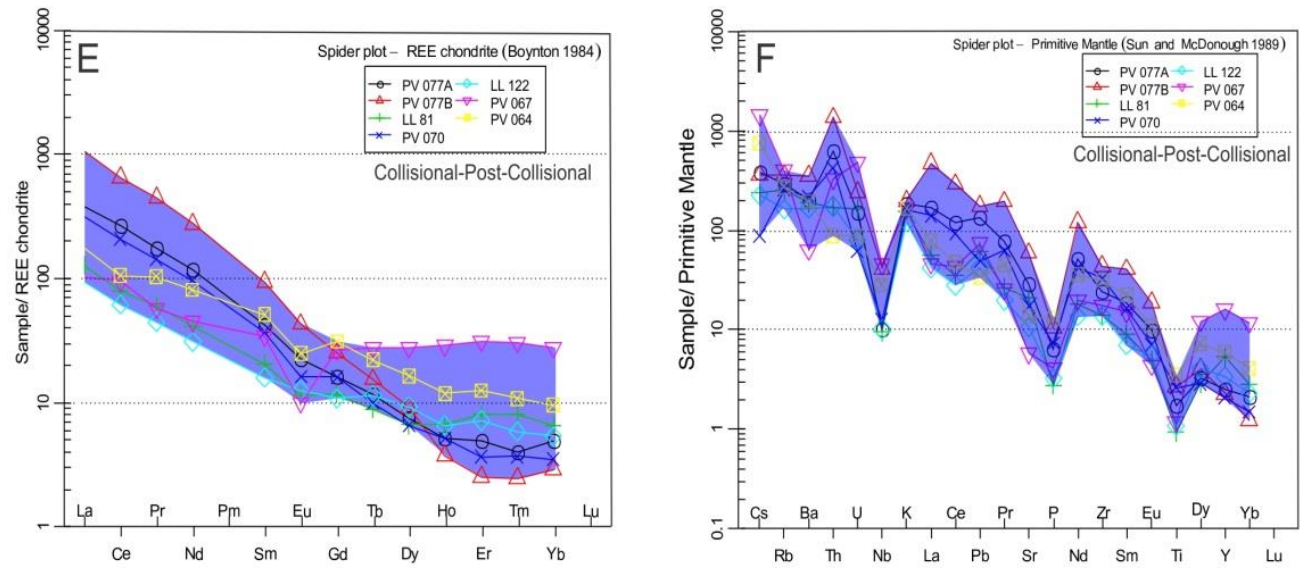

Collisional \& Post-Collisional Continent-Continent

$594+2-578 \pm 6 \mathrm{Ma}$

$545+5 \mathrm{Ma}$
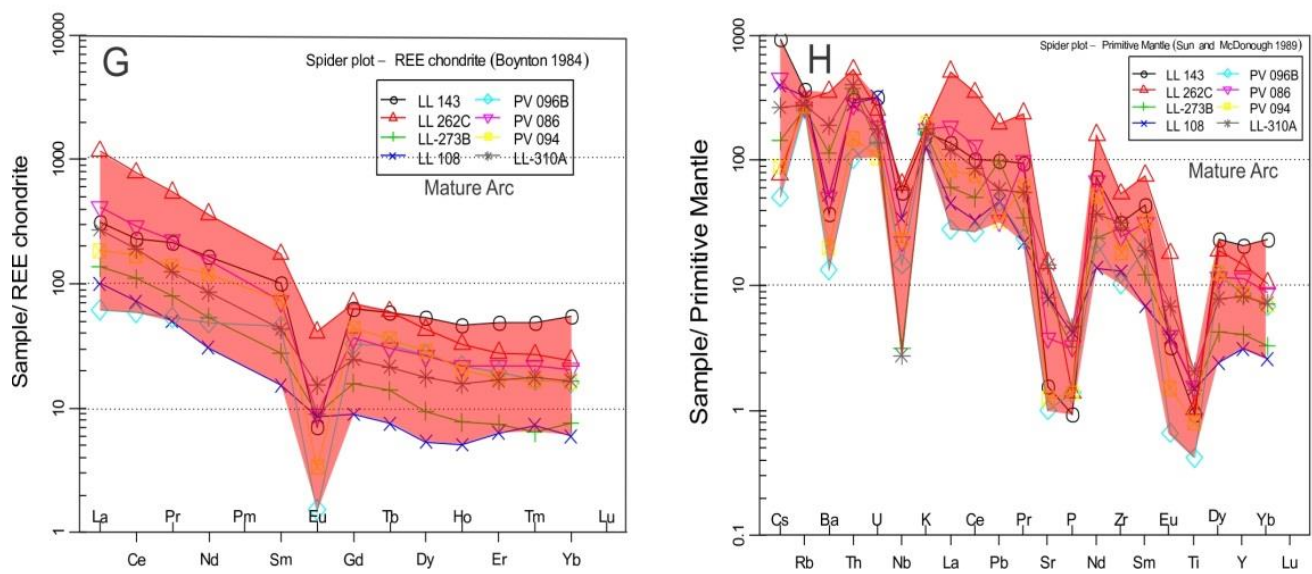

Post-Orogenic

$540 \pm 5-526 \pm 5 \mathrm{Ma}($ Lima, 2007)

Fig. 5.13 - Diagramas ETR normalizados ao condrito de (Boynton, 1984) e spidergramas de Sun e McDonough (1989), para o arco intra-oceânico e arco continental nos estágios propostos. 


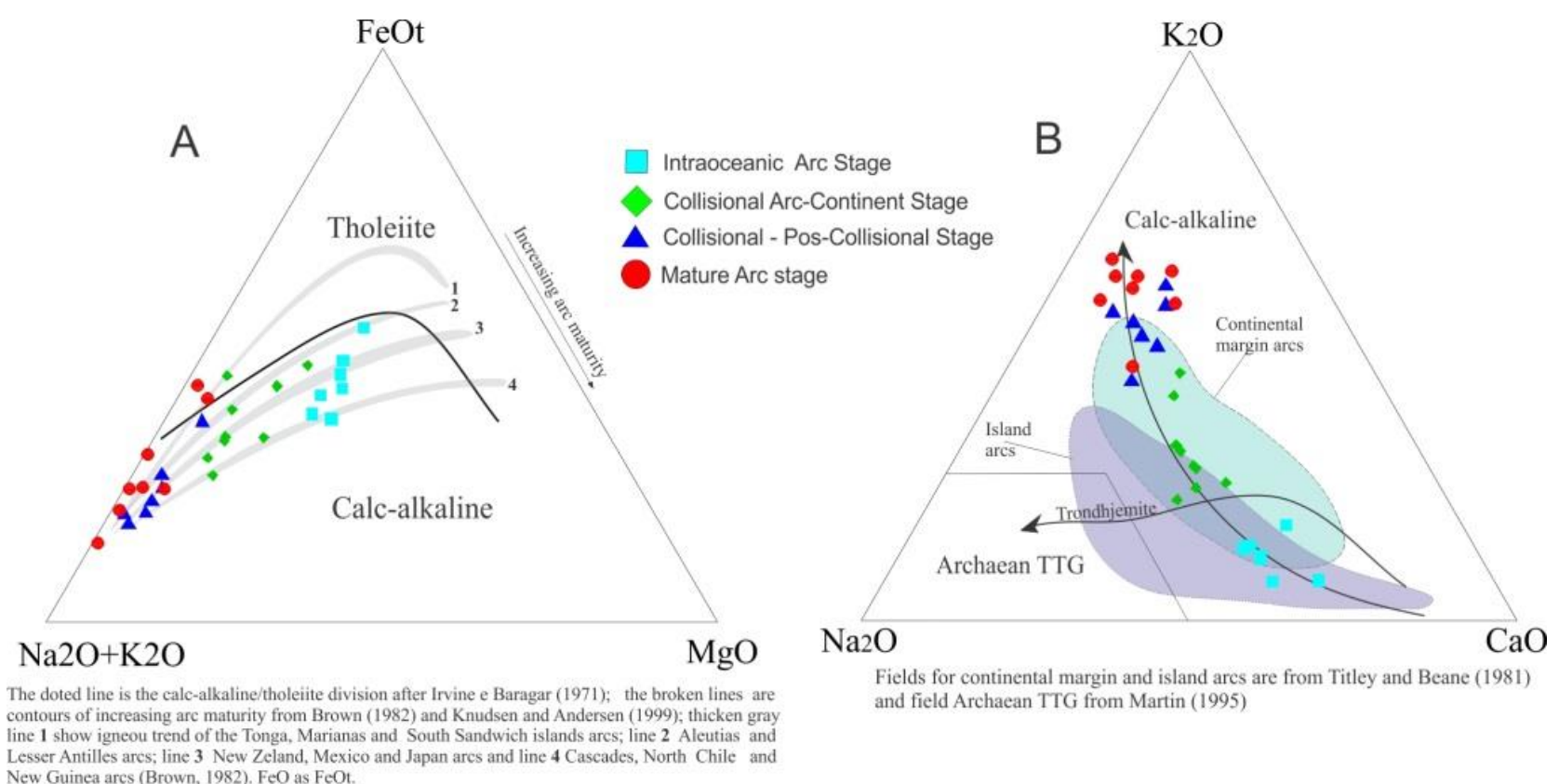

Fig. 5.14 - (A) Diagramas AFM de Irvine e Baragar (1971) modificado por Brown (1982) e (B) diagrama ternário $\mathrm{Na}_{2} \mathrm{O}-\mathrm{K}_{2} \mathrm{O}-\mathrm{CaO}$ (Barker \& Arth, 1976; Titley \& Beane, 1981)
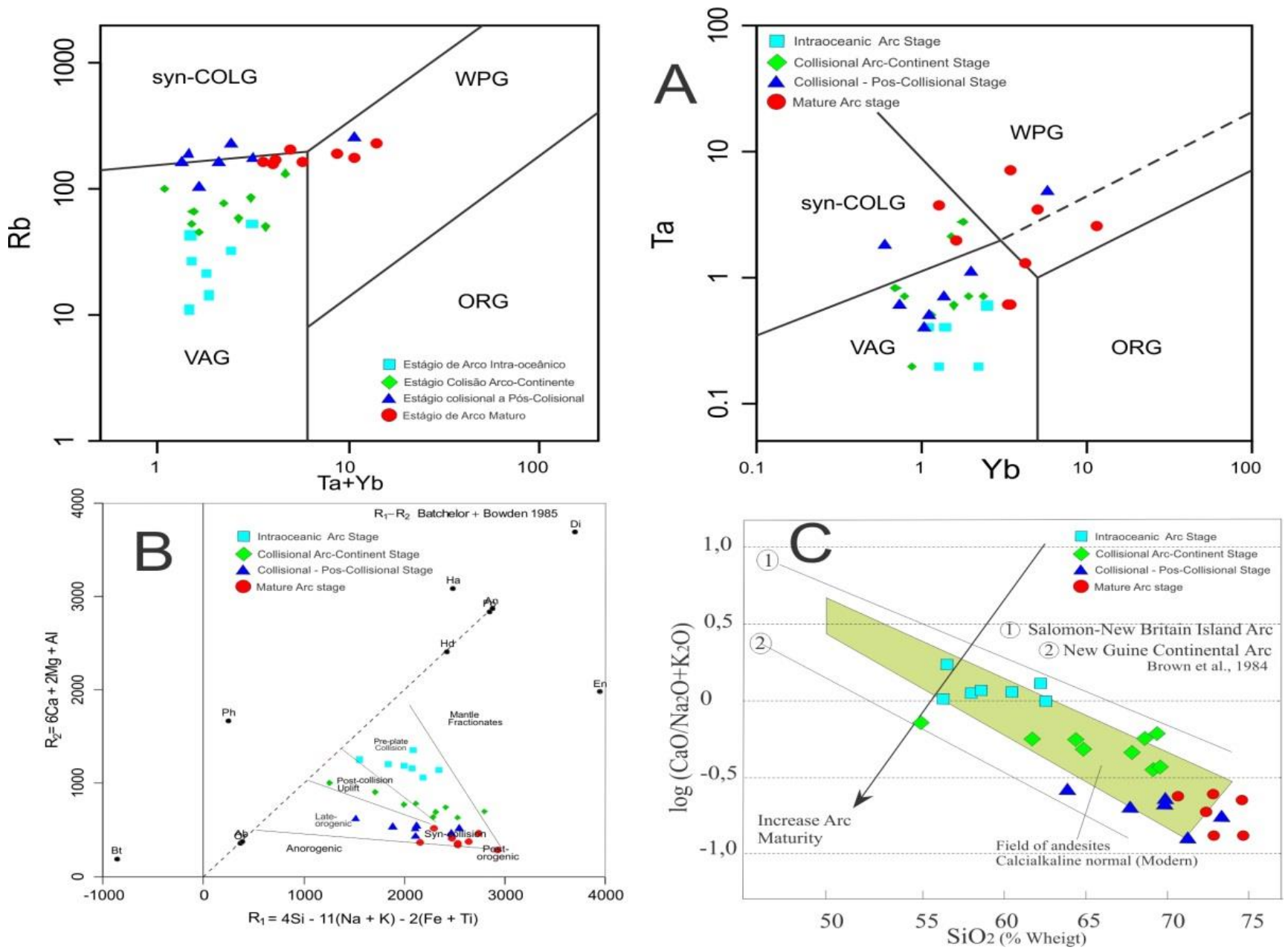

Fig. 5.15 - Gráficos de ambientes tectônicos (A) - (Pearce et al., 1984); (B) - Batchelor e Bowden, 1985; Frost et al., 2001) e (C) diagrama $\mathrm{Na}_{2} \mathrm{O}-\mathrm{K}_{2} \mathrm{O}-\mathrm{CaO} \times \mathrm{SiO}_{2}$, (Frost et al., 2001). 
As rochas possuem padrões químicos semelhantes, conforme tabela 5.1 e 5.2, porém com grupos distintos em idade modelo e extração mantélica, permitindo algumas considerações: (a) distribuição de idades modelo ampla, (b) $12.5 \%$ das amostras apresentam longa residência crustal e de idades arqueanas, $30.21 \%$ tem de idade modelo paleoproterozóica, $37.5 \%$ são de idade mesoproterozóica e 14.6\% neoproterozóicas; (c) magmas de fontes distintas; (d) conforme a diminuição das idades modelo há ingresso de material juvenil e mistura de fontes.

As idades modelo e os diagramas de $\varepsilon_{\mathrm{Nd}}$ estão alocados na tabela 5.3, para os dados obtidos neste trabalho. A fig. 5.16 compõe a distribuição das informações da tabela, acrescidos os dados de $\mathrm{T}_{\mathrm{DM}}$ (Fuck et al., 2001; Fuck et al., 2014). Os diagramas de evolução isotópica de Nd, resultados da tabela 5.3 estão na fig. 5.17, que compara o embasamento com o arco insular e o arco continental. Permite-se em função dos valores de $\mathrm{T}_{\mathrm{DM}}$ e $\varepsilon_{\mathrm{Nd}}$ discriminar áreas de embasamento arqueanomesoproterozóico e áreas ocupadas pelos arcos neoproterozóicos. O embasamento apresenta idades $\mathrm{T}_{\mathrm{DM}}$ variam entre 2980 e 1630 Ma. As idades modelo mais antigas e homogêneas obtidas estão no Bloco Cavalcante-Natividade, onde a maioria do $\mathrm{T}_{\mathrm{DM}}$ é arqueano entre 2.91 e $2.48 \mathrm{Ga}$. No Maciço de Goiás e no embasamento do Orógeno Araguaia as idades modelo são paleo a mesoproterozócas. Os valores de $\varepsilon_{\mathrm{Nd}}$ calculadas para $\left(\mathrm{T}_{2.1}\right)$ apresentam fontes distintas, parte das amostras indicam fontes juvenis e outra parcela mostra evidência de uma crosta antiga e reciclada com valores variando entre $-16.17 \mathrm{a}+3.69$. É comum encontrar lascas do embasamento no interior do LTB e exibem $\mathrm{T}_{\mathrm{DM}}$ variando entre 2540 e $1500 \mathrm{Ma}$.

No arco insular com idades de cristalização entre 848 Ma e 810 Ma o T $\mathrm{DM}_{\mathrm{DM}}$ está entre 1480 e $910 \mathrm{Ma}$, com maior frequência de idades modelo entre 1.1 e $0.9 \mathrm{Ga}$. Todas as amostras apresentam $\varepsilon \mathrm{Nd}_{(\mathrm{T} 840)}$ com valores de $+1.56 \mathrm{a}+5.14$, indicando fontes juvenis.

O estágio de acresção arco-continente exibe distribuição de idades modelo mais extensa, concentrando valores próximos de $1.1 \mathrm{Ga}$. Apresenta características de fontes mistas e heterogêneas, com rochas de derivação crustal e $\mathrm{T}_{\mathrm{DM}}$ indicativa de alta residência crustal, desde $2610 \mathrm{Ma}$, até mais jovens, com $\mathrm{T}_{\mathrm{DM}} 970 \mathrm{Ma}$ e $\varepsilon_{\mathrm{Nd}}$ entre -25.44 a -0.60 , sugerindo a presença de crostas arqueanas a neoproterozóicas recicladas.

Rochas com fontes juvenis possuem idade modelo variável de 1400 Ma a 760 Ma. Apresentam valores de $\varepsilon_{\mathrm{Nd}}$ entre $+0.01 \mathrm{e}+8.01$. As idades $\mathrm{U}-\mathrm{Pb}$ em zircão nestas rochas utilizadas para fins de calculo são ediacarianas. Tanto as rochas com características de fontes juvenis, como as de origem crustal estão misturadas no estágio de acresção arco-continente por motivo tectônico. Da mesma forma, as zonas de cisalhamento do LTB justapõem e retrabalham compartimentos tectônicos diferentes de arco e de embasamento. 
O estágio de acresção colisional a pós colisional apresenta $T_{\mathrm{DM}}$ amplo desde 2370 a $900 \mathrm{Ma}$. A característica principal desde estágio é a fonte fortemente de derivação crustal com valores de $\varepsilon_{\mathrm{Nd}}$ entre -22.42 a -0.3. Apenas duas amostras apresentam neste conjunto fonte juvenil. O estágio final e maturo de arco apresenta idades modelo mais jovens entre 1.4 e $0.82 \mathrm{Ga}$, indicando ainda a presença de reciclagem crustal e interações mantélicas. Granulitos apresentam idade modelo $\mathrm{T}_{\mathrm{DM}}$ de 1,36 Ga com $\varepsilon_{\mathrm{Nd}(\mathrm{T} 580)} \mathrm{de}+0.49$. As rochas associadas a ambiente de arco continental e arco maduro são mais evoluídas quimicamente concordantes com fontes cada vez mais crustais, com idades modelo entre 1,62 e 1,01 Ga e $\varepsilon_{\mathrm{Nd}(\mathrm{T} 580)}$ mais negativos indicando reciclagem das crostas pretéritas.

Rochas máficas gabro anfiboliticas analisadas (TA20 - apêndix I) relacionam-se ao evento tardio pós-colisional e apresentam idade U-Pb 578£6 Ma com herança em 820 Ma. Apresentam idade modelo $\mathrm{T}_{\mathrm{DM}}$ entre $1,49 \mathrm{Ga}$ e 0.82 com $\varepsilon_{\mathrm{Nd}(\mathrm{T} 580)}$ mistos de +4.26 a -1.11 .

Os dados químicos e isotópicos Sm-Nd mostram plena concordância com os períodos de formação e quebra de supercontinentes, desde as acresções ao Supercontinente Columbia e sua fragmentação, a presença de idades associadas ao continente Rodinia e sua quebra e, finalmente, o rearranjo e formação de arcos acrescionários associados à montagem e evolução crustal brasiliana no West Gondwana. 


\begin{tabular}{|c|c|c|c|c|c|c|c|c|}
\hline Sample & LAT & LONG & X_PROJ & Y_PROJ & Sm_ppm & Nd_ppm & 147Sm_144Nd & 143Nd_144Nd_2SE \\
\hline & & & & & Juvenile & 3asement & & \\
\hline HL 186D & -11.5938819 & -48.17677879 & 807901 & 8716828 & 6.853 & 24406.00 & 0.1697 & $0.512376+/-25$ \\
\hline HL $186 \mathrm{C}$ & -11.5938819 & -48.17677879 & 807901 & 8716828 & 2.797 & 12625.00 & 0.1339 & $0.511826+/-19$ \\
\hline HL 113 & -11.02244269 & -48.80446778 & 739885 & 8780660 & 3.29 & 15.26 & 0.1303 & $0,511908+/-16$ \\
\hline LL 275C & -12.34947663 & -48.70497433 & 749569 & 8633732 & 4.000 & 20.934 & 0.1155 & $0.511600+/-16$ \\
\hline LL 278C & -12.0920262 & -48.51211359 & 770815 & 8662038 & 7.471 & 35.344 & 0.1278 & $0.511819+/-22$ \\
\hline LL 278D & -12.0920262 & -48.51211359 & 770815 & 8662038 & 6.040 & 39.092 & 0.0934 & $0.511345+/-12$ \\
\hline |LL 81 & -12.11945393 & -49.41763217 & 672199 & 8659738 & 3.444 & 11.90 & 0.1749 & $0,512467+/-13$ \\
\hline TA 25 & -12.76514832 & -49.60666961 & 651249 & 8588429 & 11.479 & 67.80 & 0.1023 & $0,511471+/-17$ \\
\hline & & & & & Recyclec & Basement & & \\
\hline TA 13 & -12.76563569 & -48.92054204 & 725754 & 8587876 & 8.859 & 64.39 & 0.0832 & $0,511364+/-7$ \\
\hline PV 103 & -12.99074297 & -48.66970316 & 752773 & 8562732 & 0.473 & 0.98 & 0.2911 & $0,512078+/-16$ \\
\hline LL 273D & -12.46930295 & -48.77651643 & 741675 & 8620538 & 12.028 & 66.802 & 0.1088 & $0.511352+/-13$ \\
\hline |LL 114 & -12.9056307 & -49.05993459 & 710499 & 8572504 & 5.824 & 25701.00 & 0.1370 & $0.511812+/-6$ \\
\hline PV 092A & -12.76347435 & -48.92036635 & 725775 & 8588115 & 2.761 & 12.908 & 0.1293 & $0.511661+/-26$ \\
\hline LL 95 & -12.27155151 & -48.85516846 & 733298 & 8642490 & 10.293 & 43.54 & 0.1429 & $0,511862+/-9$ \\
\hline LL 257 & -12.41001732 & -48.00146663 & 826052 & 8626272 & 11.895 & 64.75 & 0.1110 & $0,511330+/-10$ \\
\hline LL $273 \mathrm{C}$ & -12.46930295 & -48.77651643 & 741675 & 8620538 & 3.167 & 21.141 & 0.0905 & $0.510956+/-18$ \\
\hline TA 35 & -12.13448008 & -49.39276485 & 674896 & 8658060 & 3.594 & 23.42 & 0.0928 & $0,510987+/-12$ \\
\hline HL 006 & -11.49494781 & -48.86861777 & 732493 & 8728431 & 5.868 & 36.90 & 0.0961 & $0,510976+/-14$ \\
\hline TA 40 & -11.49539333 & -48.86898096 & 732453 & 8728382 & 2.668 & 14.31 & 0.1127 & $0,511077+/-19$ \\
\hline & & & & & Insular & rc-Stage & & \\
\hline TA 36B & $\begin{array}{l}-12.18044773 \\
\end{array}$ & $\begin{array}{l}-48.98375549 \\
\end{array}$ & 719381 & 8652678 & 44.968 & 200.85 & 0.1353 & $0,512575+/-8$ \\
\hline HL 138 & -11.4706101 & -48.33825595 & 790405 & 8730642 & 4.096 & 22236.00 & 0.1114 & $0.512427+/-14$ \\
\hline LL 119 & -12.91845304 & -48.84189677 & 734154 & 8570896 & 3.107 & 19842.00 & 0.0946 & $0.512291+/-14$ \\
\hline HL 135 & -11.5362515 & -48.3575563 & 788231 & 8723396 & 12.123 & 70578.00 & 0.1038 & $0.512336+/-4$ \\
\hline LL 282A & -12.06173368 & -48.63804994 & 757128 & 8665512 & 12.877 & 73.793 & 0.1055 & $0.512268+/-15$ \\
\hline PV 081B & -14.52272838 & -48.82180794 & 734733 & 8393342 & 2.197 & 9.125 & 0.1455 & $0.51255+/-18$ \\
\hline TA 15 & -12.71326417 & -48.84038524 & 734508 & 8593600 & 2.453 & 10.17 & 0.1459 & $0,512518+/-2$ \\
\hline HL 129 & -11.83625252 & -48.47185486 & 775459 & 8690306 & 16.763 & 80629.00 & 0.1257 & $0.512359+/-6$ \\
\hline LL 143 & -12.55260839 & -48.61701729 & 758937 & 8611168 & 20.810 & 98684.00 & 0.1275 & $0.512355+/-15$ \\
\hline TA 36A & -12.18044773 & -48.98375549 & 719381 & 8652678 & 62.184 & 213.68 & 0.1759 & $0,512670+/-14$ \\
\hline & & & & & Continen & - Arc Stag & & \\
\hline HL 052 & -11.72284838 & -48.08012710 & 818303 & 8702444 & 2.458 & 16.37 & 0.0907 & $0,510933+/-6$ \\
\hline LL 278A & -12.0920262 & -48.51211359 & 770815 & 8662038 & 5.273 & 27.842 & 0.1145 & $0.511519+/-13$ \\
\hline PV070 & -12.41180247 & -48.74928588 & 744690 & 8626876 & 5.244 & 42.386 & 0.0748 & $0.512168+/-24$ \\
\hline PV 70 & -12.41180247 & -48.74928588 & 744690 & 8626876 & 7.988 & 66.80 & 0.0723 & $0,512138+/-5$ \\
\hline PV 080 & -12.70969511 & -48.88870572 & 729262 & 8594038 & 13.098 & 89.448 & 0.0885 & $0.51142+/-11$ \\
\hline LL 123 & -12.9711347 & -49.16915356 & 698593 & 8565344 & 6.120 & 33614 & 0.1101 & $0.512099+/-6$ \\
\hline PV 86 & -12.74737102 & -49.21224890 & 694089 & 8590133 & 16.148 & 103.33 & 0.0945 & $0,512232+/-11$ \\
\hline LL 134B & -12.96887001 & -49.29618207 & 684812 & 8565690 & 3.994 & 19390 & 0.1245 & $0.512549+/-12$ \\
\hline AF 048A & -11.04309318 & -48.58941258 & 763376 & 8778194 & 5.717 & 30.28 & 0.1141 & $0,511976+/-11$ \\
\hline AF 048B & -11.04309318 & -48.58941258 & 763376 & 8778194 & 11.473 & 53.74 & 0.1290 & $0,512061+/-11$ \\
\hline LL 275A & -12.34947663 & -48.70497433 & 749569 & 8633732 & 1.996 & 7.980 & 0.1512 & $0.512141+/-7$ \\
\hline LL 275 & -12.34947663 & -48.70497433 & 749569 & 8633732 & 2.099 & 24.584 & 0.0516 & $0.511908+/-13$ \\
\hline LL 273B & -12.46930295 & -48.77651643 & 741675 & 8620538 & 6.490 & 37.296 & 0.1052 & $0.512103+/-12$ \\
\hline PV 096 & -12.70010496 & -49.09888206 & 706439 & 8595275 & 18.551 & 92.567 & 0.1211 & $0.512314+/-15$ \\
\hline PV 096B & -12.70010496 & -49.09888206 & 706439 & 8595275 & 11.821 & 53.778 & 0.1329 & $0.512396+/-14$ \\
\hline PV $096 \mathrm{C}$ & -12.70010496 & -49.09888206 & 706439 & 8595275 & 10.384 & 49.692 & 0.1263 & $0.5124+/-11$ \\
\hline TA 02 & -12.76567299 & -49.17237503 & 698405 & 8588078 & 10.791 & 55.95 & 0.1166 & $0,512248+/-10$ \\
\hline TA 28 & -12.71182699 & -49.07871573 & 708620 & 8593962 & 11.736 & 54.28 & 0.1307 & $0,512315+/-21$ \\
\hline TA 03 & -12.75286518 & -49.20535925 & 694833 & 8589520 & 2.597 & 19.48 & 0.0806 & $0,512266+/-12$ \\
\hline TA 29 & -12.73603474 & -49.21872787 & 693394 & 8591392 & 32.505 & 223.05 & 0.0881 & $0,512301+/-19$ \\
\hline TA 04 & -12.75011137 & -49.20980787 & 694352 & 8589828 & 13.498 & 79.11 & 0.1031 & $0,512356+/-20$ \\
\hline TA 12 & -12.77123472 & -48.94307368 & 723302 & 8587276 & 3.095 & 19.95 & 0.0938 & $0,511839+/-19$ \\
\hline PV 063B & -12.94449893 & -49.26442437 & 688276 & 8568363 & 11.781 & 92.929 & 0.0766 & $0.511854+/-13$ \\
\hline PV 64 & -12.66635075 & -49.14428274 & 701534 & 8599045 & 9.029 & 41.57 & 0.1313 & $0,512223+/-10$ \\
\hline PV 064 & -12.66635075 & -49.14428274 & 701534 & 8599045 & 2.953 & 37.308 & 0.0478 & $0.512218+/-22$ \\
\hline PV 094 & -14.56543238 & -49.43632338 & 668460 & 8599045 & 13.211 & 63.247 & 0.1263 & $0.512433+/-19$ \\
\hline PV 067 & -12.71220627 & -49.19839018 & 695621 & 8594013 & 7.363 & 31.793 & 0.1400 & $0.512507+/-5$ \\
\hline LL 139 & -12.79813921 & -49.43022890 & 670384 & 8584670 & 2.562 & 8.19 & 0.1892 & $0,512961+/-8$ \\
\hline HL 116 & -11.14937572 & -48.6182356 & 760131 & 8766458 & 5.052 & 33551.00 & 0.0910 & $0.511981+/-7$ \\
\hline LL 108 & -12.27762616 & -49.16917220 & 699127 & 8642070 & 3.318 & 18.85 & 0.1064 & $0,512029+/-12$ \\
\hline & & & & & ranulite syr & ollsional E & & \\
\hline TA 31 & -12.66011471 & -49.27748905 & 6887068 & 8599834 & 1.952 & 7.71 & 0.1530 & $0,512493+/-14$ \\
\hline & & & & e Continen & al Arc-Coll & onal and $\mathrm{P}$ & Collisional st & \\
\hline TA 14 & $\begin{array}{l}-12.76484940 \\
\end{array}$ & -48.91251957 & 726626 & 8587956 & 7.949 & 61.07 & 0.0787 & $0,511349+/-9$ \\
\hline LL 117 & -12.92457279 & -48.97637585 & 719552 & 8570338 & 5.289 & 28472.00 & 0.1123 & $0.511674+/-14$ \\
\hline HL 186A & -11.5938819 & -48.17677879 & 807901 & 8716828 & 1.080 & 4921.00 & 0.1326 & $0.511964+/-64$ \\
\hline HL 186B & -11.5938819 & -48.17677879 & 807901 & 8716828 & 5.213 & 21256.00 & 0.1482 & $0.512041+/-13$ \\
\hline HL 141 & -11.6616858 & -48.1583159 & 809841 & 8709302 & 5.288 & 36438.00 & 0.0877 & $0.511076+/-17$ \\
\hline HL 074 & -11.86184209 & -48.66104204 & 754811 & 8687654 & 2.988 & 8.92 & 0.2026 & $0,512548+/-23$ \\
\hline PV 016A & -12.94449893 & -49.26442437 & 688276 & 8568363 & 13.666 & 68.296 & 0.1210 & $0.512335+/-22$ \\
\hline LL 127 & -12.81072548 & -49.17812043 & 697746 & 8583098 & 15.021 & 90.75 & 0.1001 & $0,512167+/-5$ \\
\hline |LL 127 & -12.81072548 & -49.17812043 & 697746 & 8583098 & 15.444 & 88.129 & 0.1059 & $0.512177+/-7$ \\
\hline LL 282B & -12.06173368 & -48.63804994 & 757128 & 8665512 & 110.558 & 377.960 & 0.1768 & $0.512360+/-9$ \\
\hline HL 033 & -11.36696327 & -48.96598987 & 721967 & 8742668 & 7.209 & 38.02 & 0.1146 & $0,511922+/-6$ \\
\hline TA 46 & -11.89837611 & -48.76459350 & 743492 & 8683704 & 4.525 & 22.71 & 0.1205 & $0,512494+/-14$ \\
\hline TA 08 & -12.53406486 & -48.93316099 & 724586 & 8613510 & 14.849 & 109.96 & 0.0816 & $0,511723+/-21$ \\
\hline PV 077A & -12.68674623 & -48.9215437 & 725715 & 8596606 & 10.240 & 76.735 & 0.0807 & $0.511441+/-6$ \\
\hline PV 077B & -12.68674623 & -48.9215437 & 725715 & 8596606 & 16.236 & 147.441 & 0.0666 & $0.511279+/-9$ \\
\hline TA 18 & -12.46300723 & -48.89761056 & 728513 & 8621342 & 26.423 & 213.92 & 0.0747 & $0,511553+/-21$ \\
\hline LL 273A & -12.46930295 & -48.77651643 & 741675 & 8620538 & 5.126 & 28.642 & 0.1082 & $0.511461+/-15$ \\
\hline LL 134B & -12.96887001 & -49.29618207 & 684812 & 8565690 & 4.87 & 21.34 & 0.1379 & $0,512548+/-20$ \\
\hline & & & & & Post oroge & c mafic roc & & \\
\hline HL 050 & $\begin{array}{l}-11.01244073 \\
\end{array}$ & -48.28957438 & 796188 & 8781306 & 6.986 & 36.48 & 0.1158 & $0,512283+/-22$ \\
\hline PV 087 & -12.7485856 & -49.28787886 & 685875 & 8590054 & 36.224 & 185.366 & 0.1181 & $0.512531+/-18$ \\
\hline HL 035D & -11.09627067 & -48.92015247 & 727183 & 8772582 & 3.048 & 12.39 & 0.1487 & $0,512399+/-27$ \\
\hline TA 20 & -12.55957872 & -49.26048433 & 688989 & 8610944 & 7.698 & 32.79 & 0.1419 & $0,512648+/-7$ \\
\hline
\end{tabular}

Tabela 5.3 - Composição isotópica de Sm-Nd da porção setentrional do Orógeno Brasília, embasamento e Arco Magmático de Goiás (estágios tectônicos) e embasamento do Orógeno Araguaia. 




Tom Distribution

\section{Brasília Orogen}

\section{Goiás Magmatic Arc}

Santa Teresinha de Goiás

Continental Arc and Mature Arc

U-Pb 0.59 - 0.55 Ga

\section{Mara Rosa Arc}

\section{Juvenile Arc}

\section{to U-Pb $0.9-0.8 \mathrm{Ga}$}

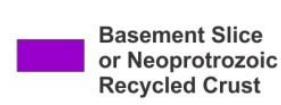

\section{Araguaia Orogen}

Metasedimentary Externaz Zone and some Plutonic Rocks

Orogens Basements - U-Pb $2.1 \mathrm{Ga}$

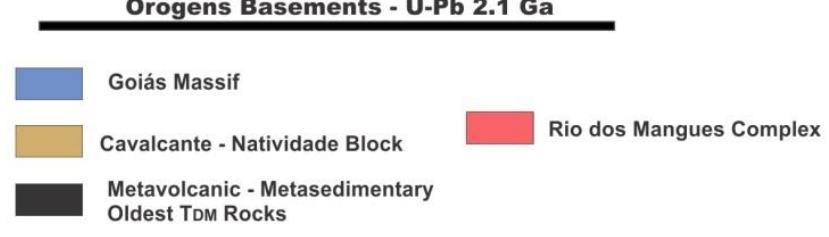

Fig. 5.16 - A distribuiçã̃o das idades modelo. Áreas separadas por padrões $T_{D M}$ distinguem porções de embasamento, arco juvenil e arco continental. Heterogeneidades deformacionais mesclam unidades e demais estágios descritos. $O$ esboço é uma tentativa de estabelecer uma separação de blocos baseada em sua $T_{D M}$, na realidade é uma aproximação tênue da complexidade geológica-estrutural oferecida pelo LTB. 

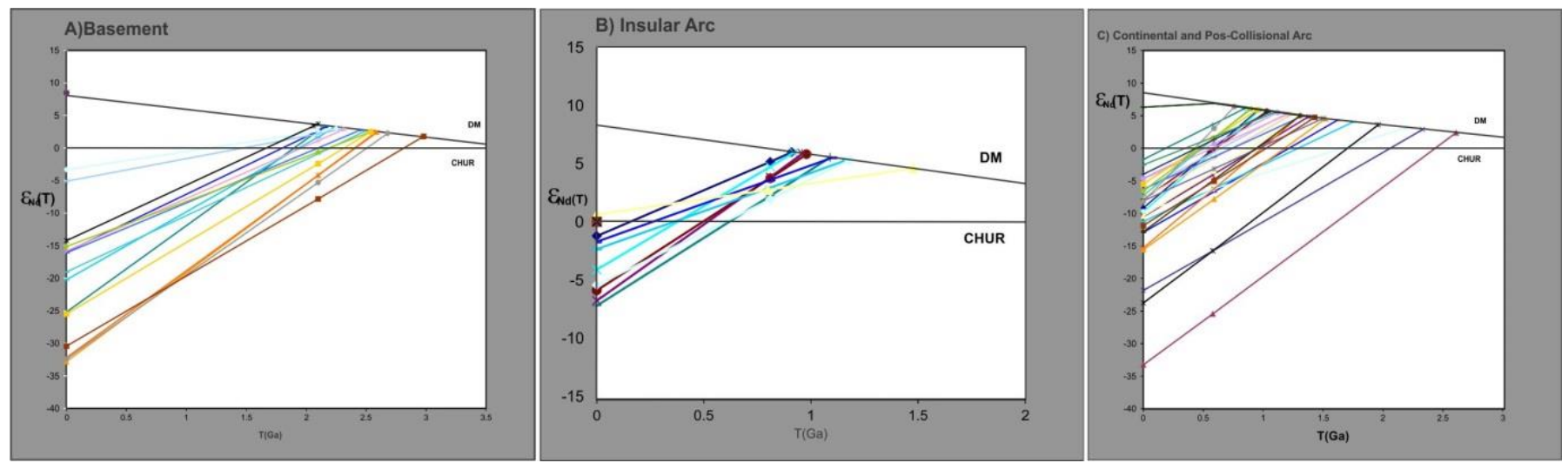

Fig. 5.17 - Diagramas de evolução isotópica de Nd comparando composições isotópicas dos compartimentos A) Embasamento dos orógenos Brasília e Araguaia, b) arco insular juvenil e C) arco continental - pós-colisional do Arco Magmatico de Goiá, parcialmente juvenil/crustal.

\subsection{Discussão}

\subsubsection{Magmatismo de Arco}

O Arco Magmático de Goiás (AMG) é um compartimento geotectônico expressivo do Orógeno Brasília. Coerente com o modelo proposto por Pimentel \& Fuck (1992), representa na área de estudo a extensão setentrional deste segmento por mais $250 \mathrm{~km}$, com cerca de $80 \mathrm{~km}$ de largura. Neste setor do arco se identifica uma característica diferencial, visto que está totalmente incluso no e balizado pelo sistema strike-slip do Lineamento Transbrasiliano. Com o uso integrado de Informações aerogeofísicas, observações de campo, estudos petrográficos, análises geoquímicas, isotópicas e geocronológicas, foi possível individualizar segmentos resultantes de distintas fases de acresção.

Desta forma, foi discriminado um segmento de arco intra-oceânico, que representa a continuidade do Arco de Mara Rosa (Pimentel et al., 2000; Laux et al., 2004; Matteini et al., 2010). Compreende dioritos a granodioritos calci-alcalinos, com idades U-Pb em zircão de $848 \mathrm{Ma}$ e 810 $\mathrm{Ma}, \mathrm{T}_{\mathrm{DM}}$ entre 1480 e $910 \mathrm{Ma}$ e $\varepsilon_{\mathrm{Nd}(\mathrm{T} 840)}$ com valores de $+1.56 \mathrm{a}+5.14$, indicando fontes juvenis. Outro segmento é constituído de rochas mais jovens, formadas em ambiente de arco continental. À semelhança da Sequência Santa Terezinha de Goiás (Fuck et al, 2002, 2006; Junges et al., 2002) inclui os mesmos tipos litológicos, mas com idades mais novas, variando desde $590 \pm 5 \mathrm{Ma}, 568 \pm 9$ Ma até $554 \pm 6 \mathrm{Ma}$ e range de $\mathrm{T}_{\mathrm{DM}} 2610 \mathrm{Ma}$ a $\mathrm{T}_{\mathrm{DM}} 970 \mathrm{Ma}$ e $\varepsilon_{\mathrm{Nd}}$ entre $-25.44 \mathrm{a}-0.60$.

A presença de rochas de idades e fontes comprovadamente diferentes, com características tectônicas, químicas e isotópicas distintas, incluindo rochas transicionais e rochas maduras e tardias, foi demonstrada nos dados. O decréscimo de idades indica que as rochas de arco ediacaranas com- 
põem uma acresção mais jovem, considerada como parte do Arco de Santa Terezinha de Goiás, presente em ambos os lados do LTB no estado de Goiás e como uma porção essencial e centralizada do LTB em Tocantins. As rochas dos distintos eventos encontram-se mescladas ao longo do corredor do lineamento, que contém também faixas estiradas e grandes lascas sigmoidais de embasamento paleoproterozóico.

A comprovação dos dois arcos distintos leva à questão das bacias e crostas oceânicas consumidas nas zonas de subducção, que originaram as rochas tonalíticas a graníticas encontradas nos arcos. Em parte, pode-se inferir que as bacias correspondentes aos arcos ou estão extremamente estiradas ao longo das zonas cisalhamento, preservadas de forma muito restritas, ou não ocorrentes pela exposição de nível crustal profundo encontradas em sua porção a norte.

Pimentel et al., (2000) sugeriram que pequenos corpos ultramáficos reconhecidos no arco Mara Rosa poderiam ser interpretados como remanescentes das bacias oceânicas, separando diferentes arcos, podendo representar antigas zonas de sutura entre sistemas de arcos magmáticos, obliteradas por eventos deformacionais posteriores.

As únicas rochas e unidades pré-Arco de Mara Rosa presentes, além dos inúmeros corpos máfico-ultramáficos mapeados, são as rochas máficas e metassedimentares das sequências Palmeirópolis e Juscelândia, em que pese sua idade em torno de 1,28 Ga a 1,4 Ga (Moraes et. al, 2003). Os dados de idade modelo de várias rochas calci-alcalinas estudadas (Tabela 3) indicam idades de residência crustal concordantes com a idade das rochas vulcânicas básicas dessas sequências, hipótese que, a priori, explicaria a formação do arco intraoceânico. Todavia, incide contra a hipótese da sequência ser a crosta consumida, sua origem e ambientação geotectônica ( Bacia Riftcom magmatismo bi-modal), a posição tectônica e sua interpretação como um segmento alóctone do Maciço de Goiás, posicionando-se em diacronia com o arco insular.

Quanto às rochas máficas oceânicas tipo MORB para o evento mais jovem e gerador das rochas em margem ativa evoluídas de Santa Terezinha de Goiás, os ofiolitos de Quatipuru com idade isocrônica Sm-Nd de 757士 49 Ma Paixão (2008), poderiam muito bem representar os restos da crosta oceânica subductada. As idades de consumo e geração, bem como o posicionamento geotectônico destas assembleias são coerentes e no mínimo simultâneas. Todavia, ocorre outra sugestão para o posicionamento tectônico da unidade Quatipuru. Osborne (2013) propôs para este conjunto ofiolítico do Orógeno Araguaia como uma bacia rift marginal ou uma bacia de back-arc desenvolvida na fronteira oriental do Cráton Amazônico. As datações, das rochas vulcânicas apresentam idades U$\mathrm{Pb}$ em zircão de $634 \pm 21 \mathrm{Ma}$ e $624 \pm 11$ Ma.

A proposta é que uma bacia de back-arc desenvolveu-se a partir da bacia continental com diacrônica extensão e subducção do oceano Goianides sob a margem oriental do Cráton Amazôni- 
co. A inversão da bacia ocorreu durante a Orogenia Brasiliana (Pan-Africano) quando os sedimentos marinhos e sua crosta oceânica foram obduzidos como um conjunto ofiolítico.

Entre as propostas de uma bacia oceânica tipo MORB de Paixão (2008); Paixão et al., (2009) parece estar mais concordante do que uma bacia do tipo back-arc (Osborne, 2013). A proposta de Osborne, (2013) é conflitante, pois não acorda com a posição do arco magmático (margem continental Santa Terezinha de Goiás, 670-630 Ma/ 590-540 Ma), com os dados geofísicos (Soares et al., 2006), além de inverter o sentido da zona de subducção, cuja vergência nesta fase está para leste.

\subsection{2 - Tectônica Strike Slip e Estágios Magmáticos}

A orientação e geometria do LTB e dos arcos magmáticos da Província Tocantins em seu interior encontram-se em relação de paralelismo. Shahabpour (1997), em estudos sobre as relações tectônicas dos componentes de um arco de ilha e tectônica de placas, explana que o arco de curvatura dos arcos intra-oceânicos distais são mais torcidos que os proximais e ainda mais dobrados que os arcos continentais. Expõe também, que quanto maior o ângulo de mergulho da placa, maior a resistência e menor a velocidade de subducção e vice-versa.

Grande parte ou a totalidade dos arcos magmáticos e seus diversos setores foram fortemente deformados e interrompidos pelas zonas de cisalhamento transcorrentes dextrais e zonas de transpressão do Lineamento Transbrasiliano e suas ramificações. Neste sentido e pela geometria exposta é provável que o arco insular tenha acomodado a maior parte da deformação, sendo desfeita sua continuidade física e paralelizado às estruturas do LTB, posicionando-se ao lado ao arco continental mais jovem.

A intensidade da deformação causou deslocamentos importantes nas unidades de arco, abriu espaços e transpôs as relações estruturais e estratigráficas originais. Porções do arco insular foram suprimidas pelas rochas do arco continental. O mesmo ocorre com lascas de embasamento que são reduzidas ao longo das zonas de deslocamento direcional. O produto final das áreas de alto strain é representado por milonitos e ultramilonitos formados por elementos de diversas naturezas, incluindo material de embasamento e supracrustais. Outra evidência da eficácia do processo tectônico é observada na distribuição espacial das idades $\mathrm{T}_{\mathrm{DM}}$ e valores $\varepsilon_{\mathrm{Nd}}$, que se encontra ligeiramente dispersos e de forma heterogênea, em função da justaposição de compartimentos e estágios magmáticos distintos.

\subsection{3 - Zonas de Sutura, Transpressão e Granulitos - O Papel do LTB}


A Orogenia Brasiliana, com consumo crosta oceânica, geração e edificação de arcos, implica na presença de suturas geradas nas colisões margem ativa-arco insular, arco-continente, continentecontinente. Todo o ciclo de Wilson representado pela Província Tocantins, desde a fragmentação de Rodinia ao amálgama de W-Gondwana necessita de suas zonas de sutura.

O melhor candidato é o Lineamento Transbrasiliano, uma megaestrutura de direção principal NE-SW, uma das maiores feições estruturais do planeta, que durante o amálgama de WestGondwana justapôs os orógenos Brasília e Araguaia.

O lineamento é formado por feixes quilométricos de zonas de cisalhamento, falhas transcorrentes com vetor principal dextral, e encerra em seu interior inúmeros blocos crustais de origens e idades diversas. Dados estruturais de campo indicam uma zona central milonítica de transcorrência dextral, com total transposição verticalizada. Os mergulhos são opostos para suas laterais em uma pilha de zonas transpressionais e de nappes epidérmicas, resultantes da convergência oblíqua das paleoplacas delimitadoras, o que lhe confere arquitetura assimétrica e de vergência dupla, semelhante a uma mega"pop up" (fig. 5.18E).

Conforme o modelo da fig. 5.18 (B,C e D) foi necessário o desenvolvimento de zona de intenso encurtamento crustal, de maneira que comprimiu e encaixou em uma área com menos de 100 $\mathrm{km}$ de largura dois arcos magmáticos distintos, fragmentos crustais diversos e lascas de seu embasamento.

A estrutura reflete a disposição das fácies metamórficas de acordo com a distância da zona de transpressão, com rochas de infracrosta e zonas granulíticas no centro. Em direção a ambos os lados da zona, ocorre variação metamórfica gradual para a fácies anfibolito, os ângulos de mergulho ficam menos acentuados, embora ainda altos. A cerca de $40 \mathrm{~km}$ do eixo as vergências ficam radicalmente opostas e tectônica de baixo ângulo predomina, com metamorfismo da fácies xisto verde. A foliação de baixo ângulo é mais suave, tendendo à horizontalidade em direção ao Cráton Amazônico a oeste-noroeste.

Este senso de divergência é registrado na cinemática e deslocamento, onde a lineação de estiramento mineral é transcorrente ao centro e obliqua a frontal para as bordas, acompanhando a disposição das faixas metamórficas e na intensidade deformacional, conforme exposto na (fig. 4.18E). A idade do evento transpressional deve coincidir com a idade proposta para os granulitos em torno de idade de $594 \pm 2$ Ma.

Situação análoga é proposta por Fritz et. al, (2013) no escudo Arábico-Núbio, onde orogenias do leste africano se sucederam de forma análoga e na mesma época. As similaridades de elementos geotectônicos, abrangendo arcos de ilha, margens ativas, embasamento e crátons envolvidos são 
grandes, incluindo zonas de suturas múltiplas que evoluem para zonas de cisalhamento transcontinentais (Fig. 5.18A).

Estudos de refração sísmica profunda (Soares et al., 2006; Ventura et al., 2011) determinaram espessura 36 a 38 km sob o Arco Magmático de Goiás, coincidente com grande anomalia Bouguer positiva ao longo da LTB. A espessura da crosta aumenta até $43 \mathrm{~km}$ no limite do Orógeno Brasília e a borda do Cráton do São Francisco, ao passo que a oeste foi detectada abrupta diferença de espessura, com degrau de $16 \mathrm{~km}$ na passagem do arco para o Orógeno Araguaia e Cráton Amazônico. O abrupto espessamento da crosta foi considerado como o resultado da duplicação da crosta máfica inferior da paleoplaca Amazônica durante subducção abaixo do AMG (Soares et al., 2006). Esta assimetria é de certa forma semelhante à observada nas estruturas em superfície.

Pode-se, então, presumir que o Lineamento Transbrasiliano não representa apenas um sistema transcorrente relacionado com a tectônica de escape lateral na colisão de blocos, como preconizaram Hasui et al. (2012) ou como uma única sutura colisional, como proposto por Cordani et al. (2003), mas que esta feição em algumas de suas zonas represente várias suturas crustais, justapondo compartimentos geotectônicos de evolução e idades diferentes.

Outra característica está em relação à posição do LTB com os arcos, todos em paralelos. Isto implica que apesar do embaralhamento tectônico a geometria como um todo se manteve constante, na ordem embasamento, arco intra-oceânico e arco continental e, portanto as zonas de sutura entre estes diversos segmentos devem estar representados pelas principais zonas de cisalhamento e descontinuidades magnéticas. 


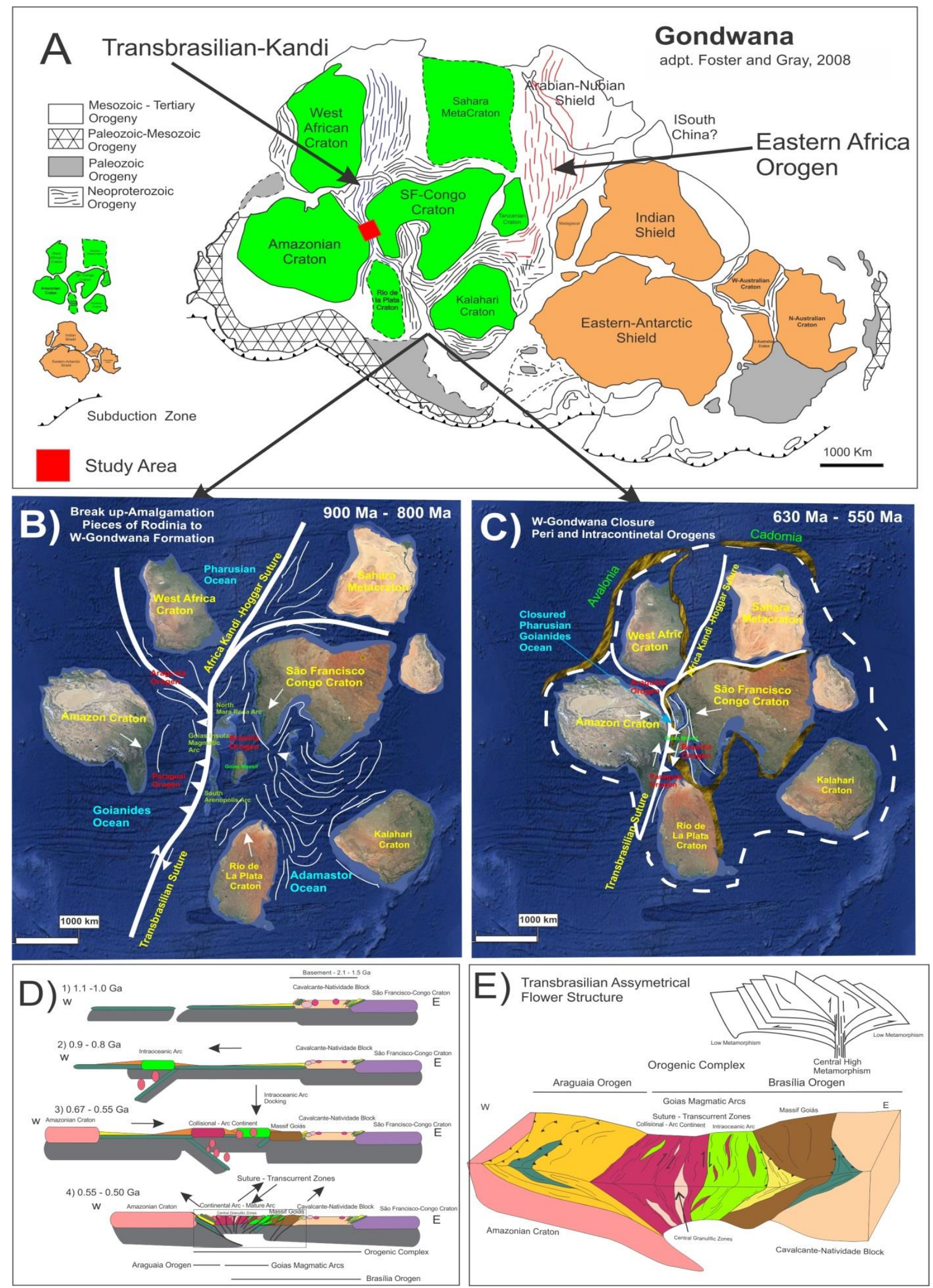

Fig. 5.18- Modelo de evolução geológica para área de estudo dentro do contexto de formação de Gondwana. A) Concepção de Foster and Gray (2008); B e C) Proposta de evolução para W-Gondwana desde período de acresção intraoceânica, arco continental e fechamento. Idades baseadas nos dados de U-Pb e litoquimicos. D) Secção esquemática evolutiva para área. E) Estruturação final e geometria em "pop up" do lineamento Transbrasiliano e arcos coalescidos em um sistema orogênico com acresção transcorrente. 


\subsection{4 - Implicação Global e Regional}

Vários autores esboçaram ideias sobre a quebra do supercontinente Rodinia e a aglutinação de Gondwana e de W-Gondwana. O período de 860-570 Ma é marcado por fenômenos geológicos de natureza distinta, eventos de superplumas e rifteamento continental, que levaram a longo processo de fragmentação de Rodínia. Dados paleomagnéticos para o intervalo de tempo entre $900 \mathrm{Ma} \mathrm{e}$ 830 Ma são escassos. Há pouco registro geológico disponível sobre Rodínia nesse intervalo de tempo. Pequeno número de intrusões em $870-850$ Ma são destacadas, bem como magmatismo bimodal em 845 Ma e 870 Ma, relatados das Caledonides escandinavas (Paulsson e Andreasson, 2002) e de Laurentia (Dalziel e Soper, 2001), ambos interpretados como representando o início do break-up do continente Rodínia. Li et al. (2003) sugeriram que essas intrusões poderiam ter sido o primeiro sinal de uma superpluma. Somam-se neste período as acresções juvenis dos arcos em Goiás entre 860800, tanto em sua região a sul como a norte (Pimentel et al., 1991, 1997; Pimentel e Fuck, 1992; Junges et al., 2002; Laux, 2004; Laux et al., 2004, 2005), introduzindo estes dados à lacuna de idades mundiais.

Após a quebra de Rodinia, uma crosta oceânica se faz necessária para a construção dos primeiros arcos juvenis. Brito Neves et al. (2014) reforçam a ideia, assinalando que os processos da fusão de Rodinia como os de aglutinação de Gondwana constituem um problema em aberto.

Eventos de colisão e deformação iniciado em 820 Ma entre o Cráton São Francisco-Congo e E Gondwana, formando o cinturão Zambeze são citados por Unrug (1992), apontando ainda que imensas zonas de cisalhamento transpressionais e cinturões móveis com magmatismo orogênico foram eventos marcantes que consolidaram a formação do W Gondwana no intervalo 660-500 Ma.

Nesta mesma época, às margens norte e noroeste do continente Gondwana e diacronicamente a seu fechamento, ocorreram às orogenias Avaloniana (cerca de 650-600 Ma) e Cadominiana (cerca de 650-550 Ma), fechando as bacias oceânicas e depressões intracratônicas de Gondwana.

O presente trabalho destaca a quase totalidade desta história registrada em espaço limitado e comprimido e parcialmente preservado em uma das maiores feições estruturais neoproterozóicas, o Lineamento Transbrasiliano. Neste sentido a definição de Complexo Orogênico também se encaixa para caracterizar esta junção dos orógenos Brasília e Araguaia.

Condie (2007) define um complexo orogênico como um segmento que compreende não apenas acresções juvenis, mas também microcratons exóticos, maciços com duração superior a 100 Ma. Estes complexos apresentam componentes juvenis e reciclados que se alternam e mesclam-se no orógeno ao longo de transcorrências, apresentando um amplo range dos valores de $\varepsilon_{\mathrm{Nd}}$, positivos e negativos. Este conceito representa exatamente a área do AMG e LTB em sua porção norte, pois 
Inclui a formação de um arco intra-oceânico de 900 a 800 Ma, sua amálgama, ancoragem a uma crosta paleoproterozóica, superpostas pelo desenvolvimento de uma margem continental ativa, entrada de material juvenil, reciclagem crustal e finalmente colisional, por volta de 590 a $540 \mathrm{Ma}$. Os dados apresentados também prolongam e agrega esta nova perspectiva como um complexo orogênico a qual inclui o Orógeno Brasília e Araguaia em sua conformação à montagem ao W-Gondwana.

Do ponto de vista regional entender os estágios propostos para o arco continental como uma série de acresções contínuas representa estender o período ativo para o Arco de Santa Terezinha de Goiás de 670 Ma a 540 Ma.

Dantas et al., (2007), identificaram este compartimento balizado no LTB e relacionou a evolução dos arcos. Descreveram assinaturas isotópicas juvenis e $\mathrm{T}_{\mathrm{DM}}$ entre 1.5 a $1.2 \mathrm{Ga}$, observando ainda que havia franca participação de material de crosta continental antiga reciclada às rochas juvenis e fornecendo a $\mathrm{T}_{\mathrm{DM}}$ entre 2,6 e 1,7 Ga. Este estágio concorda quimicamente com a classificação proposta neste artigo como estágio colisional a pós-colisional.

Neste trabalho encontraram-se as caracteriticas isotópicas similares ás citadas por Dantas et al., (2007) com fontes mistas e heterogêneas, $\mathrm{T}_{\mathrm{DM}}$ de $2.61 \mathrm{Ga}$ a $0.97 \mathrm{Ga}$ com $\varepsilon_{\mathrm{Nd}}-25.44 \mathrm{a}-0.60$ para as rochas de derivação crustal e para as rochas com fontes juvenis as idades modelo entre $1.4 \mathrm{Ga}$ a $0.7 \mathrm{Ga}$ e $\varepsilon_{\mathrm{Nd}}$ entre +0.01 e +8.01 . O lapso temporal entre $630 \mathrm{Ma} 590 \mathrm{Ma}$, pode ser traduzido apenas como a diminuição da atividade magmática, mas não com seu encerramento. A análise da tabela do anexo I marca a presença de idades em zircão em 637+5 Ma, 620+4 Ma, (AUR12B); 615+7 Ma (TA14) e 604+6 Ma, (TA20). Estas idades, apesar de poucas são fato e não podem ser atribuídas como heranças, uma vez que os desvios padrões médios praticamente se sobrepõem.

\subsection{Conclusão}

O papel da tectônica de placas na Província Tocantins, segmento do W-Gondwana, é evidenciado pela formação de arcos magmáticos acrescionários e também pela natureza e significado geoquímico e isotópico do magmatismo. Os orógenos Brasília e Araguaia correspondem strictu senso a um complexo orogênico neoproterozóico a cambriano, que se estende desde São Paulo ao norte de Tocantins e compreende uma colagem de domínios oceânicos, núcleos e fragmentos continentais e arcos acrescionários de 900 a 540 Ma. O termo complexo orogênico envolve suas distintas acresções, acoplagem de fragmentos crustais e o docking a blocos continentais pré-existentes.

Os dados obtidos para a porção estudada dos orógenos Brasília e Araguaia ao longo da sutura do Lineamento Transbrasiliano confirmam a extensão dos arcos magmáticos de Goiás para a por- 
ção setentrional, conforme já havia sido previsto anteriormente (Pimentel \& Fuck ,1992; Junges et al., 2002; Laux et al., 2005); Dantas et al., 2007; Fuck et al., 2014).

É possível, apesar da intensa deformação, reconhecer seus elementos tectônicos, subdivir os embasamentos dos orógenos Brasília e Araguaia e fases de acresção magmática insular antiga e continental, até a maturidade em eventos progressivos.

Identifica-se o embasamento paleoproterozóico com características litológicas, químicas, idades e fontes em comum, em ambos os lados do LTB, tanto no orógeno Brasília, como no Araguaia. As idades U-Pb em zircão são próximas a $2.1 \mathrm{Ga}, \varepsilon_{\mathrm{Nd}}+3.69$ e +1.11 indicam a presença de rochas juvenis com $\mathrm{T}_{\mathrm{DM}}$ entre 2300 a 2060 Ma e também, um importante evento de retrabalhamento crustal marcado $\varepsilon_{\mathrm{Nd}}-16.17$ e -0.01 com $\mathrm{T}_{\mathrm{DM}}$ entre 2980 a $1950 \mathrm{Ma}$, com idades modelo arqueanas preferenciais ao Bloco Cavalcante-Natividade. O Maciço de Goiás os granulitos do Complexo Porto Nacional e o Complexo Rio dos Mangues na região apresentam similaridades isotópicas e químicas.

É reconhecida no AMG e dentro do LTB uma assembleia petrotectônica que marca acresções com fontes juvenis típicas de arcos de ilhas e relacionadas ao Arco de Mara Rosa, operando entre 900 e 800 Ma. Esta zona hoje é marcada pela junção da Falha Rio dos Bois com o setor oriental do Lineamento Transbrasiliano e sugere uma primeira zona de sutura entre arco e seu embasamento.

$\mathrm{O}$ arco intra-oceânico caracteriza-se por rochas calci-alcalinas intermediária a ácidas, metaluminosas e com valores de $\mathrm{SiO}_{2}$ baixos em torno de $59.67 \%$ e valores de $\mathrm{CaO}$ acima de $6.00 \%$ e de baixos teores em $\mathrm{K}_{2} \mathrm{O}$ de $1.17 \%$, com razões $\mathrm{K}_{2} \mathrm{O} / \mathrm{Na}_{2} \mathrm{O}$ com valores próximos de 0.28 , baixo LILE e HFSE. Apresentam padrões de ETR com baixos a moderados valores em ETRL e depletadas em ETRP com baixo fracionamento, sem dispersão nos valores de ETRP, mostrando uma fonte geradora comum. Idades de cristalização são de 848 Ma e 810 Ma, com $\mathrm{T}_{\mathrm{DM}}$ de 1480 a $910 \mathrm{Ma}$ e ¿Nd $_{(\mathrm{T} 840)}$ com valores de $+1.56 \mathrm{a}+5.14$, indicando fontes juvenis.

Uma segunda fase acrescionária sugere o desenvolvimento inicial de margem continental ativa em 660 Ma, relacionado à evolução de um novo arco, marcado no aumento de fontes mistas, juvenis e crustais. O principal evento na região estudada é de magmatismo ediacarano, que se iniciaram em torno de 590 Ma, estendendo-se até 540 Ma. Forma um arco magmático de margem ativa até sua maturidade. Este arco é entendido como a continuidade e coalescência tectônica do Arco de Santa Terezinha de Goiás situado em posição mais ocidental. A concepção é de que esta fase magmática tardia configure apenas uma parcela evolutiva de um único arco, representando a aglutinação final e fechamento dos orógenos Brasília e Araguaia entre os crátons Amazônico e São Francisco. Esta concepção estenderia a idade do Arco de Santa Terezinha de Goiás até 540 Ma. 
As análises químicas de rochas desde o estágio de arco intra-oceânico até do estágio maduro caracterizam a evolução proposta. Em todos os estágios estão assinalados o progressivo aumento em $\mathrm{SiO}_{2}, \mathrm{~K}_{2} \mathrm{O}$, LILE (Rb, Cs), HFSE ( $\mathrm{Zr}, \mathrm{Y}, \mathrm{Nb}$, Th, U) e ETR. Spidergramas e curvas de ETR marcam rochas com padrões típicos de magmas calci-alcalinos geradas em zonas de subducção com certa contribuição crustal. Estão enriquecidas em LILE e ETRL e depletadas em HFSE e ETRP, com anomalias em $\mathrm{Nb}, \mathrm{P}$, Ti cada vez maiores.

Nos demais estágios arco continente, colisional-pós-colisional e maturo ocorrem um maior espalhamento em relação dos valores ETRP, indicando mais de uma fonte na geração dos magmas com aumento na contribuição de material crustal e diminuição da participação das fontes mantélicas. Observa-se um crescente nos valores de $\mathrm{Pb}$ e Th para as rochas formadas em ambiente de arco continental. Esta adição nestes elementos sugere um aumento da participação sedimentar na zona de subducção e na origem destes magmas. A contribuição e envolvimento de material crustal esta também marcada nos valores de $\varepsilon_{\mathrm{Nd}}$ negativos e na presença de rochas de afinidade peraluminosa.

O estágio arco continente apresenta os isótopos de $\varepsilon_{\mathrm{Nd}}$ e $\mathrm{T}_{\mathrm{DM}}$ compatíveis aos dados químicos. Exibem $\mathrm{T}_{\mathrm{DM}}$ com distribuição ampla e características de fontes mistas e heterogêneas, com rochas de derivação crustal e $\mathrm{T}_{\mathrm{DM}}$ sugestiva de alta residência crustal, de 2610 a $970 \mathrm{Ma}$ e $\varepsilon_{\mathrm{Nd}}$ entre -25.44 a -0.60 , sugerindo a presença de crostas arqueanas a neoproterozóicas recicladas. Rochas com fontes juvenis possuem $\mathrm{T}_{\mathrm{DM}}$ menor e variável de 1400 Ma a $760 \mathrm{Ma}$. Apresentam valores de $\varepsilon_{\mathrm{Nd}}$ entre +0.01 e +8.01 .

O último estágio de acresção colisional a pós colisional apresenta $\mathrm{T}_{\mathrm{DM}}$ amplo desde 2370 a 900 Ma. A característica principal desde estágio é a fonte fortemente de derivação crustal com valores de $\varepsilon_{\mathrm{Nd}}$ entre -22.42 a -0.3

O papel do Lineamento Transbrasiliano (LTB) é fundamental na montagem e desenvolvimento destes arcos. Nos primeiros estágios de sua evolução é responsável pela acresção do arco insular e docking por meio de uma subducção obliqua a uma porção continental. A deformação nesta etapa é principalmente marcada pelo forte encurtamento crustal submetido às rochas do arco intra-oceânico contra a sua plataforma/bloco crustal onde se ancorou, materializada na falha do Rio dos Bois e sua continuidade para norte. Este acomodou grande parte da deformação ao longo desta sutura e dos limites destes terrenos.

Em estagio posterior ao longo da zona de subducção do arco continental e até a fase colisional passou de um sistema obliquo a cada vez mais longitudinal, com a formação de falhas reversas de baixo ângulo as bordas, com escape lateral e ajustando grande parte da deformação ao longo de sua posição meridiana de alto ângulo e transcorrente. 
Nesta fase instalam-se as grandes movimentações de massa, estiramento e embaralhamento tectônico dos compartimentos envolvidos após sua completa acresção. O limite do arco continental mais jovem a oeste coincide com uma lasca de embasamento de idade $2.1 \mathrm{Ga}$, e marca a junção que estabelece os limites das orógenos Araguaia e Brasília.

A porção central dos compartimentos magmáticos fica balizada em campo pelas zonas granulíticas de Porangatu e Porto Nacional, que representam a infracrosta alçada e exumada entre 590 Ma e 540 Ma. Os granulitos marcam uma zona de sutura na parte central do Lineamento Transbrasiliano, realçada por expressivas zonas de cisalhamento e identificada por importantes descontinuidades magnéticas. Os deslocamentos direcionais tardios e de alto ângulo serão os responsáveis por esconder ou mascarar alguns sistemas de falhas iniciais e as zonas de suturas.

O LTB e o AMG em sua porção setentrional se combinam em um segmento estreito. No espaço limitado e inferior a $80 \mathrm{~km}$ de largura dois arcos magmáticos e seu embasamento são encaixados ao longo de uma zona de cisalhamento do tipo strike slip em um modelo de acresção transcorrente.

A evolução de quatro estágios magmáticos pode ainda ser identificada desde toniano até ao final do ediacariano, $\mathrm{O}$ tempo de vida, as características isotópicas e a mistura dos segmentos envolvidos definem este conjunto e o LTB como um complexo orogênico. Neste sentido, o LTB além de assinalar uma das maiores feições estruturais da plataforma sulamericana, uma Zona de Cisalhamento Transcontinental, corresponde também há varias zonas de suturas internas do WGondwana em um modelo tipo “pop up”. Esta peculiaridade deve se prolongar por sob a Bacia do Parnaíba para a Província Borborema, até sua conexão ao continente africano com o lineamento Hoggar-Kandi. 


\title{
Capítulo 6
}

\section{Evidências de Magmatismo Adakítico no Arco Magmático de Goiás, Orógeno Brasília Seten- trional (Brasil), W-Gondwana.}

\author{
A.A.S. Frasca ${ }^{a, b, *}$ E.L. Dantas ${ }^{a}$, R.A.Fuck ${ }^{a}$, J.E. Scandolara ${ }^{c}$ \\ a Instituto de Geociências, Universidade de Brasília, CEP 70910-900 Brasília, DF, Brazil \\ ${ }^{\mathrm{b}}$ Geological Survey of Brazil (CPRM), Setor Marista, 148, CEP 74170-110 Goiânia, GO, Brazil \\ ${ }^{c}$ Geological Survey of Brazil (CPRM), SGAN 603, 1ํA스, CEP 70830-100 Brasília, DF, Brazil
}

\begin{abstract}
Resumo
Na porção setentrional do Orógeno Brasília afloram rochas metamórficas, com protólitos ígneos de composição adakitica. Fazem parte tanto do Arco Magmático de Goiás (Neoproterozóico) quanto intrusivos no embasamento paleoproterozóico da faixa. São tonalitos, granodioritos gnáissicos ou foliados dispostos em vários corpos alongados de dimensões diversas. Dados geocronológicos e geoquímicos distinguem estas rochas em relação às rochas calci-alacalinas adjacentes e indicam sua idade e fonte. Determinações $\mathrm{U}$-Pb em zircão apontam idades de 590-554 Ma. São caracterizados como adakitos tipo $\mathrm{HSA}$ (Alta $\mathrm{SiO}_{2}$ ), alto $\mathrm{Na}_{2} \mathrm{O}>4 \%$, baixas razões $\mathrm{K}_{2} \mathrm{O} / \mathrm{Na}_{2} \mathrm{O}<0.5$, baixo $\mathrm{HFSE}$, alto $\mathrm{Sr}$ (>631 ppm), baixo $\mathrm{MgO} \%$ <1.81 curvas de ETR muito fracionadas, alto ETRL e baixo ETRP, sem anomalias significativas de Eu, baixo $Y<13.6$ ppm, alta razão $\mathrm{Sr} / Y>53.3$ (média), $Y b<1.13 \mathrm{ppm}$, alta razão La/Yb>45.42 e $(\mathrm{La}) n /(Y b) n>30.62$, baixo HFSE. Os adakitos intrusivos no embasamento apresentam $T_{D M}$ de longa residência crustal com idades modelo variando entre 3.38 e $1.75 \mathrm{Ga}$, e assinaturas de $\varepsilon_{N d}\left(T_{0.58}\right)$ entre -31.54 e -6.07. Os adakitos de arco neoproterozóico possuem idades modelo heterogeneas mais jovens entre 0.97 e $0.96 \mathrm{Ma}$ com $\varepsilon_{N d}\left(T_{0.58}\right)$ assinaturas entre -0.60 e -0.95 , indicando participação de material de derivação crustal. A interpretação petrogenética sugere uma fusão primária parcial abaixo de 5\% na base da crosta máfica continental entre o campo rutilo eclogito e anfibolito-hornblenda eclogito com anfibólio-Cpx-granada-plagioclásio no resíduo. Os adakitos mais jovens indicam um contexto pós-colisional produtos de fusão e derivados de delaminação da crosta inferior.
\end{abstract}

Keywords: W-Gondwana - Goiás Magmatic Arc - Adakites - Post-collisional - Delamination

\section{1- Introdução}

Estudos geológicos na porção setentrional do Arco Magmático de Goiás detectaram rochas com os sinais litoquímicos de adakitos. Em geral, são rochas tonalíticas de composição ácida que apresentam assinaturas químicas com altas concentrações de $\mathrm{Na}_{2} \mathrm{O}$ (>3.5\% em peso), alto $\mathrm{Sr}, \mathrm{La}$, altas razões $\mathrm{Sr} / \mathrm{Y}$, forte fracionamento de ETR com depleções em ETRP e altas razões La/Yb.

Adakitos foram originalmente reconhecidos no arco de ilhas das Aleutas, onde são associados com zonas de subducção jovens (@25 Ma, Drummond e Defant, 1990). Em comparação com andesitos, dacitos e riolitos, calcialcalinos de arcos insulares, os adakitos têm altas concentrações de $\mathrm{Na}_{2} \mathrm{O}(>3.5 \%$ e $<7.5 \%), \mathrm{Sr}(>400 \mathrm{ppm})$, baixo teores de $\mathrm{MgO}(<3 \%)$, razão $\mathrm{K}_{2} \mathrm{O} / \mathrm{Na}_{2} \mathrm{O}(\sim 0.42)$, baixas concentrações de $\mathrm{Y}(<18 \mathrm{ppm})$ e $\mathrm{Yb}(<1.8 \mathrm{ppm})$, depleção em elementos ETRP e altas razões $\mathrm{Sr} / \mathrm{Y}$ e razões La/Yb altamente fracionados (Drummond e Defant, 1990; Defant e Drummond, 1993, Martin et al., 2004). 
Além destas características foram identificados dois grupos distintos de adakitos, que são distinguidos com base em seu conteúdo de sílica Martin et al. (2005) e Martin e Moyen (2003): uma de alta $\mathrm{SiO}_{2}$ (HSA, $\mathrm{SiO} 2>60 \%$, em peso), que se considera estas rochas como produto de fusão de uma crosta oceânica em zonas de subducção e reação com a cunha do manto peridotítico e uma segunda composta por um grupo de adakitos de baixa $\mathrm{SiO}_{2}$ (LSA) interpretados como produtos da fusão de um manto peridotítico, cuja composição foi modificada por reação com magmas e fluidos félsicos da placa (metassomatismo) Na maioria das definições são combinados critérios composicionais, onde os componentes químicos da rocha são determinantes para sua classificação ligada a uma interpretação genética para a ocorrência (Castillo, 2006).

A geração de magmas resultantes de reações de fusão de basaltos hidratados tem suporte em vários estudos (Defant e Drummond, 1990; Sajona et al., 1993; Peacock et al., 1994; Martin, 1999; Qu et al., 2004; Martin et al., 2005; Zhu et al., 2008). As propostas de modelos geodinâmicos, todos relacionados à subducção, incluem: (a) subducção de crostas oceânicas jovens e quentes; $(b)$ geração de magmas adakíticos no início do processo de subducção; $(c)$ subducção rasa; $(d)$ subducção rasa e obliqua.

Ao mesmo tempo, uma corrente de pesquisa diversa propõe a existência de rochas adakiticas com características químicas semelhantes e não diretamente relacionadas a fusão da placa oceânica em zonas de subducção (Atherton \&Petford, 1993; Barnes et al., 1996; Gao et al., 2004; Wang et al., 2004; Guo et al., 2006; Castillo, 2006; Xu et al., 2006; Wang et al., 2006; Hou et al., 2007; Huang et al., 2008; Omrani et al. 2008; Liu et al., 2008; Zhao \& Zhou, 2008). Consequentemente diferentes processos geodinâmicos foram inferidos: (a) colisão arco-arco; (b) "ridge subducction”; (c) janelas de placa (slab window) ou fusão parcial de crostas delaminadas; $(d)$ "slab tearing following ridge-trench collision"; $(f)$ colisão continental.

Outros estudos têm mostrado que as rochas adakiticas e um número de adakitos previamente relatados na bibliogtafia são produzidos por fusão da crosta máfica inferior ou em câmara magmática basáltica represada na base da crosta, processos de misturas de magmas sob alta ou baixa pressão e fracionamento mineral, tanto em ambiente de arcos, como em sistemas não relacionados a arcos (Castillo, 2006).

Apesar da ocorrência de vários arcos neoproterozóicos, as rochas de natureza adakíticas têm sido raramente descritas na literatura geológica no Brasil, ou pelo menos, o uso do termo adakito é restrito. Na província Tocantins, Pimentel et al., (1997), citaram rochas tonaliticas e andesíticas com similaridades químicas e isotópicas de adakitos no Arco Magmático de Goiás, especificamente na porção setentrional do Arco de Mara Rosa, ao sul da área de estudo. 
A fragmentação do continente Rodínia remontou a configuração de blocos continentais e resultou na criação de um oceano denominado Goianides-Pharusian (Kröner \& Cordani, 2003; Cordani et al., 2013) localizado entre os crátons Amazônico e São Francisco-Congo. A partir de 1.0 Ga a placa oceânica formada entra em subducção, criando há cerca de 900-800 Ma um arco intraoceânico juvenil, o Arco de Mara Rosa, (Pimentel et al., 2000). Durante o Criogeniano o arco insular conectou-se às margens de uma plataforma continental paleo-mesoproterozóica. Ao longo da borda deste microcontinente e do arco insular, entre 670-630 Ma desenvolveu-se uma margem continental ativa (Arco de Santa Terezinha de Goiás) (Fuck et al., 2002; Junges et al., 2002). Estes arcos formam um o compartimento tectônico denominado Arco Magmático de Goiás (Pimentel \& Fuck, 1992; Pimentel et al., 1997, 1998, 2000), pertencente ao Orógeno Brasília. Conforme os crátons Amazônico e São Francisco-Congo se aproximavam houve o fechamento do orógeno Brasília com pico metamórfico regional, em sua porção central por volta de 650-630 Ma, registrado em rochas granulíticas (Piuzana et al., 2003; Della Giustina et al., 2009). Na porção setentrional do orógeno Brasília o magmatismo colisional e pós-colisional prossegue de 595-550 Ma. A contínua colagem de arcos e microcontinentes formou um novo bloco continental, o West Gondwana, precursor de Pangea.

Além do Arco Magmático de Goiás, outros arcos acrescionários se instalaram em torno e internamente ao West Gondwana, como o orógeno São Gabriel de 840-750 Ma, (Lena, 2013), o arco juvenil Rio Negro do Orógeno Ribeira com $\varepsilon N d(t)$ de -3 a +5 e idade 790-600 Ma, (Tupinambá et al, 2012) e os arcos insulares no Escudo Arábico-Nubiano (ANS) de idades 804 Ma e $\varepsilon N d$ positivos (Zakariadze et al., 2007), como colagens ao East-Gondwana.

O objetivo deste trabalho é apresentar algumas evidências litoquímicas e discutir a presença dos tipos adakíticos encontrados na porção setentrional do Arco Magmático de Goiás. Dados geocronológicos U-Pb e isótopos de Sm-Nd são apresentados para complementar as considerações sobre processos geodinâmicos, petrogenéticos e implicações decorrentes sobre a ocorrência destas rochas no Orógeno Brasília e evolução do West Gondwana nesta região.

\section{2 - Estruturação Geológica}

O Orógeno Brasília é uma faixa neoproterozóica, integrante da Província Tocantins, a qual ainda inclui os orógenos Araguaia e Paraguai (Almeida, 1967, 1968; Hasui \& Almeida, 1970; Almeida et al., 1976, 1977, 1981). A província, posicionada no Brasil central, desenvolveu-se durante a amálgama do paleocontinente W-Gondwana, como consequência da colisão entre os crátons Amazônico, São Francisco-Congo e Paranapanema. Em comum, as faixas apresentam diacronismo 
na evolução e um conjunto de unidades supracrustais empurradas de encontro à borda de seus crátons adjacentes, com padrões deformacionais e metamórficos progressivamente diminuindo em direção às áreas estáveis. Das três faixas apenas o Orógeno Brasília inclui um sistema de arcos magmáticos preservados.

\subsubsection{O Orógeno Brasilia}

A compartimentação do Orógeno Brasília é entendida com base nos trabalhos de Fuck et al., (1993, 1994); Pimentel et al., (2000, 2004), Dardenne (2000) e Lacerda Filho et al. (1999) e Delgado et al., (2003). A fig. 6.1 exemplifica uma parcela desta composição e sua adjacência ao Orógeno Araguaia. A ênfase é dada às áreas de estudo, (retângulos vermelhos) na porção setentrional da faixa. Neste corte Fuck et al., (2014), descrevem a seguinte divisão para o Orógeno Brasília: (i) embasamento arqueano -paleoproterozóico com terrenos granito-gnáissicos e sequências vulcanossedimentares denominado Bloco Cavalcante-Natividade; (ii) extensão do Maciço de Goiás (Pimentel et al., 2004) incluindo os complexos máfico-ultramáficos acamadados (Barro Alto, Niquelândia e Cana Brava) e seqüências vulcanossedimentares associadas (Sequências de Juscelândia, Indaianópolis e Palmeirópolis e (iii) extensa área de terrenos ortognáissicos e faixas vulcanossedimentares de idade neoproterozóica, com fontes juvenis e crustais, representando terrenos do Arco Magmático de Goiás (AMG), os arcos magmáticos Mara Rosa e Santa Terezinha de Goiás, (Pimentel et al., 2000; Laux et al., 2004; Junges et al., 2002; Fuck et al., 2002).

Bloco Cavalcante-Natividade representa o embasamento mais antigo, Fuck et al., (2014) compreendendo: a) ortognaisses com idades entre 2.3 e 2.4 Ma e idades modelo $\mathrm{T}_{\mathrm{DM}}$ mais antigas que 2,5 Ga, sugerindo reciclagem de material crustal envolvido na construção da crosta paleoproterozóica; $b$ ) um evento magmático entre 2,2 e 2,15 Ga, constituido por granitóides peraluminosos e ortognaisses da Suíte Aurumina (Botelho et al., 2006) sugerindo reciclagem de crosta mais antiga, como inferido a partir de valores negativos de $\varepsilon_{\mathrm{Nd}} ; c$ ) magmatismo peraluminoso tardio (ca. 2,0 Ga), cuja extensão e significado não são ainda bem compreendidos. A partir de 1,77 Ga segue-se o vulcanismo bimodal basal e depósitos sedimentares em ambiente tipo rift continental dos grupos Araí e Natividade que cobrem os gnaisses paleoproterozóicos, (Pimentel et al., 1991; Pimentel e Botelho, (2001). 


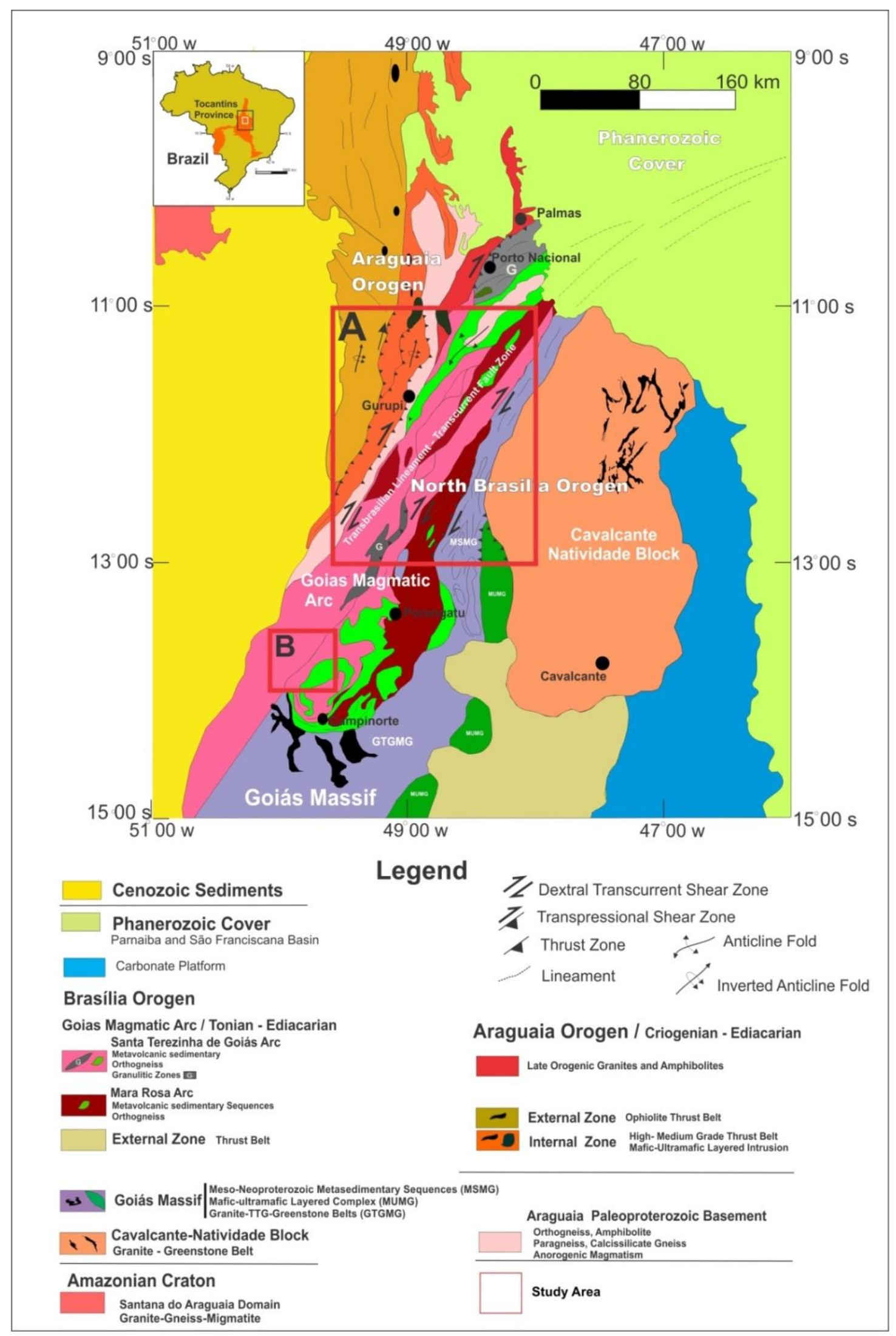

Fig. 6.1 - Contexto geológico regional da Província Tocantins. Segmento setentrional do Orógeno Brasília e Araguaia. Retângulos vermelhos representam áreas de estudo onde ocorrem rochas adakiticas. Composição regional adaptada de (Hasui et al., 1977; Fuck et al., 2014, Frasca et.al, 2015). 
O Maciço de Goiás representa o embasamento mais jovem, está entre o Bloco CavalcanteNatividade e os arcos neoproterozóicos, espremido em uma faixa transpressional associada ao lineamento Transbrasiliano (LTB). Este domínio abrange granitos e granodiorito-gnaisses, recobertos por rochas metassedimentares proterozóicas do Grupo Serra da Mesa. Na área de estudo englobam também a seqüência vulcanossedimentar Mesoproterozóica Palmeirópolis. Fuck et al., (2014), apresentam resultados isotópicos que indicam idades modelo TDM variando entre 2,04 e 2,85 Ga, e $\varepsilon N d$ (T) valores entre 2 e -7. Esta dispersão de valores $\varepsilon N d$ positivos e negativos sugere tanto uma componente juvenil na formação de crosta continental como também indicam retrabalhamento da crosta continental Arqueana. Idade U-Pb em zircão é de $2143 \pm 11$ Ma e concordia de $2022 \pm 14$ Ma, que são interpretadas como a idade de cristalização dos protólitos graniticos ígneos.

$\mathrm{Na}$ parte oeste do maciço em rochas ortoderivadas foram obtidas idades $\mathrm{U}-\mathrm{Pb}$ em zircão semelhantes de $2142+11$ e $2083+18 \mathrm{Ma}$, com $\mathrm{T}_{\mathrm{DM}}$ entre $2460 \mathrm{Ma}$ a $2370 \mathrm{Ma}$, e $\varepsilon_{\mathrm{Nd}}(2.1 \mathrm{Ga})$ negativos entre -0.23 e -16,28, sugerindo retrabalhamento e derivação crustal (Frasca et.al, 2015). Alguns poucos $\varepsilon \mathrm{Nd}$ positivos na ordem de +2.83 e +2.51 são encontrados no embasamento nos limites dos orógenos Brasília e Araguaia, evidenciando pequena, mas importante comprovação de contribuição juvenil.

O Arco Magmático de Goiás (Pimentel \& Fuck, 1992; Pimentel et al., 1996, 1998, 2000; (Fuck et al., 2002, 2006; Junges et al., 2002; Laux et al., 2005) ocupa a porção ocidental da Orógeno Brasília e também da área de estudo. Representa o registro do consumo e fechamento do domínio oceânico Goianides-Pharusian (Kröner \& Cordani, 2003; Cordani et al., 2013) entre os crátons Amazônico e São Francisco-Congo.

A figura 6.2 mostra a porção setentrional do Arco Magmático de Goiás e sua compartimentação nas áreas de estudo e a figura. 6.3 é um esboço geológico de uma folha 1:100.000 localizada $100 \mathrm{Km}$ a sudoeste. Os corpos adakiticos encontrados estão representados em vermelho. A fase précolisional compreende um arco de ilha juvenil de idade 900-800 Ma, chamado de Mara Rosa, caracterizado por mostrar rochas com afinidades tholeíitica e calci-alcalina com razões isotópicas ${ }^{87} \mathrm{Sr} /{ }^{86} \mathrm{Sr}$ iniciais baixas e valores $\varepsilon \mathrm{Nd}$ positivos, com idade modelo $\mathrm{T}_{\mathrm{DM}}$ principalmente entre $0,8 \mathrm{e}$ 1,1 Ga (Pimentel \& Fuck, 1992; Laux et al., 2005). Mais a norte Frasca et.al, (2015), reconhecem os fragmentos deste arco de ilha, correspondente a tholeiitos de arco e tonalitos e granodioritos gnaisses rompidos em faixas e zonas miloniticas e internas ao Lineamento Transbrasiliano (LTB). Suas rochas de composição intermediária a ácida são calci-alcalinas, depletadas em LILE e HFSE,


com valores de $+1.56 \mathrm{a}+5.14$, confirmando as fontes juvenis. 
Por volta de 670-630 Ma, um arco continental mais jovem nomeado de Santa Terezinha de Goiás (Fuck et al., 2002, 2006; Junges et al., 2002), com sequências vulcanossedimentares estendese tanto ao sul como a norte lateralmente ao Arco Insular de Mara Rosa. Constitui-se de rochas supracrustais e plutônicas de arco, incluindo tonalitos, granodioritos, gabros, dioritos e granitos muito deformados e gnaissificados. Idades U-Pb em zircão obtidas nessas rochas variam entre 640 e 620 Ma. Apresentam valores $\varepsilon_{\mathrm{Nd}}(\mathrm{T})$ entre $+2,8$ e $-15,1$, sendo a maioria das rochas com $\varepsilon_{\mathrm{Nd}}$ negativo, levando os autores a concluir pela provável formação em margem continental ativa no final da orogenia Brasiliana e pelo envolvimento de crosta continental mais antiga.

O arco foi envolvido na colisão e tem seu principal evento magmático contemporâneo a ela. Dados indicam que o principal evento de subducção terminou em 630-600 Ma, e que o principal pico metamórfico regional, ocorreu por volta de 650-630 Ma, conforme registrado em rochas granulíticas (Piuzana et al., 2003; Della Giustina et al., 2009).

Contudo, na porção setentrional do Orógeno Brasília o arco continental mais jovem de idade 670-630 Ma e um compartimento mais recente com idades U-Pb em zircão em torno de 590 a 550 Ma, intrudem e reciclam as unidades mais antigas, Dantas et al.,(2007). Frasca et.al, (2015) compartimentaram este arco em três estágios. Compreende um estágio colisional arco-continente com rochas tonalíticas a granodioríticas que apresenta LILE médios a elevados, HFSE baixos a moderados, enriquecimento em ETRL e depleção em ETRP sem anomalia de Eu, possuem fontes mistas, parte de derivação crustal, parte juvenis com $\mathrm{T}_{\mathrm{DM}}$ em torno de $1235 \mathrm{Ma}$ e $\varepsilon N d$ de $-6.69 \mathrm{a}+6.13$.

O estágio colisional seguinte representa a maturidade química do arco. Possui valores elevados LILE e HFSE com anomalias positivas em Th, La, K e Zr e padrões negativos em $\mathrm{Ba}, \mathrm{Nb}, \mathrm{P}$ e Ti pronunciados, padrões assimétricos e enriquecidos em ETRL, depletados em ETRP com anoma-

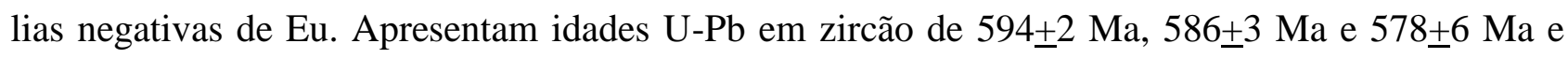
grãos zircão herdados do arco insular com idades $822 \pm 15 \mathrm{Ma}, 884 \pm 11 \mathrm{Ma}$ e $855 \mathrm{Ma}$, $\mathrm{T}_{\mathrm{DM}}$ entre 1620 e $1010 \mathrm{Ma}$ e $\varepsilon_{\mathrm{Nd}(\mathrm{T} 580)}$ de -0.3 a -12.9. Neste estagio foi identificado geração de magmas calcialcalinos em ambiente de arco magmático colisional a pós-colisional e rochas com afinidades adakíticas. Nas rochas com similaridade a adakitos encontradas, realizou-se um estudo sistemático de geoquimica convencional e isotópica, além de datação U-Pb para caracterizar idade e fonte geradora do magma.

O estágio de arco maduro apresenta padrões comuns no arco continental pós-colisional. Há maior enriquecimento em HFSE do que em LILE, todos com valores muito elevados. Os REE seguem o comportamento dos demais elementos traço, ETRL e ETR elevados com anomalias negativas de Eu. As idades de cristalização são próximas a 545 Ma. Rochas básicas pós-orogênicas anali- 
sadas apresentam fontes crustais e juvenis e $\mathrm{T}_{\mathrm{DM}}$ entre 1490 e $820 \mathrm{Ma}$, com $\varepsilon_{\mathrm{Nd}(\mathrm{T} 530)}$.de -1.41 a +3.91 .

Todas as caracteristicas descritas acima sugerem que o AMG represente um complexo orogenico no sentido de Condie (2007), que define um complexo orogênico como um segmento que compreende não apenas acresções juvenis, mas componentes juvenis e reciclados que se alternam e mesclam-se em um orógeno ao longo de transcorrências, apresentando um ampla variação de idades modelo e de valores de $\varepsilon \mathrm{Nd}$, positivos e negativos. O tempo de formação desses complexos deve ser superior a $100 \mathrm{Ma}$, e é frequente a associação de microcratons exóticos, maciços e embasamentos diversos.

Frasca et al., (2015) englobaram este conceito para representar a área do AMG e LTB em sua porção norte, pois inclui todos estes elementos desde a formação de um arco intra-oceânico de 900 a 800 Ma, sua amálgama, ancoragem a uma crosta paleoproterozóica, superpostos pelo desenvolvimento de uma margem continental ativa, entrada de material juvenil, reciclagem crustal culminando com evento colisional. Todo processo teria por volta de 590 a 550 Ma de duração, incluindo 100 Ma para arco intraoceânico e 120 Ma para o período de acresção continental, com períodos de quiescência magmática, desde a quebra de Rodínia à montagem de W-Gondwana.

\section{3 - Ocorrência e Petrografia}

As rochas de tendência adakítica do AMG ocupam posição central no LTB (fig. 6.2 e 6.3), Formam corpos estreitos, alongados, pouco volumosos e alojados às zonas de cisalhamento transcorrentes e transpressionais. Distribuem-se desde a porção norte no limite com o Orógeno Araguaia e se estendem para sul por dezenas de quilômetros. Outras ocorrências não mapeáveis ocorrem no embasamento do orógeno Brasília, ao longo do Maciço de Goiás nas adjacências do arco magmático neoproterozóico.

Geralmente, associam-se ou estão próximos às zonas de grau metamórfico elevado. São rochas plutônicas leucocráticas, constituídas principalmente por tonalitos, granodioritos com hornblenda e biotita, monzogranitos e quartzo dioritos subordinados. Apresentam texturas porfiríticas e blastoporfiríticas, resultado de sobreposição metamórfica de fácies anfibolito a xistos verdes alto, com a formação de texturas granoblásticas e nematoblásticas. Recristalização total e parcial, com poligonização, junções tríplices de alta temperatura, estruturas gnáissicas e miloníticas são comuns nestas rochas. 


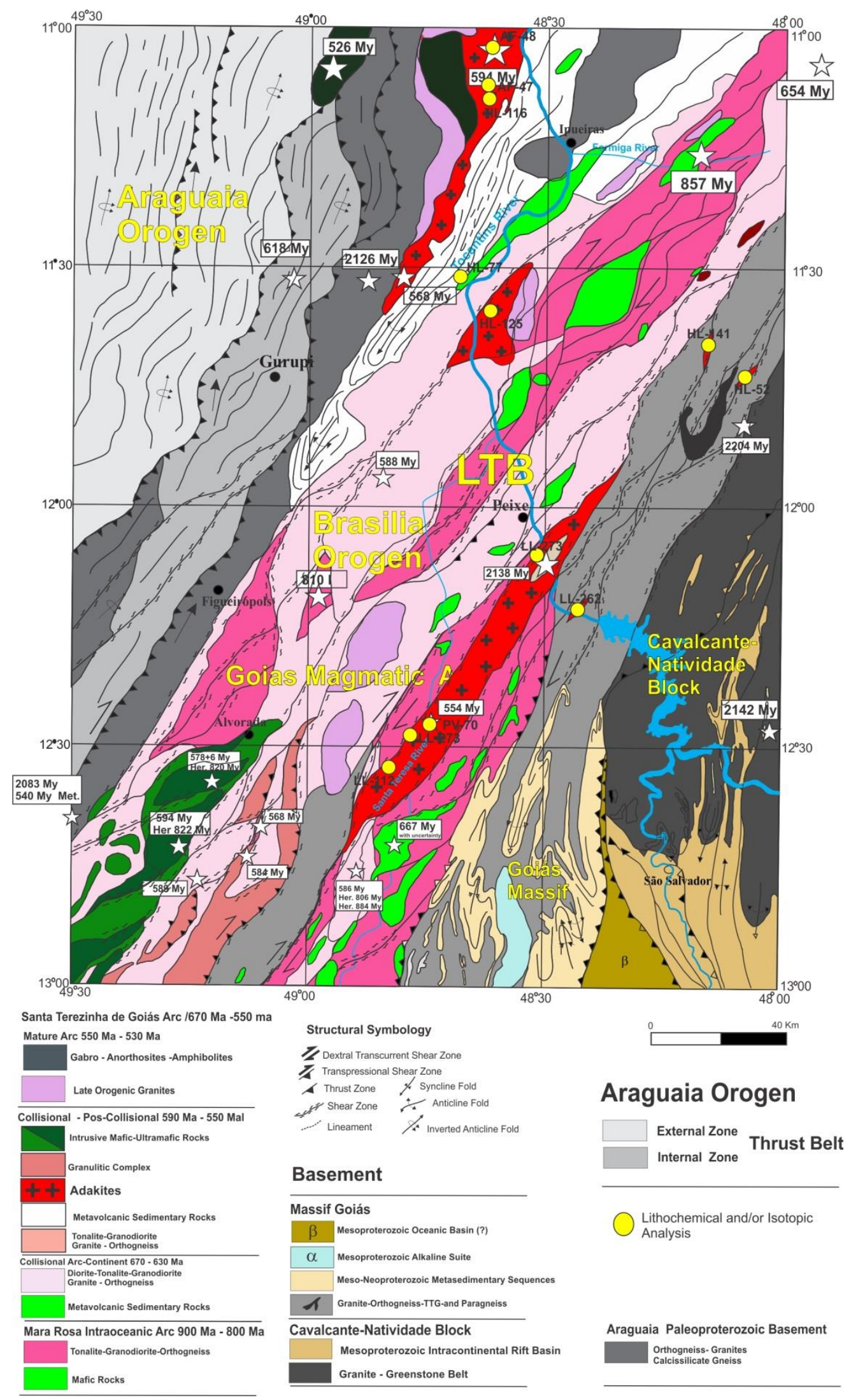

Fig.6.2 - Esboço geológico da área principal de estudo - Folhas Gurupi e Alvorada 1:250.000. Em tons avermelhados área do Arco Magmático de Goiás - Arcos de Mara Rosa e Santa Terezinha de Goiás. Polígonos vermelhos representam áreas de ocorrência de rochas adakíticas. Estrelas brancas indicam idades $\mathrm{U}-\mathrm{Pb}$ de alguns compartimentos. 


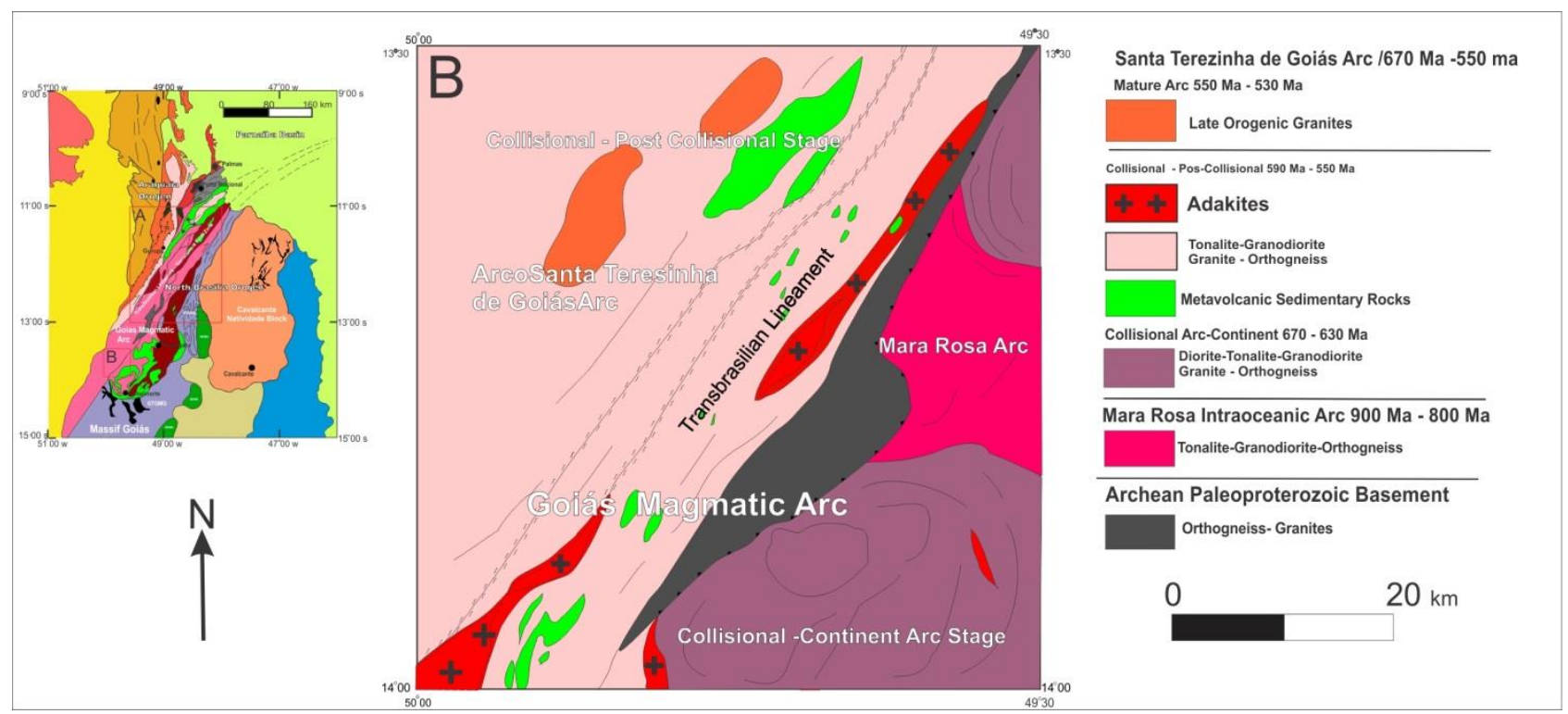

Fig. 6.3 - Esboço geológico da área secundária de estudo. Folha Bonópolis 1:100.000 mostrando partes do Arco Magmático de Goiás - Arcos de Mara Rosa e Santa Terezinha de Goiás. Área em vermelho representa ocorrência de rochas com tendência adakíticas.

As fases dominantes como fenocristais são geralmente plagioclásio $\left(\operatorname{An}_{(<50)}\right.$ e hornblenda. $\mathrm{O}$ plagioclásio é subédrico com tamanho desde $0.4 \mathrm{~mm}$ a $6 \mathrm{~mm}$, forma também a matriz e apresenta a proporção de $25 \%-60 \%$ em volume da rocha. Hornblenda ocorre como fenocristais e como porfiroblastos, pertence à série edenita-ferroedenita e fases mais ricas em $\mathrm{Na}$. Os cristais são euédricos a subédricos com granulação varável de 0.4 a 2 mm e $10 \%$ a $18 \%$ em volume. Estes dois minerais são os principais responsáveis pelos altos teores de $\mathrm{Na}$ nas rochas.

Os demais minerais componentes principais são quartzo (20\%-35\%), biotita (8\%-15\%), e feldspato alcalino (microclinio) com 3\%-15\% da rocha. Minerais varietais, acessórios e secundários são augita, titanita, apatita, zircão, opacos, granada, muscovita, clorita, e epidoto (tabela 6.1). A figura 6.4 exemplfica minerais e texturas das rochas.

A reação retrometamórfica mais comum é a passagem de Hornblenda $($ Anf $)=$ Biotita+ Quartzo+Opacos Em raros tonalitos e granodioritos gnaisses é possível observar hornblenda de origem

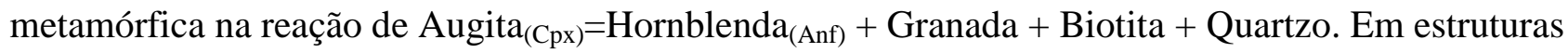
gnáissicas e ou miloníticas há intenso estiramento mineral sob cisalhamento simples, com a formação de cristais sigmoides do tipo " $\delta$ " e “ $\tau$ ” sin-cinemáticos, preferencialmente dextrais em transcorrências e up-dip em zonas transpressionais. $\mathrm{O}$ bandamento é estreito, curto e descontínuo a contínuo em zonas com foliação milonítica sobreposta. Estruturas dobradas, dobras sem raiz marcando mais de uma fase ou interferência deformacional são comuns. 


\begin{tabular}{|c|c|c|c|}
\hline Amostras & Rocha & Minerais Principais & Minerais Acessórios \\
\hline AF-47 & Hb-Bt Tonalito-Granodiorito & Plg 50\% - Qz 26\% - Hb $10 \%$ - Bt $12 \%$ & Al $1 \%$ - Tit $1 \%$ \\
\hline AF-48A & Bt-Hb MetaTonalito & Plg 57\% - Qz 16\% - Hb 14\% - Bt 10\% - & $\begin{array}{c}\text { Ep }<1 \%-\text { Tit } 1 \%-\text { Ap }<1 \%-\text { Op } 2 \%-\text { Clor }<1 \%- \\
Z r<1 \%\end{array}$ \\
\hline HL-116 & Hb-Bt Metatonalito & Plg 54\% - Qz30\% - Hb 5\% - Bt 8\% -KF $1 \%$ & Ap $<1 \%-$ Tit $2 \%$ \\
\hline HL 125 & Tonalito Gnaisse & Plg 46\% - Qz15\% - Hb 18\% - Bt 12\% -KF 5\% & $\begin{array}{c}\text { Ep }<1 \%-A p<1 \%-\text { Al } 1 \%-\text { Clor } 1 \%-Z r<1 \%- \\
\text { Tit3\% }\end{array}$ \\
\hline HL 77 & Bt-Tonalito & Plg 38\% - Qz35\% - Ep 8\% - Bt 10\% -KF 5\% & Clor $<1 \%$ - Ap $<1 \%$ - Tit $<1 \%$ - Op $3 \%$ \\
\hline LL-112 & Bt Granodiorito & Plg 48\% -KF 3\%- Qz 30\%- Hb -8\% -Bt 30\% & Tit 2\% - Al $<1 \%-$ Ep $<1 \%-A p<1 \% \quad Z r<1 \%-$ \\
\hline LM-123 & Hb Bt Tonalito Gnaisse & Plg 35\% -KF 5\%- Qz 28\%- Hb -15\% -Bt 10\% & $\begin{array}{c}\text { Tit } 1 \%-\mathrm{Al}<1 \%-\text { Ap } 1 \% \mathrm{Zr}<1 \%-\text { Op } 4 \%-\text { Cal } \\
1 \%\end{array}$ \\
\hline LM-150 & Monzogranito Gnaisse & $\begin{array}{c}\text { Plg } 22 \% \text {-KF 18\%- Qz 25\%- Musc 10\%- Ep - } 10 \% \text {-Bt } \\
13 \%\end{array}$ & Tit $2 \%-A p<1 \%-O p<1 \%$ \\
\hline LM-204 & Metagranodiorito-Tonalito & Plg 52\% - KF 12\% - Qz 28\% - Bt 18\% & $A p<1 \%-Z r<1 \%$ \\
\hline HL-141 & Bt Granodiorito Tonalito milonitico & Plg 25\% - Qz 45\%- KF - $10 \%$-Bt 18\% - Clor $2 \%$ & $A p<1 \%-G r<1 \%$ \\
\hline HL052 & BT tonalito gnaisse & Plg $43 \%$ - Qz 21\%- KF - $15 \%$-Bt $18 \%$ - Clor $2 \%$ & Ap (Tr) - Tit (Tr) - Ep (Tr) - Zr (Tr) -Carb (Tr) \\
\hline LL-273A & hb-bt metatonalito, bt mo Gnaisse & Plg $40 \%$ - Qz 20\% - Kf $15 \%$ - Bt $15 \%$ - Hb $10 \%$ & Tit<1\% - Zr <1\% - Al (?) - Opc (?)\% \\
\hline LL-262A & Bt-Tonalito & Plg $45 \%$ - Qz $30 \%$ - Kf $10 \%$ - Bt $15 \%$ & $\begin{array}{c}-\mathrm{Zr}<1 \%-\text { Carb }<1 \%-\text { Tit }<1 \%-\text { Ap }<1 \%- \\
\text { Fluo }<1 \%\end{array}$ \\
\hline PV-070 & $\begin{array}{c}\text { Bt-Granodiorito Protomilonito / } \\
\text { Gnaisse }\end{array}$ & Qz $35 \%$ - KF $10 \%$ - Plg $40 \%$ - Bt $15 \%$ & 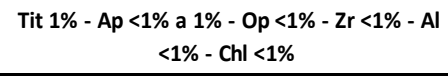 \\
\hline
\end{tabular}

Tabela 6.1 - Composição modal das rochas de tendência adakitica, classificação e volume da mineralogia principal e acessória: Plg: plagioclásio Qz: quartzo, Hb: hornblenda; KF: Feldspato Alcalino, Bt: biotita, Ap: apatita; Ep: Epidoto, Al: Allanita; Op: oxidos, Tit: Titanita; Zr: Zircão. chl: chlorita, Gr: Granada, carb: Carbonato, Clor: Clorita. 


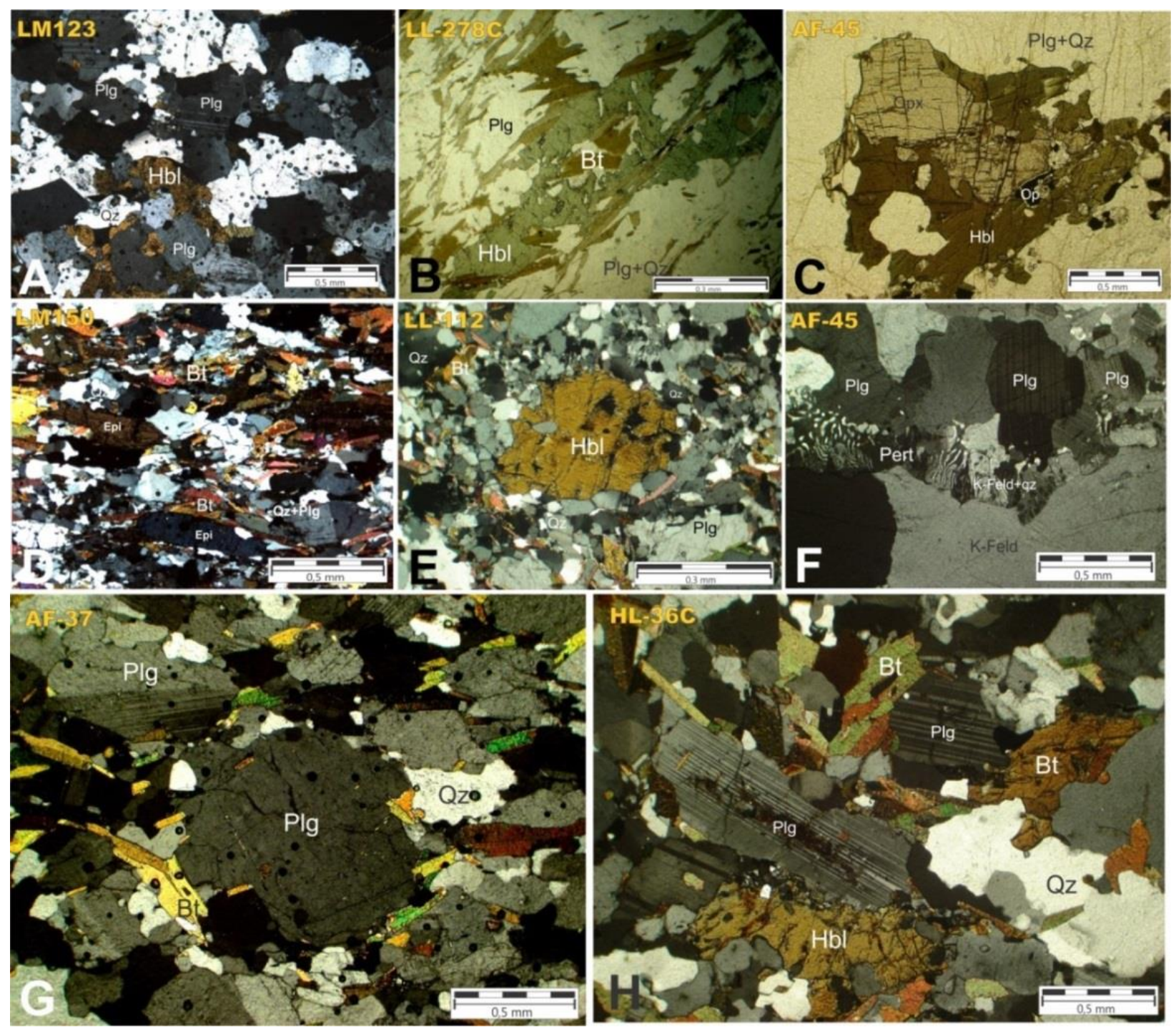

Fig. 6.4 - Lâminas delgadas de tonalitos e granodioritos adakiticos da porção setentrional do orógeno Brasília, mostram rochas adakiticas com graus variados de deformação e metamorfismo. A) Hornblenda metatonalito com textura grano-nemato-lepidoblástica poligonal, início de processo de recristalização; B) Hornblenda tonalito com porfiroblastos de Hb rotacionados dextrais com sobrecrescimento metamórfico de biotita ao longo das bordas e internos marcando foliação; C) Opx Tonalito, hiperstênio ígneo com substituição secundária de hornblenda. D) Biotita granodiorito gnaisse com epidoto, textura nemato e lepidoblasticas marcando foliação em inicio de bandamento metamórfico; E) Porfiroclasto de hornblenda em matriz quartzo+plagioclásio, textura granoblástica poligonal pouco deformada; F) Granodioritos com pertitas; G) e H) Cristais de plagioclásio e hornblenda em metatonalitos, resquícios de texturas ígneas preservadas.

\section{4 - Métodos Analíticos}

As análises químicas foram realizadas para elementos maiores $\mathrm{SiO}_{2}, \mathrm{TiO}_{2}, \mathrm{Al}_{2} \mathrm{O}_{3}, \mathrm{Fe}_{2} \mathrm{O}_{3}$, $\mathrm{MnO}, \mathrm{MgO}, \mathrm{CaO}, \mathrm{Na}_{2} \mathrm{O}, \mathrm{K}_{2} \mathrm{O}, \mathrm{P}_{2} \mathrm{O}_{5}, \mathrm{Cr}_{2} \mathrm{O}_{3}$, LOI, determinados por ICP-ES; os elementos traço Mo, 
$\mathrm{Cu}, \mathrm{Pb}, \mathrm{Zn}, \mathrm{As}, \mathrm{Cd}, \mathrm{Sb}, \mathrm{Bi}, \mathrm{Ag}, \mathrm{Au}, \mathrm{Hg}, \mathrm{Tl}, \mathrm{Se}, \mathrm{Sc}, \mathrm{Ba}, \mathrm{Be}, \mathrm{Co}, \mathrm{Cs}, \mathrm{Ga}, \mathrm{Hf}, \mathrm{Nb}, \mathrm{Rb}, \mathrm{Sn}, \mathrm{Sr}, \mathrm{Ta}, \mathrm{Th}$, $\mathrm{U}, \mathrm{V}, \mathrm{W}, \mathrm{Zr}$, Y, e 14 ETR foram determinados por ICP-MS a partir de fusão de $\mathrm{LiBO}_{2}$ e realizados na ACME Labs. Foram analisadas 16 amostras de composição tonalítica a granodiorítica, para comparação, com o objetivo identificar conjuntos semelhantes e compreender sua natureza geológica evolutiva. As análises U-Pb e Sm-Nd foram realizadas no Laboratório de Geocronologia da Universidade de Brasília - UnB.

Um conjunto de 9 amostras foi tratada pelo método Sm-Nd e 4 foram separadas para análise U-Pb em zircão. Os concentrados de zircão foram extraídos a partir de 5 a $10 \mathrm{~kg}$ de amostras de rochas, inicialmente analisados em separador magnético Frantz.

Para as análises LA-ICPMS, os grãos de zircão foram montados em blocos de epóxi e polidos para obter superfície nivelada. As imagens de catodoluminescência foram obtidas por escaneamento em microscópio eletrônico e utilizadas para investigar as estruturas internas dos cristais. Antes das análises LA-ICPMS, os moldes foram limpos em $\mathrm{HNO}_{3}$ diluído (c. 2\%). Depois de completamente secas, as amostras foram montadas em uma célula de laser especialmente adaptada para seções polidas, e carregada em UP213 laser Nd: YAG $(\lambda=213 \mathrm{~nm})$ ligado a ICPMS Neptune. Utilizou-se hélio como gás transportador e misturou-se com Ar antes de entrar no ICP. Cada análise foi estudada e apenas os intervalos coerentes, com ausência de sinais de idade mista ou interceptos de fase secundária ou quebras foram escolhidos para o cálculo da idade final. Normalização para GJ zircão padrão (608,5 — 1,5 Ma; Jackson et al., 2004) e cálculos de idade foram realizados utilizando uma planilha em Excel desenvolvido internamente no laboratório, baseado em fórmulas ISOPLOT v.3 (Ludwig, 2003). ${ }^{204} \mathrm{Hg}$ e ${ }^{202} \mathrm{Hg}$ foram medidos para avaliar a interferência isobárica no ${ }^{204} \mathrm{~Pb}$. Correções para $\mathrm{Pb}$ comum foram realizadas nas análises apresentando razões ${ }^{206} \mathrm{~Pb} /{ }^{204} \mathrm{~Pb}$ inferiores a 1000, utilizando o modelo de idade de cristalização de Stacey e Kramers (1975). Os dados U-Pb foram obtidos no programa ISOPLOT v.3 (Ludwig, 2003). O anexo 1 apresenta os resultados.

Para as análises isotópicas de $\mathrm{Sm}-\mathrm{Nd}$, realizadas no Laboratório de Geocronologia da Universidade de Brasília, foi seguido o método descrito por Gioia e Pimentel (2000), no qual 50 mg de pó de rocha total foram misturados com solução padrão com ${ }^{149} \mathrm{Sm}^{-150} \mathrm{Nd}$ e dissolvidos em cápsulas Savillex. A extração de $\mathrm{Sm}$ e $\mathrm{Nd}$ seguiu técnicas de permuta iônica convencionais, usando colunas de teflon contendo resina LN-Spec (ácido fosfórico HDEHP-diethylhexil suportado em pó PTFE). Amostras foram carregadas em filamentos de evaporação de Re e as medidas isotópicas foram realizadas em espectrômetro de massa multicoletor Finnigan MAT262 em modo estático. Incertezas para as razões $\mathrm{Sm} / \mathrm{Nd} \mathrm{e}{ }^{143} \mathrm{Nd} /{ }^{144} \mathrm{Nd}$ obtidas são melhores do que $\pm 0,5 \%(2 \sigma)$ e $\pm 0,005 \%(2 \sigma)$, respectivamente, baseadas em repetidas análises dos padrões de rocha internacional BHVO-1 e BCR-1. As razões ${ }^{143} \mathrm{Nd} /{ }^{144} \mathrm{Nd}$ e foram normalizadas para ${ }^{146} \mathrm{Nd} /{ }^{144} \mathrm{Nd}$ de 0,7219 e a constante de 
decaimento utilizada foi $6,54 \times 10^{-12} \mathrm{a}^{-1}$. Os valores $\mathrm{T}_{\mathrm{DM}}$ foram calculados com base no modelo de DePaolo (1981).

\section{Resultados}

\subsection{U-Pb Zircão e Saturação de Zircão}

Foram datados dois dos três maiores corpos encontrados na área de estudo, duas datações no corpo adakitico a norte, em suas duas extremidades e uma datação no corpo longelineo central. Foram analisados três afloramentos para datação pelo método U-Pb em zircão magmático. A amostra TA29 representa a idade do magmatismo colisional a pós colisional marcada na concórdia de idade



$\mathrm{Na}$ amostra PV-070 de afloramento de tonalito gnaisse na porção central e próximo ao rio Santa Teresa, foram realizados 29 spots em zircão magmático, que indicam idade de 554.0 £6.1 Ma. Os gráficos da fig. 6.5 e o anexo I apresentam os resultados. As idades obtidas até momento indicam magmatismo de idade ediacarana.

Para a amostra AUR-4 de um monzogranito-granodiorito, foram realizadas 23 determinações pontuais em zircão. Seus cristais apresentam-se euédricos, longos e prismáticos. Foram obtidas


apresent idades mais antigas e de menor confiabilidade com idades em 630 8 Ma e MSWD de 1.4. As idades mais jovens são consideradas como as idades de cristalização, a mais antiga como herança. A amostra TA14 apresenta as mesmas caracteristicas de idade de cristaliazação para rochas de


Concórdias das amostras estão representadas na figura 6.5.

Os adakitos intrusivos em áreas do embasamento não foram datados pelo método U-Pb. Todavia, os isótopos de $\mathrm{Sm}-\mathrm{Nd}$ indicam idades modelo bem mais antigas e de alta residência crustal, em torno de $2.3 \mathrm{Ga}$.

Cálculos da saturação de zircão realizados na química total de 15 amostras de adakitos jovens indicam, com temperatura mínima estipulada na fórmula para inicio de cristalização em $850^{0}$, temperaturas de cristalização do magma entre $855^{\circ}-711^{0}$, em média $773^{0}$, compatíveis com a janela de equilíbrio e geração de magmas adakíticos, (tabela 6.2, Fig 6.6) (Watson \& Harrison, 1983; Thorkelson e Breitsprecher, 2005). 

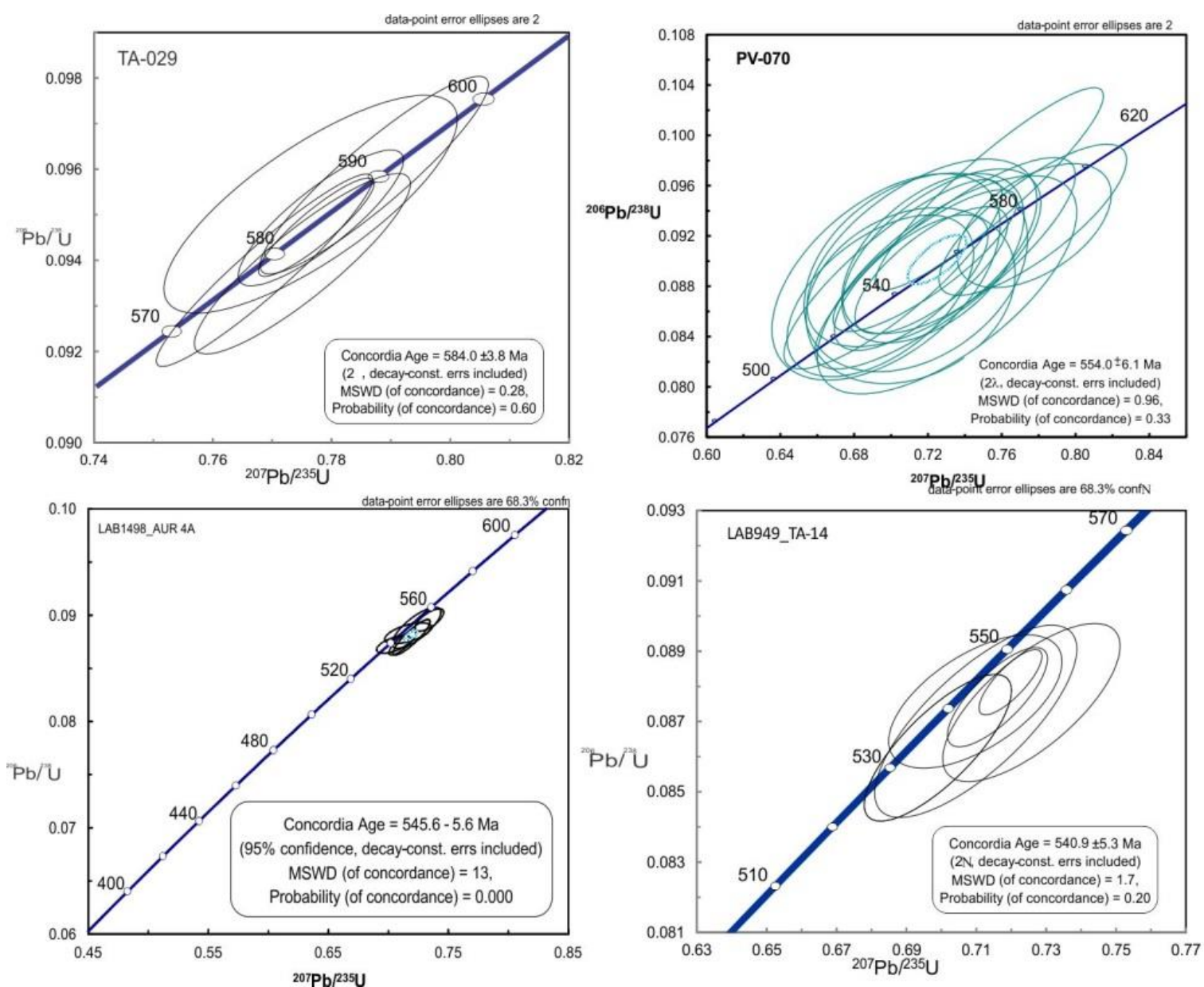

Fig. 6.5 - Diagramas concórdia dos adakitos do setor setentrional do Orógeno Brasília. As idades ediacaranas são coerentes com eventos tardios e pós-colisionais na formação de W-Gondawna.

\begin{tabular}{|c|c|c|c|c|c|c|c|}
\hline Sample & SiO2 \% & TiO2 \% & Zr -ppm & $\mathrm{M}$ & Zr.obs & Zr.sat & TZr.sat.C \\
\hline \multicolumn{8}{|c|}{ Neoproterozoic Adakites } \\
\hline AF 47 & 65.18 & 0.61 & 258.0 & 1.59 & 258.00 & 376.8 & 814.1 \\
\hline AF 48A & 58.40 & 0.77 & 279.9 & 2.05 & 279.90 & 556.5 & 786.6 \\
\hline HL 116 & 61.97 & 0.76 & 190.7 & 1.75 & 190.7 & 433.1 & 775.1 \\
\hline HL 125 & 62.94 & 0.60 & 97.9 & 1.9 & 97.90 & 492.2 & 711.6 \\
\hline HL 77 & 69.51 & 0.62 & 162.5 & 1.48 & 162.5 & 344.7 & 781 \\
\hline LL 112 & 68.01 & 0.51 & 243.1 & 1.52 & 243.1 & 355.3 & 814.1 \\
\hline PV 070 & 70.01 & 0.56 & 372.2 & 1.5 & 372.2 & 350.5 & 855.9 \\
\hline LM-123 & 67.16 & 0.36 & 118.3 & 1.68 & 118.3 & 407.6 & 740.8 \\
\hline LM-150 & 61.94 & 0.69 & 171.9 & 1.77 & 171.9 & 438.7 & 765.3 \\
\hline LM-204 & 69.95 & 0.34 & 148.7 & 1.47 & 148.7 & 339.6 & 774.7 \\
\hline LM-246B & 68.57 & 0.26 & 158.5 & 1.45 & 158.5 & 334.5 & 781.4 \\
\hline HL 52 & 68.58 & 0.34 & 133.1 & 1.44 & 133.1 & 333.2 & 766.9 \\
\hline LL 262A & 62.51 & 0.38 & 98.0 & 1.79 & 98 & 447.6 & 718.8 \\
\hline LL-273A & 63.60 & 0.52 & 174.0 & 1.74 & 174 & 429.5 & 768.1 \\
\hline LL-278A & 65.20 & 0.47 & 126.9 & 1.66 & 126.9 & 401.1 & 747.7 \\
\hline
\end{tabular}

Tabela 5.2 - Cálculo de saturação de zircão: Dados principais de elementos observados na tabela 2 (quimica de rocha e concentrações $\mathrm{Zr}$ ), assumindo o resultado final como a temperatura do magma para cada amostra. Detalhes de cáculo dos parâmetros M, Zr. Obs e TZr.sat.C em Watson \& Harrison (1983). 




Fig. 6.6 - Diagrama de pressão e temperatura Vs. equilíbrio de fases de Thorkelson e Breitsprecher, (2005), campo em cinza indica as condições favoráveis para gênese de magmas adakíticos, pontos em vermelho, amarelo e beje indicam temperaturas máxima, média e mínima calculadas, a partir das análises de saturação de zircão. As condições de pressão são inferidas com base nos dados obtidos na análise petrogenética.

\subsection{Geoquímica}

Os dados químicos estão apresentados na tabela 6.3. As rochas são de constituição petrográfica muito semelhante. Ocorrem detalhes químicos sutis e diferenças substanciais quanto à sua identidade isotópica que permitem diferenciá-los em dois grupos quimicamente ricos em $\mathrm{Na}_{2} \mathrm{O}$. O padrão normal caracteriza um conjunto de rochas de tendência adakítica intrusiva no Maciço de Goiás, que foram tratados em certos diagramas de forma a parte e um segundo grupo, ao qual se dará ênfase; de ocorrência interna ao AMG.

\subsection{1. -Geoquímica de Elementos Maiores e Traço - "Adakitos Tipo I "}

Os adakitos do tipo I são intrusivos no embasamento, são de natureza ácida, plotam no campo calci-alcalino (Fig 6.7A), metaluminosos a ligeiramente peraluminosos (Fig 6.7B). Nos óxidos a 


\begin{tabular}{|c|c|c|c|c|c|c|c|c|c|c|c|c|c|c|c|c|c|c|c|}
\hline \multirow[b]{2}{*}{$\begin{array}{l}\text { Sample } \\
\text { Rock }\end{array}$} & \multicolumn{12}{|c|}{ "Adakites Type II - AMG } & \multicolumn{4}{|c|}{ "Adakites type I } & \multicolumn{3}{|c|}{${ }^{*}$ All samples } \\
\hline & $\begin{array}{l}\text { AF } 47 \\
\text { Tonalite }\end{array}$ & $\begin{array}{l}\text { AF 48A } \\
\text { Qz-Diorite }\end{array}$ & $\begin{array}{l}\text { HL } 116 \\
\text { Tonalite }\end{array}$ & $\begin{array}{l}\text { HL } 125 \\
\text { Tonalite }\end{array}$ & $\begin{array}{l}\text { HL } 77 \\
\text { Tonalite }\end{array}$ & $\begin{array}{c}\text { LL } 112 \\
\text { Granodiorite }\end{array}$ & $\begin{array}{c}\text { PV } 070 \\
\text { Granodiorite }\end{array}$ & $\begin{array}{c}\text { LM-123 } \\
\text { Granodiorite }\end{array}$ & $\begin{array}{c}\text { LM-150 } \\
\text { Monzodiorite }\end{array}$ & $\begin{array}{l}\text { LM-204 } \\
\text { Granite }\end{array}$ & $\begin{array}{c}\text { LM-246B } \\
\text { Granite }\end{array}$ & $\begin{array}{l}\text { LL-273A } \\
\text { tonalite }\end{array}$ & $\begin{array}{c}\text { HL } 52 \\
\text { Granodiorite }\end{array}$ & $\begin{array}{l}\text { LL262A } \\
\text { Tonalite }\end{array}$ & $\begin{array}{c}\text { HL } 141 \\
\text { Granodiorite } \\
\text { Tonalite }\end{array}$ & $\begin{array}{c}\text { LI-278A } \\
\text { Granodiorite }\end{array}$ & Average & Max & Min \\
\hline SiO2 & 65.18 & 58.40 & 61.97 & 62.94 & 69.51 & 68.01 & 70.01 & 67.16 & 61.94 & 69.95 & 68.57 & 63.60 & 68.58 & 62.51 & 70.06 & 65.20 & 65.85 & 58.40 & 70.06 \\
\hline Al203 & 16.74 & 17.30 & 17.40 & 16.26 & 13.56 & 15.3 & 14.54 & 15.45 & 17.14 & 15.47 & 15.74 & 15.7 & 16.22 & 16.72 & 15.35 & 15.2 & 15.88 & 13.56 & 17.40 \\
\hline Fe203T & 3.99 & 6.46 & 4.60 & 4.87 & 4.90 & 4.68 & 2.80 & 4.12 & 5.04 & 2.78 & 2.57 & 8.51 & 3.10 & 5.61 & 3.54 & 8.38 & 4.75 & 2.57 & 8.51 \\
\hline $\mathrm{MgO}$ & 1.38 & 3.79 & 2.36 & 2.93 & 1.67 & 1.18 & 0.71 & 1.38 & 2.27 & 0.91 & 0.68 & 2.76 & 0.78 & 2.36 & 0.94 & 2.88 & 1.81 & 0.68 & 3.79 \\
\hline $\mathrm{CaO}$ & 3.51 & 6.35 & 4.18 & 5.60 & 3.27 & 3.11 & 1.78 & 3.82 & 4.45 & 2.68 & 2.17 & 4.61 & 2.57 & 4.69 & 2.63 & 3.84 & 3.70 & 1.78 & 6.35 \\
\hline $\mathrm{Na} 2 \mathrm{O}$ & 4.33 & 4.47 & 4.56 & 4.42 & 3.55 & 4.01 & 3.76 & 4.56 & 4.76 & 4.67 & 5.20 & 4.31 & 5.51 & 4.49 & 4.38 & 4.22 & 4.45 & 3.55 & 5.51 \\
\hline K2O & 2.97 & 1.19 & 2.85 & 1.27 & 1.85 & 2.84 & 4.86 & 2.19 & 2.12 & 2.37 & 2.35 & 1.46 & 1.49 & 2.14 & 1.55 & 1.94 & 2.22 & 1.19 & 4.86 \\
\hline Ti02 & 0.61 & 0.77 & 0.76 & 0.60 & 0.62 & 0.51 & 0.56 & 0.36 & 0.69 & 0.34 & 0.26 & 0.52 & 0.34 & 0.38 & 0.43 & 0.47 & 0.51 & 0.26 & 0.77 \\
\hline P205 & 0.24 & 0.36 & 0.33 & 0.24 & 0.16 & 0.14 & 0.16 & 0.21 & 0.17 & 0.11 & 0.10 & 0.192 & 0.09 & 0.15 & 0.13 & 0.175 & 0.18 & 0.09 & 0.36 \\
\hline MnO & 0.05 & 0.13 & 0.06 & 0.08 & 0.06 & 0.09 & 0.03 & 0.07 & 0.08 & 0.04 & 0.04 & 0.07 & 0.05 & 0.04 & 0.04 & 0.08 & 0.06 & 0.03 & 0.13 \\
\hline $\mathrm{Cr}_{2} \mathrm{O3}$ & 0.00 & 0.01 & 0.01 & 0.01 & 0.01 & 0.002 & 0.00 & 0.003 & 0.006 & $<0.002$ & $<0.002$ & $<0,01$ & 0.00 & 0.01 & 0.00 & 0.01 & 0.01 & 0.00 & 0.01 \\
\hline LOI & 0.60 & 0.40 & 0.50 & 0.90 & 0.70 & 0.6 & 0.50 & 0.4 & 1.1 & 0.5 & 2.2 & 0.63 & 1.00 & 0.80 & 1.00 & 0.8 & 0.79 & 0.40 & 2.20 \\
\hline SUM & 99.60 & 99.63 & 99.58 & 100.13 & 99.87 & 100.47 & 99.71 & 99.74 & 99.79 & 99.82 & 99.85 & 101.10 & 99.74 & 99.90 & 100.05 & 101.51 & 100.0 & 99.6 & 101.5 \\
\hline Mo & 1.00 & 1.10 & 1.20 & 1.80 & 1.40 & 0.2 & 0.20 & 0.2 & 0.4 & 0.2 & 0.2 & 0.36 & 2.60 & 1.00 & 1.20 & 0.46 & 0.85 & 0.20 & 2.60 \\
\hline $\mathrm{Cu}$ & 3.30 & 13.20 & 13.50 & 45.80 & 178.70 & 3.4 & 22.10 & 3.9 & 26.4 & 24.4 & 4.1 & 31 & 3.20 & 149.20 & 5.60 & 7 & 33.43 & 3.20 & 178.70 \\
\hline $\mathrm{Pb}$ & 0.90 & 0.80 & 0.80 & 0.90 & 0.80 & 2.1 & 3.50 & 1.5 & 1.2 & 2.3 & 5.5 & 2.8 & 2.30 & 10.10 & 1.00 & 9.3 & 2.86 & 0.80 & 10.10 \\
\hline $\mathrm{Zn}$ & 49.00 & 40.00 & 46.00 & 36.00 & 39.00 & 56 & 64.00 & 53 & 53 & 49 & 50 & 47 & 62.00 & 191.00 & 55.00 & 56 & 59.13 & 36.00 & 191.00 \\
\hline $\mathrm{Ni}$ & 11.80 & 15.60 & 26.60 & 38.10 & 31.50 & 6.9 & 5.00 & 9.9 & 28.2 & 9.6 & 5.3 & 37.9 & 5.10 & 29.10 & 10.10 & 34.5 & 19.08 & 5.00 & 38.10 \\
\hline $\mathrm{Ba}$ & 2614.50 & 1243.10 & 1814.70 & 363.00 & 524.40 & 1136.4 & 1557.10 & 1023 & 652 & 524 & 621 & 459 & 272.90 & 287.90 & 356.80 & 232 & 855.11 & 232.00 & 2614.50 \\
\hline $\mathrm{Be}$ & 1.00 & 1.00 & 1.00 & 1.00 & 1.00 & 3 & 3.00 & 2 & 1 & 1 & 3 & 2.2 & 4.00 & 8.00 & 2.00 & 2 & 2.26 & 1.00 & 8.00 \\
\hline Co & 9.40 & 18.60 & 15.10 & 16.80 & 11.40 & 7.8 & 4.20 & 7.1 & 13.3 & 7.8 & 4.4 & 15.8 & 4.60 & 12.90 & 6.90 & 14.1 & 10.64 & 4.20 & 18.60 \\
\hline Cs & 1.10 & 0.50 & 0.60 & 1.30 & 1.90 & 1.8 & 0.70 & 0.8 & 1.4 & 1.6 & 5.8 & 1.23 & 6.10 & 1.80 & 1.20 & 1.8 & 1.85 & 0.50 & 6.10 \\
\hline Ga & 20.50 & 22.60 & 22.40 & 18.00 & 15.20 & 20.6 & 20.40 & 17.7 & 18.0 & 19.6 & 20.7 & 20.7 & 24.10 & 25.20 & 24.40 & 20.2 & 20.64 & 15.20 & 25.20 \\
\hline $\mathrm{Hf}$ & 6.10 & 7.40 & 5.40 & 2.70 & 5.00 & 6.7 & 9.80 & 3.8 & 4.5 & 3.8 & 4.7 & 4.74 & 4.30 & 2.60 & 7.60 & 3.13 & 5.14 & 2.60 & 9.80 \\
\hline $\mathrm{Nb}$ & 9.80 & 8.80 & 12.10 & 6.50 & 10.00 & 9.9 & 8.90 & 6.3 & 9.2 & 7.7 & 7.3 & 0.79 & 6.50 & 15.50 & 8.40 & 2.52 & 8.14 & 0.79 & 15.50 \\
\hline $\mathrm{Rb}$ & 46.40 & 21.50 & 53.80 & 43.30 & 58.50 & 85.3 & 165.20 & 50.9 & 51.5 & 69.2 & 111.8 & 63.2 & 74.40 & 139.50 & 87.30 & 96.8 & 76.16 & 21.50 & 165.20 \\
\hline Sn & 1.00 & $<1$ & 1.00 & $<1$ & 2.00 & 3 & 2.00 & 2 & $<1$ & 2 & 3 & 1.8 & 3.00 & 2.00 & $<1$ & 2 & 1.98 & 1.00 & 3.00 \\
\hline $\mathrm{Sr}$ & 923.80 & 1283.30 & 1164.00 & 621.70 & 284.00 & 556.00 & 369.30 & 800.20 & 496.20 & 439.90 & 365.50 & 963.30 & 509.10 & 479.30 & 293.70 & 550.10 & 631.21 & 284.00 & 1283.30 \\
\hline $\mathrm{Ta}$ & 0.50 & 0.40 & 0.70 & 0.40 & 0.70 & 0.7 & 0.60 & 0.3 & 0.5 & 0.3 & 0.6 & 0.53 & 0.50 & 0.80 & 0.40 & 0.48 & 0.53 & 0.30 & 0.80 \\
\hline Th & 6.00 & 4.30 & 6.20 & 4.20 & 5.50 & 5.5 & 36.90 & 3.7 & 6.1 & 4.6 & 17.2 & 12.4 & 4.70 & 1.70 & 15.20 & 9.3 & 8.97 & 1.70 & 36.90 \\
\hline U & 0.90 & 0.90 & 0.70 & 1.40 & 1.40 & 0.7 & 1.30 & 0.7 & 1.0 & 1.1 & 3.1 & 0.96 & 0.90 & 0.80 & 1.00 & 0.61 & 1.09 & 0.61 & 3.10 \\
\hline V & 35.00 & 88.00 & 62.00 & 103.00 & 93.00 & 33 & 35.00 & 68 & 86 & 58 & 34 & 61 & 30.00 & 68.00 & 27.00 & 60 & 58.81 & 27.00 & 103.00 \\
\hline W & 0.10 & 0.10 & 0.20 & 0.10 & 0.20 & 0.1 & 0.80 & $<0.5$ & $<0.5$ & $<0.5$ & $<0.5$ & 0.4 & 4.20 & 2.50 & 0.40 & 0.5 & 0.73 & 0.10 & 4.20 \\
\hline $\mathrm{Zr}$ & 258.00 & 279.90 & 190.70 & 97.90 & 162.50 & 243.1 & 372.20 & 118.3 & 171.9 & 148.7 & 158.5 & 174 & 133.10 & 98.00 & 251.10 & 126.9 & 186.55 & 97.90 & 372.20 \\
\hline$Y$ & 13.30 & 17.10 & 10.10 & 16.70 & 22.20 & 25 & 9.30 & 17.4 & 12.0 & 13.7 & 11.4 & 9.34 & 4.30 & 15.50 & 9.30 & 12.08 & 13.67 & 4.30 & 25.00 \\
\hline La & 36.40 & 41.30 & 53.40 & 29.20 & 29.20 & 40 & 97.80 & 16.6 & 27.4 & 23.2 & 33.8 & 44.8 & 26.10 & 19.90 & 56.30 & 33.5 & 38.06 & 16.60 & 97.80 \\
\hline $\mathrm{Ce}$ & 80.60 & 90.40 & 97.00 & 59.00 & 62.30 & 87.4 & 167.50 & 34.5 & 52.7 & 44.2 & 55.2 & 83.7 & 50.50 & 39.00 & 117.60 & 66.1 & 74.23 & 34.50 & 167.50 \\
\hline $\mathrm{Pr}$ & 8.34 & 9.87 & 9.55 & 6.28 & 7.02 & 9.21 & 17.51 & 4.30 & 5.68 & 5.08 & 6.49 & 8.76 & 5.16 & 4.83 & 11.54 & 7.37 & 7.94 & 4.30 & 17.51 \\
\hline $\mathrm{Nd}$ & 30.70 & 40.60 & 34.00 & 26.70 & 28.00 & 34.4 & 57.80 & 16.5 & 20.6 & 17.6 & 23.4 & 31.8 & 19.20 & 17.90 & 45.60 & 27.5 & 29.52 & 16.50 & 57.80 \\
\hline Sm & 5.30 & 7.00 & 5.20 & 5.10 & 5.20 & 5.3 & 7.20 & 3.62 & 3.53 & 2.92 & 4.11 & 4.3 & 2.60 & 4.40 & 7.00 & 5 & 4.86 & 2.60 & 7.20 \\
\hline Eu & 1.56 & 1.89 & 1.50 & 1.38 & 1.16 & 1.4 & 1.19 & 1.08 & 1.00 & 0.95 & 0.60 & 1.16 & 0.67 & 1.01 & 1.00 & 1.03 & 1.16 & 0.60 & 1.89 \\
\hline Gd & 3.50 & 4.29 & 2.84 & 3.65 & 3.93 & 4.11 & 4.18 & 3.45 & 2.85 & 2.56 & 3.25 & 2.76 & 1.60 & 3.38 & 3.92 & 3.22 & 3.34 & 1.60 & 4.29 \\
\hline $\mathrm{Tb}$ & 0.48 & 0.59 & 0.38 & 0.52 & 0.71 & 0.74 & 0.47 & 0.55 & 0.44 & 0.44 & 0.49 & 0.36 & 0.24 & 0.60 & 0.44 & 0.37 & 0.49 & 0.24 & 0.74 \\
\hline Dy & 2.44 & 2.90 & 1.79 & 2.74 & 3.92 & 4.23 & 2.11 & 2.94 & 2.34 & 2.21 & 2.45 & 1.8 & 0.81 & 2.94 & 1.86 & 2.43 & 2.49 & 0.81 & 4.23 \\
\hline Ho & 0.47 & 0.55 & 0.33 & 0.51 & 0.78 & 0.8 & 0.37 & 0.57 & 0.47 & 0.45 & 0.38 & 0.33 & 0.15 & 0.57 & 0.28 & 0.41 & 0.46 & 0.15 & 0.80 \\
\hline Er & 1.32 & 1.48 & 0.97 & 1.32 & 2.14 & 2.49 & 0.77 & 1.65 & 1.28 & 1.37 & 0.99 & 0.96 & 0.32 & 1.46 & 0.63 & 1 & 1.26 & 0.32 & 2.49 \\
\hline $\mathrm{Tm}$ & 0.18 & 0.21 & 0.12 & 0.23 & 0.35 & 0.37 & 0.12 & 0.28 & 0.21 & 0.20 & 0.14 & 0.14 & $<.05$ & 0.21 & 0.12 & 0.16 & 0.20 & 0.12 & 0.37 \\
\hline $\mathrm{Yb}$ & 1.14 & 1.37 & 0.78 & 1.07 & 1.95 & 2.37 & 0.73 & 1.72 & 1.34 & 1.11 & 0.82 & 0.7 & 0.27 & 1.25 & 0.58 & 0.9 & 1.13 & 0.27 & 2.37 \\
\hline Lu & 0.18 & 0.21 & 0.12 & 0.19 & 0.32 & 0.34 & 0.10 & 0.23 & 0.20 & 0.19 & 0.13 & 0.1 & 0.04 & 0.16 & 0.11 & 0.11 & 0.17 & 0.04 & 0.34 \\
\hline $\mathrm{K} 2 \mathrm{O} / \mathrm{Na} 20$ & 0.69 & 0.27 & 0.63 & 0.29 & 0.52 & 0.71 & 1.29 & 0.48 & 0.45 & 0.51 & 0.45 & 0.34 & 0.27 & 0.48 & 0.35 & 0.46 & 0.51 & 0.27 & 1.29 \\
\hline $\mathrm{K} 2 \mathrm{O}+\mathrm{Na} 2 \mathrm{O}$ & 7.30 & 5.66 & 7.41 & 5.69 & 5.40 & 6.85 & 8.62 & 6.75 & 6.88 & 7.04 & 7.55 & 5.77 & 7.00 & 6.63 & 5.93 & 6.16 & 6.67 & 5.40 & 8.62 \\
\hline$\# M g$ & 40.7 & 53.8 & 50.4 & 54.4 & 40.3 & 33.3 & 33.4 & 39.9 & 47.2 & 39.3 & 34.4 & 39.1 & 33.3 & 45.5 & 34.5 & 40.5 & 41.2 & 33.3 & 54.4 \\
\hline $\mathrm{Ba} / \mathrm{Rb}$ & 56.35 & 57.82 & 33.73 & 8.38 & 8.96 & 13.32 & 9.43 & 20.10 & 12.66 & 7.57 & 5.55 & 7.26 & 3.67 & 2.06 & 4.09 & 2.40 & 15.83 & 2.06 & 57.82 \\
\hline $\mathrm{Rb} / \mathrm{Sr}$ & 0.05 & 0.02 & 0.05 & 0.07 & 0.21 & 0.15 & 0.45 & 0.06 & 0.10 & 0.16 & 0.31 & 0.07 & 0.15 & 0.29 & 0.30 & 0.18 & 0.16 & 0.02 & 0.45 \\
\hline $\mathrm{Ta} / \mathrm{Th}$ & 0.08 & 0.09 & 0.11 & 0.10 & 0.13 & 0.13 & 0.02 & 0.08 & 0.08 & 0.07 & 0.03 & 0.04 & 0.11 & 0.47 & 0.03 & 0.05 & 0.10 & 0.02 & 0.47 \\
\hline $\mathrm{Sr} / \mathrm{Y}$ & 69.46 & 75.05 & 115.25 & 37.23 & 12.79 & 22.24 & 39.71 & 45.99 & 41.35 & 32.11 & 32.06 & 103.14 & 118.40 & 30.92 & 31.58 & 45.54 & 53.30 & 12.79 & 118.40 \\
\hline $\mathrm{La} / \mathrm{Yb}$ & 31.93 & 30.15 & 68.46 & 27.29 & 14.97 & 16.88 & 133.97 & 9.65 & 20.45 & 20.90 & 41.22 & 64.00 & 96.67 & 15.92 & 97.07 & 37.22 & 45.42 & 9.65 & 133.97 \\
\hline $\mathrm{La}(\mathrm{n})^{*}$ & 117.42 & 133.23 & 172.26 & 94.19 & 94.19 & 129.03 & 315.48 & 53.55 & 88.39 & 74.84 & 109.03 & 144.52 & 84.19 & 64.19 & 181.61 & 108.06 & 122.76 & 53.55 & 315.48 \\
\hline $\mathrm{Yb}(\mathrm{n})^{*}$ & 5.45 & 6.56 & 3.73 & 5.12 & 9.33 & 11.34 & 3.49 & 8.23 & 6.41 & 5.31 & 3.92 & 3.35 & 1.29 & 5.98 & 2.78 & 4.31 & 5.41 & 1.29 & 11.34 \\
\hline$(\mathrm{La} / \mathrm{Yb}) \mathrm{n}^{*}$ & 21.53 & 20.32 & 46.16 & 18.40 & 10.10 & 11.38 & 90.32 & 6.51 & 13.79 & 14.09 & 27.79 & 43.15 & 65.17 & 10.73 & 65.44 & 25.09 & 30.62 & 6.51 & 90.32 \\
\hline
\end{tabular}

Tabela 6.3 - Análises químicas das rochas de tendência adakítica no AMG (tipo II) e intrusivas no embasamento (tipo I). *As médias, máximas e mínimas apresentadas representam a totalidade das amostras.

distinção entre os dois grupos é tênue. Possuem $\mathrm{SiO}_{2}$ em média com valores de $66.59 \%$ em peso (intervalo de $62.51 \%$ a 70,06 \%), valores médios moderados a altos em $\mathrm{Al}_{2} \mathrm{O}_{3}$ de $15.87 \%$ (intervalo de $15.2 \%$ a $16,72 \%), \mathrm{FeO}$ com $5.16 \%, \mathrm{CaO}$ com $3,43 \%$, baixo em $\mathrm{K}_{2} \mathrm{O}(<1.78 \%), \mathrm{MgO}$ baixo na 
ordem de $1.74 \%$ e valores de \#Mg 45-33, em média 38, mostram altos teores de $\mathrm{Na}_{2} \mathrm{O}$, em geral, superiores a $4 \%(5.51 \%$ a $4.22 \%)$, com a razão $\mathrm{K}_{2} \mathrm{O} / \mathrm{Na}_{2} \mathrm{O}$ muito baixa (0.48-0.27, média 0.39).

Alguns metais de transição apresentam valores altos para rochas tonaliticas e granodioríticas, como $\mathrm{Pb}$ e Zn: média 5.6 ppm e média 91 ppm, respectivamente. Os elementos traço apresentam altas concentrações em Sr (550-293 ppm, média 458 ppm), Th (15.2-1.7 ppm, média 7.73 ppm), Zr (251-98 ppm, média 152.2 ppm), Y (15.5 -4.3 ppm, média 10.3 ppm) e elevadas razões Sr/Y (118 - 30.9, média 56.61) e teores moderadas de Ba (356-232 ppm, média 287.4 ppm),

Nos spidergramas normalizados pelo manto primitivo (Sun e McDonough, 1989, fig.6.7C) as rochas apresentam depleção moderada em $\mathrm{Ba}$, e marcante empobrecimento em $\mathrm{P}$, Ti, e principalmente $\mathrm{Nb}$, com valores próximos à unidade. Os padrões das curvas ETR normalizadas para condrito (Boynton, 1984, fig.6.7E), apresentam valores altos em ETRL e muito depletadas em ETRP e anomalias de Eu negligenciáveis. A razão La/Yb possui índices altos (97-15.9, média de 61.7). O valor da razão $\mathrm{La}_{(\mathrm{n})} / \mathrm{Yb}_{(\mathrm{n})}$ apresenta razão alta (65.4-10.7), sugerindo alto grau de fracionamento.

\subsubsection{Classificação Geoquímica - Elementos Maiores e Traço - “Adakitos Tipo II”}

As rochas de tendência adakíticas do arco neoproterozóico são em maioria rochas tonalíticas e granodioríticas calci-alcalinas (Fig 6.7A), de natureza intermediária a ácida e são metaluminosos a fracamente peraluminosos (Fig.6.7B). Possuem $\mathrm{SiO}_{2}$ em média com valores de $64.77 \%$ em peso, (intervalo de 53,62\% a 70,01 \%), Valores médios moderados a altos em $\mathrm{Al}_{2} \mathrm{O}_{3}$ de $16.02 \%$, (intervalo de $13.56 \%$ a $17.40 \%$ ), $\mathrm{FeO}$ com $4.77 \%$, (intervalo amplo de $10,40 \%$ a 2,57\%) e $\mathrm{CaO}$ com 3,99\%, baixo em $\mathrm{K}_{2} \mathrm{O}<2.37 \%$, e altos em $\mathrm{Na}_{2} \mathrm{O}$, em geral, superiores a $4 \%$. Apresentam $\mathrm{MgO}$ baixo na ordem de $1.86 \%$ e valores moderados a baixos de \#Mg (54-33, em média 42), Ni (média 16.2 ppm) e V (média $81 \mathrm{ppm}$ ) relativamente elevado para rochas ácidas. Algumas amostras possuem concentrações baixas em Ni em comparação aos adakitos atuais, que possuem em média 24 ppm, (Martin et al., 2005).

Os valores baixos da razão $\mathrm{K}_{2} \mathrm{O} / \mathrm{Na}_{2} \mathrm{O}<1(0.27-1.29$, média 0.55$)$, indicam praticamente o dobro de $\mathrm{Na}_{2} \mathrm{O}$ sobre o $\mathrm{K}_{2} \mathrm{O}$. Uma amostra apenas apresenta valores anômalos para relação $\mathrm{K}_{2} \mathrm{O} / \mathrm{Na}_{2} \mathrm{O}(>1.29)$, mas coerentes para as razões $\mathrm{Sr} / \mathrm{Y}$ e La/Yb, e padrões ETR comuns, o que pode sugerir mistura de magmas máficos ricos em K e fusão parcial de crosta inferior, Guo et al., 2007). Para classificação de Martin et al. (2005), podem ser considerados como adakitos de alta $\mathrm{Si}_{2} \mathrm{O}$ ( $\mathrm{HSA}, \mathrm{SiO}_{2}>60 \%$ ).

No diagrama AFM de Irvine e Baragar (1971), (Fig. 6.7A), pode-se ainda observar que todas as rochas plutônicas possuem convergência para o campo calci-alcalino em direção a baixos teores 
de $\mathrm{MgO}$ e baixo a moderado teor em K. As amostras, em geral, possuem elevado teor de $\mathrm{Na}_{2} \mathrm{O}$, $\mathrm{Al}_{2} \mathrm{O}_{3}$ (para $\mathrm{SiO}_{2}$ entre 60 e 70\%), e menores teores em $\mathrm{MgO}, \mathrm{CaO}, \mathrm{FeO}, \mathrm{TiO}_{2}, \mathrm{P}_{2} \mathrm{O}_{5}$. Ainda em relação a elementos maiores e fracionamento o gráfico $\mathrm{CaO} / \mathrm{Al}_{2} \mathrm{O}_{3}$ x FeOt/MgO (Fig.6.7A) mostra, conforme observado na petrografia, que as rochas tendem a fracionar anfibólio e plagioclásio e que os óxidos cristalizaram simultaneamente aos minerais ferro-magnesianos, conforme a correlação positiva do gráfico $\mathrm{TiO}_{2} \mathrm{X} \mathrm{MgO/(MgO+FeOt)} \mathrm{de} \mathrm{(Omrani} \mathrm{et} \mathrm{al.,} \mathrm{2008,} \mathrm{Fig.6.7B).}$

Os elementos traço são os melhores determinantes para caracterização dos adakitos do orógeno Brasília setentrional. As rochas apresentam concentrações muito altas em Ba (2614-363 ppm, média de 1044 ppm), Sr (1283-284 ppm, média de 688.9 ppm), Zr (372-97ppm, média 197.9 ppm), Y: (25-9.3 ppm, média de 14.8 ppm). Apesar das altas concentrações de Y, os valores de Sr são ainda maiores induzindo alta razão Sr/Y (115-13 média 52). Outras características são as altas concentrações em Th (média >9ppm) e altas razões Th/U (3-28, 8 média) superiores às encontradas nos adakitos atuais associados às zonas de subducção, Karsli et al. (2011).

Os ETRL são altos com La (97.8-16.3 ppm, média de 39.4 ppm), Ce (167-34 ppm, média de 76 ppm), Pr (17.5-4.3 ppm, média de 8.71 ppm), Nd (57.8 -16.5 ppm, média de 30.18 ppm), Sm (7.2- 2.9 ppm, média de 4.9 ppm), com valores baixos de ETRP baixo, como Yb (2.3 - 0.7 ppm). Os índices da razão La/Yb (133.9 - 9.65, média de 39.9), são altos. Estas características geoquímicas diferem substancialmente das rochas calci-alcalinas típicas de zonas de subducção e granitóides tipo I na região.

Os padrões das curvas ETR normalizadas para condrito de (Boynton, 1984) (fig.6.7D), mostram ETRs extremamente fracionados, com valores altos em ETRL e muito depletados em ETRP, com anomalias de Eu negligenciáveis. O valor da razão $\mathrm{La}_{(\mathrm{n})} / \mathrm{Yb}_{(\mathrm{n})}$ apresenta razão é muito alto (9340) sugerindo alto grau de fracionamento. Nos spidergramas normalizados pelo manto primitivo (Sun e McDonough, 1989) (fig.6.7F) as rochas apresentam depleção em Rb, Nb, P e Ti, com valores próximos à unidade. Os diagramas discriminantes mais utilizados para distinção de rochas adakiticas $(\mathrm{La} / \mathrm{Yb})_{\mathrm{n}}$ vs. Yb , (Fig. 6.9A), (Martin, 1987, 1999) e Sr/Y vs Y de Defant and Drummond, (1990) classificam estas rochas como adakitos (Fig.6.9B). 

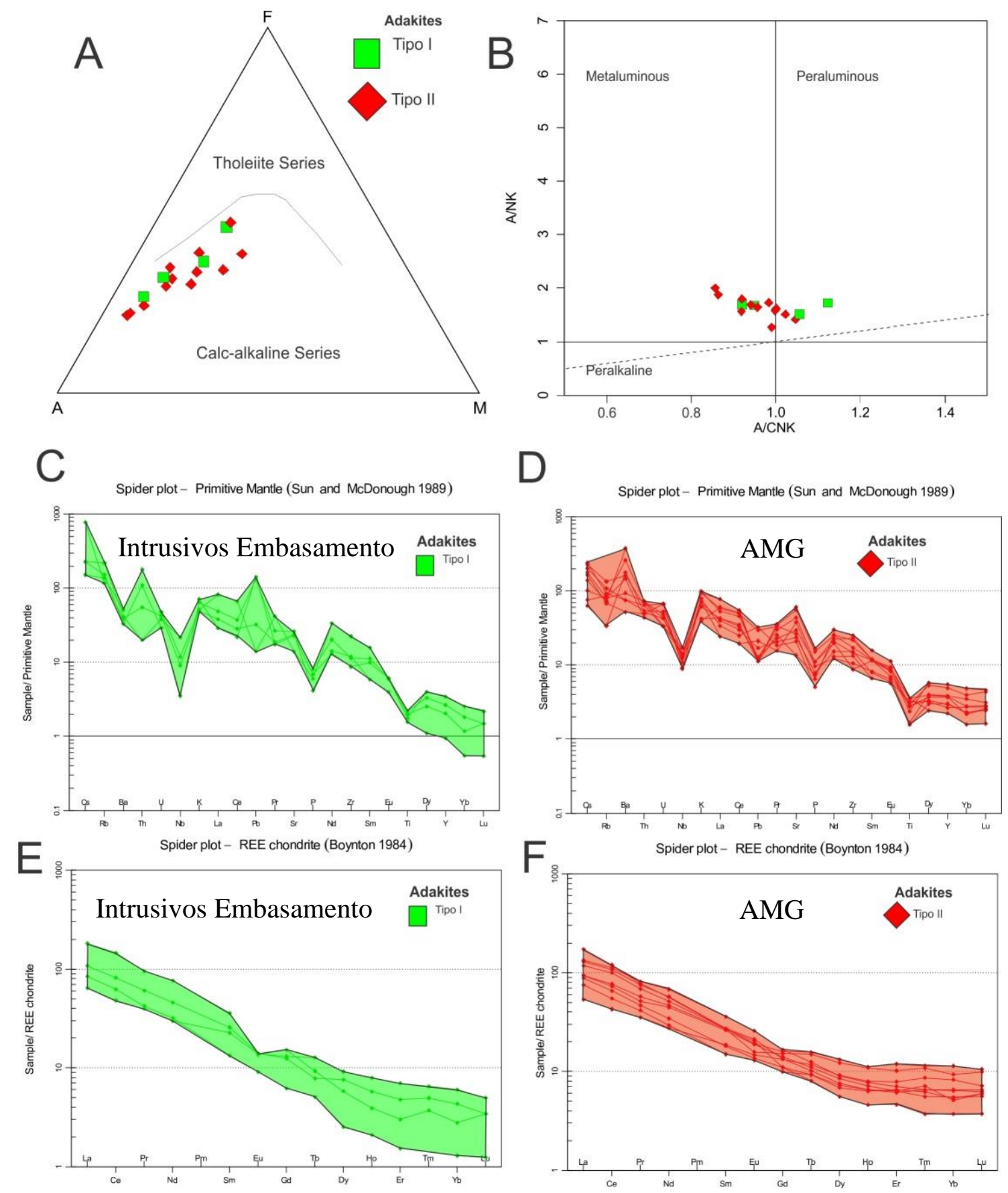

Fig. 6.7 - Classificação e curvas de elemento traço e ETR das rochas de tendência adakítica do AMG e intrusivas no embasamento. (Fig. 6.7A)- Diagramas AFM; (Irvine e Baragar, 1971), (Fig. 6.7B); Índice de Shand (Shand, 1943); (Fig. 6.7C e 6.7D) spidergramas normalizados pelo manto primitivo (Sun e McDonough, 1989), (fig.6.7E e 6.7F) padrões das curvas ETR normalizadas para condrito de (Boynton, 1984). 

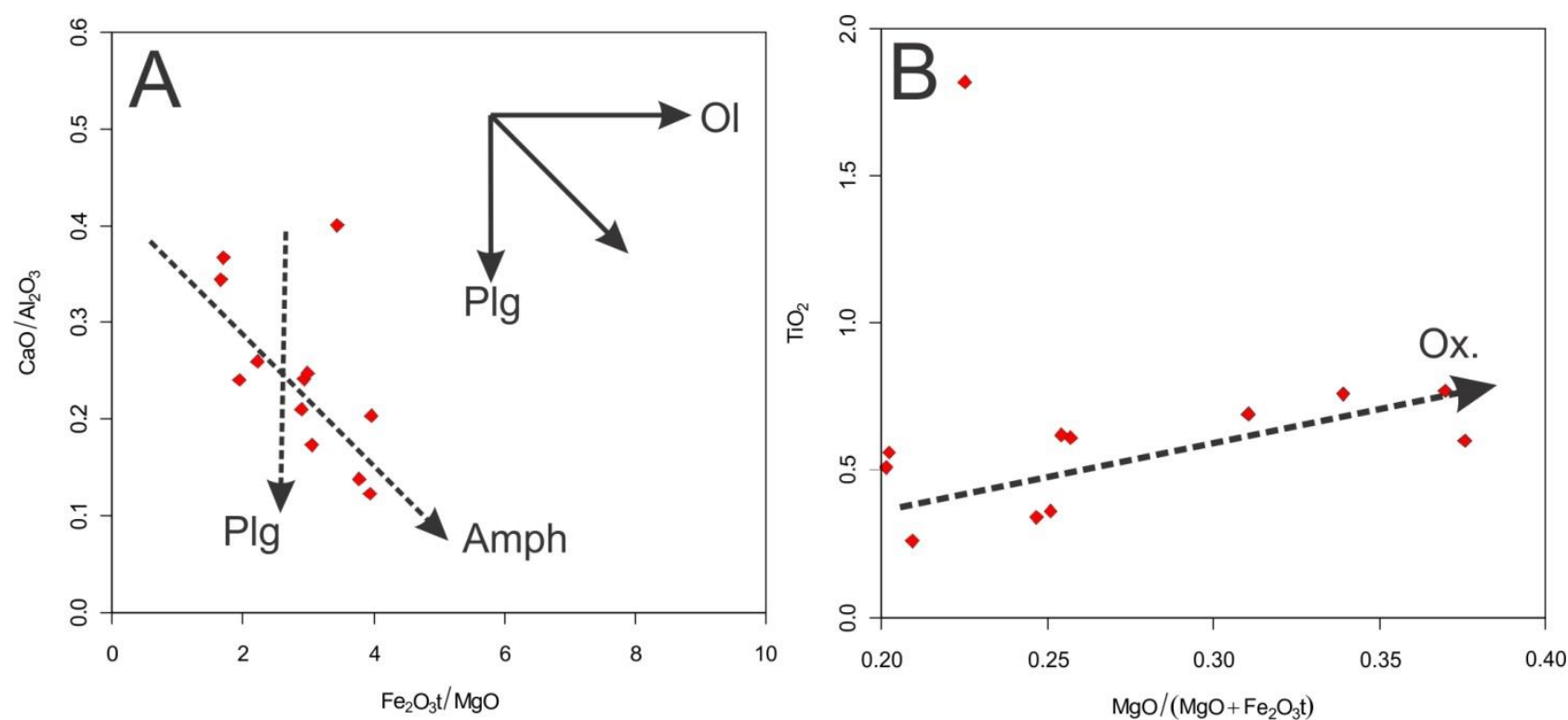

Fig. 6.8 - Diagramas indicativos de fracionamento mineral, a partir de elemento maiores nos grá-

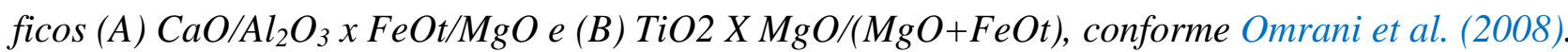
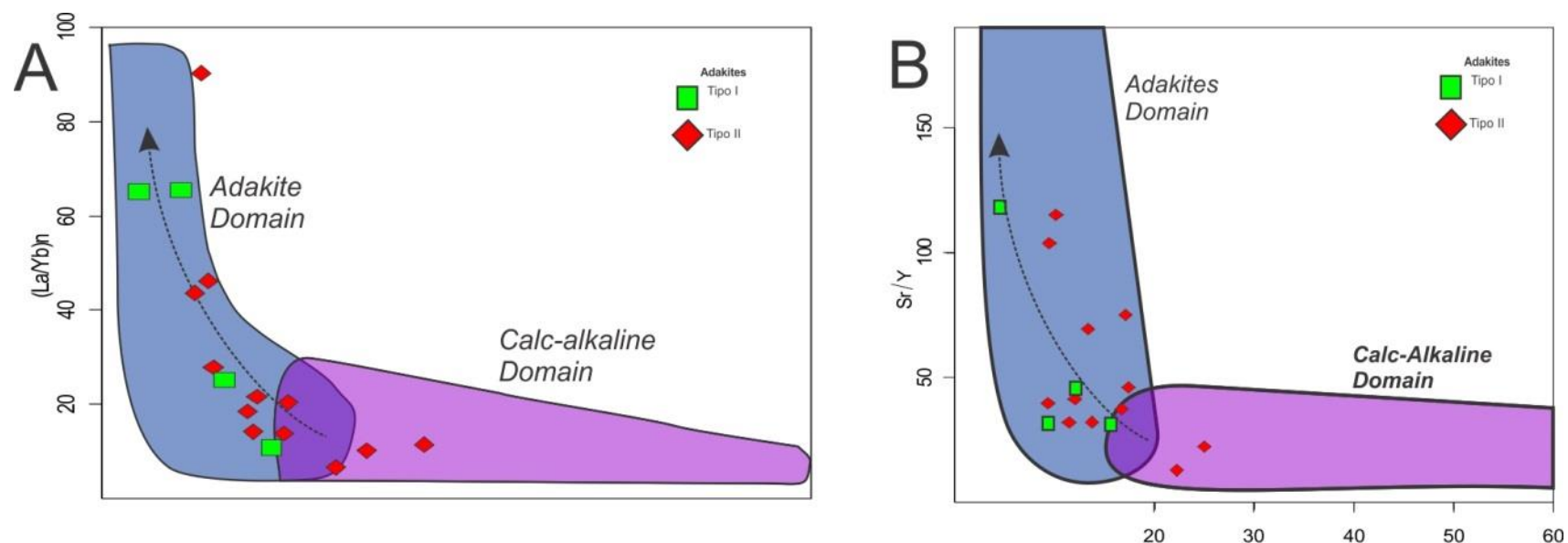

Fig. 6.9 - Diagramas distinção de rochas adakiticas $(\text { La/Yb })_{n}$ vs. Yb $b_{n}$, (Fig. 6.9A), (Martin, 1987, 1999) e Sr/Y vs Y de Drummond e Defant, (1990), (Fig. 6.9B). Para (n) padrão de normalização ao condrito de Boynton (1984).

A tabela 6.4 apresenta as principais características geoquímicas de rochas adakíticas e de tendência adakítica. Indica também as correntes de pesquisa quanto à origem dos magmas, se associados ao clássico conceito de fusões derivadas de uma placa oceânica quente e jovem em zona de subducção, ou a fusão parcial da crosta máfica inferior e orógenos em fase final. Os autores citados são referencias sobre assunto e os dados são comparados aos obtidos neste trabalho 


\begin{tabular}{|c|c|c|c|c|c|c|c|c|}
\hline \multicolumn{9}{|c|}{ Main geochemical features of adakite and like adakite rocks } \\
\hline \multirow{2}{*}{$\begin{array}{c}\text { Source } \\
\text { References }\end{array}$} & \multicolumn{4}{|c|}{ Partial Melting Lower Crust } & \multicolumn{3}{|c|}{ Slab Melt Derived - Subduccton } & \multirow[b]{2}{*}{ This Work } \\
\hline & Castillo (2006) & Guo et. al., (2007) & $\begin{array}{l}\text { Wang et. al., } \\
\text { (2006) }\end{array}$ & $\begin{array}{l}\text { Matteini et al., } \\
\quad(2002)\end{array}$ & $\begin{array}{c}\text { Drummond et al. } \\
\text { (1996) }\end{array}$ & $\begin{array}{c}\text { Defant and } \\
\text { Kepezhinskas (2001) }\end{array}$ & $\begin{array}{l}\text { Martin et al., } \\
\text { (2005) }\end{array}$ & \\
\hline high $\mathrm{SiO}_{2}$ & $\geq 56 \mathrm{wt} \%$ & 59-70 wt.\% & $57-70$ wt \% & $52-65.6$ wt $\%$ & $63.89 w t \%$ & $\geq 56 \mathrm{wt} \%$ & $>56 \mathrm{wt} \%$ & $58-70 w t \%$ \\
\hline high $\mathrm{Al}_{2} \mathrm{O}_{3}$ & $\geq 15 w t \%$ & $15-18$ wt.\% & $>15.4 \%$ & $14.8-17.1 \mathrm{wt} \%$ & $17.4 \mathrm{wt} \%$ & $\geq 15 w t \%$ & $>15 w t \%$ & $13-17 w t \%$ \\
\hline $\mathrm{Na2O}$ & & & $>4.06 \%$ & $3.5-4.8 \%$ & $4.40 \%$ & $>3.5 \%$ & $<3.5 \%$ & $3.55-5.51 w t \%$ \\
\hline $\mathrm{K} 2 \mathrm{O} / \mathrm{Na2O}$ & & & 0.56 & $0.3-0.7$ & 0.34 & $\underline{ }$ & 0.4 & 0.51 \\
\hline low MgO & $<3 w t \%$ & 1.3 to $3.0 \mathrm{wt} . \%$ & $<3.24$ wt $\%$ & $2.0-7.1 w t \%$ & $2.47 \%$ & & $<3 \% w t$ & $0.78-3.79 w t \%$ \\
\hline high Sr & $>300 \mathrm{ppm}$ & 317-1133 ppm & 645-1389 ppm & $703-1107$ ppm & $869 \mathrm{ppm}$ & $>400 \mathrm{ppm}$ & $>400 \mathrm{ppm}$ & $284-1284 \mathrm{ppm}$ \\
\hline Eu anomaly & no & 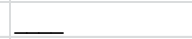 & no & no & 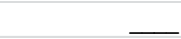 & 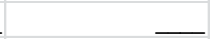 & no & No - Negligible \\
\hline $\operatorname{low} Y$ & $<15 \mathrm{ppm}$ & 4.2-12.9ppm & $<14.7 \mathrm{ppm}$ & 9-20 ppm & $9.5 \mathrm{ppm}$ & $<18 \mathrm{ppm}$ & $<18 \mathrm{ppm}$ & $13.67 \mathrm{ppm}$ \\
\hline high $\mathrm{Sr} / \mathrm{Y}$ & $>20$ & $44-162$ & $55-103$ & $33-81$ & 91 & $>40$ & $>40$ & 53.3 \\
\hline low Yb & $<1.9 \mathrm{ppm}$ & $0.3-0.9 \mathrm{ppm}$ & $<1.25 \mathrm{ppm}$ & $0.7-1.6 \mathrm{ppm}$ & $0.91 \mathrm{ppm}$ & $<1.9 \mathrm{ppm}$ & $<1.9 \mathrm{ppm}$ & $1.13 \mathrm{ppm}$ \\
\hline high La/Yb & $>20$ & 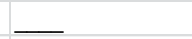 & 43.28 & $28-56$ & 19.28 & $>20$ & $>20$ & 45.42 \\
\hline HFSE's (Nb, Ta) & low & $\overline{\text { low }}$ & $\underline{-}$ &  & $\underline{-}$ & low & low & low \\
\hline low $87 \mathrm{Sr} / 86 \mathrm{Sr}$ & $<0.704$ & 0.704-0.709 & 0.706 & 0.706 & & & $\ldots$ & \\
\hline
\end{tabular}

Tabela 6.4- Principais características químicas de rochas adakiticas e referências.

\subsubsection{Geoquímica Isotópica Sm-Nd}

Os resultados isotópicos $\mathrm{Sm}-\mathrm{Nd}$ nas amostras estão na tabela 6.5. As rochas analisadas apresentam valores de $\mathrm{T}_{\mathrm{DM}}$ muito amplos que variam entre 3.38 e $0.96 \mathrm{Ga}$, e $\varepsilon_{\mathrm{Nd}}\left(\mathrm{T}_{0.58}\right)$ entre -31.54 e 0.6. Internamente observam-se dois grupos: Um mostra valores 3.38 e $1.75 \mathrm{Ga}$ de alta residência crustal e $\varepsilon_{\mathrm{Nd}}\left(\mathrm{T}_{0.58}\right)$ negativos entre -31.54 e -6.07. O segundo grupo apresenta valores de idades $\mathrm{T}_{\mathrm{DM}}$ entre 0.97 e $0.96 \mathrm{Ga}$ e $\varepsilon_{\mathrm{Nd}}\left(\mathrm{T}_{0.58}\right)$ entre -0.60 e -0.95 . Todas indicam fontes a partir de componentes crustais a parcialmente juvenis, com propensão aos de menor residência de apresentar fontes tendendo a valores de $\varepsilon_{\mathrm{Nd}}$ negativos e próximos a zero. $\mathrm{O}$ diagrama de evolução de $\mathrm{Nd}$ e representado na figura 6.10 .

Os dois conjuntos ocorrem em áreas distintas. Um correlaciona-se ao embasamento com influência do Maciço de Goiás indicando retrabalhamento de uma crosta continental arqueanapaleoproterozoica. O conjunto mais jovem está incluso no AMG, refletindo retrabalhamento crustal mais jovem e sugerindo influência e contaminação de crosta do arco intraoceânico Mara Rosa, retrabalhada no final do Neoproterozóico.

\subsubsection{Ambiente Tectônico}

A maior parte dos gráficos disponíveis na literatura sobre adakitos dá prioridade ao tratamento petrogenético, principalmente aos processos de geração de magma parental, a partir dos modelos são previstos os locais preferenciais para sua formação. Como as rochas adakíticas se correlacionam a ambientes orogênicos e se formam de magmas calci-alcalinos diferenciados, sua classificação segue os gráficos de interpretação tectônica usual, mas com uma questão ainda em aberto. 


\begin{tabular}{|c|c|c|c|c|c|c|c|c|c|c|c|c|}
\hline Sample & LAT & LONG & X_PROJ & Y_PROJ & Sm_ppm & Nd_ppm & $147 \mathrm{Sm} \_144 \mathrm{Nd}$ & 143Nd_144Nd_2SE & ENd_O & $\varepsilon N d_{-} t(0.58)$ & TDM & Source \\
\hline \multicolumn{13}{|c|}{ Adakites Like- Neoproterozoic } \\
\hline AF 048A & -11.04309318 & -48.58941258 & 763376 & 8778194 & 5.717 & 30.28 & 0.1141 & $0,511976+/-11$ & -12.91 & -6.69 & 1620 & Crustal \\
\hline AF 048B & -11.04309318 & -48.58941258 & 763376 & 8778194 & 11.473 & 53.74 & 0.1290 & $0,512061+/-11$ & -11.26 & -6.07 & 1750 & Crustal \\
\hline PV 70A & -12.41180247 & -48.74928588 & 744690 & 8626876 & 5.244 & 42.386 & 0.0748 & $0.512168+/-24$ & -9.16 & -0.60 & 960 & Crustal \\
\hline PV 70B & -12.41180247 & -48.74928588 & 744690 & 8626876 & 7.988 & 66.80 & 0.0723 & $0,512138+/-5$ & -9.74 & -0.95 & 970 & Crustal \\
\hline \multicolumn{13}{|c|}{ Adakites like - Basement Intruded } \\
\hline HL 141 & -11.6616858 & -48.1583159 & 809841 & 8709302 & 5.288 & 36438. & 0.0877 & $0.511076+/-17$ & -30.46 & -22.42 & 2370 & Crustal \\
\hline HL 052 & -11.72284838 & -48.08012710 & 818303 & 8702444 & 2.458 & 16.374 & 0.0907 & $0,510933+/-6$ & -33.26 & -25.44 & 2610 & Crustal \\
\hline LL 273A & -12.46930295 & -48.77651643 & 741675 & 8620538 & 5.126 & 28.642 & 0.1082 & $0.511461+/-15$ & -22.96 & -16.42 & 2270 & Crustal \\
\hline LL 278A & -12.0920262 & -48.51211359 & 770815 & 8662038 & 5.273 & 27.842 & 0.1145 & $0.511519+/-13$ & -21.82 & -15.73 & 2330 & Crustal \\
\hline LM 204 & -13.897262 & -49.880214 & 620987 & 8463352 & 2.771 & 15.721 & 0.1066 & 0,510681+/-15 & -38.17 & -31.54 & 3380 & Crustal \\
\hline
\end{tabular}

Tabela 6.5 - Dados Isotópicos Sm-Nd para rochas adakiticas do Domínio do Arco Magmático de Goiás e das intrusivas no embasamento.

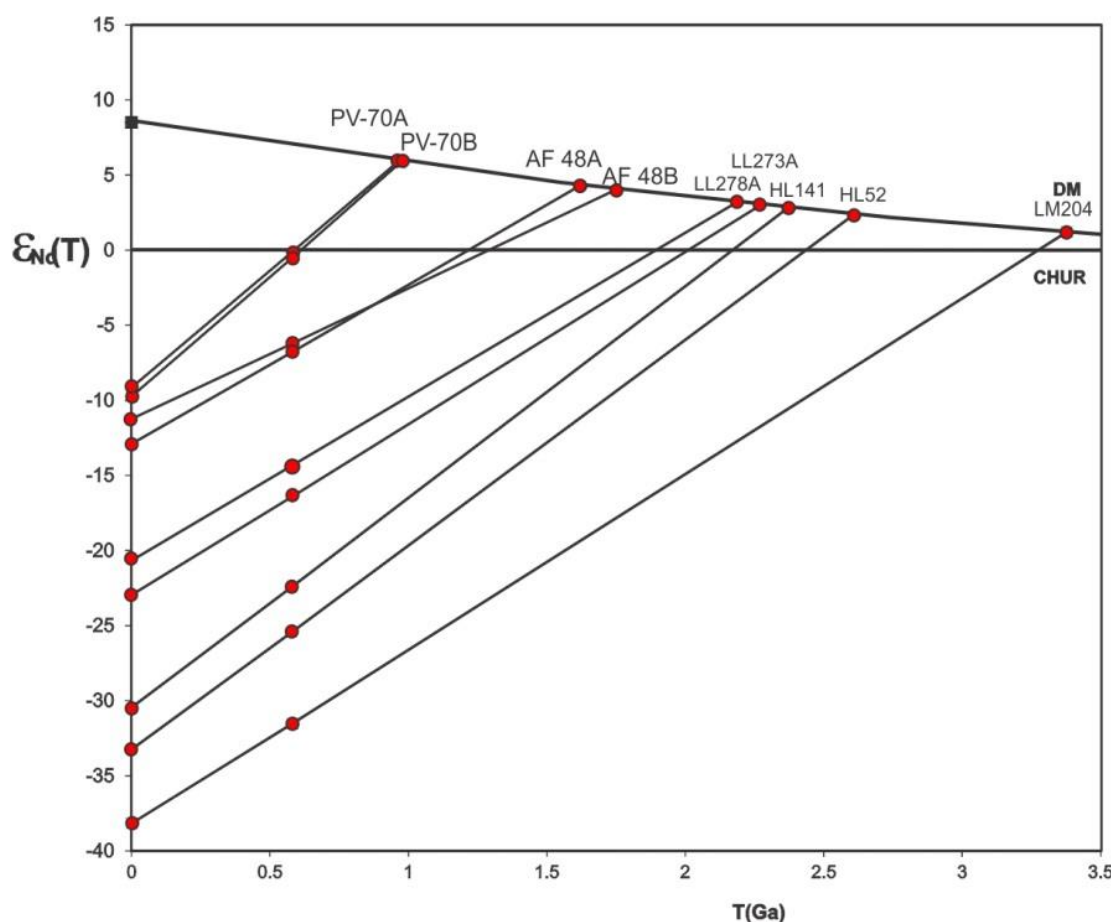

Fig. 6.10 - Diagrama de evolução isotópica Nd para os adakitos do Arco Magmático de Goiás (A); e de embasamento (B); calculadas para $\varepsilon N d T(0.58 \mathrm{Ga})$.

Um limitador à utilização dos gráficos de classificações tectônicas em rochas adakiticas baseia-se no fato de que grande parte dos diagramas discriminantes se apoia em elementos traço como $\mathrm{Rb}, \mathrm{Y}$ e $\mathrm{Yb}$, justamente os dois elementos que caracterizam as baixas razões $\mathrm{Sr} / \mathrm{Y}$ e La/Yb dos adakitos, apresentando-se nestas rochas em concentrações menores. Grande parte dos diagramas baseados nestes elementos faz com que os pontos de análise sejam deslocados nos campos tectônicos. $\mathrm{O}$ exemplo mais típico, neste caso, é quando adakitos relacionados a eventos pós-colisionais sejam deslocados para campos eminentemente sin-orogênicos. 
Todavia, o diagrama R1-R2 de Batchelor and Bowden (1985), baseado em elementos maiores dá uma noção melhor da classificação destas rochas. Tanto os adakitos internos ao AMG (losangos vermelhos) como os intrusivos no embasamento (quadrados verdes), apresentam tendência ao campo pós-colisiona (Fig.6.11A). Esta tendência tem suporte nos dados U-Pb apresentados, em especial, no caso dos adakitos de idade U-Pb em torno de 554 - $540 \mathrm{Ma}$, correspondente à idade de fechamento do orógenos Brasília e Araguaia na porção setentrional da Província Tocantins. O diagrama de Schandl \& Gorton (2002), (Fig.6.11B) para razão de elementos traço Th/Yb vs. Ta/Yb plota as amostra no campo de geração em margens continentais ativas.
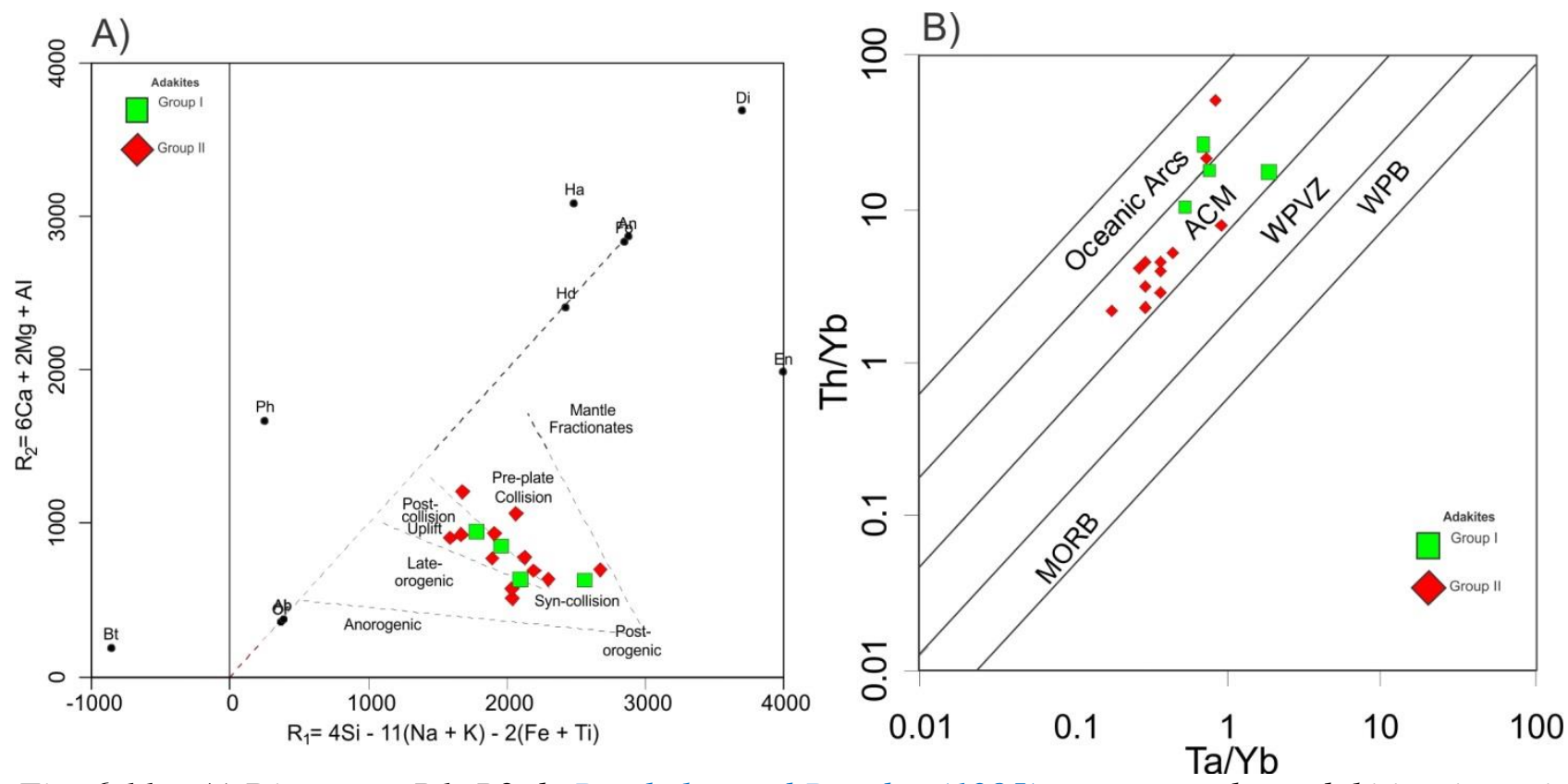

Fig. 6.11 - A) Diagrama R1-R2 de Batchelor and Bowden (1985) para as rochas adakiticasintrusivas nos arcos neoproterozoicos (Vermelho) e no embasamento paleoproterozoicas (verde) sobrepõem os campos dos granitoides post-collision uplift field. $R 1=4 S i-11(\mathrm{Na}+\mathrm{K})-2(\mathrm{Fe}+\mathrm{Ti})$; $R 2=6 C a+2 M g+A l . B)$ Diagrama de Th/Yb vs. Ta/Yb de Schandl \& Gorton (2002). ACM -Active Continental Margin.

\subsection{Discussão}

\subsubsection{Aspectos Petrogenéticos}

À primeira vista os dados de composição petrográfica de gnaisses tonalíticos e granodioritícos, associados aos resultados da litoquímica de elementos maiores, traços e ETRs indicariam tratar-se de rochas de trend calci alcalinas normal, com padrões de curvas ETR fracionados e spidergramas com proeminentes anomalias de $\mathrm{Nb}, \mathrm{P}$ e Ti formadas a partir de processos de subducção. 
Esta interpretação seguiria seu curso natural se outras características não fossem ressaltadas como os altos teores em $\mathrm{Na}_{2} \mathrm{O}$, baixo peso molecular de $\mathrm{MgO}$, baixa razão $\mathrm{K}_{2} \mathrm{O} / \mathrm{Na} 2 \mathrm{O}$, altas concentrações de $(\mathrm{Sr}>550 \mathrm{ppm})$ e La (> $36 \mathrm{ppm})$, falta de anomalia de Eu, baixas concentrações de $\mathrm{Y}$ $(<15 \mathrm{ppm}), \mathrm{Yb}(<1.2 \mathrm{ppm})$ e HFSE. Todas estas peculiaridades são típicas e apontam para uma tendência adakítica das rochas estudadas.

Condie (2005) compara os adakitos na Cordilheira dos Andes, em sua porção extrema sul, com os adakitos formados na posição central dos Andes. Os adakitos do sul dos Andes relacionamse a formação de adakitos clássicos em zonas de subducção derivados de fusão de uma crosta jovem e quente e apresentam valores altos de $\mathrm{Sr}, \mathrm{\# g}$, Ni e Cr. Na posição central vulcânica dos Andes ocorre o inverso, com a formação de adakitos com baixo teores de \#Mg, Sr, Ni e Cr. A diferença envolve a geração do magma que na posição central dos Andes esta relacionada a uma crosta espessada, sob forte encurtamento tectônico e envolve processos de delaminação litosférica.

O gráfico \#Mg vs $\mathrm{SiO}_{2}$, (Fig.6.12A) indica condições similares aos produtos de delaminação litosférica, com geração de magmas na base da crosta deixando como resíduo composição eclogíticas. Estes magmas formados são similares às fusões experimentais de rochas máficas hidratadas e explicam os baixos valores encontrados em \#Mg, Cr, Ni e com valores semelhantes às amostras estudadas.

Outro motivo são os baixos valores em \#Mg que se devem pela baixa concentração de $\mathrm{MgO}<3 \%$ em peso na razão, confirmada pelos valores baixos de $\mathrm{Cr}$ e $\mathrm{Ni}$, mas ainda anômalos para rochas adakiticas. Na Fig.6.12A é possível ver a propensão ao campo adakitico, principalmente para as rochas neoproterozoicas, do grupo II (losangos vermelhos) em relação às do grupo I, com coeficiente de assimilação e cristalização fracionada abaixo de 5\% e com fusão primária não derivada do manto peridotítico conforme proposto por Castillo (2006).

No gráfico Nb/Ta vs Zr/Sm, (Foley et al., 2002, Fig.6.12B) observa-se a tendência das rochas adakiticas a se agruparem em valores altos da razão $\mathrm{Nb} / \mathrm{Ta}$, na maioria $>15$ e $<22$ e a se localizarem em proporções próximas à linha do manto primitivo. O gráfico apresenta os campos de fusão de rutilo eclogito e anfibolito e hornblenda eclogito. Ambos os gráficos mostram de forma preliminar o baixo coeficiente de fusão e o tipo de crosta envolvido na geração destas rochas.

Os gráficos da figura 6.13 caracterizam e corroboram a gênese das rochas. A figura 6.13(A) apresenta o diagrama para as rochas adakiticas $(\mathrm{La} / \mathrm{Yb})_{\mathrm{n}} \mathrm{vs.} \mathrm{Yb}_{\mathrm{n}}$, (Martin, 1987, 1999), modificado, Karsli et al, (2011) observam o campo adakitico ocupado pelas amostras entre curvas de fusão (linhas azuis), com a tendência das amostras em acompanhar as linhas em torno de $3 \%$ de melt ou pouco acima em direção ao campo granada-anfibolito, coerente com os dados apresentados na fig. $6.12(\mathrm{~A})$ e $(\mathrm{B})$. 

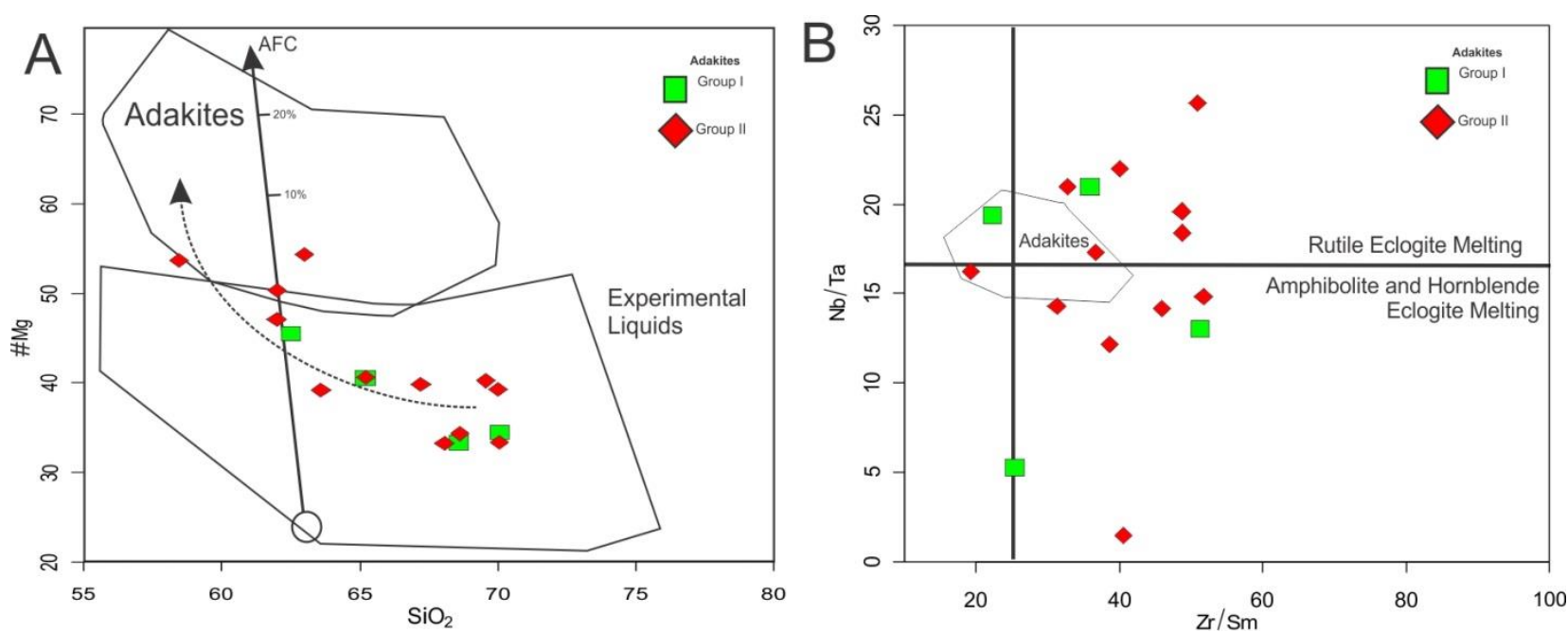

Fig. 6.12 - (A) - Gráfico \#Mg vs $\mathrm{SiO}_{2}$ (Condie, 2005), comparando os adakitos Grupo II (losangos vermelhos) posicionados no arco com os intrusivos em áreas do embasamento Grupo I(quadrados verdes), Campo dos líquidos experimentais de Rapp et al., (1991) e Winter (1996). AFC - Trajetória assimilation and fractional crystallization de Stern e Kilian (1996), com os percentuais de rochas ultramáficas assimiladas. (B) - gráfico Nb/Ta vs Zr/Sm, (Foley et al., 2002) para adakitos da porção setentrional do Orógeno Brasília, arco e embasamento.

O diagrama da fig. 6.13(B) (Sr/Y vs. La/Yb, (Moyen 2009) mostra os modelos de fusão e interações do manto, para rochas adakiticas. Os plots, tanto do arco jovem (losangos vermelhos), como os intrusivos no embasamento (quadrados verdes) sobrepõem a área de mistura manto-adakito (MAM) utilizado no modelo, bem com os campos dos adakitos arqueanos (AA) e dos adakitos de alta sílica (HSA). As rochas seguem a linha de fusão em alta pressão dos adakitos tipo HSA (alta sílica) deixando no resíduo anfibólio-granada. O resultado é idêntico ou semelhante aos demais diagramas e indicam profundidades superiores a $40 \mathrm{~km}$.

O diagrama da figura 6.13(C) de Moyen (2009) é uma variante do gráfico Sr/Y determinantes dos campos de classificação e fontes de geração. Neste gráfico as amostras todas estão no campo dos TTGs, e localizadas dentro ou em torno do campo dos HSA, para razões superiores de $\mathrm{Sr} / \mathrm{Y}>40$, conforme calculado para amostras (em média superiores a 50) e ainda indicativas de fusão de rochas máficas sob alta pressão com $\mathrm{Cpx}+\mathrm{Anf}+\mathrm{Grd}$ no resíduo e baixas taxas de fusão, inferiores a $5 \%$.

Em todos os gráficos o modelo proposto de fonte para os adakitos neoproterozóicos do grupo II é mais consistente, pela quantidade e agrupamento dos pontos, a fusões em base de crosta. Os adakitos do grupo I mostram-se mais espalhados sugerindo que tenham origem e fusões distintas. 



Fig. 6.13 - (A) Diagrama índice de La/Yb vs. Yb normalizado ao condrito. Campos de adakite e TTG de rochas calci-alcalinas de arco, Martin (1999), Karsli et al. (2011). A amostra de gabro G518 (Dokuz et al., 2006) foi utilizada como fonte ETR para modelagem nas condições de equilíbrio entre anfibolito e eclogito, com diferentes conteúdos de granada e respectivos coeficientes de partição propostos por (Irving e Frey 1978; Fujimaki et al., 1984 e Sisson, 1994). (B) Diagrama de Moyen (2009) Sr/Y vs. La/Yb: Adakitos Alta $\mathrm{SiO}_{2} \mathrm{HSA}$ (preto), Adakitos Baixa $\mathrm{SiO}_{2}$ (LSA cinza), Adakites Arqueano (AA), TTG e granitos normais ("S e I"). MORB representa a extremidade "Caminho do manto", (PRIM) indica a composição do manto primitivo, (CH) condrito; (DMM) manto empobrecido CC e UCC são as composições da massa e crosta continental superior, respectivamente (Taylor e McLennan, 1985). MAM é o mix do manto-adakite utilizado nos modelos de intera- 
ção manto. Curva de fusão "Máficas baixo $P^{\prime \prime}=$ baixa pressão (10 kbar) fusão de anfibolito com residuum granada-plagioclase;"Máfica alta $P$ "= 20 kbar fusão de fonte semelhante, gerando HSA. (C) gráfico $\mathrm{Sr} / Y$ com modelos de fusão e de interações com o manto. Símbolos e abreviações como na Fig. 6.13(B).

\subsubsection{Natureza da Região e Fonte dos Magmas Adakiticos}

As rochas adakiticas estudadas possuem índices de Shand mistos, de metaluminosos a peraluminosos (fig. 6.7B), em contraste com rochas geradas em zonas de subducção, cuja tendência é ser metaluminosa. Os valores moderados a baixos de \#Mg (54-33, em média 42), Ni (média 16.2 ppm), conteúdo enriquecido em Th, observados nos spidergramas da fig. 6.7, tanto para os adakitos intrusivos no embasamento, como principalmente, para as rochas mais jovens com valores de $\varepsilon_{\mathrm{Nd}}$ negativos e crustais, e idades $\mathrm{U}-\mathrm{Pb}$ ediacaranas, fazem com que estas rochas difiram acentuadamente em características acentuadamente dos adakitos derivados de uma zona de subducção e argumentam para uma origem diversa.

As figuras 6.14(A) e 6.14(B) representam os binários Th/U vs. U e Th/U vs Th. Os gráficos pode-se permitem avaliar que as razões $\mathrm{Th} / \mathrm{U}$ são relativamente moderadas a altas, entre 5 e 10 indicando-as como produtos de fusões produzidas na base da crosta continental (Rudnick \& Gao, 2003; Karsli et al., 2011). Grande parte das amostras aproxima-se do campo LCC (Lower Continental Crust). Os corpos representam uma exposição crustal profunda do AMG na região e geralmente encontram-se associados ou em adjacência com corpos granulíticos.

A figura 6.14C apresenta o binário simples $\mathrm{MgO} \times \mathrm{SiO}_{2}$. Apesar da dispersão de dados os maiores conjuntos são associados a produtos de fusão de uma crosta espessada ou alternativamente como derivados de delaminação da crosta inferior. A fig. 6.14D com as razões $\mathrm{Al}_{2} \mathrm{O}_{3} / \mathrm{FeO}+\mathrm{MgO}+\mathrm{TiO}_{2}$ vs. $\mathrm{Al}_{2} \mathrm{O}_{3} /+\mathrm{FeO}+\mathrm{MgO}+\mathrm{TiO}_{2}$ aponta para derivação de rochas anfibolíticas + hornblenda eclogitos, levando a inferir grande profundidade e pressão elevada, confirmada nas razões $\mathrm{Nb} / \mathrm{Ta} \mathrm{Vs}$. $\mathrm{Zr} / \mathrm{Sm}$ da fig. 6.12B, onde as amostras se dividem entre os dois campos. 



Fig. 6.14- (A) e (B) Diagramas Th/U vs. $U$ e(b) Th/U versus Th para amostras de adakitos. Campos LCC, (lower continental crust); MCC, (middle continental crust). Composição da crosta continental inferior e intermediária sesundo Rudnick and Gao (2003). O MORB de Sun et al. (2008). (C) Diagrama $\mathrm{MgO}$ vs. $\mathrm{SiO}_{2}$ para as amostras estudadas. Campos dos adakitos produzidos por fusão de placas oceânicas, por delaminação da crosta inferior, fundidos metabasalticos e eclogitos experimentais (1-4,0 GPa) de Wang et al. (2006), e adakitos formados por fusão parcial de crosta máfica inferior espessada (Atherton e Petford, 1993; Chung et al., 2003; Johnson et al., 1997; Muir et al., 1995; Petford e Atherton, 1996; Wang et al., 2005, Karsli et al., 2011) e referências. D) Diagrama $\mathrm{Al}_{2} \mathrm{O}_{3} / \mathrm{FeO}+\mathrm{MgO}+\mathrm{TiO}_{2}$ vs. $\mathrm{Al}_{2} \mathrm{O}_{3} /+\mathrm{FeO}+\mathrm{MgO}+\mathrm{TiO}_{2}$ para composições adakiticas e campos composicionais experimentais de fusões parciais derivadas de metapelitos, metagrauvacas e anfibolitos, todos os gráficos expostos e referenciados em Karsli et al., (2011).

\subsubsection{Significado Tectônico}

A evidência (a) química e petrológica relatada, (b) o posicionamento geotectônico de plútons sincinemáticos tonalíticos e granodioríticos gnáissicos inseridos em áreas de alto grau e 
metamorfismo anfibolitico e em proximidade e adjacência às zonas granuliticas associadas ao Lineamento Transbrasiliano; (c) as idades e dados isotópicos $\mathrm{Sm}-\mathrm{Nd}$ com variações heterogêneas de $\mathrm{T}_{\mathrm{DM}}$ desde 970 a $1750 \mathrm{Ma}$, e $\varepsilon_{N d}$ de -0.6 a -6.69 , marcam a contribuição crustal. A idade U-Pb em zircão de 590-550 Ma, combinada com demais dados regionais, sugere que estes adakitos relacionam-se a fusão parcial na base da crosta continental máfica durante ou préviamente ao processo de delaminação do Orógeno Brasília, no Arco de Santa Terezinha de Goiás em seu instante póscolisional, fechamento de arco e encerramento de magmas gerados em zonas de subducção. O significado maior é que estas rochas balizariam o instante em que as placas Amazônica e São FranciscoCongo colidem no W-Gondwana, com delaminação de sua parte inferior. A abertura causada pela perda de massa inferior abaixo do arco é descrita e comprovada por dados geofísicos. Estudos de refração sísmica (Soares et al., 2006) e gravimetria apontam anomalia Bouguer positiva e anomalia magnética profunda (Assumpção et al., 2004; Feng et al., 2007) que é explicada como uma densa litosfera mantélica subjacente ao arco magmático, onde a crosta tem apenas $36-38 \mathrm{~km}$ de espessura. Esta posição poderia marcar exatamente a zona de delaminação e onde a porção inferior da crosta foi perdida e/ou afinada com ocupação pela astenosfera. Para leste, a espessura da crosta aumenta até 43 km abaixo da zona externa do Orógeno Brasília e parte do Cráton do São Francisco; a oeste, sob o gradiente da anomalia gravimétrica, dados de função do receptor mostram que a crosta pode atingir $53 \mathrm{~km}$ de espessura (Trindade et al., 2014). A estrutura é considerada o resultado da duplicação da parte inferior da paleoplaca Amazônica durante o final da subducção neoproterozóica abaixo do Arco Magmático de Goiás (Ventura et al., 2011). Modelo representativo é exposto na figura 6.15

Todavia, fazem-se duas reservas: (a) este modelo é apenas da parcela das rochas adakiticas encontradas na região e nesta representação apenas leva em consideração os adakitos neoproterozóicos com idades ediacaranas. $\mathrm{O}$ entendimento das rochas com características similares observadas no embasamento não está contemplado; $(b)$ não se exclui a possibilidade de haver adakitos tonianos, relacionados a zonas de subducção e pertencentes ao Arco de Mara Rosa.

As ponderações a favor dos processos de delaminação se reforçam ainda com a idade obtida para o evento transpressional obtidas por Frasca et al., (2015), que são pós evento colisional e compativeis com a idade dos granulitos em torno de 594 2 Ma. Registra-se também o evento astenosférico marcado por rochas máficas gabro anfiboliticas (TA20 - apêndix I) relacionadas ao evento tardio pós-colisional e apresentam idade U-Pb 578 $\underline{6}$ Ma e $\mathrm{T}_{\mathrm{DM}}$ entre $1,49 \mathrm{Ga}$ e 0.82 com $\varepsilon_{\mathrm{Nd}(\mathrm{T} 580)}$ mistos de +4.26 a -1.11 , marcando contribuições juvenis e interações de crosta no período de rompimento litosférico. 

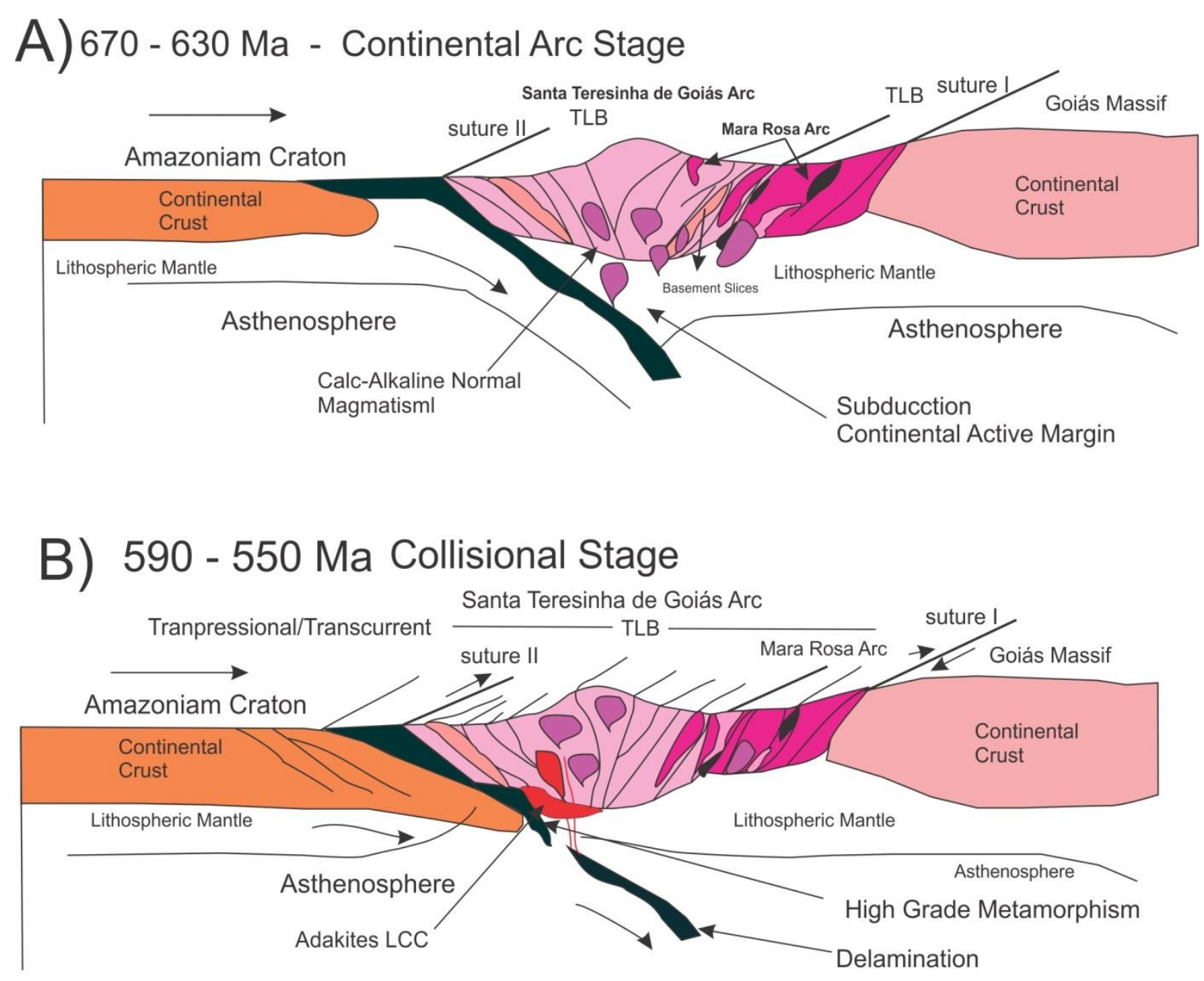

C) 550 - 528 Ma Orogen Closure

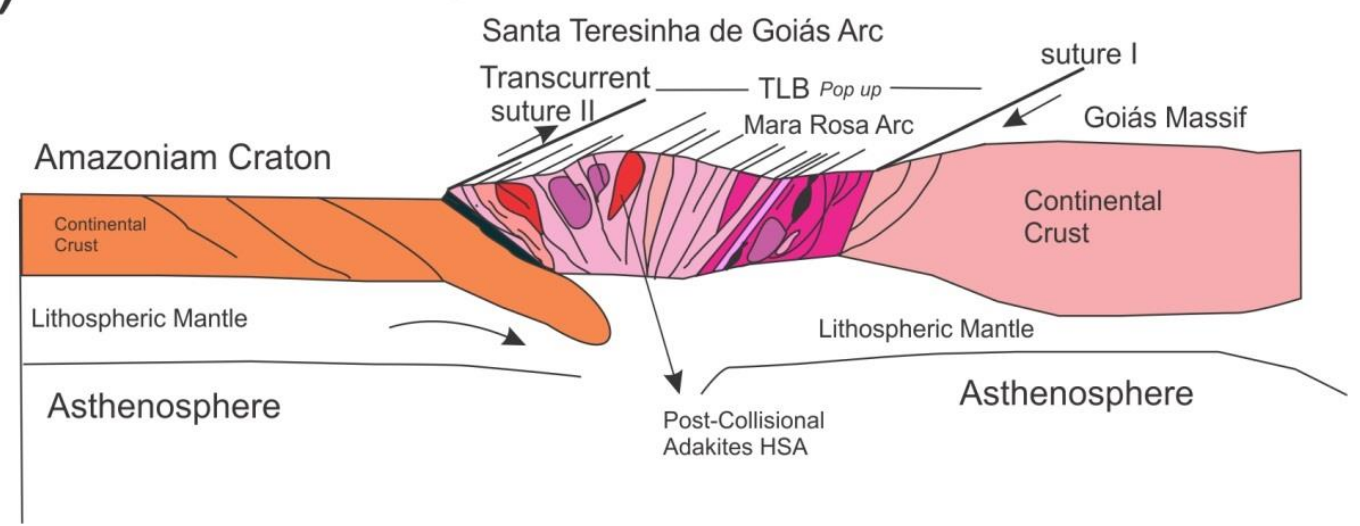

Fig. 6.15 - Modelo para geração dos adakitos em estágio pós-colisional. A) Estágio arcocontinente com magmatismo calci-alcalino normal associado à subducção de crosta oceânica (Complexo Quatipuru); B) Início do processo de rompimento de crosta, delaminação, aumento de temperatura e fusão parcial da crosta inferior máfica (LCC, Lower Continental Crust), derivação de rochas anfibolíticas + hornblenda eclogitos, limite da zona de fusão rutilo eclogito com geração de adakitos $\mathrm{HSA}$, ricos em ETRL, $\mathrm{Sr}$, pobres em $\mathrm{Ni}$; C) continuidade de processos deformacionais 
compressivos e transcorrentes e colocação dos corpos em níveis crustais superiores, fechamento e colisão.

Além destas considerações outras questões ainda ficam em aberto para estudos futuros: fica a ideia que a mudança do magmatismo de calci-alcalino normal (670-630 Ma) para adakitico (590 $550 \mathrm{Ma}$ ) ao longo de mais $300 \mathrm{~km}$ estaria relacionada à zona de subducção do arco continental de Santa Terezinha de Goiás e limitada às janelas de break-off da placa subjacente no limite da crosta continental máfica inferior. Desta forma, as quebras estariam relacionadas à mudança de ângulo da placa subjacente e esforços diferenciados, frente a crostas e blocos do embasamento (Maciço de Goiás e outros blocos alóctones à sua frente a leste), ou haveria zonas de subducção distintas, com o fechamento do orógeno não diacrônico, encerrando um a sul e central em 630 Ma marcado no pico metamórfico granulítico e outro mais tarde, cerca de 50 Ma após, na porção norte.

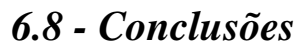

$\mathrm{Na}$ porção setentrional do Orógeno Brasília são encontrados tonalitos e granodioritos de forte tendência adakitica. As ocorrências estão dispersas em vários plútons e corpos isolados e estirados ao longo de centenas de quilômetros.

São separados dois grupos pela forma e local de intrusão. O grupo identificado como de tendência adakítica que ocorre dentro de áreas com o contexto geológico do embasamento e apresen$\operatorname{tam} \mathrm{T}_{\mathrm{DM}} 3.38$ e $1.75 \mathrm{Ga}$ de alta residência crustal e $\varepsilon_{\mathrm{Nd}}\left(\mathrm{T}_{0.58}\right)$ negativos entre -31.54 e -6.07 . Um segundo grupo e mais numeroso possui valores de idades $\mathrm{T}_{\mathrm{DM}}$ entre 0.97 e $0.96 \mathrm{Ga}$ e $\varepsilon_{\mathrm{Nd}}\left(\mathrm{T}_{0.58}\right)$ entre -0.60 e -0.95 de derivação crustal. Datação U-Pb em zircão apontam idades de 590-554 Ma.

Todos os grupos estudados atendem os requisitos para classificação química de adakitos HSA (Alta $\mathrm{SiO}_{2}$ ), em geral todos possuem, alto $\mathrm{Na}_{2} \mathrm{O}>4 \%$, baixas razões $\mathrm{K}_{2} \mathrm{O} / \mathrm{Na}_{2} \mathrm{O}<0.5$, curvas de ETR muito fracionadas, sem anomalias de $\mathrm{Eu}$, alto $\mathrm{Sr}(>631 \mathrm{ppm})$, baixo $\mathrm{MgO} \%$ (<1.8, baixo), Y (<13 ppm), alta razão $\mathrm{Sr} / \mathrm{Y}>30$ e $>50$ (média), $\mathrm{Yb}(<1.13 \mathrm{ppm})$, alta razão $\mathrm{La} / \mathrm{Yb}(>45)$ e (La)n/(Yb)n (>30), baixo HFSE, como $\mathrm{Nb}<8$ ppm (média), Ta<0.5 ppm (média). Comparados às demais ocorrências de adakitos mundiais em ambientes pós-colisão os dados apresentados indicam uma correlação satisfatória.

O contexto geotectônico aponta para rochas formadas em ambiente pós-colisional. A ênfase dada ao grupo neoproterozóico e sua idade entre 590-554 Ma é coerente com o estágio tardio, pós colisional do Arco de Santa Terezinha de Goiás, prolongando a atividade do arco por mais tempo.. 
Os dados químicos sugerem fusão primária parcial abaixo de $5 \%$ na base da crosta máfica continental entre os campos de rutilo eclogito e anfibolito-hornblenda eclogito com anfibolito-Cpxgranada-plagioclásio no resíduo. Em todas as hipóteses a profundidade de geração é superior a 40 $\mathrm{km}$.

A proposta de derivação das rochas como produtos relacionados a delaminação e fusão da crosta inferior, no final do Neoproterozóica parece ser a mais razoável, pois classifica, conforme indicado pela ambientação geotectônica os adakitos HSA como de contexto pós-colisional e concordantes com dados geofísicos que apontam anomalias positiva Bouguer e espessuras mais finas da crosta sob o arco.

A ocorrência dos adakitos marca, por sua vez, a proximidade da zona de sutura crustal que estaria a oeste e geometricamente paralela ao limite dos corpos. A linha de rochas adakiticas baliza em outras palavras a fronteira de delaminação litosférica do arco continental ocorrida no período entre 590-550 Ma no Arco Magmático de Goiás setentrional. A significância deste magmatismo adakíticos, abre uma nova expectativa prática a metalogenia e o mapeamento de setores tectônicos de arco, fornece uma perspectiva na evolução e quimismo do Orógeno Brasília e ao fechamento dos orógenos que levaram à formação de W-Gondwana. 


\section{Capítulo 7 - Conclusão}

O papel da tectônica de placas na Província Tocantins, segmento do W-Gondwana, é evidenciado pela formação de arcos magmáticos acrescionários confirmada pelas assembleias petrotectônicas, natureza da deformação, pelos dados litogeoquímicos e significado isotópico do magmatismo

Os dados alcançados na porção setentrional do Orógeno Brasília e sua justaposição à porção sul do Orógeno Araguaia, ao longo da sutura do Lineamento Transbrasiliano confirmam a extensão do Arco Magmático de Goiás, conforme já havia sido previsto anteriormente (Pimentel \& Fuck ,1992; Junges et al., 2002; Laux et al., 2005); Dantas et al., 2007; Fuck et al., 2014), compartimentados e representados pelo Arco de Mara Rosa e Arco Santa Teresinha de Goiás.

Identifica-se o embasamento paleoproterozóico representados pelo Maciço de Goiás, os granulitos do Complexo Porto Nacional e o Complexo Rio dos Mangues que possuem características litológicas, químicas, idades e similaridades isotópicas, posicionado-se em ambos os lados do LTB, tanto no orógeno Brasília, como no Araguaia. As idades U-Pb em zircão são próximas a $2.1 \mathrm{Ga}, \varepsilon_{\mathrm{Nd}}$ +3.69 e +1.11 indicam a presença de rochas juvenis com $\mathrm{T}_{\mathrm{DM}}$ entre 2300 a 2060 Ma e também, um importante evento de retrabalhamento crustal marcado $\varepsilon_{\mathrm{Nd}}-16.17$ e -0.01 com $\mathrm{T}_{\mathrm{DM}}$ entre 2980 a $1950 \mathrm{Ma}$, com representatividade maior de idades modelo arqueanas no Bloco CavalcanteNatividade.

É distinguido no AMG e incluso ao LTB acresções com fontes juvenis típicas de arcos de ilhas e relacionadas ao Arco de Mara Rosa, atuando entre 900 e 800 Ma. Esta associação posicionase a oeste da Falha do Rio dos Bois e amoldando-se ao Lineamento Transbrasiliano e sugere uma primeira zona de sutura entre arco e seu embasamento.

$\mathrm{O}$ arco intra-oceânico caracteriza-se por rochas calci-alcalinas intermediária a ácidas, metaluminosas e com valores de $\mathrm{SiO}_{2}$ baixos em torno de $59.67 \%$ e valores de $\mathrm{CaO}$ acima de $6.00 \%$ e de baixos teores em $\mathrm{K}_{2} \mathrm{O}$ de $1.17 \%$, com razões $\mathrm{K}_{2} \mathrm{O} / \mathrm{Na}_{2} \mathrm{O}$ com valores próximos de 0.28 , baixo LILE e HFSE. Apresentam padrões de ETR com baixos a moderados valores em ETRL e depletadas em ETRP com baixo fracionamento, sem dispersão nos valores de ETRP, mostrando uma fonte geradora comum. Idades de cristalização são de $848 \mathrm{Ma}$ e $810 \mathrm{Ma}$, com $\mathrm{T}_{\mathrm{DM}}$ de 1480 a $910 \mathrm{Ma}$ e $\varepsilon \mathrm{Nd}_{(\mathrm{T} 840)}$ com valores de $+1.56 \mathrm{a}+5.14$, indicando fontes juvenis

Uma segunda fase acrescionária, tardia e não progressiva em relação a anterior, sugere o desenvolvimento de uma margem continental ativa em 670-660 Ma, marcada por uma associação de rochas plutônicas de arco, sua assinatura química e isotópica com o aumento de fontes mistas, 
juvenis e crustais. $\mathrm{O}$ evento mais representativo é o magmatismo ediacarano, que iniciou em torno de 590 Ma, estendendo-se até 540 Ma. Forma um arco magmático de margem ativa, até sua maturidade. Este arco é a continuidade e coalescência tectônica do Arco de Santa Terezinha de Goiás situado em posição mais ocidental, estendendo a atividade desta acresção até 540 Ma.

Em todos os estágios magmáticos estão assinalados o progressivo aumento em $\mathrm{SiO}_{2}, \mathrm{~K}_{2} \mathrm{O}$, LILE (Rb, Cs), HFSE (Zr, Y, Nb, Th, U) e ETR. Spidergramas e curvas de ETR marcam rochas com padrões típicos de magmas calci-alcalinos geradas em zonas de subducção com certa contribuição crustal. Estão enriquecidas em LILE e ETRL e depletadas em HFSE e ETRP, com anomalias em $\mathrm{Nb}, \mathrm{P}$, Ti cada vez maiores.

$\mathrm{O}$ estágio arco continente apresenta os isótopos de $\varepsilon_{\mathrm{Nd}}$ e $\mathrm{T}_{\mathrm{DM}}$ compatíveis aos dados químicos. Exibem $\mathrm{T}_{\mathrm{DM}}$ com distribuição ampla e características de fontes mistas e heterogêneas, com rochas de derivação crustal e $\mathrm{T}_{\mathrm{DM}}$ sugestiva de alta residência crustal, de 2610 a $970 \mathrm{Ma}$ e $\varepsilon_{\mathrm{Nd}}$ entre -25.44 a -0.60 , sugerindo a presença de crostas arqueanas a neoproterozóicas recicladas. Rochas com fontes juvenis possuem $\mathrm{T}_{\mathrm{DM}}$ menor e variável de 1400 Ma a 760 Ma. Apresentam valores de $\varepsilon_{\mathrm{Nd}}$ entre +0.01 e +8.01 .

No estágio pós-colisional são encontrados tonalitos e granodioritos com idades entre 590$554 \mathrm{Ma}$ e alguns com tendência adakitica. As ocorrências estão dispersas em vários plútons e corpos isolados e estirados ao longo de centenas de quilômetros no LTB.

São identificados dois grupos pela forma e local de intrusão. O grupo identificado como de tendência adakítica que ocorrem dentro de áreas com o contexto geológico do embasamento e apresentam $\mathrm{T}_{\mathrm{DM}} 3.38$ e $1.75 \mathrm{Ga}$ de alta residência crustal e $\varepsilon_{\mathrm{Nd}}\left(\mathrm{T}_{0.58}\right)$ negativos entre -31.54 e -6.07. Um segundo grupo e mais numeroso possui valores de idades $\mathrm{T}_{\mathrm{DM}}$ entre 0.97 e $0.96 \mathrm{Ga}$ e $\varepsilon_{\mathrm{Nd}}\left(\mathrm{T}_{0.58}\right)$ entre -0.60 e -0.95 de derivação crustal. Datados U-Pb em zircão apontam idades de 590-554 Ma.

Todos os grupos estudados atendem os requisitos para classificação química de adakitos HSA (Alta $\mathrm{SiO}_{2}$ ), em geral todos possuem, alto $\mathrm{Na}_{2} \mathrm{O}>4 \%$, baixas razões $\mathrm{K}_{2} \mathrm{O} / \mathrm{Na}_{2} \mathrm{O}<0.5$, curvas de ETR muito fracionadas, sem anomalias de $\mathrm{Eu}$, alto $\mathrm{Sr}(>631 \mathrm{ppm})$, baixo $\mathrm{MgO} \%$ (<1.8, baixo), Y (<13 ppm), alta razão $\mathrm{Sr} / \mathrm{Y}>30$ e >50(média), Yb (< $1.13 \mathrm{ppm})$, alta razão $\mathrm{La} / \mathrm{Yb}(>45)$ e (La)n/(Yb)n (>30), baixo HFSE, como $\mathrm{Nb}<8$ ppm (média), Ta<0.5 ppm (média). Comparados às demais ocorrências de adakitos mundiais em ambientes pós-colisão os dados apresentados indicam uma correlação satisfatória ao fase fechamento dos orógenos.

Os dados químicos sugerem uma fusão primária parcial abaixo de 5\% na base da crosta máfica continental entre os campos de rutilo eclogito e anfibolito-hornblenda eclogito com anfibolitoCpx-granada no resíduo. Em todas as hipóteses a profundidade de geração é superior a $40 \mathrm{~km}$. 
A proposta de derivação das rochas como produtos relacionados à delaminação e fusão da crosta inferior, no final do Neoproterozóica parece ser a mais razoável, pois classifica, conforme indicado pela ambientação geotectônica os adakitos HSA como de contexto pós-colisional e concordantes com dados geofísicos que apontam anomalias positiva Bouguer e espessuras mais finas da crosta sob o arco e é coerente com o estágio tardio, pós colisional do Arco de Santa Terezinha de Goiás

Os orógenos Brasília e Araguaia correspondem strictu senso a um complexo orogênico de longa duração, desde o neoproterozóico ao cambriano, na Província Tocantins e compreende uma colagem de domínios oceânicos, núcleos e fragmentos continentais e arcos acrescionários de 900 a $800 \mathrm{Ma}$, interrupções do registro e retomadas acrescionários de $660 \mathrm{Ma}$ a $540 \mathrm{Ma}$. O termo complexo orogênico envolve suas distintas acresções, acoplagem de fragmentos crustais e o docking a blocos continentais pré-existentes.

O Lineamento Transbrasiliano (LTB) é essencial na colagem e formação destes arcos é responsável pela acresção do arco insular e docking por meio de uma subducção obliqua a uma porção continental. A deformação nesta etapa, é marcada pelo forte encurtamento crustal submetido às rochas do arco intra-oceânico contra a sua plataforma/bloco crustal onde se ancorou, e está materializada na falha do Rio dos Bois e sua continuidade para norte, que acomodou parte da deformação ao longo da primeira linha de sutura.

Em estagio posterior ao longo da zona de subducção do arco continental e até a fase colisional passou de um sistema obliquo a cada vez mais longitudinal, com a formação de falhas reversas de baixo ângulo as bordas, com escape lateral e ajustando grande parte da deformação ao longo de sua posição meridiana de alto ângulo e transcorrente.

Nesta fase instalam-se as grandes movimentações de massa, estiramento e embaralhamento tectônico dos compartimentos envolvidos após sua completa acresção. O limite do arco continental mais jovem a oeste coincide com uma lasca de embasamento de idade $2.1 \mathrm{Ga}$, e marca a junção que estabelece os limites das orógenos Araguaia e Brasília, e mara uma segundo zona de sutura.

A porção central dos compartimentos magmáticos fica balizada em campo pelas zonas granulíticas de Porangatu e Porto Nacional, que representam a infracrosta alçada e exumada entre 590 Ma e 540 Ma. Os granulitos marcam uma zona de sutura na parte central do Lineamento Transbrasiliano, realçada por expressivas zonas de cisalhamento e identificada por importantes descontinuidades magnéticas. Os deslocamentos direcionais tardios e de alto ângulo serão os responsáveis por esconder ou mascarar alguns sistemas de falhas iniciais e as zonas de suturas. 
O LTB e o AMG em sua porção setentrional se combinam em um segmento estreito e unico. No espaço limitado e inferior a $80 \mathrm{~km}$ de largura dois arcos magmáticos e seu embasamento são encaixados ao longo de uma zona de cisalhamento do tipo strike slip em um modelo de acresção transcorrente.

O tempo de vida, as características isotópicas e a mistura dos segmentos envolvidos definem este conjunto e o LTB como um complexo orogênico na orção setentrional do Orógeno Brasília. Neste sentido, o LTB além de assinalar uma das maiores feições estruturais da plataforma sulamericana, uma Zona de Cisalhamento Transcontinental, corresponde também há varias zonas de suturas internas do W-Gondwana em um estrutura do tipo "рор up". Esta peculiaridade deve se prolongar por sob a Bacia do Parnaíba para a Província Borborema, até sua conexão ao continente africano com o lineamento Hoggar-Kandi. 


\section{Capítulo 8 - Referências}

Alkmim, F.F.; Brito Neves, B.B. \& Castro Alves, J.A. -1993 - Arcabouço tectônico do Cráton do São Francisco: uma revisão. In: O Cráton do São Francisco. Dominguez, J.M.L. \&Misi, A.(ed), SBG - Núcleo BA/SE: 45-62

Almeida, F. F. M. de. 1965, Geologia da Serra da Bodoquena (Mato Grosso), Brasil. Boletim da Divisão de Geologia e Mineralogia, v. 219, p. 1- 96.

Almeida, F.F.M., 1967. Observações sobre o Pré-cambriano da Região Central de Goiás. Curitiba. Bol. Paranaense de Geociências, 26. p. 19-22.

Almeida, F. F. M., 1968. Evolução tectônica do centro-oeste brasileiro no proterozóico superior. Anais Acad. Bras. Ciências, n. 40, p. 285-295.

Almeida, F.F.M., 1974. Sistema tectônico marginal do Cráton do Guaporé;. In. Congresso Brasileiro de Geologia, 28. Porto Alegre. Anais do.SBG. V4, p5-9.

Almeida, F. M. M.; Hasui, Y., Brito-Neves, B. B., 1976. The Upper Precambrian of South América. Boletim do Instituto de Geociências, Universidade de São Paulo, v. 7, p. 45-80.

Almeida, F. F. M., 1977. O Cráton do São Francisco. Revista Brasileira de Geociências, São Paulo, n. 7, p. 349364.

Almeida, F. M. M., 1981. Brazilian structural provinces: an introduction; Earth Science Review, n. 17, p. 1-29.

Almeida, F.F.M. 1984. Província Tocantins - setor sudoeste. In: Almeida, F.F.M. \& Hasui, Y. eds. O PréCambriano do Brasil São Paulo, Ed. Blücher. p. 265-281.

Alvarenga, C. J. S. de; Trompette, R. 1993. Evolução tectônica brasiliana da Faixa Paraguai: a estruturação da região de Cuiabá. Revista Brasileira de Geociências, v. 23, p. 18-30.

Anderson, H.E., Davis, D.W., 1995. U-Pb geochronology of the Moyie sills, Purcell Supergroup, southeastern British Columbia: implications for the Mesoproterozoic geological history of the Purcell (Belt) basin. Can. J. Earth Sci. $32,1180-1193$.

Araújo Filho, J. O. de ; Marshak, S. . The Pirineus Syntaxis: an example of two separate non-coaxial Brasiliano fold-thrust belts in central Brazil . Revista Brasileira de Geociências, Rio de Janeiro, 2000.

Armstrong,R.L.,1981. Radiogenic isotopes; the case for crustal recycling on a near-steady-state no-continentalgrowth Earth. Royal Society of London Philosophical Transactions, 301 (1981), pp. 443-472

Arth, J.G., Hanson, G.N., 1972. Quartz-diorites derived by partial melting of eclogite or amphibolite at mantle depth. Contributions to Mineralogy and Petrology 37, 164-174.

Assumpção, M.S.; Lima T.M. \& Tomás L.A.R. (1986) O Sismo de Araguapazde 14.01 .1986 e o Lineamento Transbrasiliano, $34^{\circ}$ Cong. Bras. Geol., pp. 237-240 
Assumpção, M. M., Schimmel, C., Escalante, J.R., Barbosa, M. Rocha; 2004. Intraplate seismicity in SE Brazil: stress concentration in lithospheric thin spots. Geophysical Journal International 159 (1), 390-399

Atherton, M.P., Petford, N., 1993. Generation of sodium-rich magmas from newly underplated basaltic crust. Nature $362,144-146$

Baer, A.J., 1981a. Geotherms, evolution of the lithosphere and plate tectonics. Tectonophysics 72, $203-227$.

Baldwin \& Brown, 2008. Age and duration of ultrahigh-temperature metamorphism in the Anápolis-Itauçu Complex, Southern Brasília Belt, central Brazil - constraints from U-Pb geochronology, mineral rare earth element chemistry and trace-element thermometry. Journal of Metamorphic Geology. Volume 26, Issue 2, pages 213-233,

Barbosa et al., 1969. Projeto Brasília-Goiás: Geologia e Inventário dos Recursos Minerais. Goiânia: DNPM, 225p

Barker, F. \& Arth, J.G., 1976. Generation of trondhjemite-tonalitic liquids and Archaean bimodal trondhjemitebasalt suites. Geology, 4: 596-600.

Barnes, C.G., Petersen, S.W., Kistler, R.W., Murray, R., Kays, M.A., 1996. Source and tectonic implications of tonalite-trondhjemite magmatism in the Klamath Mountains.

Barth, M.G., Jenner, G.A., 2000. Rutile/melt partition coefficients for trace elements and an assessment of the influence of rutile on the trace element characteristics of subduction zone magmas. Geochimica et Cosmochimica Acta 64, 933-938.

Barton, C. (2002). "Marie Tharp, oceanographic cartographer, and her contributions to the revolution in the Earth sciences". Geological Society, London, Special Publications 192 (1): 215-228.

Basei, M. A. S., Brito Neves, B. B., Oswaldo, S. J., Babinski, M., Pimentel, M. M., Tassinari, C. C. G., Hollanda, M. H. B., Nutman, A., Cordani, U. G., 2010. Contribution of SHRIMP U-Pb zircon geochronology to unravelling the evolution of Brazilian Neoproterozoic fold belts. Precambrian Research 183 112-144.

Batchelor, R. A.; Bowden, P. 1985. Petrogenetic interpretation of granitoid rocks series using multicationic parameters. Chemical Geology, n. 48, p.43-55.

Botelho, N.F., Fuck, R.A., Dantas, E.L., Laux, J.L., Junges, S.L., 2006. The Paleoproterozoic peraluminous Aurumina granite suíte, Goiás and Tocantins: whole rock geochemistry and Sm-Nd isotopic constraints. In: The Paleoproterozoic Record of the São Francisco Craton, Brazil, IGCP 509, Brazil, September 9-21.

Boynton, W.V. 1984. Cosmochemistry of the rare-earth elements: meteorite studies. Henderson, P. Ed. Rare-Earth Elements Geochemistry. Elsevier. Amsterdam, p. 63-114.

Brito Neves, B. B., Campos Neto,Mário da Costa, Fuck, Reinhardt Adolfo, 1999. From Rodinia to Western Gondwana: An approach to the Brasiliano-Pan African Cycle and orogenic collage. Episodes, Vol. 22, no. 3.

Brito Neves, B.B., Fuck R.A. (2013). Neoproterozoic evolution of the basement of the South-American platform Journal of South American Earth Sciences 4772 e 89.

Brito Neves, B.B., Fuck, R. A., Pimentel, M. M.. 2014. The Brasiliano collage in South America: a review. Brazilian Journal of Geology, 44(3): 493-518.

Brown G.C., Thorpe R.S., Webb P.C., 1984. The geochemical chacteristics of granitoids in contrasting arcs and comments on magma sources. J Geol Soc Lond 141:413-426 
Brown, C.G., 1982. Calc-alkaline intrusive rocks: their diversity, evolution, and relation to volcanic rocks. In: Thorpe, R.S. (Ed.), Andesites. Wiley, Chichester, pp. 437-461.

Bruguier, O., Bosch, D., Pidgeon, R.T., Byrne, D.I., Harris, L.B., 1999. U-Pb chronology of the Northampton Complex, Western Australia: evidence for Grenvillian sedimentation, metamorphism and deformation and geodynamic implications. Contrib. Mineral. Petrol. 136, 258-272.

Bühn, B.; Pimentel, M. M.; Matteini, M.; Dantas, E. L. High spatial resolution analysis of Pb and U isotopes for geochronology by laser ablation multi-collector inductively coupled plasma mass spectrometry (LA-MC-IC-MS). Anais da Academia Brasileira de Ciências, v. 81, p. 99-114, 2009.

Caby, R., 1994. Precambrian coesite from northern Mali: first recordand implications for plate tectonics in the trans-Saharan segment of the Pan-African belt. European Journal of Mineralogy 6, 235244.

Casquet,C., Rapela,C.W., Pankhurst,R.J.,. Baldo, E.G, Galindo C., Fanning C.M., Dahlquist, J.A. Saavedra, J. A history of Proterozoic terranes in southern South America: From Rodinia to Gondwana.Geoscience Frontiers 3(2) (2012) $137 \mathrm{e} 145$

Castillo, P.R., 2006. An overview of adakite petrogenesis. Chinese Science Bulletin 51,258-268.

Castillo, P.R., 2012. Adakite petrogenesis. Lithos 134-135, 304-316.

Castillo, P.R., Janney, P.E., Solidum, R.U., 1999. Petrology and geochemistry of Camiguin Island, southern Philippines: insights to the source of adakites and other lavas in a complex arc setting. Contributions to Mineralogy and Petrology 134, 33-51.

Cawood, P. A., 2005.Terra Australis Orogen: Rodinia breakup and development of the Pacific and Iapetus margins of Gondwana during the Neoproterozoic and Paleozoic. Earth-Science Reviews, Volume 69, Issues 3-4, Pages 249-279.

Cawood, P.A., Buchan, C., 2007. Linking accretionary orogenesis with supercontinent assembly. Earth-Science Reviews 82, 217-256.

Cawood, P.A., Hawkesworth, C.J., Dhuime, B., 2013. The continental record and the generation of continental crust. Geological Society of America Bulletin 125, 14-32.

Chiarini M.F.N., 2007. Contribuição da aerogeofísica na caracterização de suturas colisionais e de sistemas transcorrentes. O exemplo de Porangatu Brasil central. Dissertação de Mestrado n 231. Universidade de Brasília (UnB), Brasília, DF, Brasil.

Chung, S.L., Liu, D., Ji, J., Chu, M.F., Lee, H.Y., Wen, D.J., Lo, C.H., Lee, T.Y., Qian, Q., Zhang, Q., 2003. Adakites from continental collision zones: melting of thickened lower crust beneath southern Tibet. Geology 31, 10211024 .

Condie, K.C., 1998. Episodic continental growth and supercontinents: a mantle avalanche connection? Earth and Planetary Science Letters 163, 97-108.

Condie, K.C., 2000. Episodic continental growth models: afterthoughts and extensions. Tectonophysics 322, 153162. 
Condie, K.C., 2005. TTGs and adakites: are they both slab melts? Lithos 80 (1-4), 33-44.

Condie, K., 2007. Accretionary orogens in space and time. Geological Society of America Memoirs 2007;200;145158

Condie, K., 2011. Earth as an Evolving Planetary System Academic Second edition.

Condie, K., 2012. Plate Tectonics and Crustal Evolution,. Fourth edition. Butterworth-Heinemann Ed.

Cordani, U.G., Sato, K., Teixeira, W., Tassinari, C.C.G., Basei, M.A.S., 2000. Crustal evolution of the South American platform. In: Cordani, U.G., Milani, E.J., Thomaz Filho, A., Campos, D.A. (Eds.), Tectonic Evolution of South America, pp. 19-40.

Cordani, U. G., Pimentel, M. M., Araújo, C. E. G., Fuck, R. A.; 2013. The significance of the TransbrasilianoKandi tectonic corridor for the amalgamation of West Gondwana. Braz. J. Geol., São Paulo, 43(3): 583-597.

Cordani, U.G, W. Teixeira, M.S. D'Agrella-Filho , R.I. Trindade, 2009. The position of the Amazonian Craton in supercontinents. Gondwana Research 15 396-407.

Costa L. A. M.; e Angeiras A. G., 1970. Zonas Tectônicas do Geossinclinal Pré-Cambriano do Brasil Central. In: Congresso Brasileiro De Geologia, 24, 1970, Brasília. Res. Conf. Brasília: SBG-Núcleo Centro-Oeste, p.164-166.

Costa, J. B. S., 1985. Aspectos Litoestruturais e Evolução Crustal da Região Centro-Norte de Goiás. 1985. 209p. Tese (Doutorado) - Núcleo de Geociências Geofísicas e Geológicas, Universidade Federal do Pará, Belém.

Costa, J. B. S.; Hasui, Y.; Gorayeb, P. S. S. 1988. Relações estruturais entre o Cinturão Orogênico Araguaia e o Maciço Goiano. In: 35 Congresso Brasileiro de Geologia, Belém. Anais. Belém: SBG, 1988. v. 5. p. 2187-2196.

Costa, J. B. S. ; Hasui, Y. ; Haralyi, N. L. E.1988. A zona de articulação dos blocos Brasília e Araguacema no Centro-Norte de Goiás. In: 35 CONGRESSO BRASILEIRO DE GEOLOGIA, Belém. Anais. Belém: Sociedade Brasileira de Geologia, 1988. p. 2197-2207.

Costa, J. B. S. ; Hasui, Y. 1988. Aspectos do Lineamento Transbrasiliano na região de Porto Nacional-Natividade, GO. In: 35 Congresso Brasileiro de Geologia, Belém. Anais. Belém: SBG, 1988. v. 5. p. 2208-2216

Courtillot, V., Davaille, A., Besse, J., Stock, J., 2003. Three distinct types of hotspots in the Earth's mantle. Earth Planet. Sci. Lett. 205, 295-308.

Cunha, B.C.C. et al. Geologia da Folha SC.22 Tocantins. In : BRASIL, Dep. Nac. Prod. Min., Projeto RADAMBRASIL. Rio de Janeiro, 1981. v.22, p.21-196.

Dalziel, I. W. D., 1991. Pacific margins of Laurentia and East Antarctica-Australia as a conjugate rift pair: Evidence and implications for an Eocambrian supercontinent, Geology, 19, 598-601, Geology, 19, 598-601.

Dalziel, I.W.D L.A. Lawver, J.B. Murphy, 2000. Plumes, orogenesis, and supercontinental fragmentation. Earth and Planetary Science Letters . Volume 178, Issues 1-2, 15 May, Pages 1-11

Dalziel, I.W.D., Soper, N.J., 2001. Neoproterozoic extension on the Scottish Promontory of Laurentia; paleogeographic and tectonic implications. Journal of Geology 109, 299-317. 
Dantas, E.L.; Jost H.; Fuck, R. A.; Brod, J.A.; Pimentel M.M.; Meneses, P. 2001. Proveniência e idade deposicional de seqüências metavulcano-sedimentares da região de Santa Terezinha de Goiás, baseada em dados isotópicos Sm$\mathrm{Nd}$ e U-Pb em monocristal de zircão. Revista Brasileira de Geociências, v. 31, p. 329-334.

Dantas, E. L.; Martinelli, C. C. Nd isotopes from the Araés Metavocano-sedimentary sequence in the Paraguay Belt, Nova Xavantina, Mato Grosso, Central Brazil. In: South American Symposium On Isotope Geology, 4., 2003, Salvador. Short Papers...Salvador: CBPM/IRD, 2003. v. 1. p. 168-169.

Dantas, E. L., Araújo Filho, J. O.; Oliveira, C. G. de, Chiarini, M. F. N., Fuck, R. A., De Sordi, D. A.; 2007. Nota Explicativa Da Folha Porangatu (SD.22-X-D-I) 1:100.000 - CPRM.

Dantas, E.L; Fuck, R.A.; Oliveira C. G.; Araújo, J. O; Roig H. L.; Almeida, T.; Vidotti, R. M.;Frasca, A.A.S; 2013. Compartimentação tectônica e cinemática da porção NE da Província Tocantins. XIV Simpósio Nacional de Estudos Tectônicos, VIII Internacional Symposium on Tectonics. Chapada dos Veadeiros, MT.

Dardenne, M. A. Zonação Tectônica na borda ocidental do Cráton do São Francisco. In: Congresso Brasileiro de Geologia, 30, 1978, Recife. Anais. Recife: SBG, 1978. v.1, p. 299-308.

Dardenne M. A. The Brasilia fold belt. In: Cordani, U. G.; Milani, E. J.; Thomaz Filho, A. (Eds) Tectonic Evolution of South America. In: International Geological Congress, 31, 2000, Rio de Janeiro. Rio de Janeiro, 2000. p.231.

Defant, M.J., Drummond, M.S., 1990. Derivation of some modern arc magmas by melting of young subducted. lithosphere. Nature 367, 662-665.

Defant, M.J., Drummond, M.S., 1993. Mount St. Helens: potential example of the partial melting of the subducted lithosphere in a volcanic arc. Geology 21, 547-550

Delgado I.M., 2003: in Bizzi; Schobbenhaus, C., Vidotti, R. M., Gonçalves J. H. Geologia, Tectônica e Recursos Minerais do Brasil, (eds.) CPRM, Brasília.

Della Giustina M.E.S., Oliveira C.G., Pimentel M.M., Bühn B. 2009. Neoproterozoic magmatism and high-grade metamorphism in the Goiás Massif: New LA-MC-ICMPS U-Pb and Sm-Nd data and implications for collisional history of the Brasília Belt. Precambrian Research, 172(1-2):67-79.

Depaolo, D. I., 1988. Neodymiun isotope geochemistry: An introduction. Springer, Minerals and rocks, n. 20. $187 \mathrm{p}$.

DePaolo, D.J., 1981. A neodymium and strontium isotopic study of the mesozoic calc-alkaline granitic batholiths of the sierra Nevada and Peninsular Ranges, California. Journal of Geophysical Research 86.

Dewey, J.F. \& Bird, J.M. 1970. Mountain belts and the new global tectonics. J. geophys. Res. 75, $2625-47$.

Dewey, J.F., 2007. The secular evolution of plate tectonics and the continental crust: an outline. Geological Society of America Memoir 200, 1-7.

Dokuz, A., Tanyolu, E., Genç, S., 2006. A mantle- and a lower crust-derived bimodal suite in the Yusufeli (Artvin) area, NE Turkey: trace element and REE evidence for subduction-related rift origin of Early Jurassic Demirkent intrusive complex. International Journal of Earth Sciences 95, 370-394. 
Drago VA. 1981. Projeto RADAMBRASIL - Folha SD.22-Goiás, geologia, geomorfblogia, solos, vegetação e uso potencial da terra. Rio de Janeiro, DNPM. (Levantamento de Recursos Naturais).

Drummond, M. S., Defant, M. J. and Kepezhinskas, P.K., 1996. Petrogenesis of slab-derived trondhjemite tonalite-dacite/adakite magmas. Transactions of the Royal Society of Edinburgh, Earth Sciences 87, $205-215$.

Drummond, M.S., Defant, M.J., 1990. A model from trondhjemite-tonalite-dacite genesis and crustal growth via slab melting: Archaean to modern comparisons. Journal of Geophysical Research 95, 21503-21521.

Ernst, R.E., Buchan, K.L., 2002. Maximum size and distribution in time and space of mantle plumes; evidence from large igneous provinces. In: Condie Kent, C., Abbott Dallas, H., Des Marais David, J. (Eds.), Superplume Events in Earth History; Causes and Effects. Pergamon Press, Oxford, United Kingdom.

Ernst, W.G.,2007. Speculations on evolution of the terrestrial lithosphere-asthenosphere system-Plumes and plates. Gondwana Research 11 (2007) 38-49.

Evans, D.A.D., 2003. A fundamental Precambrian-Phanerozoic shift in earth's glacial style? Tectonophysics 375 , 353-385.

Evans, D.A.D., 1998. Supercontinental cycles and true polar wander. In: Bird, Robert, T., Powell, Christopher, McA., Wingate (Eds.), The Assembly and Breakup of Rodinia; Proceedings of a Workshop. Abstracts. Geological Society of Australia, Sydney, NSW, Australia, pp. 34-35.Evans, 1998.

Feng, M., Van Der Lee, S. \& Assumpcao, M., 2007. Upper mantle structure of South America from joint inversion of waveforms and fundamental mode group velocities of Rayleigh waves, J. geophys. Res. ,112 (B04312), 16 pp.

Ferreira Filho C.F. 1994. The Niquelândia mafic-ultramafic intrusion, North goiás, Brazil: petrology and potential for PGE ore deposits. $\mathrm{PhD}$ thesis. University of Toronto, Toronto, $270 \mathrm{p}$.

Fetter A.H., Santos T.J.S., Van Schmus W.R., Hackspacher P.C., Brito Neves B.B., Arthaud M.H., Nogueira Neto J.A., Wernicka E. 2003. Evidence for Neoproterozoic continental arc magmatism in the Santa Quitéria Batholith of Ceará State, NW Borborema Province, NE Brazil: Implications for the assembly of West Gondwana. Gondwana Research, 6(2):265-273.

Fitzsimons, I.C.W., 2003. Proterozoic basement provinces of southern and southwestern Australia, and their correlation with Antarctica. In: Yoshida, M.,Windley, B.F., Dasgupta, S. (Eds.), Proterozoic East Gondwana: Supercontinent Assembly and Breakup. Special Publications, Geological Society, London, pp. 93-130.

Foley, S.F., Tiepolo, M., Vannucci, R., 2002. Growth of early continental crust controlled by melting of amphibolite in subduction zones. Nature 417, 637-640.

Fonseca, M. A. Estilos estruturais e o arcabouço Tectônico do Segmento Setentrional da Faixa Brasília. 172p. 1996. Tese. (Doutorado) - Instituto de Geociências, Universidade de Brasília, Brasília,1996.

Fonseca, M. A.; Dardenne, M. A.; Uhlein, A.A., 1995. Faixa Brasília, Setor Setentrional: Estilos Estruturais e Arcabouço Tectônico. Revista Brasileira de Geociências, São Paulo, v.25, n.4, p.267-278.

Foster, D.A.; Gray, D.R. 2008. Paleozoic crustal growth, structure, strain rate, and metallogeny in the Lachlan orogen, eastern Australia. Arizona Geological Society Digest 22. 
Frasca, A. A. S. Lima, H.A.F., 2010. Projeto Sudeste do Tocantins. Geologia e Recursos Minerais da Folha Gurupi (SD.22-Z-DC). Estado de Tocantins. Escala 1:250.000. Goiânia: Serviço Geológico Do Brasil, s.d. 1 CD-ROM.

Frasca, A. A. S.; Lacerda Filho, J.V; Ribeiro, P.S.E; Villas Boas, P.F.M; Moraes, L.L; Lima, H.A.F.. Projeto Sudeste do Tocantins. Geologia e Recursos Minerais da Folha Alvorada (SD.22-X-B). Estado de Tocantins, 2012. Mapa Escala 1:250.000. Goiânia: Serviço Geológico do Brasil, s.d. 1 CD-ROM.

Frasca, A.A.S., Dantas, E.L., Fuck, R.A., Scandolara, J.E., in press. Arc migration and strike slip systems : the case of Neoproterozoic Goiás Magmatic arc, Central Brazil.

Fritz H., M. Abdelsalam, K.A. Ali, B. Bingen, A.S. Collins, A.R. Fowler, W. Ghebreab,C.A. Hauzenberger, P.R. Johnson, T.M. Kusky, P. Macey, S. Muhongo, R.J. Stern 1, G. Viola; 2013. Orogen styles in the East African Orogen: A review of the Neoproterozoic. to Cambrian tectonic evolution. Journal of African Earth Sciences 86 (2013) 65-106.

Frost, B. R., Barnes, C. G., Collins, W. J., Arculus, R. J., Ellis, D. J. \& Frost, C. D. (2001). A geochemical classification for granitic rocks. Journal of Petrology $42,2033-2048$.

Fuck, R. A.; Jardim de Sá, E. F.; Pimentel, M. M.; Dardenne, M. A.; Pedrosa Soares, A. C. 1993. As Faixas de Dobramentos Marginais do Cráton do São Francisco. In: Dominguez, J.M.L.; Misi, A.; SBG - Núcleo BA/SE; SEM; CNPq. (Org.). O Cráton do São Francisco. v. p. 161-186

Fuck, R. A. A faixa Brasília e a compartimentação Tectônica na Província Tocantins. In: Simpósio De Geologia Do Centro-Oeste, 4, 1994, Brasília. Anais Brasília: SBG, p. 184-187.

Fuck R. A. Dantas, E.L.; Pimentel,M.M.; Junges, S.L.; Moraes,R., 2002. Nd Isotopes, U-Pb Single Grain and SHRIMP Zircon Ages From Basement Rocks of the Tocantins Province. In: SSAGI, 4, Pucón, Chile, CD.81.

Fuck R. A., Dantas, E. L., De Sordi, D. A., Chiarini, M. F. N., Oliveira, C.G., 2006. Carta Geológica. Relatório Final da Folha SD.22-Z-A-III Santa Terezinha, Estado de Goiás. Escala 1:100.000. Brasília: UnB/Serviço Geológico Do Brasil.

Fuck, R. A.; Dantas, E. L.; Pimentel, M.M.; Junges, S. L.; Moraes, R., 2001. Nd isotopes, U-Pb single grain and SHRIMP zircon ages from basement rocks of the Tocantins Province. In: III South American Symposium on Isotope Geology, 2001, Pucon. Proceedings, Extended Abstract Volume (CD ROM). Santiago: Servicio Nacional de Geologia y Mineria, v. 1. p. 141-144

Fuck, R, A.; Dantas, E. L. ; Pimentel, M. M. ; Junges, Sergio ; Moraes, R.., 2001 Nd Isotopes, U-Pb single grain and SHRIMP zircon ages from basement rocks of the Tocantins Province. In: III South America Symposium on Isotope Geology, 2001, Pucon. Anais do III SSAGI.

Fuck, R. A. et al. 2005. Compartimentação da Faixa Brasília. In: Simpósio De Geologia Do Centro-Oeste, 9, Goiânia. Anais... Goiânia: SBG, 2005. p.26-27.

Fuck, R. A., Brito Neves, B. B., Schobbenhaus, C., 2008. Rodinia Descendants in South America. Precambrian Research 160, p108-126

Fuck, R. A. ; Dantas, E.L.; Vidotti, R.M. ; Roig, H. L. ; Almeida, T. 2013. Deformação intracontinental em sistemas transcorreentes: o caso do Lineamento Transbrasiliano, geometria, idade e significado, In: $14^{0}$ Simpósio Nacional de Estudos Tectônicos. Chapada dos Guimarães. Sociedade Brasileira de Geologia. p. 1-3. 
Fuck, R. A., Dantas, E. L., Pimentel, M. M., Botelho, N. F., Armstrong, R., Laux, J. H., Junges, S. L., Soares, J. E., Praxedes, I. F., 2014. Paleoproterozoic crust-formation and reworking events in the Tocantins Province, central Brazil: A contribution for Atlantica supercontinent reconstruction. ARTICLE IN PRESS Precambrian Research.

Fujimaki, H., Tatsumoto, M., Aoki, K., 1984. Partition coefficients of Hf, Zr and REE between phenocrysts and groundmass. Journal of Geophysical Research 89, 662-672.

Gao, S., Rudnick, R.L., Yuan, H., Liu, X., Liu, Y., Xu, W., Ling, W., Ayers, J., Wang, X., Wang, Q., 2004. Recycling lower continental crust in the North China Craton. Nature 432, 892-897.

Garnero, E.J., 2004. A new paradigm for Earth's core-mantle boundary. Science 304. doi:10.1126/science.1097849.

Geraldes, M. C.; Tassinari, C.C. G.; Onoe, A.T. 2003. 40Ar/39Ar mineralizing age of the Araés gold deposit, Mato Grosso State, Brazil.. In: Simposio Nacional de Estudos Tectônicos, Armação de Buzios. Boletim de Resumos, 2003.

Gioia, S.M.C.L., Pimentel, M.M., 2000. The Sm-Nd isotopic method in the geochronology laboratory of the University of Brasília. Anais da Academia Brasileira de Ciências 72 (2), 219-245.

Goldfarb, R.J., Bradley, D.C., Leach, D.L., 2010. Secular variation in economic geology. Economic Geology 105, $459-465$.

Gorayeb, P. S. S. 1996. Petrologia e evolução crustal das rochas de alto grau de Porto Nacional (TO). 1996. 262p. Tese. (Doutorado). Instituto de Geociências - Universidade Federal do Pará, Belém, 1996.

Gorayeb, P. S. S., Chaves; C. L.; Moura, C. A. V.; Lobo, L. R. S., 2013. Neoproterozoic granites of the Lajeado intrusive suite, north-center Brazil: A late Ediacaran remelting of a Paleoproterozoic crust. Journal of South American Earth Sciences, Volume 45, Pages 278-292.

Grandjean, C. F., 2008. Petrogênese do granodiorito fazenda gavião: registro de uma colisão arco-continente no greenstone Belt do Rio Itapicuru, Cráton do são Francisco, Bahia. Dissertação de Mestrado -UNICAMP - Campinas, São Paulo.

Gray, D.R., Foster, D.A., Meert, J.G., Goscombe, B.D., Armstrong, R., Truow, R.A.J., Passchier, C.W., (2007). A Damaran perspective on the assembly of southwestern Gondwana. Geological Society of London Special Publication.

Guo, F., Fan, W., Li, C., 2006. Geochemistry of late mesozoic adakites from the Sulu belt, eastern China: magma genesis and implications for crustal recycling beneath continental collisional orogens. Geological Magazine 143, 1-13.

Guttenberg, M. e Oliveira, E. P.,2010. Petrogenese dos ortognaisses Cipó e implicações para evolução crustal durante o paleoproterozoico no domínio Ceará Central da Província Borborema. Revista de geologia, Vol 23, n 1, 61-77.

Hasui,Y \& Almeida, F. F. M., 1970. Geocronologia do Centro Oeste brasileiro. Boletim Soc. Bras. Geol., v. 19, n. 1, p. 6-26, 1970

Hasui, Y, Abreu, F. A. M. \& Rangel, J. M. R. 1977. Estratigrafia da Faixa de Dobramentos Paraguai Araguaia no centro norte do Brasil.Bol. Inst. Geoc. -USP, v.8, p. 107-118.

Hasui, Y. ; Ponçano, W. L. 1978. Geossuturas e sismicidade no Brasil. In: 2 Congresso Brasileiro de Geologia de Engenharia, 1978, São Paulo. Anais. São Paulo: ABGE,. p. 331-338. 
Hasui, Y. et al. 1980. Datações Rb-Sr e K-Ar do Centro-Norte do Brasil e seu significado geológico-tectônico. In : congresso brasileiro de geologia, 31, Balneário de Camboriú-SC, Soc. Bras. Geol.,. Anais...v.5, p.2.542-2.550.

Hasui, Y. et al. 1984. Província Tocantins; Setor Setentrional, p. 187-203. In : Almeida, F.F.M. de; Hasui, Y. (Coord.). O Precambriano do Brasil. São Paulo, Edgard Blücher.

Hasui, Y.; Matta, M. A. S. 1992. As estruturas geológicas do maciço rochoso de fundação da UHE Tucuruí, Rio Tocantins (PA). In: Y Hasui; J A Mioto. (Org.). Geologia Estrutural Aplicada. São Paulo: Associação Brasileira de Geologia de Engenharia, v. , p. 245-260.

Hasui, Y; Costa, J. B. S.; Haralyi, N.L. Erwin; 1994. Estrutura em Quilha Brasil Central, Uma feição Fundamental na Geologia de Goiás e Tocantins. São Paulo, 13(2): 463-497.

Hasui, Y. 2010. A grande colisão pré-cambriana do Sudeste brasileiro e a estruturação regional. Geociências (São Paulo. Impresso), v. 20, p. 141-169.

Hasui, Y.; Carneiro, C. D. R.; Almeida, F. F. M.; Bartorelli, A., 2012. Geologia do Brasil, Ed. Beca. pag 118.

Hawkesworth, C.J., Dhuime, B., Pietranik, A.B., Cawood, P.A., Kemp, A.I.S., Storey, C.D., 2010. The generation and evolution of the continental crust. Journal of the Geological Society of London 167, 229-248.

Helmberger, D., Ni, S., Wen, I.L., Ritsema, J., 2000. Seismic evidence for ultralow-velocity zones beneath Africa and eastern Atlantic. Journal of Geophysical Research 105 (B10), 23865-23878.Herz, N., Hasui, Y., Costa, J. B. S. e Matta, M. A. S. 1989. The Araguaia fold belt, Brazil: a reactivated Brasiliano-Pan-African cycle (550 Ma) geosuture. Precambrian Research. vol. 42, p. $371-386$.

Hess, H.H. (1962) History of ocean basins. In Petrologic Studies: a volume in honor of A.F. Buddington, pp. 599620. Geological Society of America, New York.

Hoffman, P. F., Science, 1991, 252, 1409-1412.

Hoffman, P.F., 1999. The break-up of Rodinia, birth of Gondwana, true polar wander and the snowball Earth. Journal of African Earth Sciences 28, 17-33

Hoffman, P.F., Schrag, D.P., 2002. The snowball Earth hypothesis: testing the limits of global change. Terra Nova $14,129-155$.

Hou, M.L., Jiang, Y.H., Jiang, S.Y., Ling, H.F., Zhao, K.D., 2007. Contrasting origin of Late Mesozoic adakitic granitoids fron the northwestern Jiaodong Peninsula, east China: implications for crustal thickening to delemination. Geological Magazine 144, 619-631.

Huang, F., Li, S., Dong, F., He, Y., Chen, F., 2008. High-Mg adakitic rocks in the Dabie orogen, central China: implications for foundering mechanism of lower continental crust. Chemical Geology 255, 1-13.

Irvine, T. N.; Baragar, W. R. A. A guide to the chemical classification of the common volcanic rocks. 1971. Can.J. Earth Sci., v.8, p. 523-548.

Irving, A.J., Frey, F.A., 1978. Distribution of trace elements between garnet megacrysts and host volcanic liquids of kimberlitic to rhyolitic composition. Geochimica et Cosmochimica Acta 42, 771-787.

Ishihara, S., 1977. The magnetite-series and ilmenite-series granitic rocks. Min.Geol. 27, 293-305 
Ishihara, S., 2007. Origin of the Cenozoic-Mesozoic magnetite-series and ilmenite-series granitoids in East Asia. Gondwana Research 11 (2007) 247-260

Jackson, S.E., Pearson, N.J., Griffin, W.L., Belousova, E.A., 2004. The application of laserablation inductively coupled plasma-mass spectrometry to in situ U-Pb zircon geochronology. Chemical Geology 211, 47-69.

Janousek, V., Farrow, G., Erban, V., 2006. Interpretation of whole-rock geochemical data in igneous geochemistry: introducing Geochemical Data Toolkit (GCDkit). Journal of Petrology 47 (6), 1255-1259.

Johansson Åke, 2014. From Rodinia to Gondwana with the 'SAMBA' model-A distant viewfrom Baltica towards Amazonia and beyond. Precambrian Research 244 (2014) 226-235.

Johnson, K., Barnes, C.G., Miller, C.A., 1997. Petrology, geochemistry, and genesis of high-Al tonalite and trondhjemites of the Cornucopia stock, Blue Mountains, Northeastern Oregon. Journal of Petrology 38, 1585 - 1611.

Jost, H.; Chemale Jr, F.; Dussin, I. A. ; Tassinari, C. C. G. 2010. Goiás greenstone belts: Archean or Paleoproterozoic. In: 45 Congresso Brasileiro de Geologia, Belém. Anais do 45 Congresso Brasileiro de Geologia. São Paulo: Sociedade Brasileira de Geologia, 2010. v. CD-ROM. p. PAP33

Jost, H.; Chemale Jr., F.; Fuck, R. A.; Dussin, I. A. 2013.. Uvá complex, the oldest orthogneisses of the ArcheanPaleoproterozoic terrane of central Brazil. Journal of South American Earth Sciences, v. 47, p. 201-212, 2013.

Junges, S. L.; Pimentel, M. M.; Moraes, R., 2002. Nd isotopic study of the Neoproterozoic Mara Rosa Arc, central Brazil: implications for the evolution of the Brasília Belt. Precambrian Research, v.117, n.1-2, p.101-108.

Karsli, O., Ketenci, M., Uysal, İ., Dokuz, A., Aydin, F., Chen, B., Kandemir, R., Wijbrans, J., 2011. Adakite-like granitoid porphyries in the Eastern Pontides, NE Turkey: Potential parental melts and geodynamic implications. Lithos $127,354-372$.

Kotschoubey, B., Hieronimus, B., Albuquerque, C. A. R. 2005. Disrupted peridotites and basalts from the Neoproterozoic Araguaia Belt (Northern Brazil): remnants of a poorly evolved oceanic crust. Journal of South American Earth Sciences 20, 211-230,.

Kröner, A., 1981. Precambrian plate tectonics. In: Kröner, A. (Ed.), PrecambrianPlate Tectonics. Elsevier, Amsterdam, pp. 57-90.

Kröner, U., Cordani U.G., 2003. African, southern Indian and South American cratons were not part of the Rodinia supercontinent: evidence from field relationships and geochronology. Tectonophysics, 375(1-4):325-352.

Kroner, U., Romer, R.L., 2013. Two plates — Many subduction zones: The Variscan orogeny reconsidered. Gondwana Research 24 298-329

Kuyumjian, R.M. 1994. A seqüência Mara Rosa na região de Chapada, Goiás. In, SBG, Núcleo Brasília, Bol. Informativo, $17(1-2): 34-38$.

Lacerda Filho, J. V.; Rezende, A.; Silva, A., 1999. Programa de Levantamentos Geológicos Básicos. Geologia e Recursos Minerais do Estado de Goiás e Distrito Federal. Esc. 1:500.000. Goiânia: Serviço Geológico Do Brasil/METAGO-SA/UnB, 176p. 
Laux J.H. Evolução do Arco magmático de Goiás com base em dados Geocronológicos U-Pb e Sm-Nd. 2004. Tese (Doutorado) - Instituto de Geociências, Universidade de Brasília, Brasília, 2004.

Laux, J. H. et al. 2005. Two neoproterozoic crustal accretion events in the Brasília Bels, Central Brazil. Journal of South American Earth Sciences, v.18, n.2, p.183-198.

Lena, L.O.F., 2013. A evolução do arco magmático neoproterozoico São Gabriel, porção sul da Provincia Mantiqueira, baseado em idades U-Pb SHRIMP e LA-ICP-MS e valores $\delta^{18}$ em zircões detriticos. Dissertação de mestrado UFRGS. 85p.

Li, Z.X., Li, X.H., Kinny, P.D., Wang, J., 1999. The breakup of Rodinia: did it start with a mantle plume beneath South China? Earth Planet. Sci. Lett. 173, 171-181.

Li, Z.X., Cho, M., Li, X.H., 2003. Precambrian tectonics of East Asia and relevance to supercontinent evolution. Precambrian Res. 122, 1-6.

Li, Z.X., Evans, D.A.D., Zhang, S., 2004. A 90॰ spin on Rodinia: possible causal links between the Neoproterozoic supercontinent, superplume, true polar wander and low-latitude glaciation. Earth Planet. Sci. Lett. 220, $409-421$.

Li, Z.X., S.V. Bogdanova, A.S. Collins, A. Davidson, B. De Waelea, R.E. Ernst , I.C.W. Fitzsimons, R.A. Fuck, D.P. Gladkochub, J. Jacobs, K.E. Karlstrom, S. Lul, L.M. Natapov, V. Pease, S.A. Pisarevsky, K. Thrane, V. Vernikovsky, 2008. Assembly, config.tion, and break-up history of Rodinia: A synthesis. Precambrian Research 160 179-210.

Lima, H. A. F., Ferreira Filho, C. F., Pimentel, M. M., Dantas, E. L., Araújo, S. M., 2008. Geology, petrology and geochronology of the layered mafic-ultramafic intrusions of the Porto Nacional area, central Brazil. Journal of South American Earth Sciences 26, 300-317.

Lima, H.A.F., 2007. Geologia, Petrologia e Geocronologia das Intrusões Acamadadas Máficas-Ultramáficas de Porto Nacional, Tocantins, Brasil. Dissertação de Mestrado, Universidade de Brasília Instituto De Geociências.

Liu, S., Hu, R.-Z., Feng, C.-X., Zhou, H.-B., Li, C., Chi, X.-G., Peng, J.-T., Zhong, H., Qi, L., Qi, Y.-Q., Wang, T., 2008. Cenozoic high Sr/Y volcanic rocks in the Qiangtang terrane, northern Tibet: geochemical and isotopic evidence for the origin of delaminated lower continental melts. Geological Magazine 145, 463-474.

Ludwig K.R. 1993. PBDAT. A computer program for processing Pb-U-Th isotope data. USGS Open File Report $88-542,34 \mathrm{p}$.

Ludwig, K.R., 2001. User?s manual for Isoplot/Ex v. 2.47. A geochronological toolkitfor Microsoft Excel. BGC Special Publ. 1a, Berkeley, 55 pp.

Ludwig, K.R., 2003. Isoplot 3.00: A Geochronological Toolkit for MicrosoftExcel. Berkeley Geochronological Center, Special Publication 4,70p.

Machado, E. C. et al., 1981. Projeto Porangatu: relatório final, etapa II. DNPM/CPRM, 1.,. 246 p.

Maniar, Papu D.; Piccoli, Philip M. Tectonic discrimination of granitoids, Geological Society of América Bulletin, Pittsburgh, v.101, p.635-643, may 1989.

Mantesso-Neto V., Bartorelli A., Carneiro C.D.R., Brito Neves B.B. (eds.).2004. Geologia do Continente SulAmericano: Evolução da Obra de Fernando Flávio Marques de Almeida. São Paulo, Beca, 672 p 
.Marini, O. J. et al. 1981. A evolução geotectônica da Faixa Brasília e do seu Embasamento. In: Simpósio Sobre Cráton Do São Francisco E Suas Faixas Marginais, 1, Salvador. Anais. Salvador: SME-Serviço Geológico Do Brasil/SBG/NBASE, p.100-115.

Marini, O. J.; Fuck, R. A.; Dardenne, M. A.; Danni, J. C. M. 1984. Província Tocantins: setores Central e Sudeste. In: Almeida, F. F. M.;Hasui, Y. (Coord.), O Pré-cambriano do Brasil. São Paulo: Edgar Blücher,. p.205-264.

Martin, H., 1987. Petrogenesis of Archaean trondhjemites, tonalites and granodiorites from eastern Finland; major and trace element geochemistry. Journal of Petrology 28 (5), 921-953.

Martin, H., 1999. The adakitic magmas: modern analogues of Archaean granitoids. Lithos 46 (3), 411-429.

Martin, H., Moyen, J.-F., 2003. Secular Changes in TTG Composition: Comparison with Modern Adakites, EGSAGU-EGU Joint Meeting. VGP7-IFR20-001, Nice, April.

Martin, H., Smithies, R.H., Rapp, R.P., Moyen, J.-F., Champion, D.C., 2005. An overview of adakite, tonalitetrondhjemite-granodiorite (TTG) and sanukitoid: relationships and some implications for crustal evolution. Lithos 79 (1-2), 1-24.

Martins, G. e Oliveira, E.P., 2010. Petrogênese dos ortognaisses Cipó e implicações para evolução crustal durante o Paleoproterozóico no Domínio Ceara Central da Província Borborema. Revista de Geologioa, Vol.23, nº 1, 61-77.

Maruyama, S., Santosh M., Zhao D.,2007. Superplume, supercontinent, and post-perovskite: Mantle dynamics and anti-plate tectonics on the Core-Mantle Boundary. Gondwana Research 11 (2007) 7-37

Matteini, M. ; Junges, S.L. ; Dantas, E.L. ; Pimentel, M.M. ; Bühn, B. 2010. In situ zircon U Pb and Lu Hf isotope systematic on magmatic rocks: Insights on the crustal evolution of the Neoproterozoic Goiás Magmatic Arc, Brasília belt, Central Brazil. Gondwana Research, v. 17, p. 1-12.

Matteini, M, Mazzuoli R., Omarini, R., Cas, R., Maas, R. 2002. Geodynamical evolution of Central Andes at $24^{0}$ S as inferred by magma composition along the Calama-Olacapato-El Toro transversal volcanic belt. Journal of Volcanology and Geothermal Research 118 205-228.

McCulloch, M.T., Bennett, V.C., 1994. Progressive growth of the Earth's continental crust and depleted mantle. Geochimica et Cosmochimica Acta 58, 4717-4738.

McKenzie, D.P. \& Parker, R.L. (1967) The North Pacifi c: an example of tectonics on a sphere. Nature 216, 127680.

McMenamin, Mark A. S.; McMenamin, D. S., 1990. The Emergence of Animals: The Cambrian Breakthrough. Columbia University Press. ISBN 0-231-06646-5.

McNamara, Allen K. Conall Mac Niocaill, Ben A. van der Pluijm, Rob Van der Voo, 2001. West African proximity of the Avalon terrane in the latest Precambrian. Geological Society of America Bulletin, September. v. 113; no. 9; p. 1161-1170.

Moores, E. M., \& Twiss, R. J., 1995. Tectonics (415 pp). New York: W. H. Freeman

Moores, E.M., 1991. Southwest U.S.-East Antarctic (SWEAT) connection: a hypothesis. Geology 19, 425 -428. 
Moores, E.M., 2002. Pre-1 Ga (pre-Rodinian) ophiolites: their tectonic and environmental implications. Geol. Soc. Am. Bull. 114, 80-95.

Moraes, R., Fuck, R. A., Pimentel, M. M., Gioia S. M. C. L., Figueiredo, A. M. G., 2003. Geochemistry and SmNd isotopic characteristics of bimodal volcanic rocks of Juscelandia, Goiás, Brazil: Mesoproterozoic transition from continental rift to ocean basin. Precambrian Research 125 317-336

Moura, C. A. V., Gaudette, H. E., 1999. Zircon ages of the basement Orthogneisses from the Northern Segment of the Araguaia Belt, Brazil. In.: SINHA, A. K. Basement Tectonic. 13 ed. Holanda:Kluwer Academic Publischers,. p. $155-178$.

Moura, C.A. V; Souza, S. H. P, 1996. Síntese dos dados geocronológicos das rochas do embasamento do Cinturão Araguaia e suas implicações estratigráficas. In. Congresso Brasileiro de Geologia, 39. Anais . Salvador: SGB, v.6, p. 31-34.

Moyen, JF, 2009. High Sr/Y and La/Yb ratios: The meaning of the adakitic signature. Lithos $112556-574$.

Muir, R.J., Weaver, S.D., Bradshaw, J.D., Eby, G.N., Evans, J.A., 1995. Geochemistry of the Cretaceous Separation Point Batholith, New Zealand: granitoid magmas formed by melting of mafic lithosphere. Journal of the Geological Society of London 152, 689-701.

Murphy, J.B., Nance, R.D., 2003. Do supercontinents introvert or extrovert?: Sm-Nd isotopic evidence. Geology 31, 873-876.

Nance, R. D., Worsley, T. R., \& Moody, J. B. 1986. Post Archean biogeochemical cycles and long-term episodicity in tectonic processes. Geology, 14, 524-1518.

Nance, R. Damian, J. Brendan Murphy, M. Santosh, 2014. The supercontinent cycle: A retrospective essay. Gondwana Research 25, p 4-29.

Nance, R. Damian, Murphy J. Brendan, 2013. Origins of the supercontinent cycle. Geoscience Frontiers 4 p439448 .

Northfleet A.A., Medeiros R.A., Mülhmann H. 1969. Reavaliação dos dados geológicos da Bacia do Paraná. Boletim Técnico da Petrobrás, 12(3):291-346.

Omrani J., Agard, P., Whitechurch, H., Benoit M., Prouteau, G., Jolivet, L., 2008. Arc-magmatism and subduction history beneath the Zagros Mountains, Iran: A new report of adakites and geodynamic consequences. Lithos 106 (2008) 380-398.

Osborne, G. A., 2013. Geotectonics and Mineralization in the Ophiolite Assemblages of the Araguaia Marginal Basin, Pará and Tocantins States, Central Brazil. VII SGA V8 Santarem PA.

Paixão M. A. P., A. A. Nilson and E. L. Dantas. 2008. The Neoproterozoic Quatipuru ophiolite and the Araguaia fold belt, central-northern Brazil, compared with correlatives in NW Africa. Society Geological of London, Special Publications, v. 294; p. 297-318; doi:10.1144/SP294

Paixão, M.A.P. Complexo ofiolítico Quatipuru, Pará, Brasil. Brasília, 2009: Instituto de Geociências, Universidade de Brasília. 118 p. (Tese de Doutorado). 
Paulsson, O., Andreasson, P.-G., 2002. Attempted break-up of Rodinia at 850 Ma: geochronological evidence from the Seve-Kalak superterrane, Scandinavian Caledonides. J. Geol. Soc. (Lond.) 159, 751-761

Peacock, S.M., Rushmer, T., Thompson, A.B., 1994. Partial melting of subducting oceaniccrust. Earth and Planetary Science Letters 121 (1-2), 227-244.

Pearce, J. A.; Harris, N. B. W.; Tindle, A. G. 1984. Trace Element Discrimination Diagrams for the Tectonic Interpretation of Granite Rocks. J. Petrology, v.25, Part 4, p.956-983.

Petford, N., Atherton, M., 1996. Na-rich partial melts from newly underplated basaltic crust: the Cordillera Blanca Batholith, Peru. Journal of Petrology 37, 1491-1521.

Pimentel, M. M.; Charnley, N.; 1991. Intracrustal REE fractionation and implications for Sm-Nd model age calculations in late-stage granitic rocks: An example from central Brazil. Chemical Geology, n.86, p.123-138. (Isotope Geoscience Section).

Pimentel, M. M.; Heaman, L..; Fuck, R. A. 1991. Zircon and sphene U-Pb geochronology of Upper Proterozoic volcanic-arc rock units from southwestern Goiás, central Brazil. Journal of South American Earth Sciences, v.4, n.94, p.295-305.

Pimentel, M. M., 1991. Late Proterozoic Crustal Evolution of the Tocantins Province in central Brazil: an Isotopic and Geochemical Study. 1991. 248 p. (PhD Thesis), University of Oxford.

Pimentel, M. M.; Fuck,R.A, 1992. Neoproterozoic crustal accretion in central Brazil. Geology, v. 20, n.4, p. 375379.

Pimentel, M. M.; Fuck, R.A ; Silva, L.J.H.D. 1996. Dados Rb-Sr e Sm-Nd da região de Jussara-GoiásMossâmedes (GO), e o limite entre terrenos antigos do Maciço de Goiás e o Arco Magmático de Goiás. Revista Brasileira de Geociências, v. 26, p. 61-70.

Pimentel, M. M., Whitehouse, M., Viana, M.G, Fuck, R.A., Machado, 1997. The Mara Rosa Arc in the Tocantins Province: further evidence for Neoproterozoic crustal accretion in Central Brazil. Precambrian Research, n.81, p.299310.

Pimentel, M. M.; Fuck, R. A.; Gioia, S. M. C. L. 1998. Novos Dados Sm-Nd e o limite leste do Arco Magmático no Sudoeste de Goiás. In: Congresso Brasileiro De Geologia, 40, Belo Horizonte. Anais... Belo Horizonte:SBG, p.39.

Pimentel, M. M.; Fuck, R.A; Jost, H.; Ferreira Filho, C.F ; Araujo, S., 2000. The basement of the Brasília Fold Belt and the Goiás Magmatic Arc. In.: Cordanni, U. G. et al. Tectonic Evolution of South América. International Geological Congress, 31, Rio de Janeiro, Anais... Rio de Janeiro, p.195-229.

Pimentel, M. M.; Botelho, N. F. 2001. Sr and Nd Isotopic characteristics of 1.77 - 1.58 Ga rift-related granites and volcanics of the Goiás Tin Province, Central Brazil. Anais da Academia Brasileira de Ciências, Brasil, v. 73, n.2, p. 263-276,.

Pimentel M. M.; Dantas, E L., Fuck, R. A.; Armstrong R.A. 2003. Shrimp and conventional U-Pb age, Sm-Nd isotopic characteristics and tectonic significance of the K-rich Itapuranga suite in Goiás, Central Brazil. An. Acad. Bras. Ciênc. vol.75, no.1. Rio de Janeiro. 
Pimentel, M.M., Jost, H., Fuck, R.A., 2004. O embasamento da Faixa Brasília e o ArcoMagmático de Goiás. In: Mantesso Neto, V., Bartorelli, A., Carneiro, C.D.R., BritoNeves, B.B. (Org.), Geologia do Continente Sul-Americano: Evoluc, ão da Obra deFernando Flávio Marques de Almeida. São Paulo, Beca Produções Culturais Ltda.pp. 355 -368.

Pimentel, M. M.; Rodrigues, J.B.; DellaGiustina, M., Emilia S.; Junges, S.; Matteini, M.; Armstrong, R., 2011. The tectonic evolution of the Neoproterozoic Brasília Belt, central Brazil, based on SHRIMP and LA-ICPMS UePb sedimentary provenance data: A review. Journal of South American Earth Sciences 31 - p.345e357

Piper, J.D.A., 1976. Paleomagnetic evidence of a Precambrian supercontinent: Philosophical Transactions Royal Society of London V. A280, p 469-490.

Piper, J.D.A., 1987. Palaeomagnetism and the Continental Crust. Open Univ Press, Milton Keynes

Piuzana, D., Pimentel, M.M., Fuck, R.A., Armstrong, R., 2003. Neoproterozoic granulite fácies metamorphism and coeval granitic magmatism in the Brasília Belt, central Brazil: regional implications of the new SHRIMP U-Pb and Sm-Nd data. Precambrian Research, 125: 245-273.

Prave, A.R., 1996. Tale of three cratons: tectonostratigraphic anatomy of the Damara orogen in northwestern Namibia and the assembly of Gondwana. Geology 24, 1115-1118.

Praxedes, I. F., 2014. Lineamento Transbrasiliano, Contribuição Aerogeofísica, Tectônica e Geocronológica no Setor Nordeste da Faixa Brasília. Dissertação de Mestrado, UnB, 84p.

Qu, X.M., Hou, Z.Q., Li, Y.G., 2004. Melt components derived from a subducted slab in late orogenic ore-bearing porphyries in the Gangdese copper belt, southern Tibetan plateau. Lithos 74, 131-148.

Ramos, V.A, 1988, Late Proterozoic-early Paleozoic of south America - A collisional history: Episodes, 11 (3): 168-174.

Rapela C.W., Pankhurst R.J., Casquet C., Baldo E., Saavedra J., Galindo C., Fanning C.M. 1998. The Pampean Orogeny of the southern proto-Andes: Cambrian continental collision in the Sierras de Cordoba. In: Pankhurst R.J., Rapela C.W., (eds.). The proto-Andean Margin of Gondwana. Geological Society of London Special Publication, 142 , p. $181-217$.

Rapp, R.P.,Watson, E.B., Miller, C.F., 1991. Partial melting of amphibolite/eclogite and the origin of Archean trondhjemites and tonalites. Precambrian Research 51, 1-25

Reginiussen, H., Ravna, E.J.K., Berglund, K., 1995. Mafic Dykes from Oksfjord, Seiland Igneous Province Northern Norway_-geochemistry and paleotectonic significance. Geol. Mag. 132, 667-681.

Ribeiro Filho, W.; Costa, J.F.G.; Araújo, V.A.; Valente, C.R.; Machado, E.C.; Matos, S.H.S.; Rodrigues, R.; Sá, A.M.; Lima, P.F.C. 1978. Projeto Geologia da região de Pilar-Mara Rosa . Relatório final. DNPM/CPRM. Goiânia (Relatório interno).

Rodrigues, J.B.; Pimentel, M.M.; Dardenne, M.A.; Armstrong, R.A., 2010. Age, provenance and tectonic setting of the Canastra and Ibiá Groups (Brasília Belt, Brazil): Implications for the age of a Neoproterozoic glacial event in central Brazil. Journal of South American Earth Sciences, v. 29, p. 512-521.

Rogers, J.J.W., 1996. A history of continents in the past 3 billion years. J. Geol. 104, 91-107. 
Rogers, J.J.W., Santosh, M., 2002. Config.tion of Columbia, a Mesoproterozoic supercontinent. Gondwana Research 5, 5-22.

Rogers, J.J.W., Santosh, M., 2004. Continents and Supercontinents. Oxford University Press, New York.

Rollinson; H.R.; Using Geochemical Data: Evaluation, presentation, Interpretation. Longman Group Limited, 351p. 1993

Rubatto D. 2002. Zircon trace element geochemistry: partitioning with garnet and the link between U-Pb ages and metamorphism. Chem. Geol., 184:123-138.

Rudnick, R.L., Gao, S., 2003. Composition of the continental crust. In: Holland, H.D., Turekian, K.K. (Eds.), Treatise on geochemistry, 3. Elsevier, Oxford, pp. 1-64.

Ruggiero, A.; Oliveira, E. P., 2010. Caracterização de vulcânicas adakíticas e cálcio-alcalinas no greenstone belt do rio Itapicuru, Bahia: Petrogênese e implicações geodinâmicas. Rev. bras. geociências vol.40 no.1 São Paulo.

Sadowski, G. R. \& Campanha, G.A C. 2004. Grandes Falhas no Brasil Continental. In: V.Mantesso Neto; A Bartorelli; C. D. R. Carneiro; B. B. B. Neves (Orgs.). Geologia do Continente Sul-Americano: Evolução da Obra de Fernando Flávio Marques de Almeida. Editora Beca, São Paulo: 407-421

Sajona, F.G., Maury, R.C., Bellon, H., Cotton, J., Defant, M.J., Pubellier, M., 1993. Initiation of subduction and the generation of slab melts in western and eastern Mindanao, Philippines. Geology 21, 1007-1010.

Sankaran, A. V.. (2003). "The supercontinent medley: Recent views". Current Science 85 (8): 1121-1123

Santosh M. A synopsis of recent conceptual models on supercontinent tectonics in relation to mantle dynamics, life evolution and surface environment. Journal of Geodynamics 50 (2010) 116-133.

Santosh, M., 2010a. Assembling North China Craton within the Columbia supercontinent: the role of double-sided subduction. Precambrian Research 178, 149-167.

Santosh, M., 2010b. A synopsis of recent conceptual models on supercontinent tectonics in relation to mantle dynamics, life evolution and surface environment. Journal of Geodynamics 50, 116-133.

Santosh, M., Zhao, G. (Eds.), 2009. Supercontinent Dynamics. Gondwana Research, 15, pp. 225-470.

Schandl. E.S. and Gorton, M.P., 2002. Application of high-field-strength elements to discriminate tectonic settings in VMS environments. Economic Geology, v. 97, No.3, p. 629-642.

Schobbenhaus, C. 1975. Carta Geológica do Brasil ao Milionésimo, Folha Goiânia - SE.22. Brasília: DNPM/Serviço Geológico Do Brasil, 74p.

Schubert, G., Masters, G., Olson, P., Tackley, P., 2004. Superplumes or plume clusters? Phys Earth Planet. Inter. $146,147-162$.

Shahabpour, J. 1997. Relantioships among the tectonic componentes of the islands arcs and their plate tectonic implications. Journal Geodynamics, Vol 23, No.2, pp 79-93.

Silva, L.J.H.D. 1990. Ouro no Grupo Cuiabá, Mato Grosso: Controles estruturais e implicações tectônicas. In: CONGR. Brás. Geol, 36. Natal, 1990. Anais... Natal, SBG. v. 6, p. 2520-2534.

Silva, M.F., Souza, J. O., Vieira, D.R., Frasca, A.A.S. 2014. Geologia e Reccursos Minerias da Folha Nova Xavantina-Placa Nativa. Serviço Geológico do Brasil. CPRM.. 
Sisson, T.W., 1994. Hornblende-melt trace-element partitioning measured by ion microprobe. Chemical Geology 117, 331-344.

Smithies, R.H., Van Kranendonk M.J, Champion, D.C., 2007. The Mesoarchean emergence of modern-style subduction. Gondwana Research 11 (2007) 50-68

Soares, j. E. P.; Berrocal, J.; Fuck, R. A.; Mooney, W.D.; Ventura, D.B.R. 2006. Seismic characteristics of central brazil crust and upper mantle: a deep seismic refraction study. Journal of geophysical research, USA, v. 111, n. b12302, p. 1029-1060.

Soares, J. E. P.; Fuck, R. A.; Berrocal, J., 2005. Estrutura da crosta do Brasil central: implicações na formação da Província Tocantins. In: IX Simpósio de Geologia do Centro-Oeste, 2005, Goiânia. Volume de resumos, v. 1. p. 128129.

Souza, J. O.\& Moreton, L. C., 1995. Geologia da Folha Xambioá Folha SB.22-Z-B (CPRM).

Souza, S. H. P. De \& Moura, C. A. V. 1996. Considerações estratigráficas sobre as rochas do embasamento do segmento meridional do Cinturão Araguaia. In.: Simpósio De Geologia Da Amazônia, 5, 1996, Belém. Atas. Belém: SBG-NO, p. 113-116.

Stacey, J.S. and Kramers, J.D. (1975). Approximation of Terrestrial Lead Isotope Evolution by a 2-Stage Model. Earth and Planetary Science Letters 26(2): 207-221.

Stein, M. and Hoffmann, A. W., Nature, 1994, 372, 63-68.

Stein, M., Goldstein, S.L., 1996. From plume head to continental lithosphere in the Arabian-Nubian shield. Nature $382,773-778$.

Stern, R.J., 1994. Arc Assembly and Continental Collision in the Neoproterozoic East-African Orogenimplications for the consolidation of Gondwanaland. Ann. Rev. Earth Planet. Sci. 22, 319-351.

Stern, C.R., Killian, R., 1996. Role of the subducted slab, mantle wedge and continental crust in the genesis of adakites from the Andean Austral Volcanic Zone. Contributions to Mineralogy and Petrology 123, 263-281.

Stern, R.J., Johnson, P.R., 2010. Continental lithosphere of the Arabian Plate: a geologic, petrologic, and geophysical synthesis. Earth-Science Reviews 101, 29-67.

Strieder, A.J.; Nilson, A. A. 1992. Estudo Petrologico de Alguns Fragmentos da Melange Ofiolitica Em Abadiania (GO): I - O Protolito dos Corpos de Serpentinito. Revista Brasileira de Geociencias, S O Paulo - Sp - Brasil, v. 22, n.3, p. 338-362.

Sun, S. and McDonough ,W. F. implications for mantle composition and processes. Chemical and isotopic systematics of oceanic basalts. Geological Society, London, Special Publications 1989; v. 42; p. 313-345.

Sun, W.D., Hu, Y.H., Kamenetsky, V.S., Eggins, S.M., Chen, M., Arculus, R.J., 2008. Constancy of Nb/U in the mantle revisited. Geochimica et Cosmochimica Acta 72, 3542-3549.

Taylor, S.R., McLennan, S.M., 1985. The continental crust: its composition and evolution.

Teixeira, N. Assoalho oceânico no complexo ultramáfico do Quatipuru (PA). Implicações Geotectônicas para a faixa móvel Araguaia1996. Congresso Brasileiro De Geologia, 39, V.6, p. 117-120. 
Tharp, M. B., Heezen C., Ewing, M., 1959. The Floors of the Ocean. Geological Society of America Special Paper 65. New York: Geological Society of America.

Thorkelson, D.J. 2000. Geology and mineral occurrences of the Slats Creek, Fairchild Lake and "Dolores Creek" areas Wernecke Mountains, Yukon (106D/16, 106C/13, 106C/14). Indian and Northern Affairs Canada, Exploration and Geological Services Division, Bulletin 10, 73 p.

Thorkelson, D.J., Breitsprecher, K., 2005. Partial melting of slab window margins: genesis of adakitic and nonadakitic magmas. Lithos 79 (1-2), 25-41.

Tohver, Eric ; D'agrella filho, Manoel de Souza ; Trindade, R. I. F. . Paleomagnetic record of Africa and South America for the 1200-500 Ma interval, and evaluation of Rodinia and Gondwana assemblies. Precambrian Research, v. 147, p. 193-222, 2006.

Titley, S.R., and Beane, R.E., 1981, Porphyry copper deposits-Part I: Geologic settings, petrology, and tectogenesis: Economic Geology, 75th anniversary volume, p. 214-235.

Torsvik, T.H., 2003. The Rodinia jigsaw puzzle. Science 300, 1379-1381.

Trindade, C. R., Soares, J. E. P., Fuck, R. A., Carmelo, A. C., Peixoto, C. L. O. 2014. Estrutura crustal do Brasil central. In: $2^{\circ}$ Congresso de Geologia da Língua Portuguesa, Porto. Anais $2^{\circ}$ p. 76.

Trompette R. 1994. Geology of Western Gondwana (2000-500 Ma). Pan-African-Brasiliano aggregation of South America and Africa. A.A. Balkema, Rotterdam, 350 pp.

Trouw R. A. J., Vaz, L. F., Slongo, T. T., Nakasato, N. (1976). Geologia da região de Tucuruí, Baixo Tocantins, Pará. In: Congresso Brasileiro de Geologia, Ouro Preto p. 20-31.

Tupinambá. M., Teixeira, Heilbron M., 2012. Tectonic and magmatic evolution of the Ribeira Belt in the Highlands of the Rio de Janeiro State, Brazil, from Neoproterozoic to Lower Paleozoic. Anuário do Instituto de Geociências - UFRJ ISSN 0101-9759 e-ISSN 1982-3908 - Vol. 35 - 2 / 2012 p.140-151

Unrug R. 1992. The supercontinental cycle and Gondwanaland assembly: component cratons and the timing of suturing events. Journal of Geodynamics, 16, 215-240.

Valentine J.W., Moores, E.M. Plate tectonic regulation of faunal diversity and sea level • Nature, 228 (1970), pp. $657-659$

Valeriano, C. M. ; Dardenne, M. A. ; Fonseca, M.A. ; Simões, Amarante, L. S. ; SEER, H.J. 2004. A Evolução Tectônica da Faixa Brasília. In: Mantesso Neto V.; Bartorelli A.; Carneiro, C. D. R.; Brito Neves, B. B.. (Org.). Geologia do Continente Sul-Americano - Evolução da obra de Fernando Flávio Marques de Almeida. São Paulo: Beca, v. , p. 575-592.

Valeriano, C. M. ; Pimentel, M. M. ; Heilbron, M. ; Almeida, J. C. H. ; Trouw, R. A. J. 2008. Tectonic evolution of the Brasilia Belt, Central Brazil, and early assembly of Gondwana. Geological Society Special Publication, v. 294, p. 197-210.

Vauchez, A. e Nicolas, A. (1991). Mountain building: strike parallel motion and mantle anysotropy. Tectonophysics, $185-$ p183-201. 
Ventura D. B R; Soares, J. E.; Fuck R. A.; Coutrim, C. L. C.; 2011. Caracterização sísmica e gravimétrica da litosfera sob a linha de refração sísmica profunda de Porangatu, Província Tocantins, Brasil Central. Revista Brasileira de Geociências, 41(1): 130-140.

Wang, Q., et al., 2004. Cretaceous high-potassium intrusive rocks in the Yueshan- Hongzhen area of east China: adakites in an extensional tectonic regime within a continent. Geochemical Journal 38, 417-434.

Wang, Q., Xu, J., Jian, P., Bao, Z., Zhao, Z., Li, C., Xiong, X., Ma, J., 2006. Petrogenesis of adakitic porphyries in an extensional tectonic setting, Dexing, south China: implications for the genesis of porphyry copper mineralization. Journal of Petrology 47, 119-144.

Wang, Q.,McDermott, F., Xu, J.-F., Bellon, H., Zhu, Y.-T., 2005. Cenozoic K-rich adakitic volcanic rocks in the Hohxil area, northern Tibet: Lower-crustal melting in an intracontinental setting. Geology 33, 465-468.

Watson E B \& Harrison M.,1983. Zircon saturation revisited: temperature and composition effects in a variety of crustal magma types. Earth Planet Sci Lett 64: 295-304.

Wilson, J.T. 1965. Evidence from ocean islands suggesting movement in the Earth. Philosophical Transactions of the Royal Society A 258, 145-167Windley (1983)

Windley (1986) The continental crust: its composition and evolution: S.R. Taylor and S.M. McLennan. Blackwell, 1985. xv + 312 pp., £16.80, ISBN 0-632-01148-3 Physics of the Earth and Planetary Interiors, Volume 42, Issue 3, 28 February 1986, Pages 196-197

Winter (1996). An experimentally based model for the origin of tonalitic and trondhjemitic melts. Chemical Geology $127,43-59$.

Worsley, T.R., Nance, R.D., Moody, J.B., 1982. Plate tectonic episodicity: a deterministic model for periodic "Pangeas". Eos, Transactions of the American Geophysical Union 65 (45), 1104.

Worsley, T.R., Nance, R.D., Moody, J.B., 1984. Global tectonics and eustasy for the past 2 billion years. Marine Geology 58, 373-400.

Xu, H., Ma, C., Zhang, J., 2012. Generation of Early Cretaceous high-Mg adakitic host and enclaves by magma mixing, Dabie orogen, Eastern China. Lithos 142-143, 182-200.

Xu, W.-L., Wang, Q.-H., Wang, D.-Y., Guo, J.-H., Pei, F.-P., 2006. Mesozoic adakitic rocks from the XuzhouSuzhou area, eastern China: evidence for partial melting of delaminated lower continental crust. Journal of Asian Earth Sciences 27, 230-240.

Yoshida, M., Santosh, M., 2011a. Supercontinents, mantle dynamics and plate tectonics: a perspective based on conceptual vs. numerical models. Earth-Science Reviews 105, 1-24.

Zakariadze. G.S., Dilek Y., Adamia, S.A., Oberhänsli, R.E., Karpenko, S.F., Bazylev B.A., Solov'eva N., 2007. Geochemistry and geochronology of the Neoproterozoic Pan-African Transcaucasian Massif (Republic of Georgia) and implications for island arc evolution of the late Precambrian Arabian-Nubian Shield. Gondwana Research 11- 92-108

Zhao,D. 2001; The Present Three Dimensional Images of the Earth's Mantle. Gondwana Research, Volume 4, Issue 4, October, Page 841. 
Zhao, J.H., Zhou, M.F., 2008. Neoproterozoic adakitic plutons in the northern margin of the Yangtze Block, China: partial melting of a thickened lower crust and implications for secular crustal evolution. Lithos 104, 231-248.

Zhao, Z.H., Xiong, X.L., Wang, Q., Wyman, D.A., Bao, Z.W., Bai, Z.H., Qiao, Y.L., 2008. Underplating-related adakites in Xinjiang Tianshan, China. Lithos 102, 374-391. 